SAMUEL CAMPANELLI FREITAS COUTO

\title{
INLUÊNCIA DOS SISTEMAS DE QUORUM SENSING AI-1/AI- 2/AI-3 NOS FATORES DE VIRULÊNCIA DE EPEC ATÍPICA DE ORIGEM ANIMAL
} Tese apresentada ao Programa de
Pós-Graduação Interunidades em
Biotecnologia da Universidade de São
Paulo, Instituto Butantan e Instituto de
Pesquisas Tecnológicas para
obtenção do Título de Doutor em
Biotecnologia. 


\title{
SAMUEL CAMPANELLI FREITAS COUTO
}

\section{INFLUÊNCIA DOS SISTEMAS DE QUORUM SENSING AI-1/AI- 2/AI-3 NOS FATORES DE VIRULÊNCIA DE EPEC ATÍPICA DE ORIGEM ANIMAL}

\begin{abstract}
Tese apresentada ao Programa de Pós-Graduação Interunidades em Biotecnologia da Universidade de São Paulo, Instituto Butantan e Instituto de Pesquisas Tecnológicas para obtenção do Título de Doutor em Biotecnologia.
\end{abstract}

Área de Concentração: Biotecnologia

Orientador: Prof. Dr. Marcelo Palma Sircili Coorientadora: Dra. Vanessa Bueris

Versão Original 


\section{CATALOGAÇÃO NA PUBLICAÇÃO (CIP) \\ Serviço de Biblioteca e informação Biomédica \\ do Instituto de Ciências Biomédicas da Universidade de São Paulo}

Ficha Catalográfica elaborada pelo(a) autor(a)

Campanelli Freitas Couto, Samuel

Influência dos Sistemas de Quorum sensing AI-

1/AI-2/AI-3 nos fatores de virulência de EPEC atípica de origem animal / Samuel Campanelli Freitas Couto; orientadora Marcelo Palma Sircili; coorientadora Vanessa Bueris. -- São Paulo, 2018.

$151 \mathrm{p}$.

Tese (Doutorado)) -- Universidade de São Paulo, Instituto de Ciências Biomédicas.

1. Escherichia coli. 2. Quorum Sensing. 3. Biofilme. 4. Regulação Gênica. 5. Patogênese. I. Palma Sircili, Marcelo, orientador. II. Bueris, Vanessa, coorientador. III. Título. 


\section{UNIVERSIDADE DE SÃO PAULO \\ Programa de Pós-Graduação Interunidades em Biotecnologia \\ Universidade de São Paulo, Instituto Butantan, Instituto de Pesquisas Tecnológicas}

Candidato(a): Samuel Campanelli Freitas Couto

Titulo da Tese: Influência dos sistemas de Quorum Sensing AI-1/AI2/AI-3 nos fatores de virulência de EPEC atípica de origem animal

Orientador: Prof. Dr. Marcelo Palma Sircilo

Coorientadora: Dra. Vanessa Bueris

A Comissão Julgadora dos trabalhos de Defesa da Tese de Doutorado, em sessão pública realizada a considerou o(a) candidato(a):

\section{( ) Aprovado(a) ( ) Reprovado(a)}

Examinador(a): $\quad$ Assinatura:

Nome:

Instituição:

Examinador(a): $\quad$ Assinatura:

Nome:

Instituição:

Examinador(a): $\quad$ Assinatura:

Nome:

Instituição:

Examinador(a): $\quad$ Assinatura:

Nome:

Instituição:

Examinador(a): $\quad$ Assinatura:

Nome:

Instituição:

Presidente: Assinatura: 
IImo(a). Sr(a).

Responsável: Dr. Marcelo Palma Sircili

Área: Biotecnologia

Equipe envolvida: Samuel Campanelli Freitas Couto - executor (instituto Butantan - Usp); Dr. Marcelo Palma Sircili (orientador)

Título do projeto: "Influência dos sistemas de Quorum Sensing Al-1/AI-2/AI-3 nos fatores de virulência de EPEC atípica de origem animal".

\section{Parecer Consubstanciado da CEUA IB}

A Comissão de Ética no Uso de Animais da Instituto Butantan, na reunião de 16/05/2018, ANALISOU e APROVOU o protocolo de estudo acima referenciado. A partir desta data, é dever do pesquisador:

1. Comunicar toda e qualquer alteração do protocolo.

2. Comunicar imediatamente ao Comitê qualquer evento adverso ocorrido durante o desenvolvimento do protocolo.

3. Os dados individuais de todas as etapas da pesquisa devem ser mantidos em local seguro por 5 anos para possível auditoria dos órgãos competentes.

4. Relatórios parciais de andamento deverão ser enviados anualmente à CEUA até a conclusão do protocolo.

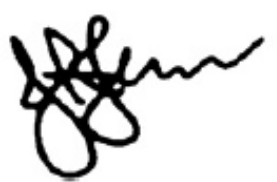

Jose Ricardo Jensen

Coordenador da Comissão de Ética no Uso de Animais Instituto Butantan

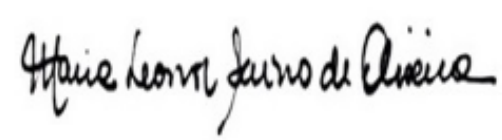

Maria Leonor Sarno de Oliveira Vice-Coordenadora da Comissão de Ética no Uso de Animais Instituto Butantan 
Dedico este trabalho aos meus pais, Maria Elisa e Marco Antônio, por todo amor, confiança e atenção investidos em mim. Sou grato aos dois por tudo que sou e almejo ser. 


\section{AGRADECIMENTOS}

À Dra. Vanessa Bueris, pela orientação, amizade e paciência. Este trabalho não teria sido realizado sem a sua ajuda fundamental, desde os ensinamentos práticos aos conhecimentos teóricos. Obrigado por me acolher e transmitir parte do seu vasto conhecimento em ciência. Tenho certeza que vamos continuar nos conhecendo na vida pós-Butantan.

Ao Dr. Marcelo Palma Sircili, por me aceitar como aluno em seu laboratório e oferecer uma oportunidade de trabalhar com ciência mesmo sem ter tido experiência na área. Agradeço por sempre ter me dado liberdade para trabalhar e pelas críticas sinceras mas necessárias. Sempre que precisar de alguém para te sinalizar que está passando do limite pode contar comigo.

Ao Dr. Renato Ruiz, por me "apadrinhar" quando entrei no laboratório e me ensinar muito do que sei hoje. Sua amizade vai além da bancada, das cervejas nos bares e dos shows de Rock. Sei que posso contar sempre com você, e vice-versa.

Ao Dr. Hebert Fabrício Culler, por ser uma das pessoas mais autênticas e modestas que já conheci, além de ser um excelente amigo e colega de trabalho. Se um dia souber só um pouco de tudo que você sabe me darei por satisfeito.

À Larissa, conterrânea nordestina, abestada, amiga para a vida inteira. Quando não estava me ajudando no laboratório estava sempre me acompanhando nas idas ao CEPE para nadar, correr, ser torturada nas abdominais e conversar sobre o que fosse.

À Juliana Higa (amor), pela amizade, parceria em shows e trabalhos para tirar uma grana extra. No fundo desse coração peludo existe uma pessoa sensível e 
simpática.

À Isabella, por ser minha parceira no crime durante o PAP e me ensinar muito da vida com sua esperteza mineira.

À Min, pela amizade, ajuda no trabalho e por cozinhar doces apetitosos para aguentar um dia inteiro de laboratório.

Às meninas do Laboratório de Bacteriologia, Fernanda, Claudia, Lídia, Dani Luz e Munhoz. Irmãzinha Matilde pelo carinho e amizade, e Ludmila por sempre me receber com um sorriso no rosto e bom humor. Aos antigos alunos da Bac, Bruno e Fernando.

Aos colegas do Laboratório de Genética, Jacqueline, Araldi e Rodrigo.

À Dra. Márcia Franzolin, por sempre estar disposta a ajudar.

Ao Alecsander Seixas de Souza, pela amizade, os papos "nerd" e, claro, pela captura de imagens de Microscopia Confocal.

Aos pesquisadores do Instituto Butantan, Dra. Rita de Cássia Stocco, Dr. Waldir Elias Pereira e Dra. Roxane Piazza.

Aos funcionários do Laboratório, Youko pela imensa ajuda no preparo de meios de cultura, por conseguir materiais e reagentes para o laboratório, pelo café pós-preendial essencial e por sempre ser simpática. Ivone e Rose por toda ajuda prestada.

Ao Marcos, por ter me feito uma pessoa melhor desde o dia em que o conheci. Acredito que continuará me incentivando a ser o melhor de mim pelo resto de nossas vidas. 
Aos meus irmãos Carolina e Rúben, por terem me tratado como um irmão de sangue mesmo sendo filho da luda.

Aos grandes amigos e padrinhos Marco e Ellen, por ajudar a manter minha sanidade mental com nossos jogos de buraco semanais obrigatórios.

Às três pessoas que me ajudaram a suportar a época de escola e agora me ajudam a levar a vida, Biló, Lólis e Faffles.

Aos amigos de faculdade Babi e Carioca, que se tornaram amigos para a vida toda.

Aos amigos de infância, Konga, Netto, Rodrigo, Thiago, Milene, Natália.

Ao meu primo e parceiro de banda Eduardo (Bagel).

À minha grande família, avós, avô, tios, tias e primos queridos.

À CAPES pela bolsa de auxílio.

E à todos aqueles que, direta ou indiretamente, participaram e colaboraram para a realização deste trabalho. 
"For within a man there is light, and if he lets that light shine, he lights up the entire world, and if he doesn't, he lives in total darkness."

Gospel of Thomas 


\section{RESUMO}

COUTO, S. C. F. Influência dos sistemas de Quorum Sensing Al-1/AI-2/AI-3 nos fatores de virulência de EPEC atípica de origem animal. 2018. $151 \mathrm{f}$. Tese (Doutorado em Biotecnologia) - Instituto de Ciências Biomédicas, Universidade de São Paulo, São Paulo.

A secreção de moléculas sinalizadoras de baixo peso molecular que se acumulam no meio extracelular até atingir um limite crítico de concentração para sua detecção, acarretando em sinalizações intracelulares e respostas efetoras, define o sistema de comunicação bacteriano chamado Quorum Sensing. Este sistema, que regula comportamentos coletivos mostrou-se um mecanismo disseminado em diversas espécies bacterianas. Diversos estudos descreveram a existência de pelo menos 3 sistemas relacionados ao Quorum Sensing em bactérias Gram-negativas, LuxIR/AI-1, LuxS/AI-2 e QseBC/AI3/Epinefrina/Norepinefrina. Fatores de virulência como formação de biofilme, motilidade e adesão ao epitélio do hospedeiro devem ser controlados de maneira adequada para tirar o melhor proveito da situação em que a bactéria se encontra. Este trabalho teve como objetivo analisar a influência e a correlação dos genes luxS, qseC e sdiA, relacionados ao sistema de comunicação bacteriana Quorum Sensing, nos principais fatores de virulência de uma amostra de EPEC atípica de origem animal. Foram construídos mutantes pela metodologia baseada na recombinação homóloga mediada pelo sistema Lambda Red, que foram submetidos a ensaios fenotípicos. A sinalização por AI-2 e luxS desempenham papéis na motilidade, formação de biofilme e adesão a células epiteliais. QseC influencia a produção de biofilme pela regulação de componentes da matriz extracelular, e participa de processos de motilidade e adesão. O hormônio epinefrina contribui na alteração de processos de motilidade, formação de biofilme e desenvolvimento da lesão A/E. O gene sdiA também tem um papel importante na regulação de fatores de virulência, mesmo na ausência de AHL. Uma interação antagônica parece existir entre os genes qseC e luxS. A ausência de sistemas de Quorum Sensing promove a produção de um biofilme robusto na amostra AP155.

Pavras-chave: Escherichia coli. Quorum Sensing. Biofilme. Regulação Gênica. Patogênese 


\section{ABSTRACT}

COUTO, S. C. F. Influence of Quorum Sensing systems Al-1/AI-2/AI-3 on the virulence factors of atypical EPEC isolated from an animal. 2018. $151 \mathrm{p}$. Ph. D. Thesis (Doctor in Biotechnology) - Instituto de Ciências Biomédicas da Universidade de São Paulo, São Paulo.

The secretion of low molecular weight signaling molecules that accumulate in the extracellular medium until reaching a critical concentration limit for its detection, leading to intracellular signaling and effector responses, defines the bacterial communication system called Quorum Sensing. This system regulates collective behaviors and has been proven to be a widespread mechanism in several bacterial species. Several studies have described the existence of at least 3 Quorum Sensing-related systems in Gram-negative bacteria, LuxIR/AI-1, LuxS/AI-2 and QseBC/AI-3/Epinephrine/Norepinephrine. Virulence factors such as biofilm formation, motility and adhesion to the host epithelium should be adequately regulated to make the most of the situation in which the bacterium is found. The aim of this work was to analyze the influence and correlation of luxS, qseC and sdiA genes, related to the bacterial communication system Quorum Sensing, on the main virulence factors of an atypical EPEC strain isolated from an animal. Mutants were obtained through homologous recombination mediated by the Lambda Red system, and then were submitted to phenotypic assays. Al2 signaling and luxS play roles in motility, biofilm formation, and adhesion to epithelial cells. QseC influences the production of biofilm by the regulation of components of the extracellular matrix, and participates in the processes of motility and adhesion as well. The epinephrine hormone alters the processes of motility, biofilm formation and development of the A/E lesion. The sdiA gene also plays an important role in the regulation of virulence factors, even in the absence of AHL. An antagonistic interaction seems to exist between the qseC and luxS genes. The absence of Quorum Sensing systems promotes the production of a robust biofilm in the AP155 strain.

Keywords: Escherichia coli. Quorum Sensing. Biofilm. Gene Regulation. Pathonesis. 


\section{LISTA DE ILUSTRAÇÕES}

Figura 1. Extração dos plasmídeos acessórios do sistema Lambda Red. 69

Figura 2. Amplificação do cassete de recombinação cat. 69

Figura 3. Detecção da deleção dos genes luxS, qseC e sdiA por eletroforese em gel de agarose $1 \%$

Figura 4. Detecção da deleção do duplo mutante e triplo mutante eletroforese em gel de agarose $1 \%$.

Figura 5. Curva de crescimento em meio LB das amostras AP155 selvagem e mutantes.

Figura 6. Ensaio de motilidade em ágar semi-sólido (0,3\%) das amostras AP155 selvagem e mutantes.

Figura 7. Ensaio de motilidade em ágar semi-sólido (0,3\%) das amostras AP155 selvagem e mutantes na presença de moléculas autoindutoras.

Figura 8. Produção de fímbria curli em placas Vermelho Congo das amostras AP155 selvagem e mutantes.

Figura 9. Produção de celulose das amostras AP155 selvagem

e mutantes, em placas contendo Calcofluor.

Figura 10. Formação de biofilme em placas de poliestireno pelas amostras AP155 selvagem e mutantes, após $24 \mathrm{~h}$ de incubação em LB.

Figura 11. Formação de biofilme em placas de poliestireno após $24 \mathrm{~h}$ de incubação em LB suplementado com moléculas autoindutoras.

Figura 12. Formação de biofilme em lamínulas de vidro pela amostra selvagem após $24 \mathrm{~h}$ de incubação em LB suplementado com moléculas autoindutoras.

Figura 13. Formação de biofilme em lamínulas de vidro pela amostra $\Delta l u x S$ e $\Delta / u x S^{+}$ após $24 \mathrm{~h}$ de incubação na presença e ausência de moléculas autoindutoras.

Figura 14. Formação de biofilme em lamínulas de vidro pela amostra $\Delta q s e C$ e $\Delta q s e C^{+}$ após $24 \mathrm{~h}$ de incubação na presença e ausência de moléculas autoindutoras.

Figura 15. Formação de biofilme em lamínulas de vidro pela amostra $\Delta s d i A$ e $\Delta s d i A^{+}$ após $24 \mathrm{~h}$ de incubação na presença e ausência de moléculas autoindutoras.

Figura 16. Formação de biofilme em lamínulas de vidro pela amostra duplo mutante após $24 \mathrm{~h}$ de incubação na presença e ausência de moléculas autoindutoras.

Figura 17. Formação de biofilme em lamínulas de vidro pela amostra triplo mutante após $24 \mathrm{~h}$ de incubação na presença e ausência de moléculas autoindutoras.

Figura 18. Interação da amostra selvagem com células HeLa na presença e ausência de moléculas autoindutoras.

Figura 19. Interação das amostras $\Delta l u x S$ e $\Delta l u x S^{+}$com células HeLa na presença e ausência de moléculas autoindutoras.

Figura 20. Interação das amostras $\Delta q s e C$ e $\Delta q s e C^{+}$com células HeLa na presença e ausência de moléculas autoindutoras. 
Figura 21. Interação das amostras $\Delta s d i A$ e $\Delta s d i A^{+}$com células HeLa na presença e ausência de moléculas autoindutoras.

Figura 22. Interação da amostra duplo mutante com células HeLa na presença e ausência de moléculas autoindutoras.

Figura 23. Interação da amostra triplo mutante com células HeLa na presença e ausência de moléculas autoindutoras.

Figura 24. Controle dos ensaios de interação com células HeLa na presença de DMSO.

Figura 25. Controles celulares dos ensaios de interação com células HeLa na presença e ausência de autoindutores.

Figura 26. Quantificação da adesão da amostra selvagem e mutantes na presença e ausência de Al-2.

Figura 27. Quantificação da adesão da amostra selvagem e mutantes na presença e ausência de Epi.

Figura 28. Quantificação da adesão da amostra selvagem e mutantes na presença e ausência de Al-1.

Figura 29. Análise da formação da lesão A/E pela amostra selvagem na presença e ausência de autoindutores.

Figura 30. Análise da formação da lesão A/E pelas amostras $\Delta / u x S$ e $\Delta / u x S^{+}$ na presença e ausência de autoindutores.

Figura 31. Análise da formação da lesão A/E pelas amostras $\Delta q s e C$ e $\Delta q s e C^{+}$ na presença e ausência de autoindutores.

Figura 32. Análise da formação da lesão $\mathrm{A} / \mathrm{E}$ pelas amostras $\Delta s d i A$ e $\Delta s d i A^{+}$ na presença e ausência de autoindutores.

Figura 33. Análise da formação da lesão A/E pela amostra duplo mutante na presença e ausência de autoindutores.

Figura 34. Análise da formação da lesão A/E pela amostra triplo mutante na presença e ausência de autoindutores.

Figura 35. Análise transcricional dos principais genes envolvidos na formação de biofilme (fliC, bcsA, $\operatorname{csg} D, \operatorname{csg} A)$.

Figura 36. Análise transcricional dos principais genes envolvidos na formação da lesão A/E (fimA, ler, eae, espA).

Figura 37. Análise transcricional dos principais genes envolvidos na regulação por Quorum Sensing em E. coli (luxS, qseC, sdiA).... 


\section{LISTA DE TABELAS}

Tabela 1 - Linhagens bacterianas e plasmídeos utilizados.

Tabela 2 - Sequência dos iniciadores utilizados neste estudo, ciclos de amplificação e tamanho dos fragmentos obtidos em cada reação.

60

Tabela 3 - Iniciadores utilizados nas reações de qRT-PCR. 66 


\section{SUMÁRIO}

1 INTRODUÇÃO

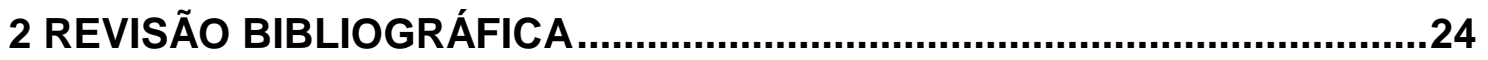

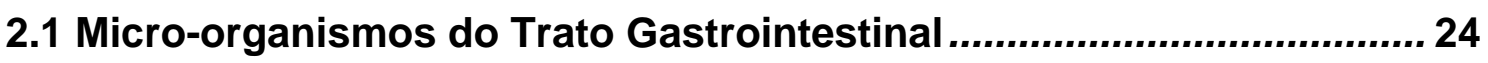

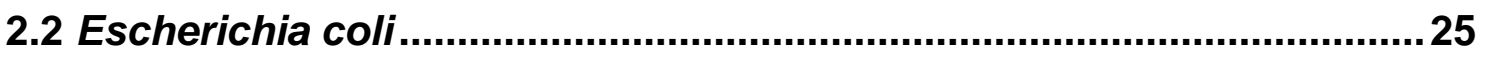

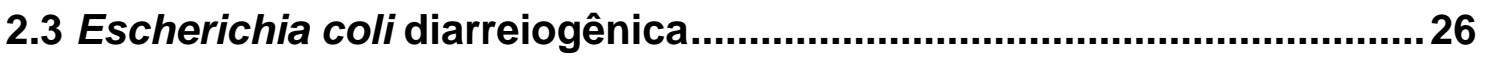

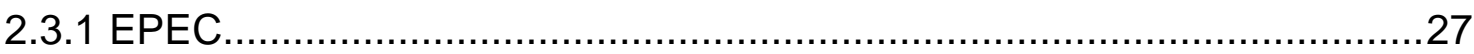

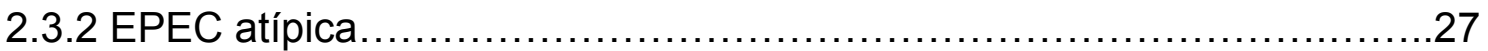

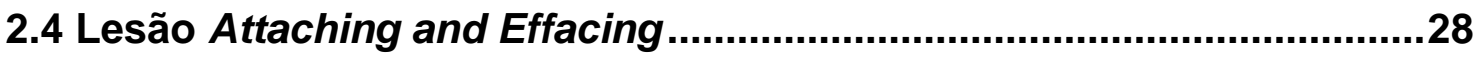

2.5 Epidemiologia e relação com diarreias infecciosas..............................29

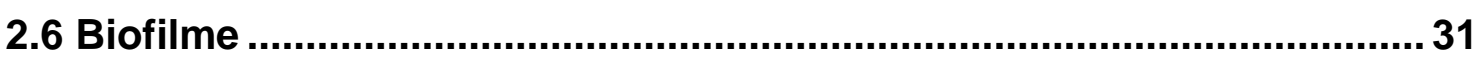

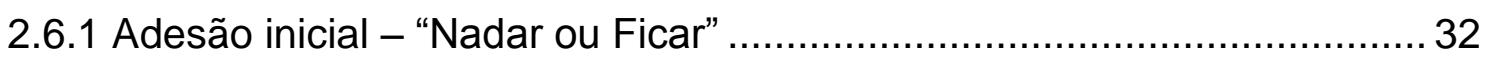

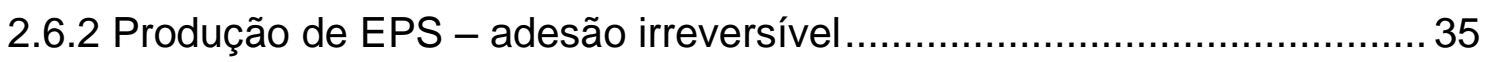

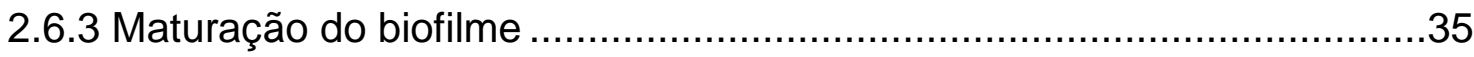

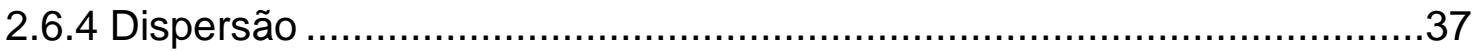

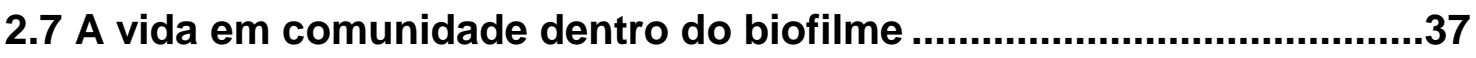

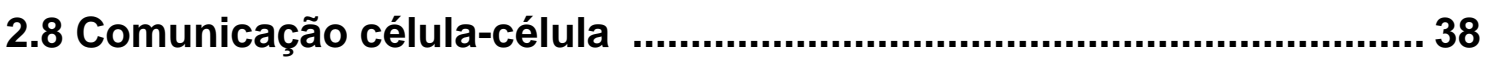

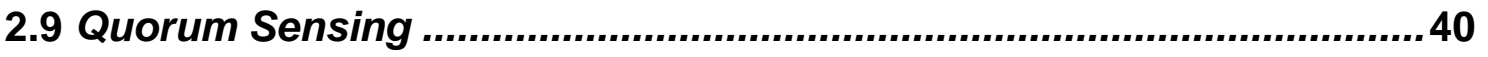

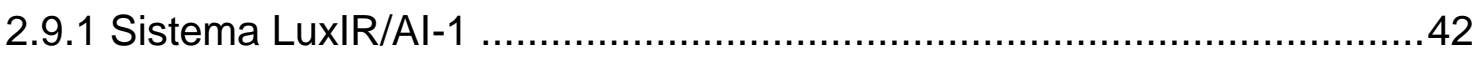

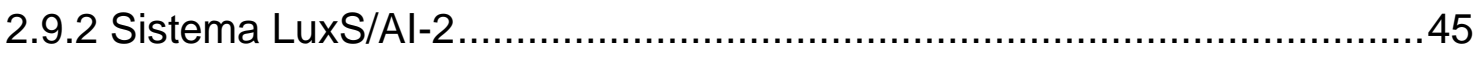

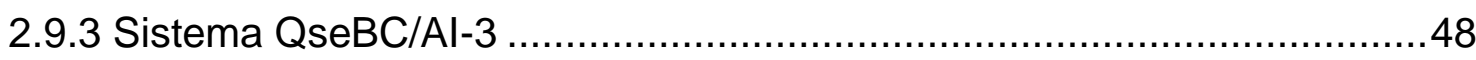

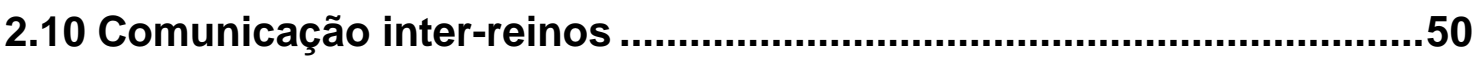

2.11 Quorum Sensing em E. coli.................................................................51

3 OBJETIVOS

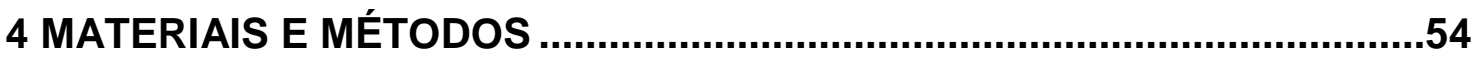

4.1 Amostras bacterianas e plasmideos .......................................................54

4.2 Meios de cultura e soluções..............................................................54

4.3 Detecção dos genes luxS, qseC e sdiA.................................................56

4.3.1 Reacções em Cadeia da Polimerase (PCR) …………………..........56

4.3.2 Eletroforese de DNA em gel de agarose .............................................56 
4.3.3 Purificação dos fragmentos

4.4 Obtenção de mutantes em luxS, qseC e sdiA...................................57

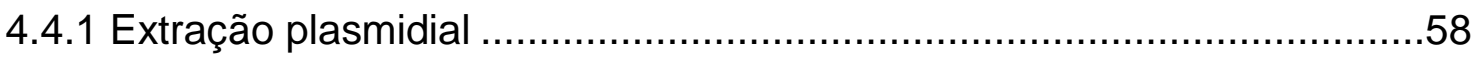

4.4.2 Obtenção de células eletrocompetentes .......................................58

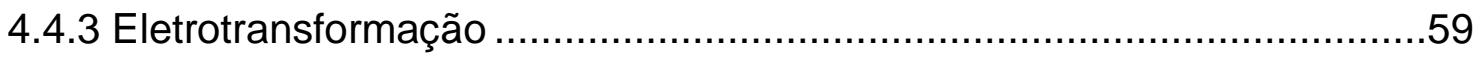

4.4.4 Confirmação da mutação .......................................................59

4.5 Curvas de Crescimento .........................................................................61

4.6 Ensaios de interação com células epiteliais in vitro............................61

4.6.1 Adesão bacteriana em células epiteliais........................................61

4.6.2 Quantificação de bactérias aderidas a células epiteliais ........................62

4.6.3 Teste de FAS (Fluorescent actin staining) .........................................62

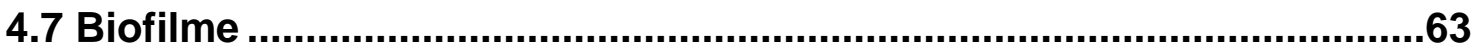

4.7.1 Ensaios de formação de biofilme - Cristal Violeta ................................63

4.7.2 Visualização da formação de biofilme através de

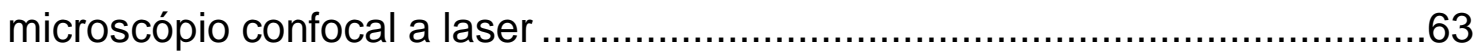

4.7.3 Ensaio de produção de cellulose e fímbria curli ................................64

4.8 Teste de motilidade em placa de agar semi-sólido .............................64

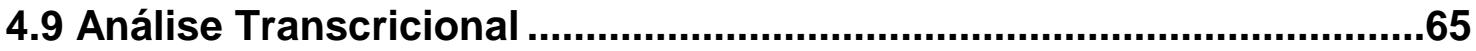

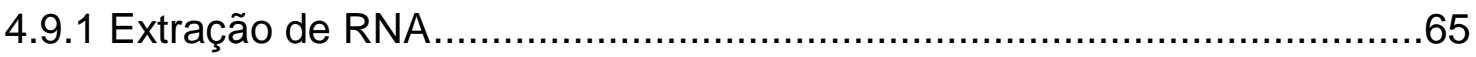

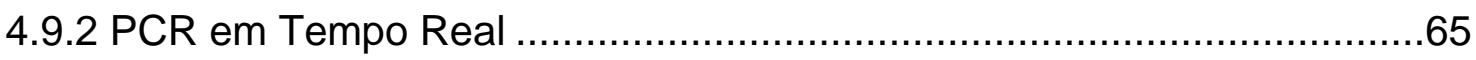

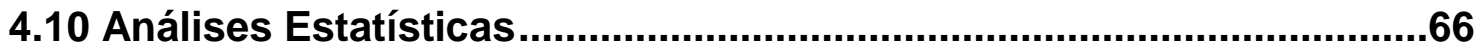

5 RESULTADOS...........................................................................................67

5.1 Obtenção dos mutantes nos genes qseC, sdiA,

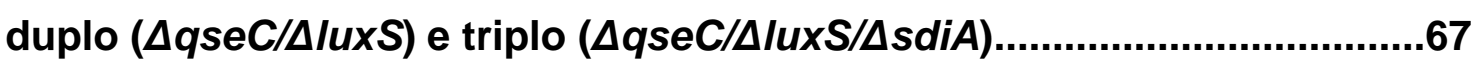

5.2 Complementação das amostras mutantes..........................................68

5.3 Curvas de crescimento das amostras selvagens, mutantes e complementadas .................................................................. 71

5.4 Ensaio de motilidade em ágar semi-sólido ...........................................71

5.5 Expressão de fímbria curli................................................................... 75

5.6 Produção de celulose ........................................................................ 76

5.7 Formação de biofilme em superfície abiótica .................................... 76 


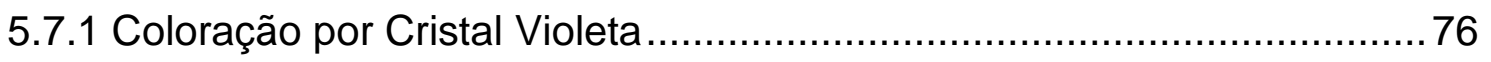

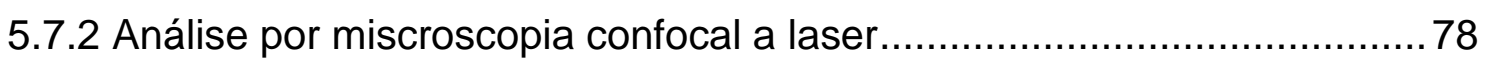

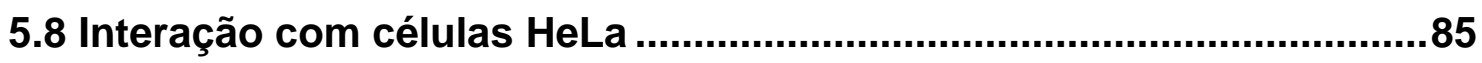

5.8.1 Adesão bacteriana em células epiteliais.............................................. 85

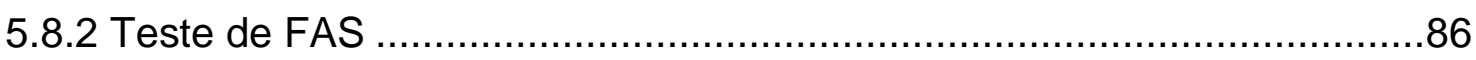

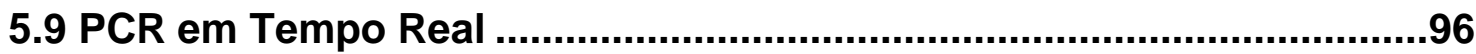

6 DISCUSSÃO

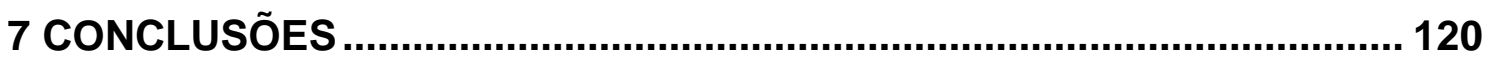

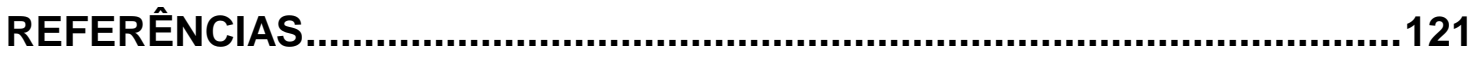




\section{INTRODUÇÃO}

Escherichia coli é uma bactéria facultativa pertencente à família Enterobacteriaceae e é um componente da microbiota intestinal humana e de outros animais. Alguns clones específicos de E. coli causam infecções intestinais quando alcançam esse sítio anatômico. Essas amostras são chamadas de $E$. coli diarreiogênicas ou DEC (NATARO, KAPER, 1998).

A diarreia é uma das causas de morte mais comum em crianças e recémnascidos em países em desenvolvimento (NAKHJAVANI et al., 2013) e estima-se que patótipos de E. coli estejam envolvidos em até $50 \%$ dos casos relatados (CHANDRA et al., 2012).

As amostras de E. coli associadas à infecção intestinal, tanto em crianças como em adultos, são classificadas em seis patótipos ou categorias, considerando os seus mecanismos de virulência específicos, os sorotipos $\mathrm{O}: \mathrm{H}$, os aspectos epidemiológicos e/ou os tipos de interação com linhagens celulares in vitro (NATARO, KAPER, 1998). Esses patótipos de DEC são: E. coli enteropatogênica (EPEC), E. coli enterotoxigênica (ETEC), E. coli enteroinvasora (EIEC), E. coli enterohemorrágica (EHEC), E. coli enteroagregativa (EAEC) e E. coli que adere difusamente a células epiteliais (DAEC) (NATARO, KAPER, 1998). Embora essa classificação continue sendo usada pela maioria dos autores, torna-se evidente que algumas categorias incluem micro-organismos bastante diferentes. Desta forma, as EPEC e EAEC foram subdivididas em típicas e atípicas e as EHEC passaram a constituir uma subcategoria de STEC, ou, E. coli produtora da toxina de Shiga (KAPER et al., 2004).

Como citado anteriormente, EPEC pode ser classificada em típica (tEPEC) e atípica (aEPEC). O termo aEPEC foi criado em 1995 para denominar amostras de $E$. coli que se distinguem das tEPEC por não transportarem o plasmídeo EAF (EPEC adherence factor) (BALDINI et al., 1983), e das EHEC, por não produzirem a toxina Stx (KAPER, 1996). O plasmídeo EAF contém os genes envolvidos na biogênese de uma adesina fimbrial denominada bundle-forming pilus (BFP), que confere a característica de adesão localizada de EPEC à célula hospedeira (GIRÓN et al., 1991). Diferente das tEPEC, as aEPEC podem aderir ou não às células epiteliais in vitro. As amostras aderentes expressam predominantemente o padrão localizadolike ( $\mathrm{LAL}$ ), no qual as bactérias apresentam-se aderidas em pontos isolados da 
célula epitelial formando microcolônias frouxas, o que é evidenciado após períodos prolongados de interação bactéria-célula epitelial (RODRIGUES et al., 1996; PELAYO et al., 1999; SCALETSKY et al., 1999, BUERIS et al., 2015). Além do padrão LAL, os padrões adesão agregativa (AA) (DO VALLE et al., 1997; BARROS et al., 2008) e adesão difusa (AD) (TRABULSI et al., 2002) também são expressos por amostras de aEPEC.

A principal característica de tEPEC e aEPEC com padrão de adesão ALL é a capacidade de causar a lesão histopatológica denominada attaching-effacing (lesão $A / E)$. A lesão $A / E$ ocorre pela ação coordenada de genes codificados em uma ilha de patogenicidade (IPA) denominada região LEE (locus of enterocyte effacement). Histologicamente, a lesão é caracterizada pela destruição das microvilosidades intestinais, aderência íntima da bactéria à membrana apical da célula epitelial e formação de estruturas celulares semelhantes a pedestais (MOON et al., 1983). Entre outros fatores, a região LEE é regulada por Quorum Sensing, um processo de sinalização celular baseado na produção e detecção de moléculas denominadas autoindutores (Al) (SPERANDIO et al., 1999; SIRCILI et al., 2004; LENZ et al., 2005; NOVAK et al., 2010).

Amostras de aEPEC são responsáveis por um grande número de casos de diarreia em crianças em diversos países em desenvolvimento e, no Brasil, foram isoladas em casos de diarreia aguda (ORLANDI et al., 2006; BUERIS et al., 2007; ABBA et al., 2009; ARENAS-HERNÁNDEZ et al., 2012;, CONTRERAS et al., 2012; CHANDRA et al., 2012; NAKHJAVANI et al., 2013;). Diarreias por aEPEC são geralmente mais persistentes do que as causadas por outros patógenos e esta bactéria parece permanecer no intestino por períodos mais longos do que outras DEC. Esta persistência pode estar relacionada à habilidade de formar microcolônias e a capacidade de produzir biofilme. Moreira e colaboradores (2006) demonstraram que tEPEC é capaz de formar biofilme tanto em superfícies abióticas como vidro e poliestireno, quanto em superfícies bióticas como células epiteliais pré-fixadas.

Até recentemente, micro-organismos eram tidos como organismos unicelulares independentes e solitários. Ao contrário disso, na maioria das vezes são encontrados acumulados em interfaces formando agregados polimicrobianos (DONLAN, COSTERTON, 2002). A sobrevivência de patógenos humanos por longos períodos em água, dejetos animais e em uma variedade de solos agrários foi relacionada à formação de biofilme, e esta estrutura foi identificada como o fator 
principal na incapacidade de remoção de patógenos em ações de higienização e sanitização em indústrias alimentícias (ANNOUS et al., 2005). As interações em comunidades bacterianas podem promover a disseminação de marcadores de resistência contra antimicrobianos, além da transferência de fatores de virulência (VUONG et al., 2004). Como resultado, patógenos formadores de biofilme são persistentes, estabelecendo infecções crônicas e recorrentes (FEY, 2010; KURAMITSU, WANG, 2011).

A transição do crescimento planctônico para o crescimento séssil em biofilmes ocorre como resposta a alterações ambientais, envolvendo múltiplas redes regulatórias que traduzem sinais para mudanças na expressão de genes. Esta reprogramação celular altera a expressão de moléculas de superfície, utilização de nutrientes e fatores de virulência, preparando a bactéria para a sua sobrevivência em ambientes desfavoráveis (PRATT, KOLTER, 1998; BELOIN et al., 2004). Vários fatores estão implicados no desenvolvimento de um biofilme, tais como: temperatura, presença de agentes antimicrobianos, densidade populacional, forças hidrodinâmicas, características do substrato, $\mathrm{pH}$, disponibilidade de nutrientes, gradiente de oxigênio, assim como as concentrações dos metabólitos microbianos (NAVES et al., 2008).

Biofilmes formados em superfícies apresentam uma estrutura característica composta de microcolônias envoltas por uma matriz exopolimérica (EPS) constituída de proteínas, ácidos nucléicos e polissacarídeos. Nesta complexa comunidade, as células agem como um sistema coletivo ao invés de células individuais, permeadas e interligadas por canais que fazem o transporte de água e nutrientes. O EPS do biofilme pode conferir a capacidade de adesão em superfícies abióticas como vidro, poliestireno, fibra de aço e até mesmo em superfícies bióticas como células e tecidos, podendo inclusive ser formados na interface ar-líquido, líquido-líquido ou até mesmo em flóculos suspensos (COSTERTON et al., 1995; DAVEY, O'TOOLE, 2000). Embora seja raro, biofilmes podem ser formados a partir de uma única espécie bacteriana, porém, é mais comum serem formados por mais de uma espécie microbiana (DAVEY, O'TOOLE, 2000). Deste modo, a formação de biofilmes é uma estratégia usada por uma gama de micro-organismos em um ambiente natural para a sua sobrevivência (COSTERTON et al., 1987).

A composição do EPS pode variar de acordo com as espécies microbianas. Já foi demonstrado que em $E$. coli a co-produção de fímbria curli e celulose tem 
papel importante na estabilização da matriz extracelular (ZOGAJ et al., 2001). Fímbrias curli são estruturas da matriz extracelular associadas aos estágios iniciais de adesão e virulência. Estas fímbrias consistem em filamentos protéicos adesivos que formam uma estrutura em espiral na superfície da célula. Esta estrutura apresenta afinidade por componentes da matriz extracelular eucariótica como laminina, fibronectinas e plasminogênio e desempenha papel importante nas interações interbacterianas e na adesão a superfícies abióticas (PRIGENTCOMBARET et al., 2001; ZOGAJ et al., 2003). Outro importante constituinte da matriz extracelular é a celulose. Este polissacarídeo tem um papel importante em infecções causadas por E. coli, Salmonella enterica subsp. enterica serovar Typhimurium (ZOGAJ et al., 2001; ROMLING, 2002; UDE et al., 2006; WANG et al., 2006).

Existem evidências em diversas espécies bacterianas de que a formação de biofilme é um processo cautelosamente orquestrado e controlado por Quorum Sensing (COLE et al., 2004; GONZÁLEZ-BARRIOS et al., 2006; REESER et al., 2007; LEE et al., 2007). O biofilme é um ambiente que estimula a produção de autoindutores, pois proporciona um local de alta densidade celular em que as células estão em contato próximo umas com as outras (SHROUT et al., 2011). Quorum Sensing e a formação de biofilme estão comumente relacionados, e é provável que esta interação seja central na patogênese de diversas infecções bacterianas (DAVIES et al., 1998).

A regulação de comportamentos coletivos bacterianos dependentes da densidade celular foi descrita por Nealson e colaboradores (1970), e denominada Quorum Sensing por Fuqua, Winans e Greenberg (1994). A noção de que bactérias se comunicam umas com as outras através de uma linguagem química deu início a um aumento no volume de estudos nesta área, resultando em novas descobertas da complexa comunicação molecular entre bactérias. O termo autoindução foi designado para descrever as mudanças fenotípicas expressas por bactérias em resposta a moléculas chamadas autoindutores, produzidas pelas próprias bactérias. Estas moléculas acumulam-se no meio extracelular até atingir um limite crítico de concentração para sua detecção, acarretando em sinalizações intracelulares e respostas efetoras (BASSLER, 1999; BASSLER, LOSICK, 2006).

Diversos estudos descreveram a existência de pelo menos 3 sistemas relacionados ao Quorum Sensing em bactérias Gram-negativas, LuxIR/Al-1, 
LuxS/AI-2 e QseBC/AI-3/Epinefrina/Norepinefrina (PARKER, SPERANDIO, 2009). Apesar dos gêneros Escherichia, Salmonella, Klebsiella, Shigella e Enterobacter não serem capazes de produzir AHLs, eles codificam uma proteína receptora homóloga a LuxR chamada inibidor da repressão da divisão celular (SdiA) (DYSZEL et al., 2010). Este receptor é capaz de responder a Al-1 produzido por outras espécies bacterianas, servindo como um sensor de sinalização interespecífica (SMITH, AHMER, 2003; AHMER, 2004).

O gene luxS é responsável por codificar a enzima LuxS, envolvida no ciclo do metil (AMC), uma via metabólica essencial para a reutilização de $S$ adenosilmetionina (SAM) e principal doadora de metil para a célula (WALTERS et al., 2006; CHEN et al., 2002). Um dos subprodutos desta via metabólica é o composto 4,5-dihidroxi-2,3-pentadiona (DPD), molécula precursora de Al-2 que, quando solubilizada pode tomar diferentes isoformas (WALTERS et al., 2006, CHEN et al., 2002). Homólogos de luxS já foram identificados em diversas espécies bacterianas, indicando que a produção de Al-2 é um mecanismo amplamente disseminado, inclusive entre espécies residentes do trato gastrointestinal (LUKÁS et al., 2008).

O sistema de dois componentes QseBC tem um papel importante na regulação do operon flagelar flhDC, expressão de fímbria curli, formação de biofilme e transcrição de LEE em E. coli (SPERANDIO et al., 2002, CLARKE et al., 2006; HUGHES et al., 2009). Os sinais reconhecidos pela proteína sensora QseC são Al3, um autoindutor produzido por bactérias de diferentes espécies, epinefrina e norepinefrina, hormônios produzidos pelo sistema nervoso de mamíferos (WALTERS, SPERANDIO, 2006).

Bactérias frequentemente usam mais de um Al para regular múltiplas características e, de fato, diversos circuitos de Quorum Sensing podem estar interligados direta ou indiretamente (MILLER et al., 2002). Por estes sistemas envolverem complexas cascatas de sinalização, é possível que na ausência de uma via regulada por um sistema de Quorum Sensing, outra via seja ativada de maneira compensatória.

A transmissão direta de aEPEC entre animais e humanos, embora escassamente relatada, pode envolver sorogrupos relacionados a infecções humanas. Amostras de aEPEC já foram isoladas de animais domésticos (cães e gatos), cavalos, veados e saguis (BEAUDRY et al., 1996; GOFFAUX et al., 2000; 
NAKAZATO et al., 2004; KRAUSE et al., 2005; ISHIl et al., 2007). Embora existam poucas evidências da transmissão direta entre animais e humanos (RODRIGUES et al., 2004), algumas amostras de aEPEC isoladas de animais pertencem a sorogrupos envolvidos em doenças humanas (AIDAR et al., 2000; CARVALHO et al., 2003; AKTAN et al., 2004; NAKAZATO et al., 2004; KRAUSE et al., 2005; LEOMIL et al., 2005), sugerindo que estes animais representam reservatórios deste patótipo, podendo potencialmente ser transmitido a humanos. Para conseguir percorrer essa via de transmissão, as bactérias devem ser capazes de se adaptar a diferentes condições ambientais, dentro e fora de seu hospedeiro. Fenótipos como motilidade, formação de biofilme e outros fatores de colonização e infecção devem ser rigidamente regulados e coordenados para que a bactéria não desperdice energia e consiga sobreviver nos diferentes nichos.

Desta forma, a análise da capacidade de adaptação a diferentes nichos por uma amostra de origem animal, assim como da regulação de diversos fatores em condições semelhantes às encontradas no ambiente e no hospedeiro é de grande valia. 


\section{REVISÃO BIBLIOGRÁFICA}

\subsection{Micro-organismos do Trato Gastrointestinal}

O trato gastrointestinal (TGI) é composto de diversos ambientes, incluindo a cavidade oral, o estômago, o intestino delgado e o intestino grosso (cólon). Dentro destes ambientes, existem diversos microambientes onde bactérias vivem, como no lúmen do intestino, a camada mucosa sob o epitélio, criptas mucosas e na superfície de células epiteliais (XU et al., 2003). Estima-se que em humanos, a população microbiana residente do TGI ( $10^{14}$ de células bacterianas) seja maior do que o total de células mamíferas por pelo menos uma ordem de magnitude, tornando o TGI o mais complexo ambiente do hospedeiro mamífero (BERG, 1996). Contando com aproximadamente 500 a 1000 espécies bacterianas, o intestino humano representa uma enorme diversidade genética (HOOPER, GORDON, 2001; ECKBURG et al., 2005).

Um fato intrigante sobre a população microbiana do TGl é que a maioria das espécies residentes ainda não foi cultivada in vitro (VENTER et al., 2004). Das bactérias comensais já cultivadas, aproximadamente $99,9 \%$ são anaeróbios estritos e os gêneros predominantes são Bacteroides, Bifidobacterium, Eubacterium, Lactobacillus, Clostridium, Fusobacterium, Peptococcus, Peptostreptococcus, Escherichia, e Veillonella (MACFARLANE, MACFARLANE, 1997). Variações da microbiota intestinal resultam de fatores genéticos e ambientais como dieta, condições de habitação e local de nascimento (ECKBURG et al., 2005).

Existe uma relação mútua benéfica entre o intestino humano e muitos de seus simbiontes: o intestino humano fornece nutrientes para bactérias residentes enquanto as bactérias contribuem na digestão de alimentos e na absorção de nutrientes, produção de vitaminas como biotina e vitamina $\mathrm{K}$, na modulação do sistema imune e dificultam a colonização de micro-organismos patogênicos (BACKHED et al., 2005). Bactérias residentes fornecem uma linha de defesa crucial contra a colonização de patógenos pela competição por nutrientes e sítios de adesão no epitélio colônico, um mecanismo conhecido como "efeito barreira" (GUARNER, MALAGELADA, 2003). Quando o ambiente em que uma bactéria está inserida sofre mudanças, esta responde através de alterações na expressão de genes, resultando em uma maior chance de sobrevivência. $O$ que consideramos 
como patogênese nada mais é do que uma adaptação do comportamento bacteriano para sua sobrevivência e permanência em um novo nicho (PARKER, SPERANDIO, 2009).

\subsection{Escherichia coli}

A bactéria Escherichia coli hoje em dia não é apenas assunto de acadêmicos e profissionais da área da saúde. Devido aos problemas de saneamento básico precário encontrados em diversas partes do Brasil e do mundo, principalmente em países em desenvolvimento, a população está ciente das mazelas causadas por este organismo. Inicialmente descrita como uma bactéria comensal habitante do TGI de crianças saudáveis, ao longo dos anos este residente aparentemente inofensivo foi sendo revelado como um agente patológico responsável por diversas doenças infecciosas.

$\mathrm{Na}$ época de sua descrição, o conhecimento e recursos ainda eram escassos para associar determinadas doenças ao organismo em questão. Este problema se intensificou pela detecção de patótipos semelhantes em diferentes sítios anatômicos do corpo como no trato urinário e outras regiões extra-intestinais (HYMAN, MANN, 1929). Em 1944, Kauffman propôs uma metodologia para a classificação sorológica

de $E$. coli baseada na identificação do antígeno $O$ (um componente do lipopolissacarídeo encontrado na membrana exterior de bactérias Gram-), antígeno H (proteína do flagelo), e antígeno K (cápsula composta de ácido polissacarídeo). Este modo de classificação permitiu a descoberta e diferenciação de diversas cepas de E. coli (KAUFFMAN, 1947 apud FRATAMICO et al., 2016).

Em virtude desta identificação elaborada por Kauffman, em 1945 o pediatra britânico John Bray foi capaz de associar uma linhagem particular de $E$. coli com a diarreia em crianças, sendo intitulada como Bacterium coli neapolitanum (BRAY, 1945). Nos períodos subsequentes diversas epidemias de diarreia associadas à $E$. coli foram relatadas, e para cada caso descrito, um nome diferente era dado à bactéria encontrada. Posteriormente, Bray constatou que todas as descrições referiam-se ao mesmo organismo (BRAY, 1949). Com a uniformização da nomenclatura de E. coli, as linhagens associadas a diarreias entre as décadas de 20 e 40 revelaram-se pertencer a um pequeno grupo de sorogrupos $O$, particularmente O55 e O111 (NETER, 1951; RAPPAPORT, HENNIG, 1952; HINTON, 
MACGREGOR, 1958).

Com o avanço da tecnologia e recursos disponíveis, a tipagem de microorganismos foi modernizada e metodologias mais sofisticadas foram criadas. A tipagem molecular, ao contrário da tipagem tradicional baseada no uso de anticorpos, se refere a ensaios com enfoque na análise de diferenças genômicas utilizando técnicas como Pulsed field gel electrophoresis (PFGE), multilocus sequencing typing (MLST), whole genome sequencing (WGS) e, recentemente, até mesmo a popular metodologia Clustered Regularly Interspaced Short Palindromic Repeats (CRISPR) (FRATAMICO et al., 2016). Esta abordagem mais sensível e específica permitiu o reconhecimento de determinados organismos responsáveis por diversos surtos de doenças. Atualmente, são reconhecidos 188 sorogrupos $O$ e 53 sorogrupos H de E. coli (ORSKOV, ORSKOV, 1984; EWING, 1986; SCHEUTZ et al., 2004). As linhagens de E. coli capazes de provocar diarreia foram divididas em um grupo particular chamado de E. coli diarreiogênicas (DEC).

\subsection{Escherichia coli diarreiogênicas}

A interação entre linhagens de E. coli comensais do TGI com organismos patogênicos favoreceu a aquisição de elementos genéticos móveis (plasmídeos, ilhas de patogenicidade, transposons, bacteriófagos). Estes elementos móveis podem ser responsáveis pela codificação de fatores de virulência, provocando uma grande variedade de doenças em indivíduos saudáveis como, diarreia aguda, disenteria, sepse e meningite, síndrome hemolítica urêmica, e infecções do trato urinário (KAPER et al., 2004).

As DEC compreendem diferentes patótipos, designados como: E. coli enteropatogênica (EPEC), E. coli enterohemorrágica (EHEC), E. coli Enteroagregativa (EAEC), E. coli enterotoxigênica (ETEC), E. coli enteroinvasora (EIEC) e E. coli que adere de forma difusa às células epiteliais (DAEC) (NATARO, KAPER, 1998). Os patótipos de DEC diferem entre si de acordo com as características das infecções intestinais que são capazes de causar. Apresentam mecanismos de virulência específicos, causam manifestações clínicas distintas, apresentam aspectos epidemiológicos diferentes, pertencem a sorotipos $\mathrm{O}: \mathrm{H}$ definidos, além de apresentarem tipos específicos de interação com células epiteliais in vitro (NATARO, KAPER, 1998). 


\subsubsection{EPEC}

O termo EPEC foi utilizado pela primeira vez em 1955 para descrever amostras de $E$. coli epidemiologicamente relacionadas a uma série de surtos de diarreia em crianças nas décadas de 40 e 50 (BRAY, 1945; ROBINS-BROWNE, 1987). EPEC hoje em dia são definidas por ter a capacidade de causar diarreia, produzir a lesão histopatológica no intestino epitelial denominada attaching and effacing (A/E) e pela ausência da produção de toxina de Shiga (NATARO, KAPER, 1998).

As EPEC continuam sendo uma das principais causas de diarreia em países em desenvolvimento, particularmente em crianças com idade inferior a um ano, ceifando a vida de milhões de crianças na Ásia, África e nas Américas anualmente (ALBERT et al., 1995; ALBERT, 1996; TORRES et al., 2001). As EPEC correspondem aos seguintes sorogrupos clássicos de E. coli: O26, 055, O86, 0111 , O114, O119, O125, O126, O127, O128, O142, O158 (WHO, 1987). Em 1995 foi realizado o segundo simpósio internacional de EPEC, e nesta conferência EPEC foram classificadas em típicas e atípicas (KAPER, 1996). EPEC típicas (tEPEC) são definidas por albergar um plasmídeo de virulência chamado EPEC adherence factor (EAF), responsável por conferir o padrão de adesão localizada (LA) em culturas de células epiteliais, mediado pela ação de uma fímbria de tipo IV chamada bundleforming pilus (BFP). EAF contém também o operon perABC (plasmid encoded regulator), envolvido na regulação de BFP e de genes envolvidos na formação da lesão A/E. Amostras de EPEC que não contém o plasmídeo EAF foram classificadas como EPEC atípicas (aEPEC) (NATARO, KAPER, 1998).

\subsubsection{EPEC atípica}

A existência de amostras de aEPEC contendo o plasmídeo EAF já foi relatada, porém, geralmente apresentam uma cópia não funcional do operon bfp, dificultando a diferenciação entre tEPEC e aEPEC baseando-se na detecção do gene bfpA (BORTOLINI et al. 1999; TRABULSI et al. 2002 ; ABE et al. 2009; TEIXEIRA et al. 2015). Uma maneira mais confiável de se confirmar a identificação de EPEC é a observação do padrão de adesão apresentado quando em contato com células epiteliais. Enquanto tEPEC produzem microcolônias compactas e o 
padrão LA a partir de 3 horas de infecção in vitro, aEPEC são incapazes de apresentar este fenótipo pela falta de BFP, apresentando o padrão de adesão chamado localizado-like (LAL) após longos períodos de interação com células epiteliais (6 horas ou mais) (TRABULSI, 2002). Este padrão de adesão é caracterizado por produzir microcolônias mais frouxas em comparação ao padrão LA (TRABULSI, 2002). Além de LAL, algumas cepas de aEPEC são capazes de aderir em células HeLa/HEp-2 apresentando os padrões de adesão agregativo (AA), difuso (DA) ou até mesmo sem um padrão de adesão definido (VIEIRA et al. 2001; ABE et al. 2009 ; SCALETSKY et al. 2009 ; GOMES et al. 2011).

\subsection{Lesão Attaching and Effacing}

Primeiramente descrita por Moon e colaboradores em 1983, a lesão A/E é caracterizada pela adesão íntima da bactéria à célula epitelial, promovendo a destruição das microvilosidades, o rearranjo do citoesqueleto e polimerização de actina celular (F-actina), formando estruturas semelhantes a pedestais (KAPER et al., 2004). Essa lesão pode ser observada em mucosa intestinal de animais e seres humanos infectados natural ou experimentalmente, assim como em células epiteliais cultivadas (ROTHBAUM et al., 1982; KNUTTON et al., 1987; FINLAY et al., 1992). Os fatores de virulência necessários para a formação da lesão $A / E$ estão contidos em uma ilha de patogenicidade chamada Locus of Enterocyte Effacement (LEE) (KAPER et al., 2004). Linhagens comensais de E. coli, ETEC, EAEC ou DAEC não apresentam a região LEE em seus genomas, mas LEE é encontrada em vários outros patógenos capazes de formar a lesão $A / E$, dentre os quais, EHEC, Citrobacter rodentium, amostras diarreiogênicas de Hafnia alvei e diversas amostras de E. coli associadas a diarreia e outras infecções entéricas em coelhos, porcos, bezerros e cachorros (NATARO, KAPER, 1998).

A região LEE é organizada em cinco operons principais (LEE1 a LEE5) e outras unidades transcricionais menores (YERUSHALMI et al., 2014). LEE1, LEE2, LEE3 e LEE7 expressam componentes de um sistema de secreção tipo III (TTSS) e reguladores da região LEE (LEE encoded regulator - Ler, Global Regulator of LEEActivator - GrlA, Global Regulator of LEE-Repressor - GrIR) (ELLIOTT et al., 2000). LEE4 codifica proteínas translocadas por este sistema de secreção (EspA, EspB, EspD - EPEC secreted protein). LEE5 alberga genes que codificam a adesina 
intimina (eae) e o seu receptor Tir (translocated intimin receptor) (ELLIOTT et al., 1998; MELLIES et al., 1999; SÁNCHEZ-SANMARTÍN et al., 2001).

A regulação de LEE é multifatorial e envolve diversas proteínas. A proteína Ler regula de forma positiva genes da região LEE e genes localizados externamente a LEE, que exercem funções na formação da lesão $A / E$ tais como, non-LEEencoded effector $A$ (nleA), long polar fimbriae (Ipf), e espC (KAPER et al., 2004; TORRES et al., 2007; ROE et al., 2007). GrlA e GrlR são proteínas que regulam a expressão de LEE de forma positiva e negativa, respectivamente (DENG et al., 2004).

Além desses fatores, em tEPEC a regulação de LEE envolve o operon perABC. A proteína PerA é responsável pela ativação da expressão do operon bfp, PerC induz a expressão de ler, que por sua vez ativa a expressão de genes da região LEE (WONG et al. 2011; CROXEN et al. 2013). Desta forma, PerC ou GrlA podem ativar a expressão de LEE de forma independente (BUSTAMANTE et al. 2011). Recentemente, um estudo realizado por Bueris e colaboradores (2015) demonstrou que a ausência de proteínas Per na cascata de regulação de fatores de virulência está relacionada ao retardo na progressão da lesão $A / E$ observado em amostras de aEPEC.

\subsection{Epidemiologia e relação com diarreias infecciosas}

"Introduzo na poesia a palavra diarreia; Que mata mais do que faca, mais que bala de fuzil, homem, mulher e criança; a diarreia, no Rio Grande do Norte, de cem crianças que nascem, setenta e seis leva à morte; é como uma bomba D; é uma bomba que elimina vários milhões de crianças; sobretudo no Nordeste." No poema "A Bomba Suja", escrito em 1962 pelo poeta Ferreira Gullar, é relatado o quadro social da população de baixa renda, que mesmo nos dias de hoje é deixada à margem da sociedade. Apesar de ser um texto poético, serve como documento para evidenciar o problema histórico de complicações causadas pela diarreia.

A diarreia continua sendo a segunda maior causa de morte de crianças no mundo. Aproximadamente uma em cada cinco mortes - cerca de 1,5 milhões por ano - é devido à diarreia, sendo mais letal do que a AIDS, malária e sarampo. Apenas $39 \%$ de crianças com diarreia em países em desenvolvimento recebem tratamento apropriado (WHO, 2009). 
Diarreia é um sintoma comum de infecções gastrointestinais causadas por uma grande variedade de patógenos, incluindo bactérias, vírus e protozoários. A maioria dos patógenos capazes de causar diarreia compartilha um modo de transmissão via fecal-oral, quando o patógeno se transfere do material fecal para o alimento ou água, que então são ingeridos (LEVINE, EDELMAN, 1984). Dentre os patógenos bacterianos responsáveis por estas infecções estão E. coli, Shigella, Campylobacter, Salmonella e V. cholerae (WHO, 2009).

A região geográfica e a classe econômica são fatores que contribuem para a epidemiologia de casos de diarreia associados à EPEC (MARANHÃO et al., 2008). Por muitas décadas, sorotipos de tEPEC foram relacionados a casos de diarreia em crianças com menos de um ano de idade em centros urbanos carentes (NATARO, KAPER, 1998). Estudos realizados no Brasil, Chile, México e África do Sul demonstraram que $30-40 \%$ de casos de diarreia em crianças foram causados por sorotipos de tEPEC (OCHOA et al., 2008). Porém, a epidemiologia de EPEC tem mudado com o avanço dos anos, e a incidência de infecções por aEPEC tem aumentado gradativamente, se sobrepondo a casos de diarreia associados a tEPEC em países desenvolvidos e em desenvolvimento (OCHOA et al., 2008; HU, TORRES, 2015).

Um estudo realizado nos Estados Unidos da América (EUA) identificou aEPEC em crianças com diarreia na mesma proporção que as encontradas em países da América Latina (FOSTER et al., 2015). Embora tenha sido relatada a presença de aEPEC em casos de diarreia aguda, alguns estudos tem associado este patótipo como a causa de diarreia persistente e diarreia sanguinolenta $(\mathrm{HU}$, TORRES, 2015). Já foram descritos casos de pacientes de idades variadas e adultos portadores de HIV infectados por aEPEC, enquanto tEPEC afeta predominantemente crianças (GOMES et al., 2004; NUNES et al., 2012; LOZER, SOUZA, 2013; ASSIS et al., 2014; DIAS et al., 2016).

Em diferentes centros urbanos do Brasil, amostras de aEPEC foram identificadas como as mais predominantes em casos de diarreia (FRANZOLIN et al., 2005; ARAUJO et al., 2007; SPANO et al., 2008; MORENO et al., 2010). Em um estudo realizado por Lozer e colaboradores (2013) com crianças de comunidades rurais de baixo nível socioeconômico no sudeste do Brasil, a detecção de aEPEC foi mais frequente do que tEPEC, corroborando com dados atuais que sugerem sua maior prevalência tanto em países desenvolvidos quanto em países em 
desenvolvimento (NATARO, KAPER, 1998; BUERIS et al., 2007; OCHOA et al., 2009). Estes dados destacam a emergência de aEPEC no Brasil.

Enquanto tEPEC são raramente encontrados em animais, tendo humanos como seu principal reservatório, diversas amostras de aEPEC foram isoladas de animais sadios e com diarreia, assim como no ambiente (AIDAR et al., 2000; TRABULSI et al., 2002; AKTAN et al., 2004; KRAUSE et al., 2005; LEOMIL et al., 2005). Sorogrupos envolvidos em diarreias em humanos já foram isolados de animais (O26, 0103, 0119, 0128, O142, O157), embora não tenha sido confirmada a transmissão direta entre animais e humanos (AIDAR et al., 2000; CARVALHO et al., 2003; AKTAN et al., 2004; NAKAZATO et al., 2004; KRAUSE et al., 2005; LEOMIL et al., 2005; KOLENDA et al., 2015). No Brasil, em um estudo realizado por de Almeida e colaboradores (2012), 50,8\% de cães com diarreia e 41,7\% de cães assintomáticos apresentaram infecção por aEPEC. Através de tipagem molecular, tem sido demonstrado que animais domésticos e selvagens podem ser fontes em potencial de possíveis infecções em humanos por aEPEC em diversas regiões, incluindo países da América Latina, EUA e Canadá (NAKAZATO et al. 2004; KRAUSE et al. 2005; MORATO et al. 2009; BENTANCOR et al. 2010; de ALMEIDA et al. 2012; OTERO et al., 2013). Rodrigues e colaboradores (2004) foram capazes de isolar amostras semelhantes de tEPEC provenientes das fezes de uma criança de 3 anos de idade saudável e de seu cão de estimação com diarreia. Análises genotípicas e fenotípicas demonstraram que as cepas isoladas de ambos os indivíduos pertenciam ao mesmo sorogrupo $\mathrm{O}: \mathrm{H}\left(\mathrm{O} 111: \mathrm{H}^{-}\right)$e possivelmente ao mesmo clone de E. coli, normalmente associado a humanos.

A transmissão de EPEC entre um hospedeiro humano e um hospedeiro animal necessita que a bactéria seja capaz de se adaptar às diferentes condições que encontra quando alterna de um nicho para o outro. A sobrevivência fora do hospedeiro é crucial neste processo, e a formação de biofilme representa uma estratégia de sobrevivência em ambientes adversos e desfavoráveis.

\subsection{Biofilme}

Até recentemente, micro-organismos eram considerados organismos unicelulares independentes e solitários. Ao contrário disso, são definidos como organismos unicelulares que na maioria das vezes são encontrados acumulados em 
interfaces, formando agregados polimicrobianos na forma de flóculos ou biofilmes (DONLAN, COSTERTON, 2002).

Existem evidências de microcolônias de biofilme em formações geológicas de aproximadamente 3 bilhões de anos de idade (RASMUSSEN, 2000; WESTALL et al., 2001). Estruturas similares podem ser encontradas em ambientes hidrotermais modernos como fontes termais e fendas no oceano (REYSENBACH, CADY, 2001; TAYLOR et al., 1999). Estes dados sugerem que a formação de biofilme é um processo remoto e característico de procariotos.

Biofilmes podem ser formados por uma única espécie, mas na maioria dos casos naturais vivem como comunidades microbianas heterogêneas (JURETSCHKO et al., 2002; TAYLOR et al, 2004; LYAUTEY et al., 2005) nas quais uma única espécie ou um número restrito de espécies é numericamente e funcionalmente dominante (TUJULA et al., 2006).

A formação do biofilme ocorre em quatro etapas principais, que requerem a transcrição e expressão coordenada de diversas estruturas e fenótipos microbianos, como motilidade, flagelo e adesinas (WOOD et al., 2006).

\subsubsection{Adesão inicial - "Nadar ou ficar"}

A adesão bacteriana inicial é dinâmica e reversível, se perturbada por forças hidrodinâmicas, por forças repulsivas, ou em resposta à disponibilidade de nutrientes, a célula bacteriana é capaz de se desprender da superfície e se juntar à população planctônica novamente (DUNNE, 2002; BANIN et al., 2005; ANDERSON et al., 2008; WU, OUTTEN, 2009). Apesar do vasto conhecimento dos eventos que ocorrem após o reconhecimento da superfície de contato, pouco é sabido dos mecanismos utilizados para sentir superfícies e quais os sinais que influenciam o comportamento de continuar se locomovendo ou aderir, mudando de um estilo de vida móvel para um estilo de vida séssil (BELAS, 2014). Diversos fatores estão envolvidos para que a adesão de bactérias à superfície seja bem-sucedida, como por exemplo, a presença de apêndices celulares como flagelo, pili e fímbrias (LEJEUNE, 2003).

O flagelo tem um papel crítico na percepção da superfície e nos estágios iniciais da adesão que levam à formação do biofilme (GODE-POTRATZ et al., 2011; BELAS, 2013). A importância deste apêndice na adesão inicial já foi observada em 
diversos patógenos, incluindo $P$. aeruginosa, $V$. cholerae, Listeria monocytogenes e E. coli (O' TOOLE, KOLTER, 1998; PRATT, KOLTER, 1998; WATNICK, KOLTER, 1999; KLAUSEN et al., 2003; LEMON et al., 2007). A ação do flagelo permite que a bactéria se mova e supere forças eletrostáticas que podem existir entre a superfície celular e a superfície do substrato de aderência, como um material abiótico ou o hospedeiro (O' TOOLE, KOLTER, 1998).

O operon flhDC (flagellar class II regulon transcriptional activator) e outros reguladores da expressão do flagelo são fundamentais para o mecanismo de "nadarou-ficar", assim como os reguladores RpoS (RNA polimerase sigma S), CsgD (curli specific gene D), e CpxR (PETROVA, SAUER, 2012). RpoS tem um papel importante na formação do biofilme pois codifica o fator sigma da fase estacionária $\left(\sigma_{s}\right)$, que regula uma variedade de genes relacionados a estresse, incluindo CpxR e CsgD, que exercem regulação negativa em genes flagelares (DUDIN et al., 2014). Outro gene regulado por RpoS é o gene $y c g R$ (flagellar velocity braking) de E. coli, que codifica a proteína que age como uma chave inglesa, interagindo com o rotor da proteína FliG (flagellar motor switch protein G), impedindo sua rotação (BOEHM, et al., 2010). YcgR também é controlado ou influenciado pelo mensageiro secundário c-di-GMP (diguanilato monofosfato cíclico) (POVOLOTSKY, HENGGE, 2012). Alta concentração intracelular de c-di-GMP favorece adesão à superfície e formação de biofilme, enquanto baixos níveis deste mensageiro são correlacionados com comportamentos de motilidade e planctônicos (WOLFE, VISICK, 2008).

Sentir superfícies pelo flagelo não é o único meio de detectar e responder ao contato com superfícies. Nem toda via envolvida neste sistema envolve a ação deste apêndice, pois bactérias imóveis formam biofilmes sem a necessidade de flagelo (BELAS, 2014). O controle do mecanismo de "nadar-ou-ficar" que leva à formação de biofilme parece envolver também a inibição da síntese do flagelo, unido ao aumento da síntese de polímeros e estruturas necessárias para adesão duradoura à superfície (GUTTENPLAN, KEARNS, 2013).

E. coli codifica pili pela transcrição do operon fim (fimbriae), e a adesão está relacionada à produção de pili tipo I, tipo IV e P (HULL et al., 1981). No ápice da estrutura de pili tipo I (ou fímbria tipo I) de E. coli existe um receptor específico de manose chamado FimH (BAORTO et al., 1997). Receptores de manose contribuem na adesão ao epitélio do hospedeiro (CONNELL et al., 1996). Fímbrias curli são organelas associadas aos estágios iniciais de adesão e virulência em $E$. coli. 
Consistem em filamentos proteicos adesivos que formam uma estrutura em espiral na superfície da célula. Apresentam afinidade por componentes da matriz extracelular de células eucarióticas como laminina, fibronectina, e plasminogênio e exercem papel na adesão célula-célula (ÓLSEN et al., 1993; VIDAL et al., 1998; COOKSON et al., 2002; UHLICH et al., 2006).

A expressão de curli requer a transcrição de dois operons distintos, o operon $\operatorname{csg} B A C$, que codifica os componentes principais da fímbria, e o operon csgDEFG. A proteína CsgD, derivada da família LuxR de reguladores transcricionais, é o regulador global desta estrutura e controla a transcrição de múltiplos genes, incluindo o operon csgBAC (ARNQVIST et al., 1994; GERSTEL, ROMLING, 2003). CsgD também controla a produção de celulose através da transcrição do gene adrA (diguanylate cyclase), que está relacionado à formação de matriz extracelular do biofilme (RÖMLING et al., 2000). O operon csgDEFG codifica tanto CsgD como um sistema de transporte específico para curli mediado pelas proteínas CsgEFG. As subunidades proteicas de curli são produzidas na presença de estresse celular e ambiental, como baixa temperatura (<32 ㄷ) , escassez de nutrientes e baixa osmolaridade (ÓLSEN et al., 1993; RÖMLING et al., 1998; GERSTEL et al., 2001). A formação reduzida de biofilme está relacionada à menor produção de CsgA, subunidade proteica principal de curli (DOREL et al., 1999).

A regulação negativa de curli ocorre pela ligação de $\operatorname{CpxR}$ fosforilado ao promotor de $\operatorname{csg} D$, reprimindo-o. Em biofilmes maduros a maioria do sistema CpxA/CpxR estão em atividade (BELOIN et al., 2004). Os eventos da adesão inicial já ocorreram, portanto muitos dos apêndices requeridos para adesão não são mais necessários. O papel positivo deste sistema está associado a células dormentes ou persistentes em E. coli. É improvável que este sistema esteja envolvido na dispersão de células em biofilmes, pois genes relacionados à motilidade como flgM (flagelo) também são negativamente regulados por este sistema (DE WULF et al., 2002). O sistema EnvZ/OmpR (osmolarity-responsive two component signal transduction system histidine kinase) faz a regulação positiva da produção de fímbria curli pela ligação da proteína $\mathrm{OmpR}$ à região promotora de $\operatorname{csg} D$, agindo como um antagonista de CpxR. EnvZ é uma histidina quinase que regula a afinidade da ligação de OmpR ao seu alvo, sendo fosforilada na presença de estímulos como alta osmolaridade (RAMPERSAUD et al., 1994). 


\subsubsection{Produção de EPS - adesão irreversível}

Se a bactéria é capaz de superar condições adversas e se manter firmemente aderida à superfície, é iniciada a produção de matriz extracelular polimérica (EPS), fazendo desta uma adesão irreversível. De modo geral, a EPS é constituída de proteínas, ácidos nucleicos e polissacarídeos (ANNOUS et al., 2009). Esta estrutura imobiliza as células do biofilme e as mantém em contato próximo, permitindo uma intensa comunicação célula-célula e a formação de interações sinergéticas. Devido à retenção de enzimas extracelulares, um sistema digestivo externo versátil é gerado, captando e dissolvendo nutrientes da fase aquosa e permitindo que sejam utilizados como fonte de energia. A matriz também funciona como um depósito de reciclagem mantendo todos os componentes liberados da lise celular disponíveis para uso (FLEMMING, WINGENDER, 2010).

A estabilidade da matriz do biofilme é devida ao emaranhamento entre EPS e interações físico-químicas entre as moléculas. Estas interações correspondem a diversas forças de ligação como forças atrativas eletrostáticas, forças repulsivas, pontes de hidrogênio, interações de van der Waals e forças iônicas atrativas (FLEMMING, WINGENDER, 2010). A água é o componente mais abundante da matriz, e a EPS pode agir como uma peneira molecular, sequestrando cátions, ânions, compostos apolares e outras partículas da fase aquosa (FLEMMING, LEIS, 2002). A morfologia do biofilme pode ser lisa e plana, rugosa, macia ou filamentosa, e também pode variar no seu grau de porosidade, podendo conter macrocolônias em forma de cogumelos cercadas de canais aquosos. Assim, são formados microhabitats bastante diversos em uma pequena escala, favorecendo a biodiversidade (FLEMMING, WINGENDER, 2010). A arquitetura dos biofilmes é influenciada por diversos fatores, incluindo a condição hidrodinâmica, concentração de nutrientes, comunicação celular, assim como exopolissacarídeos e proteínas, como demonstrado pela morfologia alterada em biofilmes produzidos por mutantes que carecem de componentes do EPS (FLEMMING, WINGENDER, 2010).

\subsubsection{Maturação do biofilme}

A formação do biofilme maduro é caracterizada pela formação de estruturas tridimensionais e camadas de EPS espessas. Em E. coli, o acúmulo e, ultimamente, 
a maturação do biofilme, correspondem ao aumento da produção de ácido colânico (CHEN et al., 2004). Este composto é importante na constituição da arquitetura do biofilme, mas não é essencial para que a formação de biofilme ocorra. O biofilme maduro exibe estruturas tridimensionais permeadas por canais aquosos, micro e macrocolônias heterogêneas e uma densa matriz de biofilme. Genes envolvidos na motilidade bacteriana são reprimidos, especialmente aqueles relacionados ao flagelo, e genes que promovem a produção de substâncias poliméricas extracelulares durante o estágio de maturação são transcritos ativamente (ZHAO et al., 2007). O processo de maturação do biofilme em E. coli ocorre pela repressão de genes envolvidos com a motilidade mediada por flagelo ( fli e flg) e pela transcrição de genes que correspondem à produção de ácido colânico (wca) e porina (ompC) (PRIGENT-COMBARET et al., 1999).

A celulose foi identificada primariamente como um componente importante na formação de películas de biofilme em E.coli comensal, e mais tarde foi demonstrada a sua coexpressão com curli em UPEC e E.coli isoladas do TGI (ZOGAJ et al., 2001, 2003; ROMLING, 2002; BOKRANZ et al., 2005; KAI-LARSEN et al., 2010). Celulose é o polímero de açúcar mais abundante do planeta e é encontrado no ciclo de vida da maioria dos seres vivos (ZOGAJ et al., 2001). É constituída de moléculas de glicose lineares interligadas por ligações $\beta-1-4$ e suas fibras são formadas por pontes de hidrogênio entre as cadeias de glicose. As camadas formadas são altamente estáveis e seu número pode variar dependendo da natureza do ambiente. Este polissacarídeo tem um papel importante em infecções relacionadas a biofilme causadas por E. coli, Klebsiella pneumoniae, Enterobacter spp., Citrobacter spp. e Salmonella enterica subsp. enterica serovar Typhimurium (ZOGAJ et al., 2001; ROMLING, 2002; UDE et al., 2006; WANG et al., 2006). Os genes envolvidos na produção de celulose em E. coli e S. typhimurium são chamados de bcs (bacterial cellulose synthesis). O operon de bcs é parcialmente regulado por AdfD, uma fímbria agregativa que aumenta a produção de celulose e curli (ZOGAJ et al., 2001). Em S. Typhimurium e E. coli a coprodução de fímbria agregativa e celulose resulta na formação de uma matriz extracelular rígida, em que a produção individual de fímbria ou celulose resulta em uma rede polimérica frágil (ZOGAJ et al., 2001), ressaltando o papel funcional da fímbria na estabilização da matriz. 


\subsubsection{Dispersão}

A dispersão ativa de células bacterianas em biofilmes é tipicamente precedida de lise celular localizada no centro do biofilme maduro (DESJARDIM et al., 1999; XU et al., 2000). As células mortas servem como nutrientes para bactérias que se tornarão células planctônicas. O desprendimento do biofilme ocorre tanto passivamente, devido a forças hidrodinâmicas (STOODLEY et al., 2001), ou em processos ativos em resposta à densidade populacional (SAUER et al., 2002), ou ainda, devido a mudanças na concentração de substrato e exposição a antimicrobianos (DALY et al., 1998). A secreção de enzimas para a dissolução de EPS também é um passo importante no processo de dispersão (BOYD et al.1994; LEE et al., 1996). Durante esta fase, genes importantes para um estilo de vida móvel, incluindo flagelo e proteínas envolvidas em quimiotaxia, são expressos ativamente. A repressão de genes relacionados com a formação de biofilme, como produção de EPS e fímbrias também é comum em células dispersivas (BARRAUD et al., 2006; ROLLET et al., 2008).

\subsection{A vida em comunidade dentro do biofilme}

O estilo de vida comunitário tem profundas consequências na vida microbiana e pode contribuir para sua sobrevivência e a rápida adaptação às alterações do ambiente. A vida em comunidades polimicrobianas confere vantagens como resistência a estresses químicos (pH e oxigênio) e estresses físicos (pressão, variações de temperatura) (DAVEY, O'TOOLE 2000; DONLAN, 2002). Diversos estudos já relataram que bactérias que vivem dentro de um biofilme são mais resistentes à ação de antibióticos (STEWART, COSTERTON, 2001; MAH, O'TOOLE, 2001; GILBERT et al., 2002). Esta característica é atribuída à penetração restrita de antimicrobianos e pela inatividade metabólica de bactérias desnutridas nas camadas mais profundas do biofilme, devido à dificuldade da difusão de nutrientes até este microambiente (COSTERTON et al., 1999; XU et al., 2000). Praticamente todo antimicrobiano é mais eficaz contra bactérias em fase de crescimento do que contra células em fase estacionária (ENG et al., 1991). Em condições in vitro, a concentração bactericida mínima (MBC) contra organismos aderidos pode ser de 3 a 4 ordens de magnitude mais alta do que para bactérias 
planctônicas (CERI et al., 1999).

Com o aumento da resistência de microorganismos a antibióticos, um relatório feito pela OMS em 2014 alertou sobre a possibilidade de um futuro em que infecções brandas e ferimentos leves seriam letais (WHO, 2014). Além disso, a formação de biofilme é capaz de tornar patógenos persistentes, estabelecendo infecções crônicas e recorrentes, como infecções das vias respiratórias ( $P$. aeruginosa) (KOCH, HOIBY, 1993; GOVAN, DERETIC, 1996), infecções urinárias (UPEC, Klebsiella pneumoniae) (FOXMAN, 2010), periodontite (biofilmes mistos de Streptococcus e outras bactérias) (KURAMITSU, WANG, 2011), infecções em instrumentos médicos (E. coli, Enterococcus faecalis e outros) (VENDITTI et al., 1993; FERRIERES et al., 2007; JACOBSEN et al., 2008; FEY, 2010).

A proximidade das células no biofilme facilita a troca de material genético com maior eficiência, promovendo a obtenção de fatores de virulência baseados em elementos genéticos móveis como plasmídeos, ilhas de patogenicidade e bacteriófagos (LEBARON et al., 1997; DAHLBERG et al., 1998; LICHT et al., 1999). Além disso, a aglomeração das células microbianas favorece a comunicação extracelular. A sinalização celular por Quorum Sensing está diretamente envolvida na regulação da formação e diferenciação do biofilme, principalmente por se tratar de um ambiente de alta densidade celular, onde as interações bactéria-bactéria ocorrem de forma intensa (KJELLEBERG, MOLIN, 2002).

\subsection{Comunicação célula-célula}

O maior entendimento da vida microbiana convivendo em comunidade na forma de biofilmes trouxe a ideia de que seres unicelulares como bactérias são capazes de se comportar como seres multicelulares. É ainda possível imaginar o próprio corpo humano como um consórcio celular composto de diversas espécies de seres vivos. Desde o surgimento da primeira célula até a evolução de organismos pluricelulares, a interação entre seres mais organizados com seres menos organizados estabeleceu um equilíbrio na natureza em que é impossível separar a existência entre um e outro. É difícil imaginar possíveis interações entre diferentes organismos sem a intermediação de um sistema de comunicação. Historicamente, a cultura humana evoluiu a passos largos graças à habilidade da comunicação na forma de gestos, desenhos, escrita e fala. Através da comunicação, é possível 
coordenar o comportamento coletivo e estabelecer comunidades que busquem um bem comum para a sua população.

A comunicação ocorre quando uma ação individual fornece um sinal para a mudança do comportamento de outro indivíduo. A evolução da comunicação depende do resultado desta sinalização em relação ao fitness de quem emite o sinal e de quem o recebe. A mudança no fitness de um organismo exerce uma pressão seletiva em genes que influenciam uma ação individual dentro de uma população. A seleção de genes na população depende da sobrevivência e reprodução dos indivíduos que os carregam (WILEY, 1983). A comunicação é um fenômeno social que humanos compartilham com outras espécies, porém, de maneiras diferentes. Existem evidências de comunicações entre animais, incluindo sinais de aviso, afeto, hábitos de caça e rituais de acasalamento (JIMÉNEZ AMADOR, CASAN CLARÀ, 2012). Plantas também são capazes de se comunicar através da emissão de substâncias químicas por folhas, flores e frutos (HEIL, 2011).

Com o surgimento das primeiras células há aproximadamente 3,8 bilhões de anos, desafios para a sobrevivência em um ambiente inóspito como a Terra favoreceram o desenvolvimento de células primitivas capazes de perceber as variações do meio externo e promover ajustes internos, adaptando-se às novas condições ambientais. Para que estas funções fossem realizadas de forma eficiente surgiram moléculas de sinalização entre as células e, nas membranas celulares, apareceram moléculas capazes de perceber sinais químicos e transmitir estas informações para dentro das células. O agrupamento de células em um novo organismo exigia que essas se comunicassem entre si, formando um ajuste homeostático de forma integrada e sincronizada. A sinalização inter e intracelular permitiu que as diferentes células de um mesmo organismo se comuniquem, integrando funções e coordenando eventos (AIRES, 2012).

Uma das maiores descobertas provenientes de estudos de genômica comparativa foi a inesperada grande diversidade dos sistemas de sinalização microbianos. O alinhamento e comparação de sequências de diferentes bactérias demonstrou a presença de regiões de resíduos de aminoácidos altamente conservadas, chamadas de motivos. A presença de dois ou mais motivos em uma porção proteica é denominada de domínio proteico, normalmente formados de 100200 resíduos de aminoácidos, mas este número é variável, podendo conter de 25 a 500 resíduos (GALPERIN, GOMELSKY, 2005). A transdução de sinais bacterianos 
compreende diversos domínios proteicos distintos e sua organização gera um sistema de regulação extremamente versátil, unindo um número limitado de domínios em uma enorme variedade de combinações possíveis (GALPERIN, GOMELSKY, 2005).

Há aproximadamente 30 anos foi descoberto o mecanismo de um sistema de dois componentes, um passo importante para o entendimento do comportamento e regulação bacteriana. Estes sistemas são geralmente compostos por uma proteína sensora contendo um domínio histidina quinase e uma proteína reguladora de resposta. Após receber um sinal, o sensor realiza auto-fosforilação e transmite um grupo fosfato para um resíduo presente no regulador de resposta cognato. A transdução de sinal é finalizada pela ação do regulador de resposta, que exerce a resposta efetora através de alterações na expressão de genes específicos. Muitas proteínas com domínios quinase contam com mais de um domínio sensor, assim como muitos reguladores de resposta apresentam mais de um domínio para a resposta efetora. A abundância de combinações deste sistema sugere que a transdução de sinais bacterianos seja considerada como uma rede composta de um grande número de domínios sensores que interagem com um grande número de domínios efetores (MARQUES, 2012). As proteínas sensoras recebem sinais intracelulares, ou, do ambiente, e os transmitem produzindo respostas variadas, promovendo mudanças na expressão de genes, níveis de mensageiros secundários, modificação de proteínas, e processos celulares que atuam no metabolismo e comportamento bacteriano (GALPERIN, GOMELSKY, 2005).

A transdução de sinais é um processo amplamente empregado por células bacterianas na regulação de diversos fenótipos e tem um papel central na comunicação por Quorum Sensing.

\subsection{Quorum Sensing}

A comunicação é uma habilidade aparentemente inerente aos organismos da Terra, logo, não é estranho pensar que bactérias são capazes de se comunicar umas com as outras. De fato, há aproximadamente 40 anos, dois grupos de pesquisa independentes fizeram relatos surpreendentes de bactérias que eram capazes de responder a sinais químicos produzidos por elas próprias para se comunicar e coordenar atividades em grupo. 
A bactéria Gram-positiva Streptococcus pneumoniae, o principal agente etiológico de infecções respiratórias (otites, sinusites e pneumonias), foi alvo de estudo por Tomasz e Hotchkiss (1964) para demonstrar o controle da expressão de fatores relacionados à competência genética. A presença de moléculas proteicas no sobrenadante, produzidas por $S$. pneumoniae, eram capazes de induzir um período de competência sincronizado em praticamente todas as células bacterianas da cultura. Posteriormente, Nealson, Platt e Hastings (1970) demonstraram que a interação simbiótica entre Vibrio fischeri e espécies marinhas que possuem órgãos de luz era baseada no controle da coordenação e expressão de bioluminescência bacteriana através do fenômeno de autoindução, envolvendo a produção de moléculas sinalizadoras pelas próprias bactérias.

Após anos sem um consenso entre cientistas sobre a existência de um sistema de comunicação bacteriano, em 1994 os autores Fuqua, Winans e Greenberg utilizaram o termo Quorum Sensing, nomenclatura proposta pelo cunhado de Winans, o qual fez uma analogia à situação bacteriana ao o que ocorre em reuniões sociais formais em que é necessário um número mínimo (quorum) de pessoas para que acordos sejam formalizados e sessões sejam iniciadas.

A definição de Quorum Sensing passou a ser determinada como o controle sincronizado da transcrição e expressão gênica em resposta à densidade celular, que atua na regulação de diversas funções fisiológicas relacionadas ou não à patogênese, e que envolve a produção e detecção de moléculas sinalizadoras denominadas autoindutores (AI) (BASSLER, 1999). Através deste sistema, as bactérias são capazes de alternar comportamentos e regular a expressão de genes em diferentes situações, em baixa densidade celular favorecendo comportamentos individuais, e em alta densidade celular induzindo comportamentos sociais (BASSLER, 1999). Este mecanismo funciona da seguinte maneira: inicialmente, moléculas sinalizadoras são sintetizadas intracelularmente e liberadas passivamente por difusão ou secretadas para o meio extracelular; em baixa densidade celular, a concentração dessas moléculas ainda não é suficiente para ser detectada; conforme o número de células da população bacteriana aumenta, a concentração extracelular de Al também aumenta; quando o acúmulo de Al alcança o nível necessário para sua detecção, essas moléculas se ligam a receptores específicos de membrana ou citoplasmáticos, disparando cascatas de sinalização que resultam em alterações na transcrição e expressão de genes-alvo na população. 
Anteriormente, acreditava-se que a "linguagem" bacteriana era específica a membros pertencentes à mesma espécie. Com o extensivo estudo deste sistema, o léxico da "linguagem" bacteriana tem se ampliado de forma significativa, e já foi demonstrado que a comunicação não se faz apenas de forma intraespecífica, mas também de forma interespecífica. É provável que a comunicação cruzada entre espécies diferentes seja mais comum do que a realizada entre bactérias da mesma espécie, levando em conta que na natureza as bactérias quase sempre ocorrem em populações mistas, como no caso dos biofilmes (BASSLER, 2003; ATKINSON, WILLIAMS, 2009; FEDERLE; FEDERLE, 2009; ANNOUS et al., 2009; LI, TIAN, 2012).

Até o momento, os sistemas que utilizam o autoindutor 1 (Al-1), Al-2, Al-3 e polipeptídeos autoindutores (AIP) são os mais estudados. Enquanto AIP parece ser utilizado principalmente por bactérias Gram-positivas, sinalizações por Al-1, Al-2 e AI-3 parecem estar envolvidas na comunicação intra e interespecífica em bactérias Gram-negativas e Gram-positivas (NG, BASSLER, 2009). Outros sistemas de Quorum Sensing foram identificados em uma grande variedade de espécies, como por exemplo, a família de sinais chamados diffusible signal factor (DSF) em Xanthomonas spp. e Burkholderia cenocepacia, cholera autoinducer-1 (CAl-1) em Vibrio spp. e Legionella pneumophila, Pseudomonas quinolone signal (PQS) em $P$. aeruginosa e um sistema baseado na produção de peptídeos pela bactéria Gramnegativa Thermotoga marítima (PESCI et al., 1999; JOHNSON et al., 2005; ; KELLY et al., 2009; DENG et al., 2011).

\subsubsection{Sistema LuxIR/AI-1}

O sistema LuxIR/Al-1 é um dos mecanismos mais bem caracterizados de Quorum Sensing. Baseia-se na utilização de moléculas chamadas acil homoserina lactona (AHL) como autoindutores. A comunicação por Al-1 parece ser específica para bactérias Gram-negativas e já foi relacionada à regulação da transferência plasmidial por conjugação, bioluminescência, síntese de antibióticos e diversos fatores de virulência (FUQUA, GREENBERG, 1998; PARSEK, et al., 1999). Descrito inicialmente no controle da bioluminescência por quorum em $V$. fischeri através de Luxl, uma proteína sintase produtora da molécula sinalizadora $\mathrm{N}$-3-oxohexanoyl-Lhomoserina lactona (3OC6-HSL) e LuxR, o ativador transcricional dos genes lux. A 
ligação de 30C6-HSL ao receptor LuxR ativa a transcrição do operon luxCDABEGH, cujo produto é a luciferase, enzima responsável pela luminescência (DEVINE et al., 1989). Com o surgimento das técnicas de sequenciamento e análise comparativa de sequências, pares de genes com homologia a luxR e luxl começaram a atrair a curiosidade de diversos pesquisadores. Isto levou à descoberta de inúmeras espécies bacterianas com sistemas do tipo luxI-IuxR (GRAY, GAREY, 2001). Foi estabelecido que homólogos a Luxl são responsáveis pela síntese de $\mathrm{AHL}$ e homólogos a LuxR são receptores com especificidade aos seus AHL cognatos.

As moléculas de AHL são formadas por um anel de $N$-acil homoserina lactona contendo uma cadeia lateral acil composta por 4 a 18 carbonos, com possíveis modificações no terceiro carbono (GALLOWAY et al., 2010). O tamanho da cadeia lateral acil pode afetar a estabilidade da molécula e acarretar em consequências na dinâmica de sinalização (von BODMAN et al., 2008). AHL produzidos são derivados da molécula precursora S-adenosilmetionina (SAM) e na maioria dos casos a cadeia lateral acil é obtida de intermediários de vias de biossíntese de ácidos graxos. A enzima LuxI (ou homólogos) catalisa as reações de acilação e lactonização entre os substratos, formando pontes amida entre a cadeia lateral acil e o grupamento amino de SAM (VAL, CRONAN, 1998). Uma vez alcançada a concentração necessária, as AHL são reconhecidas por proteínas do tipo LuxR, que apesar de não possuírem domínio transmembrânico, localizam-se na porção citoplasmática da membrana interna. Essas proteínas pertencem à família FixJ-NarL, cujos membros são, normalmente, reguladores de resposta de dois componentes que controlam a atividade de ligação ao DNA (KAHN, DITTA, 1991). Em todos os sistemas analisados, as AHL são sintetizadas a um baixo nível basal por AHL-sintases e são rapidamente removidas da célula por difusão pelo gradiente de concentração. A hidrofobicidade total da molécula permite que ela navegue pela camada bilipídica da membrana celular, assim como nos ambientes aquosos intra- e extracelulares. $O$ aumento da densidade populacional pode elevar a concentração local de AHL que, ao atingir uma concentração limite, interage com o fator de transcrição cognato à sua sintase, realizando a modulação da expressão de genes-alvo. Normalmente, os genes-alvo incluem o gene que codifica o homólogo a Luxl, criando um feedback positivo (STEWART, WILLIAMS, 1992).

As proteínas do tipo LuxR contém dois domínios funcionais, um domínio amino-terminal que tem papel na ligação de AHL e o domínio carboxi-terminal de 
ligação ao DNA (motivo helix-turn-helix) (SMITH et al., 2006). Na ausência do autoindutor cognato, receptores LuxR se rearranjam de maneira errônea e são degradados. Por outro lado, proteínas LuxR que se ligam a um autoindutor são estáveis, dimerizam-se e se ligam ao DNA-alvo (SWEM et al., 2009; ZHANG et al., 2002). Sua atividade regulatória se dá devido à ligação ou liberação de sequencias regulatórias específicas upstream aos genes-alvo (sequencias 'lux boxes'), normalmente seguido de ativação da transcrição (ENGEBRECHT et al., 1983; STEVENS et al., 1994). As estruturas de quatro sequências completas de receptores do tipo LuxR já foram demonstradas: TraR (Conjugal transfer) de Agrobacterium tumefaciens e Rhizobium sp. NGR234, QscR (quorum-sensing control repressor) e LasR (elastase transcriptional regulator) de $P$. aeruginosa e CviR ( $C$. violaceum receptor protein) de Chromobacterium violaceum (CHEN et al., 2007; LINTZ et al., 2011; CHEN et al., 2012).

Apesar de luxl/luxR ser um par de genes bastante conservado em diversas espécies bacterianas, espécies como $E$. coli e $S$. typhimurium não contém um gene homólogo a luxl, logo, não são capazes de produzir AHL (MICHAEL et al., 2001; AHMER, 2004). Porém, espécies como estas contém genes órfãos homólogos a luxR, como o gene sdiA que codifica a proteína receptora SdiA (Supressor of cell divison inhibitor), capaz de responder a $\mathrm{AHL}$ produzida por outras espécies bacterianas (AHMER, 2004). Inicialmente, SdiA foi identificado como um ativador da transcrição do operon ftsQAZ (cell division proteins), responsável por codificar proteínas essenciais para a divisão celular (WANG et al., 1991). Outros estudos sugeriram 0 envolvimento de SdiA em outras atividades celulares como metabolismo, motilidade, virulência, sobrevivência e mecanismos de defesa (KANAMARU et al., 2000; WEl et al., 2001; RAHMATI et al., 2002; VAN HOUDT et al., 2006; LEE et al., 2007).

Além de ser capaz de reconhecer AHL produzido por outras espécies bacterianas, o composto indol produzido por E. coli também foi proposto como um sinal para a ativação transcricional do promotor do gene ftsQ por SdiA (SITNIKOV et al., 1996). De acordo com diferentes estudos, indol serviria como um sinal interespecífico mediado por SdiA para controlar a formação de biofilme, ou como um fator inibitório da resposta por AHL (LEE et al., 2007; SABAG-DAIGLE et al., 2012). Estas evidências sugerem que SdiA possui um mecanismo intricado para 0 reconhecimento de diversos ligantes. $\mathrm{Na}$ maioria dos ambientes naturais as 
espécies bacterianas coexistem com outros micro-organismos, assim, a comunicação interespecífica por AHL ou outras moléculas sinalizadoras deve ter um papel importante, sinérgico ou competitivo, na dinâmica dessas comunidades microbianas (DUNNY, LEONARD, 1997; LAZAZZERA, 2000).

\subsubsection{Sistema LuxS/AI-2}

O sistema de Quorum Sensing que envolve a molécula sinalizadora do tipo Al-2 e sua sintase LuxS foi descrito em 1999 na espécie bacteriana marinha de vida livre Vibrio harveyi (SURETTE et al., 1999). Foi observado que a bactéria ainda era capaz de emitir luminescência apesar de uma mutação no gene luxl, impedindo a produção de Al-1. Isto levou os pesquisadores a supor que outro mecanismo regulatório estaria envolvido neste fenótipo. A produção do sinal Al-2 foi demonstrada como responsável pela ativação de luminescência (SCHAUDER, BASSLER, 2001; XAVIER, BASSLER, 2003). Depois dessa descoberta, o sistema LuxS/AI-2 foi detectado em um amplo número de bactérias Gram-positivas e Gramnegativas, o que sugeriu tratar-se de um modo de sinalização interespecífica (SCHAUDER et al., 2001; CHEN et al., 2002).

Assim como $\mathrm{Al}-1$, as moléculas de $\mathrm{Al}-2$ são liberadas pela bactéria, se acumulam no meio extracelular e quando atingem a concentração limiar para detecção, são reconhecidas por receptores de membrana que disparam uma cascata de sinalização intracelular, ativando ou reprimindo reguladores de resposta. Os genes que codificam a sintase, os receptores e os reguladores estão em operons distintos e são regulados e transcritos independentemente (TAGA et al., 2001; TAGA et al., 2003).

A informação mais importante para a elucidação da síntese de Al-2 resultou da análise da sequência genômica de Borrelia burgdorferi, que demonstrou que o gene luxS é o terceiro de um operon que contém os genes pfs e metK, que codificam enzimas envolvidas em uma via metabólica importante de reciclagem de SAM, principal doador de metil para as atividades celulares, como metilação de moléculas de DNA e RNA, proteínas e metabólitos. A liberação do grupo metil de SAM gera um intermediário tóxico para a célula, a S-adenosil homocisteína (SAH), convertida por Pfs em S-ribosil homocisteína $(\mathrm{SRH})$, que constitui o substrato para a enzima LuxS. LuxS catalisa a clivagem de SRH gerando homocisteína e liberando o 
subproduto 4,5- dihidroxi-2,3-pentanediona (DPD) (SCHAUDER et al., 2001). DPD é uma molécula muito instável, que se cicliza espontaneamente em diferentes isômeros quando em solução. Na verdade, o termo Al-2 descreve um grupo de furanonas derivadas da molécula DPD que, na presença de água, são capazes de se rearranjar e se interconverter espontaneamente em diferentes formas de $\mathrm{Al}-2$ (SCHAUDER et al., 2001; WINZER et al., 2002; SPERANDIO et al., 2003).

Até o momento, dois tipos de receptores específicos para Al-2 foram bem caracterizados, LuxP e LsrB (LuxS regulated). Esses receptores foram descritos inicialmente em $V$. harveyi e $S$. Typhimurium, respectivamente, e são classificados por sua capacidade de se ligar a moléculas quimicamente distintas de DPD (CHEN et al., 2002; MILLER et al., 2004). Alguns estudos demonstraram que membros da família de proteínas ligadoras de ribose (RbsB) também são capazes de reconhecer Al-2 (JAMES et al., 2006; SHAO et al., 2007). Além disso, algumas bactérias que não possuem nenhum dos três tipos de receptor citados são capazes de responder ao Al-2, sugerindo a possibilidade de haver outros receptores ainda não descritos (REZZONICO, DUFFY, 2008).

Em $V$. harveyi, a molécula sinalizadora Al-2 é reconhecida por um sistema de dois componentes, LuxPQ. O Al-2 é detectado por LuxP, uma proteína periplasmática com alta afinidade ao substrato, e o complexo Al-2/LuxP interage com o sensor histidina quinase $L u x Q$, iniciando uma cascata de transferência de fosfato que envolve as proteínas $\mathrm{LuxU}$ e $\mathrm{LuxO}$, que ativam o regulador transcricional LuxR, resultando na produção de luciferase e na luminescência (BASSLER et al., 1994). O sistema LuxPQ/Al-2 já foi descrito em outras espécies como $V$. cholerae e $V$. vulnificus participando da regulação de diversos fenótipos. Porém, até o momento, receptores do tipo LuxP foram encontrados apenas em membros da ordem Vibrionales (MIYAMOTO et al., 2000; MAKINO et al., 2003; CHEN et al., 2003; SUN et al., 2004; KASAI, 2006).

Receptores do tipo LsrB também são proteínas periplasmáticas de alta afinidade ao substrato que reconhecem moléculas de AI-2, porém, possuem baixa homologia a LuxP (11\% de similaridade) (PEREIRA et al., 2009). Diferente de LuxP, LsrB já foi descrito em uma ampla gama de espécies patogênicas e simbiontes como E. coli, S. Typhimurium e Sinorhizobium meliloti. Nessas espécies, o mecanismo de detecção do Al-2 ocorre através do sistema Lsr (TAGA et al., 2003; XAVIER, BASSLER, 2005; PEREIRA et al., 2008). O operon Isr codifica um sistema 
de transporte do tipo ABC. O Al-2 é reconhecido pela proteína receptora LsrB e, em seguida, transportado para o interior da célula pelo canal formado por LsrC e LsrD com auxílio de LsrA, responsável pela hidrólise de ATP durante o transporte. Uma vez dentro da célula, o Al-2 é fosforilado pela proteína quinase LsrK e processado pelas enzimas LsrG e LsrF. Acredita-se que a forma fosforilada de Al-2 interaja com a proteína repressora LsrR, promovendo a transcrição do operon Isr. O aumento da transcrição e expressão de Lsr faz com que a importação de Al-2 aumente, resultando em uma rápida depleção da molécula sinalizadora do meio extracelular (TAGA et al., 2003).

Já foram identificados homólogos da proteína LuxS em mais de 500 espécies de enterobactérias e mais de 2600 espécies bacterianas e, apesar da sintase e da via biossintética que produzem o precursor do Al-2 serem iguais em todas elas, a molécula que é realmente detectada pelas diferentes espécies pode ser diferente (PEREIRA et al., 2013). A cristalização do complexo LuxP-ligante de V. harveyi permitiu a identificação da primeira molécula com atividade de Al-2, caracterizada como uma furanona boratada derivada de SAM. Essa foi a primeira vez que o Boro foi associado a uma atividade biológica (CHEN et al., 2002). Já na cristalografia do complexo LsrB-ligante de Salmonella foi identificada uma outra molécula de Al-2, caracterizada como uma furanona não boratada derivada de SAM. Essa diferença pode depender principalmente do ambiente em que as bactérias se encontram (MILLER et al., 2004). Em ambientes marinhos, ricos em Boro, o DPD pode se converter na forma boratada e no solo ou dentro do hospedeiro, em formas nãoboratadas.

Já foi demonstrado que Al-2 é um produto comumente sintetizado por bactérias comensais do TGI. Se a molécula de Al-2 é um produto de metabolismo destas bactérias e/ou se estão envolvidos em sinalização célula-célula ainda não foi elucidado. (LUKÁS et al., 2008). A bactéria comensal de humanos Blautia obeum recentemente foi identificada por ter papel na inibição da colonização do intestino de ratos por $V$. cholerae, parcialmente por sinalização via Al-2, demonstrando como a produção de Al-2 por bactérias comensais pode afetar patógenos invasores (HSIAO et al., 2014). A sinalização por Al-2 aumenta a formação de biofilme e colonização do hospedeiro por Bifidobacteria (GRIMM et al., 2014). Estes micro-organismos são um grupo importante da microbiota humana sadia e algumas amostras foram capazes de conferir resistência contra a colonização de patógenos entéricos como 
EHEC e C. rodentium em modelos murinos (FUKUDA et al., 2011; FANNING et al., 2012). A expansão de bactérias comensais do filo Firmicutes em sobreposição à Bacteroidetes no TGI após tratamento com antibiótico foi atribuída à sinalização por Al-2, sugerindo um papel do Quorum Sensing na composição da microbiota (THOMPSON et al., 2015).

Vários papeis na sinalização célula-célula tem sido atribuídos ao Al-2, como produção de proteases em Streptococcus pyogenes e regulação do ativador transcricional VirB dos genes de invasão de Shigella flexneri (LYON et al., 2001; DAY, MAURELLI, 2001). Porém, esse gene tem ação pleiotrópica e parece estar envolvido na regulação de diversas funções fisiológicas básicas, incluindo divisão celular, motilidade, genes envolvidos no metabolismo, assim como mecanismos de virulência (MAROUNI, SELA, 2003; DOMKA et al., 2006; GONZÁLEZ-BARRIOS et al., 2006; HERZBERG et al., 2006). Desta forma, a deleção de luxS pode resultar em fenótipos complexos, muitas vezes mascarados ou até mesmo ressaltados por alterações metabólicas. No entanto, apesar de alguns pesquisadores ainda defenderem que o Al-2 é apenas um subproduto do metabolismo bacteriano, seu papel como molécula sinalizadora de Quorum Sensing já está bem estabelecido em algumas espécies. Devido ao seu papel na reciclagem de produtos do metabolismo de SAM, foi sugerido que a pressão seletiva para manter luxS no genoma era primariamente para remover compostos prejudiciais à célula e reciclar os produtos do metabolismo de SAM (SCHAUDER et al., 2001; WINZER et al., 2003). Brito e colaboradores (2012) relataram que uma amostra de E.coli mutante em pfs apresenta crescimento celular comprometido, provavelmente devido ao acúmulo de $\mathrm{SAH}$. Interessantemente, neste mesmo trabalho, os autores não observaram diferenças marcantes no metabolismo de E. coli mutante em luxS. Isto indica que Pfs, e não LuxS, é a enzima de maior importância para prevenir as consequências tóxicas causadas pelo acúmulo de $\mathrm{SAH}$, reforçando a ideia de que a pressão seletiva de manter o gene luxS funcional no genoma não é de característica metabólica, e sim social (BRITO et al., 2012).

\subsubsection{Sistema QseBC/AI-3}

O sistema de Quorum Sensing que se baseia na molécula sinalizadora Al-3 é o menos conhecido. Foi descrito primeiramente na regulação de motilidade e 
expressão do flagelo em EHEC e depois se mostrou participar da regulação de outros fatores de virulência deste patógeno, incluindo a expressão da toxina de Shiga (SPERANDIO et al., 2002; SPERANDIO et al., 2009).

Anteriormente, acreditava-se que Al-2 fizesse parte do sistema de Quorum Sensing regulatório da região LEE em EHEC pela ativação do sistema de dois componentes QseBC (quorum-sensing E.coli regulator B and C) (SPERANDIO et al., 2002). Porém, após a avaliação de estudos utilizando mutantes em luxS, revelou-se que o sobrenadante do meio de cultura dessas amostras continha alguma substância capaz de ativar a expressão de LEE e incapaz de emitir bioluminescência em amostras repórteres de sinalização por Al-2 (SPERANDIO et al., 2003). A estrutura e a síntese da molécula sinalizadora ainda são desconhecidas, mas acredita-se tratar de um composto aromático semelhante a hormônios eucarióticos da família das catecolaminas. Quimicamente distinto de Al-2, Al-3 é menos polar e se liga à colunas $\mathrm{C}_{18}$ e é apenas eluído por metanol (SPERANDIO et al., 2003). Apesar de incerta, a sinalização celular por Al-3 já foi detectada experimentalmente em diversas espécies da família Enterobacteriaceae, inclusive por espécies comensais do TGI (WALTERS et al., 2006).

A detecção de Al-3 ocorre através do sistema de dois componentes QseBC. $\mathrm{Na}$ presença de Al-3 em alta concentração no periplasma, a proteína sensora QseC sofre auto-fosforilação e transfere o fosfato para o regulador de resposta QseB, iniciando uma complexa cascata de sinalização que culmina na transcrição de genes-alvo. Homólogos a QseC já foram identificados em diferentes espécies Gramnegativas comensais e patogênicas (CLARKE et al., 2006). Um fator desconhecido produzido por células HeLa foi associado à complementação de amostras deficientes na produção de Al-3 em relação a ativação da região LEE via QseBC (CLARKE et al., 2006). Apesar das células bacterianas não produzirem receptores adrenérgicos, muitos estudos indicam que elas respondem a epinefrina e norepinefrina no TGI, onde estes hormônios estão presentes (LYTE, 1992; SPERANDIO et al., 2003; FREESTONE et al., 2003; CLARKE, SPERANDIO, 2005). Acredita-se que patógenos bacterianos utilizem o sensor quinase QseC para reconhecer, além do sinal bacteriano $\mathrm{Al}-3$, esses sinais adrenérgicos derivados do hospedeiro para ativar a transcrição de genes de virulência, uma vez que Al-3, epinefrina e norepinefrina são moléculas agonistas e sua ação pode ser bloqueada por antagonistas adrenérgicos (SPERANDIO et al., 2003). Estes dados demonstram 
que tanto Al-3 e/ou epinefrina/norepinefrina são reconhecidos pelo mesmo receptor.

Além de QseB, foi demonstrada a fosforilação por QseC de dois reguladores de resposta não cognatos. QseF é um regulador de resposta que tem como sensor cognato a proteína QseE, um receptor adrenérgico. A ativação de QseF por QseC indica a existência de uma conversa cruzada entre diferentes sistemas de dois componentes relacionados a catecolaminas (READING et al., 2009). KdpE é outro regulador de resposta que além de ser ativado por seu sensor cognato $\mathrm{KdpD}$, também é ativado por QseC. A regulação de KdpE por KdpD ocorre através de mudanças na osmolaridade e na utilização de diversos metabólitos na célula bacteriana (HUGHES et al., 2009). O sistema QseBC participa da regulação de fenótipos complexos como formação de biofilme e motilidade (NOVAK et al., 2010; JUAREZ-RODRIGUEZ et al., 2014).

\subsection{Comunicação inter-reinos}

Ao longo dos anos a coevolução entre eucariotos e procariotos fez com que organismos de Reinos distintos sejam expostos a diferentes tipos de sinalizações. A capacidade de sentir moléculas produzidas por organismos de outros reinos, inclusive moléculas $\mathrm{Al}$, foi desenvolvida no decorrer desta interação duradoura (PACHECO, SPERANDIO, 2009; GONZALEZ, VENTURI, 2013). Processos de sinalização inter-reinos entre micro-organismos e seus hospedeiros são centrais em um campo de estudo emergente chamado "endocrinologia microbiana" (LYTE, 1993; LYTE, ERNST, 1993).

Uma hipótese interessante para a existência de um receptor adrenérgico como QseC em bactérias seria a utilização de hormônios produzidos pelo hospedeiro como sinais para bactérias patogênicas ativarem genes de virulência em condições oportunas (HUGHES, SPERANDIO, 2008). Norepinefrina induz 0 crescimento bacteriano e a expressão de fímbrias e toxinas em amostras de $E$. coli patogênicas (LYTE, 1992; LYTE et al., 1997; BURTON et al., 2002). Este hormônio é liberado principalmente para adaptar a célula mamífera a situações de estresse. A capacidade de bactérias sentirem este sinal oferece uma vantagem para organismos patogênicos medirem o estado metabólico do hospedeiro e tirar vantagem de um sistema imunológico vulnerável (MOLINA, 2006). A evolução desse sistema sofisticado permite a modulação da transdução de sinais célula-célula e a 
comunicação cruzada entre hormônios derivados do hospedeiro e sinalização por Quorum Sensing, regulando a expressão gênica da bactéria em determinadas ocasiões (TELFORD et al., 1998; SPERANDIO et al., 2003).

$\mathrm{AHL}$ produzidas por bactérias também podem interagir com células de mamíferos, apesar de não ter sido encontrado um receptor para este Al neste tipo de célula (WILLIAMS et al., 2004). A primeira interação deste gênero foi identificada pela observação do aumento de interleucina-8 em células do epitélio respiratório de acordo com o aumento de AHL purificado adicionado ao meio (DIMANGO et al., 1995). Estudos posteriores indicaram que $A H L$ tem um efeito pleiotrópico na célula do hospedeiro, dependendo do tipo de célula afetada, concentração de AHL e condições testadas. Devido à interação entre $A H L$ e hospedeiro ser na maioria das vezes uma resposta do sistema imune, afetando diversas vias de sinalização, estas interações provavelmente não são de natureza patogênica. Como um modo de defesa contra essas moléculas, os humanos desenvolveram a habilidade de destruir AHL através de enzimas chamadas paraoxanases (AMARA et al., 2011).

Interessantemente, Ismail e colaboradores (2016) relataram a produção de uma molécula com propriedades semelhantes a Al-2 por células eucarióticas. Utilizando células mamíferas de origem epitelial, os autores deste estudo identificaram a produção de um análogo a Al-2 em co-cultura com espécies bacterianas como $V$. harveyi, E. coli e $S$. typhimurium. A produção desta molécula parece ser realizada apenas em condições de estresse celular e na presença de bactéria no meio de cultura. Os autores sugeriram que é necessária a produção de algum componente bacteriano para a produção do análogo de Al-2. Observando um aumento da produção deste análogo após danos nas junções oclusivas do epitélio, foi proposto um papel no reparo epitelial promovido por bactérias comensais que sentem esta molécula. A produção de uma molécula análoga a Al-2 pode ser uma estratégia criada pelo hospedeiro para manipular o comportamento bacteriano em populações heterogêneas como as que existem no TGI.

\subsection{Quorum Sensing em E.coli}

A sinalização por Quorum Sensing em E. coli já foi relacionada aos mais diversos processos celulares. O gene sdiA está envolvido na colonização do intestino de bovinos, na regulação da formação de biofilme e na transcrição de 
genes relacionados a motilidade em EHEC (SPERANDIO, 2010; SHARMA et al., 2010). A sinalização baseada no sistema QseBC controla a transcrição de genes da região LEE, assim como de genes de biossíntese flagelar e pode ter um papel importante na patogenicidade (HUGHES et al., 2009; KOSTAKIOTI et al., 2009; SPERANDIO et al., 2012). O gene luxS e a sinalização por Al-2 já foram relacionados à formação de biofilme, motilidade e modulação da colonização da microbiota intestinal (GONZÁLEZ-BARRIOS et al., 2006; KENDALL et al., 2007; NIU et al., 2012; HSIAO et al., 2014).

Fatores de virulência como formação de biofilme, motilidade e adesão ao epitélio do hospedeiro devem ser controlados de maneira adequada para tirar o melhor proveito da situação em que a bactéria se encontra. Para que E. coli se adapte ao ambiente em que está inserida, dentro ou fora do hospedeiro, é vital que seja realizada uma avaliação da situação do meio extracelular, convertendo a informação em respostas rápidas. Deste modo, faz-se necessário descobrir de forma detalhada como os diversos mecanismos de sinalização respondem aos diferentes sinais, e mais ainda, se existe uma forma de hierarquia e intercomunicação entre estes sistemas de regulação de tipos distintos. 


\section{OBJETIVO}

Analisar a influência e a correlação dos genes luxS, qseC e sdiA, relacionados ao sistema de comunicação bacteriana Quorum Sensing, sobre processos envolvidos na infecção e adaptação de uma amostra de EPEC atípica de origem animal. 


\section{MATERIAL E MÉTODOS}

\subsection{Amostras bacterianas e plasmideos}

Neste estudo, foi utilizada a amostra de EPEC atípica de origem animal pertencente ao sorotipo $0111: \mathrm{H} 25$, gentilmente cedida pelo Prof. Dr. Antonio Fernando Pestana de Castro (in memorian). As amostras AP155 mutante em luxS e AP155 mutante luxS complementada foram gentilmente cedidas pela Dra. Vanessa Bueris. O plasmídeo pKD46 envolvido no sistema de recombinação lambda red foi utilizado para realizar os eventos de recombinação homóloga, assim como o plasmídeo helper pCP20. Os plasmideos pKD3 e pKD4 serviram como molde para a amplificação de genes de resistência aos antibióticos cloranfenicol e canamicina, respectivamente. Para a complementação de amostras mutantes foram utilizados os plasmideos pVS155 e pHFC01. As informações de todas as amostras e plasmídeos utilizados neste estudo estão descritas na Tabela 1.

\subsection{Meios de cultura e soluções}

Os meios de cultura utilizados para o cultivo e manutenção das amostras bacterianas e celulares, assim como as soluções empregadas nas diversas técnicas descritas a seguir, foram preparados de acordo com Sambrook, Fritsch e Maniatis (1989), ou conforme as recomendações do fabricante.

As moléculas autoindutoras foram preparadas como descrito a seguir. Al-1: a $\mathrm{N}$-acil homoserina lactona $\mathrm{N}$-(3-Oxohexanoyl)-DL-homoserina lactona (30-C6-DLHSL) (Sigma-Aldrich, EUA) foi diluída em DMSO na concentração de 1 mM (Solução estoque) e mantida a $-20{ }^{\circ} \mathrm{C}$. A concentração final da $\mathrm{AHL}$ utilizada nos experimentos foi de $2 \mu \mathrm{M}$. Al-2: o composto 4-hidroxi-5-metil-3(2H)-furanona (MHF) é o principal produto formado após a solubilização de 4,5-dihidroxi-2,3-pentanediona (DPD), apresentando atividade de Al-2 in vitro. MHF foi diluído em água destilada em uma concentração estoque de $1 \mathrm{M}$ e adicionado em uma concentração final de $100 \mu \mathrm{M}$ para os ensaios fenotípicos. O hormônio epinefrina (Sigma-Aldrich, EUA) foi diluído em água destilada a fim de se obter a concentração final de $50 \mu \mathrm{M}$ para cada experimento. 
Tabela 1: Linhagens bacterianas e plasmídeos utilizados nesse estudo.

\begin{tabular}{|c|c|c|}
\hline Amostras e Plasmídeos & Descrição & Fonte \\
\hline \multicolumn{3}{|l|}{ Amostras } \\
\hline AP155 WT & EPECa O111:H25 selvagem & NAKAZATO et. al. (2004) \\
\hline AP155 $\Delta / u x S$ & AP155 com deleção em luxS & Dados não publicados \\
\hline AP155 $\Delta / u x S^{+}$ & $\begin{array}{l}\text { AP155 com deleção em luxS albergando o plasmideo } \\
\text { pVS84 }\end{array}$ & Dados não publicados \\
\hline AP155 $\Delta q s e C$ & AP155 com deleção em qseC & Este estudo \\
\hline AP155 $\Delta q s e C^{+}$ & $\begin{array}{l}\text { AP155 com deleção em qseC albergando o plasmideo } \\
\text { pVS155 }\end{array}$ & Este estudo \\
\hline AP155 $\Delta$ sdiA & AP155 com deleção em sdiA & Este estudo \\
\hline AP155 $\Delta s d i A^{+}$ & $\begin{array}{l}\text { AP155 com deleção em sdiA albergando o plasmideo } \\
\text { pHFC01 }\end{array}$ & Este estudo \\
\hline AP155 $\Delta q s e C / l u x S$ & AP155 com deleção em qseC e luxS & Este estudo \\
\hline AP155 $\Delta q s e C / l u x S / s d i A$ & AP155 com deleção em qseC, luxS e sdiA & Este estudo \\
\hline BW 25113 & E. coli K12 albergando o plasmídeo pKD46 & $\begin{array}{l}\text { DATSENKO, WANNER, } \\
2000\end{array}$ \\
\hline BW 25141 & E. coli K12 albergando o plasmídeo pKD3 & $\begin{array}{l}\text { DATSENKO, WANNER, } \\
2000\end{array}$ \\
\hline BW 25141 & E. coli K12 albergando o plasmídeo pKD4 & $\begin{array}{l}\text { DATSENKO, WANNER, } \\
2000\end{array}$ \\
\hline pHFC01 & Vetor de expressão pBADMycHisA + sdiA & CULLER, 2015 \\
\hline pVS155 & Vetor de expressão pBADMycHisA +qseC & SPERANDIO et al., 2002 \\
\hline pKD3 & $\begin{array}{l}\text { Molde para a amplificação do cassete de recombinação de } \\
\text { canamicina (cat) (Sistema } \lambda \text { - Red) }\end{array}$ & $\begin{array}{l}\text { DATSENKO, WANNER, } \\
2000\end{array}$ \\
\hline pKD4 & $\begin{array}{l}\text { Molde para a amplificação do cassete de recombinação de } \\
\text { cloranfenicol (kan) (Sistema } \lambda \text { - Red) }\end{array}$ & $\begin{array}{l}\text { DATSENKO, WANNER, } \\
2000\end{array}$ \\
\hline pKD46 & $\begin{array}{l}\text { Plasmídeo auxiliar contendo os genes das enzimas de } \\
\text { recombinação (sistema } \lambda \text { - Red) }\end{array}$ & $\begin{array}{l}\text { DATSENKO, WANNER, } \\
2000\end{array}$ \\
\hline pCP20 & $\begin{array}{l}\text { Plasmídeo auxiliar contendo os genes das enzimas de } \\
\text { recombinação (sistema } \lambda \text { - Red) }\end{array}$ & $\begin{array}{l}\text { DATSENKO, WANNER, } \\
2000\end{array}$ \\
\hline
\end{tabular}

Kan - gene de resistência à canamicina; cat (cloranfenicol acetiltransferase) - gene de resistência ao cloranfenicol 
Foram realizados ensaios com e sem a adição de autoindutores exógenos no meio de cultura a fim de avaliar seus efeitos nos fenótipos estudados. A amostra selvagem recebeu alternadamente os compostos 30-C6-DL-HSL, DPD e epinefrina. Experimentos utilizando as amostras $\Delta / u x S$ e $\Delta / u x S^{+}$foram acrescidos de MHF. O composto 3o-C6-DL-HSL foi adicionado na presença das amostras $\Delta s d i A$ e $\Delta s d i A^{+}$. Adrenalina foi utilizada em experimentos com as amostras $\Delta q s e C$ e $\Delta q s e C^{+}$. A amostra mutante duplo recebeu alternadamente MHF e epinefrina, enquanto a amostra triplo mutante foi testada com os três compostos.

\subsection{Detecção dos genes luxS, qseC e sdiA}

A presença dos genes luxS, qseC e sdiA foi verificada através de Reação em Cadeia da Polimerase (PCR), utilizando iniciadores específicos descritos na literatura (Tabela 2). As amostras foram enviadas para sequenciamento no Centro de Estudos do Genoma Humano - USP, e foram preparadas de acordo com o sistema MegaBACE 1000, utilizando o DYEnamic ET Dye Terminator Kit (com Thermo Sequenase ${ }^{\mathrm{TM}}$ // DNA Polimerase). As sequências nucleotídicas foram analisadas pelo software Bioedit, utilizando o Base Caller Cimarron 3.12.

\subsubsection{Reações em Cadeia da Polimerase (PCR)}

Para cada reação foram utilizados 25 pmol de cada um dos iniciadores, $1 \mathrm{U}$ de Taq DNA-Polimerase (Invitrogen, EUA), 1,5 mM de cloreto de magnésio, $200 \mu \mathrm{M}$ da mistura de dNTPs (dATP, dCTP, dGTP e dTTP), 2,5 $\mu$ do tampão de reação de PCR 10x concentrado (Invitrogen). Como DNA molde foram utilizados $2 \mu$ dos lisados bacterianos: uma alçada do crescimento bacteriano em ágar Luria Bertani (LBA) foi ressuspensa em $300 \mu$ de água estéril e submetida à fervura durante 10 min e imediatamente colocada no gelo.

\subsubsection{Eletroforese de DNA em gel de agarose}

Após as reações de amplificação por PCR, as amostras foram submetidas à eletroforese em gel de agarose. Os géis foram preparados por aquecimento, fundindo-se agarose (Invitrogen, EUA) em tampão TAE 1x preparado a partir da 
solução estoque TAE 50x (tris base $242 \mathrm{~g}$; ácido acético glacial $57,1 \mathrm{~mL}$; ácido etilenodiaminotetracético [EDTA] 0,5 M $100 \mathrm{~mL}$ ) em concentração final de $1 \%$. Os fragmentos de DNA resultantes das PCRs foram acrescidos de tampão de amostra 1 X (azul de bromofenol 0,25\%; xileno cianol 0,25\%; glicerol 30\%). Como marcador de peso molecular foi utilizado o $1 \mathrm{~kb}$ Plus DNA Ladder (Invitrogen, EUA). Após a corrida eletroforética realizada sob corrente constante de $75 \mathrm{~V}$ em tampão TAE $1 \mathrm{X}$, os géis foram corados em solução de brometo de etídio na concentração de $5 \mu \mathrm{g} / \mathrm{ml}$ durante 10 a 20 min e em seguida observados em transiluminador de luz ultravioleta.

\subsubsection{Purificação dos fragmentos}

Após a eletroforese, a purificação dos fragmentos foi realizada seguindo o protocolo do Illustra ${ }^{T M}$ GFX ${ }^{T M}$ PCR DNA and Gel Band Purification Kit (GE Healthcare) e quantificado através do marcador Low DNA Mass Ladder (Invitrogen).

\subsection{Obtenção de mutantes em luxS, qseC e sdiA}

A construção dos mutantes em luxS, qseC e sdiA foi realizada pela metodologia descrita por Datsenko e Wanner (2000), baseada na recombinação homóloga mediada pelo sistema Lambda Red. Este método envolve a ação do plasmídeo pKD46 que possui um sistema de recombinação alélica proveniente do bacteriófago Lambda. Três genes estão envolvidos neste sistema: exo, bet e gam. A transcrição destes genes está sob controle de um promotor de arabinose, que é constitutivamente reprimido e apenas ativado na presença deste açúcar no meio de cultura. Este controle rigoroso impede que eventos de recombinação indesejados ocorram em condições em que não há indução. A proteína Gam inibe as exonucleases $V$ do sistema de recombinação RecBCD do hospedeiro para que as proteínas Bet e Exo promovam a recombinação pelo acesso à extremidades do DNA (DATSENKO, WANNER, 2000). Exo cliva o DNA na extremidade 5' criando extremidades 3' livres na fita complementar, Bet se liga à essa região protegendo-a de possível degradação por enzimas e facilita a recombinação por promover o anelamento à regiões homólogas no cromossomo da bactéria (MOSBERG et al., 2010). Os plasmídeos acessórios pKD3 e pKD4 albergam os genes de resistência aos antibióticos cloranfenicol e canamicina, respectivamente, flanqueados por sítios 
FRT. Este plasmídeo foi utilizado como molde para a amplificação dos cassetes de recombinação. O plasmídeo $\mathrm{pCP20}$ é utilizado para remover o cassete de resistência inserido na amostra mutante. Este plasmídeo tem replicação sensível a altas temperaturas e realiza a síntese de FLP a $30^{\circ} \mathrm{C}$. O sistema FLP tem como alvo os sítios FRT, que flanqueiam os cassetes de resistência amplificados nos plasmídeos pKD3 e pKD4. Como molde para a amplificação do cassete de recombinação foram utilizados os plasmídeos pKD3, que contém o gene cat, e pKD4, que confere resistência ao antibiótico canamicina pela expressão de kan. A resistência ao antibiótico promovida pelo cassete integrado ao cromossomo foi removida por enzimas expressas no plasmídeo pCP20 transformado na bactéria mutante. Após a retirada do gene cat, a amostra foi submetida a um novo evento de recombinação homóloga em outro gene de interesse.

\subsubsection{Extração plasmidial}

Os plasmídeos utilizados neste estudo (Tabela 1) foram extraídos através de lise alcalina com o WizardTM Plus SV Miniprep DNA Purification System (Promega Co. EUA), segundo instruções do fabricante.

\subsubsection{Obtenção de células eletrocompetentes}

Células eletrocompetentes foram preparadas conforme o protocolo a seguir: a amostra O111:H25 foi previamente cultivada em $3 \mathrm{~mL}$ de caldo Luria- Bertani (LB) durante $18 \mathrm{~h}$ a $37^{\circ} \mathrm{C}$, sob agitação constante de $300 \mathrm{rpm}$. Uma alíquota de 2,5 mL desse pré-inóculo foi transferida pra $250 \mathrm{~mL}$ de caldo LB e essa cultura foi cultivada sob as mesmas condições anteriores até atingir a absorbância de 0,5 a 0,6 em comprimento de onda de $600 \mathrm{~nm}$. As células bacterianas foram então incubadas em banho de gelo por 15 min, transferidas para um tubo de centrifugação pré-resfriado e então centrifugadas por $20 \mathrm{~min}$ a $5.000 \mathrm{~g}$ sob temperatura de $4{ }^{\circ} \mathrm{C}$. O sobrenadante foi desprezado e o material sedimentado foi lavado duas vezes com $250 \mathrm{~mL}$ de água MilliQ estéril resfriada a $4{ }^{\circ} \mathrm{C}$. As células foram cuidadosamente ressuspensas em $30 \mathrm{~mL}$ de glicerol $10 \%$ resfriado a $4{ }^{\circ} \mathrm{C}$ e centrifugadas a $5.000 \mathrm{~g}$ por 10 min sob temperatura de $4^{\circ} \mathrm{C}$. Adicionou-se, então, ao sedimento bacteriano $300 \mu \mathrm{L}$ de solução de glicerol $10 \%$ resfriado a $4{ }^{\circ} \mathrm{C}$ para ressuspender gentilmente 
as células bacterianas. Essa suspensão foi aliquotada em volumes de $50 \mu \mathrm{L}$ em tubos de polipropileno previamente resfriados e imediatamente congeladas a $80{ }^{\circ} \mathrm{C}$ negativos.

\subsubsection{Eletrotransformação}

As células competentes foram descongeladas em banho de gelo e a cada alíquota foram adicionadas 100-200 ng do DNA a ser transformado. Em seguida, foram transferidas para cubetas apropriadas de 0,2 cm (Biorad, EUA), previamente resfriadas, e submetidas à eletroporação utilizando o E.coli Pulser (Biorad), sob as condições de 2,5 kV, $25 \mu \mathrm{F}$ e controle de pulso a $200 \Omega$. Após a eletroporação, foi adicionado imediatamente $1 \mathrm{~mL}$ de meio SOC (triptona $2 \%$; extrato de levedura 0,5\%; cloreto de sódio $10 \mathrm{mM}$; cloreto de potássio $2,5 \mathrm{mM}$; sulfato de magnésio 20 mM; cloreto de magnésio $10 \mathrm{mM}$; glicose $20 \mathrm{mM}$ ) à reação e esta foi incubada a 37 @C durante $1 \mathrm{~h}$ sob agitação de 300 rpm. Em seguida, o cultivo foi semeado em ágar LB contendo o antibiótico de resistência para seleção dos transformantes e, em seguida, incubado a $37^{\circ} \mathrm{C}$ por $18 \mathrm{~h}$.

\subsubsection{Confirmação da mutação}

A mutação, assim como a análise da fase de leitura da open reading frame (ORF) modificada foi confirmada através de PCR e pelo sequenciamento dos fragmentos obtidos, como descrito no item 4.3. 
Tabela 2. Sequência dos iniciadores utilizados neste estudo, tamanho dos fragmentos obtidos e ciclo de amplificação para cada gene.

\begin{tabular}{|c|c|c|c|c|}
\hline Iniciadores & Sequências (5'- 3') & $\begin{array}{l}\text { Tamanho } \\
\text { do } \\
\text { fragmento } \\
\text { (pb) }\end{array}$ & Ciclo de Amplificação & Referência \\
\hline sdiA-DT & $\begin{array}{l}\text { F-CAGTAGCGGCCGCGTAACA } \\
\text { R- GAGAATGCGATGGCTTGCAAAAG }\end{array}$ & $\begin{array}{c}840^{\star}, 1196^{*} \\
1700^{*}\end{array}$ & $\begin{array}{c}1 \min 94^{\circ} \mathrm{C}, 1 \min 60^{\circ} \mathrm{C}, 1 \\
\min 72^{\circ} \mathrm{C}(30 \mathrm{x}) ; 8 \min 72 \\
{ }^{\circ} \mathrm{C}\end{array}$ & Culler, 2015 \\
\hline sdiA-DL & $\begin{array}{c}\text { F-AGCAACCTGCGTCTTATTCGGTGCATTGATTTTTTTCTGCG } \\
\text { TGTAGGCTGGAGCTGCTTC } \\
\text { R- TATCATTATAAATGATACTCACTCTCAGGGGCGTTGCGGT } \\
\text { GAACTAAGGAGGATATTCATATG }\end{array}$ & $\begin{array}{l}1094^{*}(\mathrm{pKD} 3) \\
1659^{*}(\mathrm{pKD} 4)\end{array}$ & $\begin{array}{c}1 \min 94^{\circ} \mathrm{C}, 1 \min 50^{\circ} \mathrm{C}, 1 \\
\min 72^{\circ} \mathrm{C}(30 \mathrm{x}) ; 8 \min 72 \\
{ }^{\circ} \mathrm{C}\end{array}$ & Culler, 2015 \\
\hline$q s e C-D T$ & $\begin{array}{l}\text { F- GCAAACTCGGCAGTGATTTT } \\
\text { R-ACAGAGCGGTACGGTGAAAT }\end{array}$ & $2065^{*}, 1141^{*}$ & $\begin{array}{l}1 \min 94^{\circ} \mathrm{C}, 1 \min 60^{\circ} \mathrm{C}, 1 \\
\min 72^{\circ} \mathrm{C}(30 \mathrm{x}) ; 8 \min 72 \\
{ }^{\circ} \mathrm{C}\end{array}$ & Culler, 2015 \\
\hline$q s e C-D L$ & $\begin{array}{l}\text { F- TTCGTACCGTTCATGGTATTGGCTACACATTAGGTGAGAA } \\
\text { GTGTAGGCTGGAGCTGCTTC } \\
\text { R- ATGTGCAAAGTCTTTTGCGAATTAGCAAAATCTTACCCG } \\
\text { AACTAAGGAGGATATTCATATG }\end{array}$ & $\begin{array}{l}1094 \text { (molde } \\
\text { pKD3) }\end{array}$ & $\begin{array}{c}1 \min 94^{\circ} \mathrm{C}, 1 \min 50^{\circ} \mathrm{C}, 1 \\
\min 72^{\circ} \mathrm{C}(30 \mathrm{x}) ; 8 \min 72 \\
{ }^{\circ} \mathrm{C}\end{array}$ & Culler 2015 \\
\hline pBAD & $\begin{array}{l}\text { F- ATGCCATAGCATTTTTATCC } \\
\text { R- GATTTAATCTGTATCAGG }\end{array}$ & 1007 & $\begin{array}{l}1 \min 94^{\circ} \mathrm{C}, 1 \min 55^{\circ} \mathrm{C}, 1 \\
\min 72^{\circ} \mathrm{C}(30 \mathrm{x}) ; 8 \min 72 \\
{ }^{\circ} \mathrm{C}\end{array}$ & Invitrogen \\
\hline $\begin{array}{l}\text { K1663 } \\
\text { K1664 }\end{array}$ & $\begin{array}{l}\text { F- GTCGCTCGAGAATGCAGGATACGGATTTTTTC } \\
\text { R- GTCGGAATTCTCAAATTAAGCCAGTAGCGG }\end{array}$ & $790^{\star}, 1207^{\star}$ & $\begin{array}{c}1 \min 94^{\circ} \mathrm{C}, 1 \min 56^{\circ} \mathrm{C}, 1 \\
\min 72^{\circ} \mathrm{C}(30 \mathrm{x}) ; 8 \min 72 \\
{ }^{\circ} \mathrm{C}\end{array}$ & $\begin{array}{l}\text { Sperandio } \\
\text { et al., } 1999\end{array}$ \\
\hline IuxSmut & $\begin{array}{l}\text { F- AGTTCATTTGAACTGGCTTTTTTCAATTAATTGTGAAGATA } \\
\text { GTTTACTGAGTGTAGGCTGGAGCTGCTTC } \\
\text { R- GGGAAGAAGAGTTCAGAAAATTTTAAAAAATTACC } \\
\text { GGAGGTGGCTAAATGGGAATTAGCCATGGTCC }\end{array}$ & $\begin{array}{l}1133 \text { (molde } \\
\text { pKD3) }\end{array}$ & $\begin{array}{c}1 \min 94^{\circ} \mathrm{C}, 1 \min 50^{\circ} \mathrm{C}, 1 \\
\min 72^{\circ} \mathrm{C}(30 \mathrm{x}) ; 8 \min 72 \\
{ }^{\circ} \mathrm{C}\end{array}$ & $\begin{array}{l}\text { Dados não } \\
\text { publicados }\end{array}$ \\
\hline
\end{tabular}

*O tamanho das sequências amplificadas com os iniciadores sdiA-DT podem ser de 840pb (gene sdiA nativo), de $1196 \mathrm{pb}$ (gene cat) ou de 1700pb (gene kan); as sequências amplificadas com os iniciadores qseC-DT podem ser de 2065 pb (gene qseC nativo) ou de 1141 pb (gene cat); as sequências geradas pela amplificação com os iniciadores K1663 e K1664 podem ser de 790 pb (gene luxS nativo) ou de 1207 pb (gene cat). 


\subsection{Curvas de crescimento}

Curvas de crescimento das amostras selvagens, mutantes e complementadas foram obtidas a fim de verificar se as mutações causaram alguma alteração no crescimento bacteriano que pudesse influenciar na leitura dos resultados dos testes fenotípicos realizados. As amostras foram cultivadas em caldo LB por $18 \mathrm{~h}$ a $37^{\circ} \mathrm{C}$ e, em seguida, diluídas $1: 100$ em caldo LB e incubadas a $37^{\circ} \mathrm{C}$, sob agitação de $250 \mathrm{rpm}$. A cada hora de crescimento foram realizadas medidas da $\mathrm{DO}_{600}$ até completar $8 \mathrm{~h}$.

\subsection{Ensaios de interação com células epiteliais in vitro}

\subsubsection{Adesão bacteriana em células epiteliais}

Os ensaios de adesão em células epiteliais HeLa foram realizados de acordo com Scaletsky e colaboradores (1984). As células foram cultivadas em garrafas de $25 \mathrm{ml}$ (Nunc) contendo $6 \mathrm{ml}$ de Meio Mínimo Essencial de Eagle, modificado por Dulbeco (DMEM; Cultilab) com antibiótico (penicilina $1000 \mathrm{U} / \mathrm{ml}$; estreptomicina 1 $\mathrm{mg} / \mathrm{ml}$ ), acrescido de $10 \%$ de soro fetal bovino (SFB; Cultilab), e mantidas por 2 a 3 dias a $37{ }^{\circ} \mathrm{C}$ sob atmosfera de $5 \%$ de $\mathrm{CO}_{2}$. Após o período de incubação, as células foram transferidas para placas de 24 poços contendo lamínulas de vidro, em uma concentração de $5 \times 10^{4}$ células/ml, e incubadas por $48 \mathrm{~h}$ sob as mesmas condições.

As amostras bacterianas foram inoculadas em $3 \mathrm{ml}$ de caldo de soja tripticase (TSB) e incubadas a $37^{\circ} \mathrm{C}$ por $18 \mathrm{~h}$. Uma alíquota de $40 \mu \mathrm{l}$ da cultura bacteriana foi adicionada a cada poço da placa contendo a cultura de células, previamente lavadas por 5 vezes com PBS (cloreto de sódio $137 \mathrm{mM}$; cloreto de potássio 2,7 mM; fosfato de sódio dibásico 8,1 mM; fosfato de potássio monobásico 1,5 mM; pH 7,4), e acrescidas de $960 \mu \mathrm{l}$ de meio DMEM estéril, sem antibiótico, contendo $2 \%$ de SFB e $1 \%$ de D-manose (diluição final de 1:25). O meio de cultura foi suplementado com os compostos 3o-C6-DL-HSL, MHF e epinefrina em determinados experimentos como descrito anteriormente (Item 4.2).

As placas foram incubadas por um período de $6 \mathrm{~h}$ a $37^{\circ} \mathrm{C}$, sendo que após as 3 primeiras horas de incubação a placa foi lavada por 4 vezes com PBS $1 \mathrm{X}$ e novamente adicionada de $1 \mathrm{~mL}$ de DMEM acrescido de $1 \%$ de D-manose. Após o 
período de $6 \mathrm{~h}$ as placas foram novamente lavadas por 5 vezes com PBS, a fim de remover as bactérias que não aderiram às células. Em seguida foram fixadas com metanol por $18 \mathrm{~h}$ a $4^{\circ} \mathrm{C}$. Após a fixação, as células foram coradas por 5 min com solução corante May-Grünwald 0,2 \% (diluído 1:2 em Tampão Sørensen diluído 1:2 em água destilada) e, em seguida, com Giemsa diluído 1:3 em Tampão Sørensen diluído 1:2 em água destilada, por 20 min. Após lavagem para retirada do excesso de corante, as lamínulas foram secas em temperatura ambiente e montadas em lâminas para microscopia com Entellan (Merck). As lâminas foram analisadas através de microscopia óptica, em aumento de $400 \mathrm{X}$.

\subsubsection{Quantificação de bactérias aderidas à células epiteliais}

Para determinar quantitativamente as bactérias aderidas às células, foi utilizada a mesma metodologia do sub-item supracitado, porém, as células foram incubadas diretamente no fundo dos poços das placas de 24 poços na ausência de lamínulas de vidro. Após o período de infecção foram realizadas 4 lavagens com PBS $1 \mathrm{X}$ e, em seguida, foi adicionada água estéril para realizar lise osmótica das células epiteliais. As suspensões foram coletadas e diluições apropriadas para contagem de UFC foram semeadas em placas de petri contendo LBA. A contagem de colônias foi realizada após incubação das placas de LBA por $18 \mathrm{~h}$ a $37^{\circ} \mathrm{C}$.

\subsubsection{Teste de FAS (Fluorescent actin staining)}

As amostras bacterianas foram submetidas a ensaios de polimerização da actina, seguindo protocolo descrito por Knutton e colaboradores (1989). O cultivo das células HeLa, bem como os ensaios de adesão a células epiteliais in vitro, foram realizados como descrito no item 4.6.1. Após o período de incubação e 4 lavagens com PBS $1 \mathrm{X}$, as células foram fixadas com p-Formaldeído $4 \%$ em PBS 1X, por 18 $\mathrm{h}$ a $4{ }^{\circ} \mathrm{C}$. As células foram novamente lavadas com PBS $1 \mathrm{X}$ e, em seguida, permeabilizadas pela adição de Triton X100 0,1\% em PBS 1 X por 4 min. Após novas lavagens, as células foram bloqueadas com solução de BSA 0,2 \% em PBS $1 \mathrm{X}$ por $30 \mathrm{~min}$ e, em seguida, foram adicionados $20 \mu \mathrm{L}$ de uma solução contendo 3 $U$ de Alexa Fluor 488 - Phalloidin (Molecular Probes) em BSA 0,2 \%. As placas foram incubadas por 45 min sob abrigo de luz e novamente lavadas com PBS 1X por 
três vezes de $5 \mathrm{~min}$. As lamínulas foram removidas da placa, secas com papel filtro e fixadas sobre lâminas de vidro com Mowiol (Calbiochem) adicionado de lodeto de Propídio (Molecular Probes) em uma concentração final de 1:1000. Após cerca de $20 \mathrm{~h}$ a $4{ }^{\circ} \mathrm{C}$, as lâminas foram observadas através de microscópio confocal de fluorescência em aumento de 630x (Microscópio LSM 510 Meta, Zeiss - Filtros: BP500-530IR - $488 \mathrm{~nm}$; LP560 - $543 \mathrm{~nm}$ ). O meio de cultura foi suplementado com os compostos 30-C6-DL-HSL, MHF e epinefrina em determinados experimentos como descrito anteriormente (Item 4.2).

\subsection{Biofilme}

\subsubsection{Ensaios de formação de biofilme - Cristal Violeta}

A análise quantitativa da formação de biofilme foi feita em placas de poliestireno de 96 poços seguindo a metodologia descrita por Christensen e colaboradores (1985) e Sheikh e colaboradores (2001), com modificações. Os préinóculos foram cultivados por $18 \mathrm{~h}$ a $37^{\circ} \mathrm{C}$, em caldo LB, em condições estáticas e, em seguida, diluídos 1:100 em placas de poliestireno de 96 poços (TPP, Suiça), em volume final de $200 \mu \mathrm{L}$. Após $24 \mathrm{~h}$ de incubação, as placas foram lavadas por $3 \mathrm{X}$ com PBS para remoção das bactérias planctônicas. O biofilme foi pré-fixado com $200 \mu \mathrm{L}$ de etanol a $75 \%$ por 10 min em temperatura ambiente. O fixador foi retirado e as bactérias coradas com $200 \mu \mathrm{L}$ de solução de cristal violeta a 0,5\% por 5 min. Após a remoção do corante e 4 lavagens com PBS, as placas foram secas à temperatura ambiente. O corante foi solubilizado com $200 \mu \mathrm{L}$ de etanol $95 \%$ durante 2 min a temperatura ambiente. Em seguida, foi realizada a leitura da absorbância a $595 \mathrm{~nm}$ no leitor de ELISA Multiskan ${ }^{\circledR} \mathrm{EX}$ (Thermo Isher Scientific, EUA). O meio de cultura foi suplementado com os compostos 30-C6-DL-HSL, MHF e epinefrina em determinados experimentos como descrito anteriormente (Item 4.2).

\subsubsection{Visualização da formação de biofilme através de microscópio confocal a laser}

Para verificar qualitativamente a formação de biofilme através de microscópio confocal, cada poço da placa de 24 poços foi preenchido com $300 \mu \mathrm{L}$ de agarose $3 \%$ 
esterilizada em autoclave. Após a solidificação, lamínulas de vidro foram inseridas verticalmente na agarose. Em seguida, foram adicionados aos poços $1 \mathrm{~mL}$ de cultura bacteriana diluída 1:100, e a placa foi incubada por 24 h a $37^{\circ} \mathrm{C}$ e/ou $26{ }^{\circ} \mathrm{C}$. Após o período de incubação e 4 lavagens com PBS $1 \mathrm{X}$, as bactérias aderidas à lamínula foram fixadas com $p$-Formaldeído $4 \%$ diluído em PBS $1 \mathrm{X}$, por $18 \mathrm{~h}$ a $4{ }^{\circ} \mathrm{C}$. Após 5 lavagens com PBS 1X, as lamínulas foram incubadas por 30 min com solução de bovine serum albumin (BSA) a 0,2\% em PBS 1X, a fim de bloquear marcações inespecíficas. Após 3 lavagens com PBS 1X, as lamínulas foram removidas das placas, secas com papel filtro e fixadas sobre lâminas de vidro com Mowiol (Calbiochem) adicionado de lodeto de Propídio (Molecular Probes) em uma concentração final de 1:1000. Após cerca de $20 \mathrm{~h}$ a $4{ }^{\circ} \mathrm{C}$, as lâminas foram observadas através de microscópio confocal de fluorescência em aumento de 630x (Microscópio LSM 510 Meta, Zeiss - Filtros: BP500-530IR - 488 nm; LP560 - 543 $\mathrm{nm})$. O meio de cultura foi suplementado com os compostos 30-C6-DL-HSL, MHF e epinefrina em determinados experimentos como descrito anteriormente (Item 4.2).

\subsubsection{Ensaio de produção de celulose e fímbria curli}

As amostras bacterianas foram cultivadas em placas de Ágar Vermelho Congo ( $2 \%$ agar, $1 \%$ ácido casamino; $0,15 \%$ extrato de levedura e $0,005 \%$ sulfato de magnésio), suplementadas com $40 \mu \mathrm{g} / \mathrm{ml}$ de Vermelho Congo e $20 \mu \mathrm{g} / \mathrm{ml}$ de Coomassie Brilliant Blue G250 (Merck, Alemanha), por períodos de 24 e 48 h a 26 ${ }^{\circ} \mathrm{C}$ e $37^{\circ} \mathrm{C}$, a fim de identificar a expressão da fímbria curli. $\mathrm{O}$ ensaio de celulose foi realizado com amostras bacterianas cultivadas em meio LB ágar sem sal suplementado com $100 \mu \mathrm{g} / \mathrm{ml}$ de Calcofluor (Sigma-Aldrich Co, EUA) por $24 \mathrm{~h}$ de incubação a $37^{\circ} \mathrm{C}$ e $26^{\circ} \mathrm{C}$. A produção de celulose foi identificada em luz UV com comprimento de onda de $366 \mathrm{~nm}$.

\subsection{Teste de motilidade em placa de ágar semi-sólido}

O teste de motilidade foi realizado de acordo com Sperandio e colaboradores (2002), com algumas alterações. As amostras em teste foram incubadas a $37^{\circ} \mathrm{C}$ por 18 h em 3 mL de meio LB. Uma alíquota do pré-cultivo foi introduzida no ágar semisólido $(0,3 \%)$ com auxílio de agulha bacteriológica, até atingir o fundo da placa de 
Petri. Após 8 horas de incubação a $26{ }^{\circ} \mathrm{C}$ e $37^{\circ} \mathrm{C}$, o halo formado pelo swimming bacteriano foi mensurado. O meio de cultura foi suplementado com os compostos 3o-C6-DL-HSL, MHF e epinefrina em determinados experimentos como descrito anteriormente (Item 4.2).

\subsection{Análise Transcricional}

\subsubsection{Extração de RNA}

Previamente à análise quantitativa da transcrição de genes de interesse, foi realizada a extração de RNA total das amostras de estudo. Brevemente, as amostras foram cultivadas inicialmente em $3 \mathrm{~mL}$ de $\mathrm{LB}$ a $37{ }^{\circ} \mathrm{C}$ por $16 \mathrm{~h}$. Em seguida, as culturas foram diluídas 1:100 em $30 \mathrm{~mL}$ de caldo LB e crescidas a 37ํㅡ $\mathrm{C}$ sob agitação constante de 150 rpm. O crescimento foi monitorado por leitura da absorbância a 600 nm através de espectrofotômetro (Biophotometer Plus, Eppendorf) até atingir a $\mathrm{DO}_{600} \mathrm{~nm}$ 0,5 ou 0,6. Após esse período o RNA foi extraído utilizando os kits RNAprotect ${ }^{\circledR}$ Bacteria Reagent e RNeasy ${ }^{\circledR}$ Mini Kit (QIAGEN, EUA), seguindo o protocolo do fabricante. Após a extração, foram adicionadas duas unidades DNAse A para cada micrograma de RNA (New England Biolabs, Reino Unido) para remover o DNA excessivo. A quantificação do RNA foi feita em NanoDrop (Biophotometer Plus, Eppendorf), por leitura da absorbância em comprimento de onda $260 \mathrm{~nm}$ e $280 \mathrm{~nm}$.

\subsubsection{PCR em Tempo Real}

O RNA extraído foi convertido a cDNA por transcriptase reversa (Applied Biosystems, EUA). Em seguida, o cDNA foi adicionado a uma reação contendo SYBR $^{\circledR}$ Green PCR Master Mix (Applied Biosystems, EUA) e iniciadores específicos para cada gene estudado. Os iniciadores utilizados foram previamente validados e otimizados para eficiência de amplificação e especificidade e suas sequências estão descritas na tabela 3. Os dados foram normalizados com os níveis de transcrição de rpoA e analisados utilizando um comparativo crítico threshold $(C t)$. Os níveis transcricionais dos genes estudados nas amostras mutantes foram quantificados 
pelo método de quantificação relativa e expressos como diferenças comparadas com os níveis da amostra selvagem. Os experimentos foram realizados em triplicata e os dados foram coletados e analisados utilizando o software 7500 Fast Real-Time PCR v2.0.5 (Applied Biosystems, EUA). Barras de erros representam os desvios padrões dos valores de $C t$ (ou $\Delta \Delta C t$ ) nas triplicatas analisadas.

\subsection{Análises estatísticas}

As análises estatísticas foram realizadas utilizando o teste de comparação de médias entre grupos - One-Way ANOVA (GraphPad Prism 6.0). A análise Post Hoc foi realizada com os métodos Tukey ou Dunnett, de acordo com o ensaio realizado. Valores de $P<0.05$ foram considerados estatisticamente significativos.

Tabela 3: Iniciadores utilizados nas reações de qRT-PCR

\begin{tabular}{|c|c|c|}
\hline Iniciadores & Sequência $\left(5^{\prime}-3^{\prime}\right)$ & Referência \\
\hline rpoA-RT & $\begin{array}{c}\text { F - GCGCTCATCTTCTTCCGAAT } \\
\text { R - CGCGGTCGTGGTTATGTG }\end{array}$ & $\begin{array}{l}\text { WALTERS, SPERANDIO, } \\
2006\end{array}$ \\
\hline fimA-RT & $\begin{array}{l}\text { F - TGTCCCTCAGTTCTACAGCG } \\
\text { R - TCCTAACTGAACGGTTTGATC }\end{array}$ & $\begin{array}{l}\text { SHARMA, BEARSON, } \\
\text { BEARSON, } 2010\end{array}$ \\
\hline csgD-RT & $\begin{array}{l}\text { F - GGTAACTATCGTTATAACAGCA } \\
\text { R - TGCCCAGGAAACCGCTTG }\end{array}$ & CULLER, 2015 \\
\hline $\operatorname{csgA-RT}$ & $\begin{array}{l}\text { F - GATGTTGGTCAGGGCTCAG } \\
\text { R - CCACCGAATTGTTTAACTGTC }\end{array}$ & $\begin{array}{l}\text { SHARMA, BEARSON E } \\
\text { BEARSON, } 2010\end{array}$ \\
\hline bcsA-RT & $\begin{array}{c}\text { F - AGCTCGGCTTCCGTGGC } \\
\text { R - TCATTGTTGAGCCAAAGCCT }\end{array}$ & CULLER, 2015 \\
\hline flic-RT & $\begin{array}{l}\text { F - GGGCTGAATGGCTTCTCAG } \\
\text { R - TCGTCAACACCGTTCGCATA }\end{array}$ & Este estudo \\
\hline eae-RT & $\begin{array}{c}\text { F - GCTGGCCTTGGTTTGATCA } \\
\text { R - GCGGAGATGACTTCAGCACTT }\end{array}$ & KENDALL et al., 2007 \\
\hline ler-RT & $\begin{array}{l}\text { F - CGACCAGGTCTGCCCTTCT } \\
\text { R- GCGCGGAACTCATCGAAA }\end{array}$ & $\begin{array}{l}\text { WALTERS, SPERANDIO, } \\
2006\end{array}$ \\
\hline espA-RT & $\begin{array}{c}\text { F - TGAGAATCGCAGCCTGAAAA } \\
\text { R - CGAAGGATGAGGTGGTTAAGCT }\end{array}$ & $\begin{array}{l}\text { WALTERS, SPERANDIO, } \\
2006\end{array}$ \\
\hline luxS-RT & $\begin{array}{l}\text { F - CTGCAACGAGTCCATCTG } \\
\text { R - GCGTGCCGAACAAAGAAG }\end{array}$ & Dados não publicados \\
\hline qseC-RT & $\begin{array}{c}\text { F - AATGGGAATACCGTGAAGACATG } \\
\text { R - CCAACCACGGGATCAATTG }\end{array}$ & $\begin{array}{l}\text { NJOROGUE, } \\
\text { SPERANDIO, } 2012\end{array}$ \\
\hline sdiA-RT & $\begin{array}{l}\text { F - GCAATTGATCCGGTGCTGAA } \\
\text { R - TCATTCCACATTAAATGGCCC }\end{array}$ & Dados não publicados \\
\hline
\end{tabular}




\section{RESULTADOS}

\subsection{Obtenção dos mutantes nos genes qseC, sdiA, duplo ( $\Delta q s e C / \Delta / u x S)$ e triplo ( $\Delta q s e C / \Delta / u x S / \Delta s d i A)$}

Antes de iniciar os ensaios para construção de mutantes a presença dos genes qseC e sdiA na amostra AP155, envolvidos no sistema de Quorum Sensing, foi verificada através de PCR e análise da sequência de nucleotideos. O tamanho dos fragmentos gerados foram de $2065 \mathrm{pb}$ para o gene qse $C$ e $840 \mathrm{pb}$ para sdiA. O produto destas reações foi enviado para sequenciamento no Centro de Estudos do Genoma Humano - USP, e as sequências foram analisadas através da ferramenta BLAST - NCBI. A identidade nucleotídica de cada fragmento demonstrou identidade de $99 \%$ com as sequências depositadas no banco de seqüências GenBank (disponível em http://www.ncbi.nlm.nih.gov/genbank/) confirmando a presença dos genes no genoma da amostra de aEPEC AP155 (dados não mostrados).

Para promover a deleção dos genes de interesse foi selecionada a metodologia baseada na recombinação homóloga mediada pelo sistema Lambda Red (DATSENKO, WANNER, 2000). Os plasmídeos auxiliares pKD3, pKD4, pKD46 e pCP20 foram extraídos e purificados como demonstrado em corrida eletroforética em gel de agarose na figura 1. Cassetes de recombinação foram amplificados a partir dos plasmídeos pkD3 e pkD4 (Figura 2) e, em seguida, foram transformados na amostra AP155 selvagem previamente transformado com o plasmídeo pKD46. As células transformadas foram plaqueadas em meio LBA com adição do antibiótico cloranfenicol ou canamicina, e colônias resistentes foram selecionadas. As mutações foram confirmadas por PCR utilizando iniciadores (Tabela 2) que flanqueiam regiões externas ao gene alvo da recombinação por homologia, detectando a substituição do gene selvagem pelo cassete de resistência. Os dois genes, qseC e sdiA, foram substituídos com sucesso pelo gene de resistência ao cloranfenicol (cat) na amostras selvagem de AP155, gerando as amostras AP155 $\Delta q s e C$ e AP155 $\Delta$ sdiA (Figura 3B-C). Também foi confirmada a deleção do gene luxS na amostra AP155 $\Delta$ luxS cedida pela Dra. Vanessa Bueris (Figura 3A). 
O próximo passo foi fazer uma mutação dupla nos genes qseC e luxS. Com este intuito, a amostra AP155 $\Delta q s e C$ foi transformada com o plasmídeo pCP20, que expressa enzimas que realizam a remoção do gene cat integrado ao cromossomo na região do gene qseC. A remoção do cassete foi confirmada por PCR utilizando o par de iniciadores DT indicado pela presença de uma "cicatriz" do tamanho de 254 pb (Figura 4A). Após a "cura" do plasmídeo pCP20, o plasmídeo pKD46 foi novamente transformado na amostra AP155 $\Delta q s e C$, e esta foi submetida a um novo evento de recombinação homóloga, desta vez tendo como alvo o gene luxS. Colônias resistentes ao antibiótico cloranfenicol foram selecionadas e o gene cat que substituiu o gene luxS pôde ser visualizado por PCR, confirmando a obtenção da amostra AP155 $\Delta q s e C / \Delta l u x S$ (Figura 4A). Em seguida, a amostra AP155 $\Delta q s e C / \Delta l u x S$ foi transformada novamente com o plasmídeo pKD46 e o gene sdiA localizado no cromossomo da bactéria foi substituído pelo cassete de resistência ao antibiótico canamicina (Figura 4B). Desta maneira, a amostra AP155 $\Delta q s e C / \Delta l u x S / \Delta s d i A$ foi obtida. Para certificar que as mutações foram bemsucedidas, os fragmentos amplificados com os iniciadores DT foram purificados e enviados para sequenciamento. As sequências de bases demonstraram identidade entre 95\% a 99\% de similaridade com sequências dos plasmídeos pKD3 e pKD4 depositadas no banco de sequências GenBank (dados não mostrados).

\subsection{Complementação das amostras mutantes}

A complementação das amostras mutantes foi feita pela transformação com um plasmideo de alta expressão contendo uma cópia selvagem do gene deletado, com o objetivo de restaurar a condição selvagem da amostra e relacionar possíveis mudanças fenotípicas à falta do gene na amostra mutante. A amostra AP155 $\Delta s d i A$ foi complementada com o plasmideo pHFC01 (Tabela 1) e a amostra AP155 $\Delta$ qseC foi complementada com o plasmideo pVS155, contendo uma cópia dos genes selvagens sdiA e qseC, respectivamente. A confirmação da complementação foi feita por PCR utilizando iniciadores pBAD-F e pBAD-R (Tabela 1), que flanqueiam o sítio múltiplo de clonagem do plasmideo pBAD/ Myc-His A, amplificando o inserto clonado. 

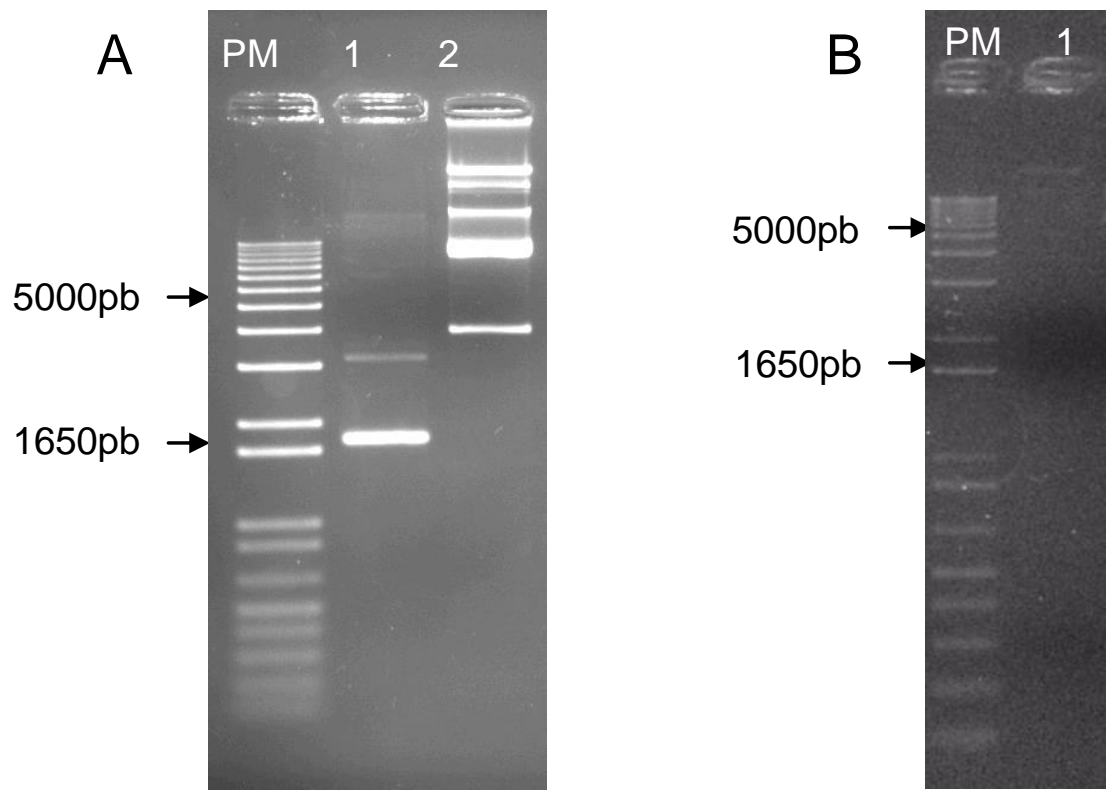

Figura 1 - Extração dos plasmídeos acessórios do sistema Lambda Red. Após corrida eletroforética, o DNA plasmidial foi corado com brometo de etídio $(10 \mu \mathrm{g} / \mathrm{ml})$. (A) PM - $1 \mathrm{~Kb}$ DNA ladder plus; 1 - pkD3; 2 - pkD46; (B) PM - 1Kb DNA ladder plus; 1 - pCP20.

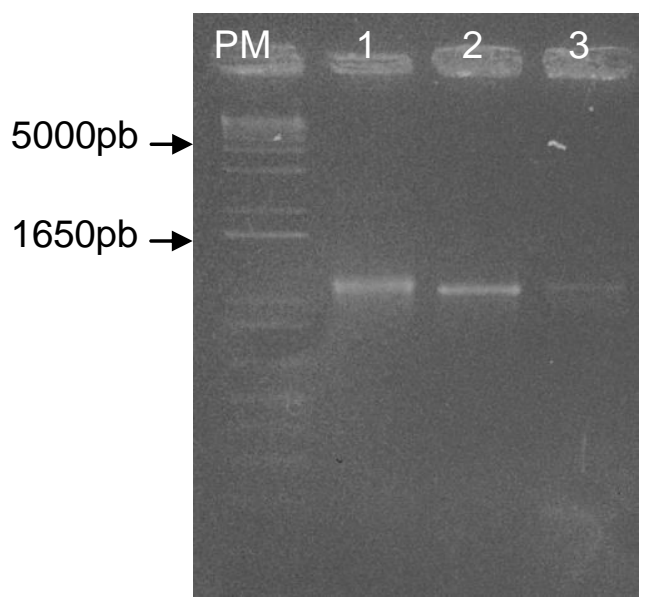

Figura 2 - Amplificação do cassete de recombinação cat, com extremidades homólogas à (1) luxS, (2) sdiA e (3) qseC. Eletroforese em gel de agarose $1 \%$ do produto amplificado de 1133 pb, 1094 pb e 1094 pb, respectivamente, após coloração com brometo de etídio (10 $\mu \mathrm{g} / \mathrm{ml})$. PM- $1 \mathrm{~Kb}$ Plus DNA Ladder (Invitrogen). 

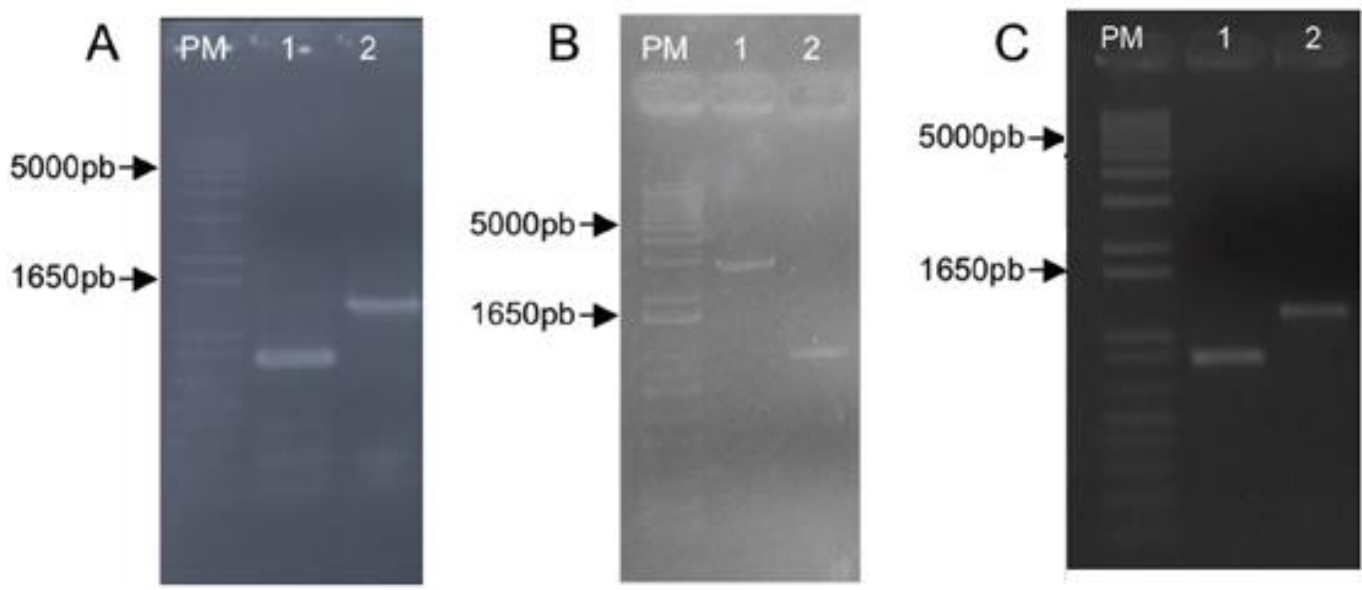

Figura 3 - Detecção da deleção dos genes (A) luxS, (B) qseC e (C) sdiA. Eletroforese em gel de agarose $1 \%$ dos produtos amplificados referentes às amostras selvagens e mutantes, após coloração com brometo de etídio $(10 \mu \mathrm{g} / \mathrm{ml})$. (A) PM - 1Kb DNA ladder plus; 1 - AP155 WT (luxS) 790 pb; 2 - AP155 $\Delta$ luxS (cat) 1207 pb; (B) PM - 1Kb DNA ladder plus; 1 AP155 WT (qseC) 2065 pb; 2 - AP155 $\Delta$ qseC (cat) 1141 pb, (C) PM - 1Kb DNA ladder plus; 1 - AP155 WT (sdiA) 840 pb; 2 - AP155 $\Delta$ sdiA (cat) 1196 pb.

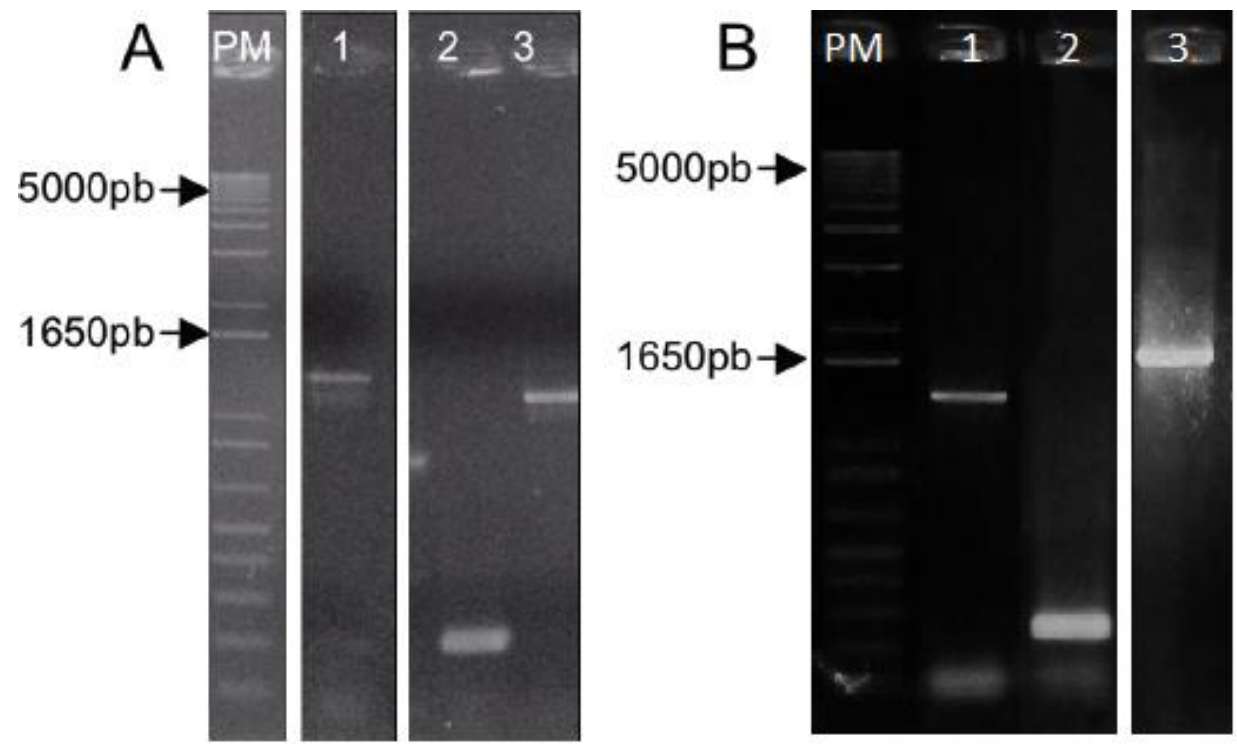

Figura 4 - Detecção da deleção do duplo mutante em luxS e qseC e triplo mutante em luxS, qseC e sdiA. Eletroforese em gel de agarose $1 \%$ dos produtos amplificados referentes às amostras selvagem e mutante, após coloração com brometo de etídio $(10 \mu \mathrm{g} / \mathrm{ml})$. (A) PM $1 \mathrm{~Kb}$ DNA ladder plus; 1 - AP155 $\Delta q s e C$; 2 - "cicatriz" da remoção de cat; 3 - AP155 $\Delta q s e C / \Delta / u x S$ (cat). (B) PM - 1Kb DNA ladder plus; 1 - AP155 $\Delta q s e C / \Delta / u x S ; 2$ - "cicatriz" da remoção de cat; 3 - AP155 $\Delta q s e C / \Delta / u x S / \Delta$ sdiA (kan). 


\subsection{Curvas de crescimento das amostras selvagens, mutantes e complementadas}

A fim de verificar se as amostras mutantes e complementadas tiveram suas taxas de crescimento comprometidas, curvas de crescimento foram avaliadas antes de realizar testes fenotípicos, que poderiam ser influenciados de acordo com o crescimento celular da amostra. Na figura 5 é possível observar que não houve diferença significativa no crescimento entre amostras selvagens, mutantes e complementadas, indicando que as mutações e complementações não afetaram de forma expressiva o crescimento bacteriano das amostras estudadas.

\subsection{Ensaio de motilidade em ágar semi-sólido}

A motilidade das amostras selvagem, mutantes e complementadas foi verificada segundo a metodologia descrita por Sperandio, Torres e Kaper (2002). O halo formado no ágar semi-sólido $(0,3 \%)$ corresponde à migração da amostra promovida pela movimentação flagelar. Quando incubadas a $26{ }^{\circ} \mathrm{C}$ (Figura $6 \mathrm{~A}$ ) foi possível verificar uma diminuição significativa na motilidade das amostras mutantes em luxS, qseC, sdiA e pela amostra $\Delta / u x S / \Delta q s e C$ quando comparadas à amostra selvagem. A amostra $\triangle l u x S$ apresentou o menor halo entre as mutantes, enquanto 0 duplo mutante demonstrou um resultado similar à amostra mutante em luxS. O triplo mutante não resultou em redução significativa da motilidade. Quando incubada a 37 ${ }^{\circ} \mathrm{C}$ (Figura 6B), a amostra mutante em qseC obteve resultados opostos quando comparada ao crescimento realizado a $26^{\circ} \mathrm{C}$, apresentando halos maiores do que a amostra selvagem. AP155 $\Delta / u x S$ se comportou de maneira similar ao crescimento à $26 \stackrel{\circ}{\circ}$, sofrendo uma grande redução na motilidade. Sob temperatura de $37 \stackrel{\circ}{ } \mathrm{C}$, as amostras $\Delta s d i A$, duplo e triplo mutante não apresentaram diferenças significativas quando comparadas à amostra selvagem.

A adição de autoindutores ao meio semi-sólido aumentou a motilidade da maioria das amostras (Figura 7A-B). Al-2 exógeno foi capaz de aumentar a 

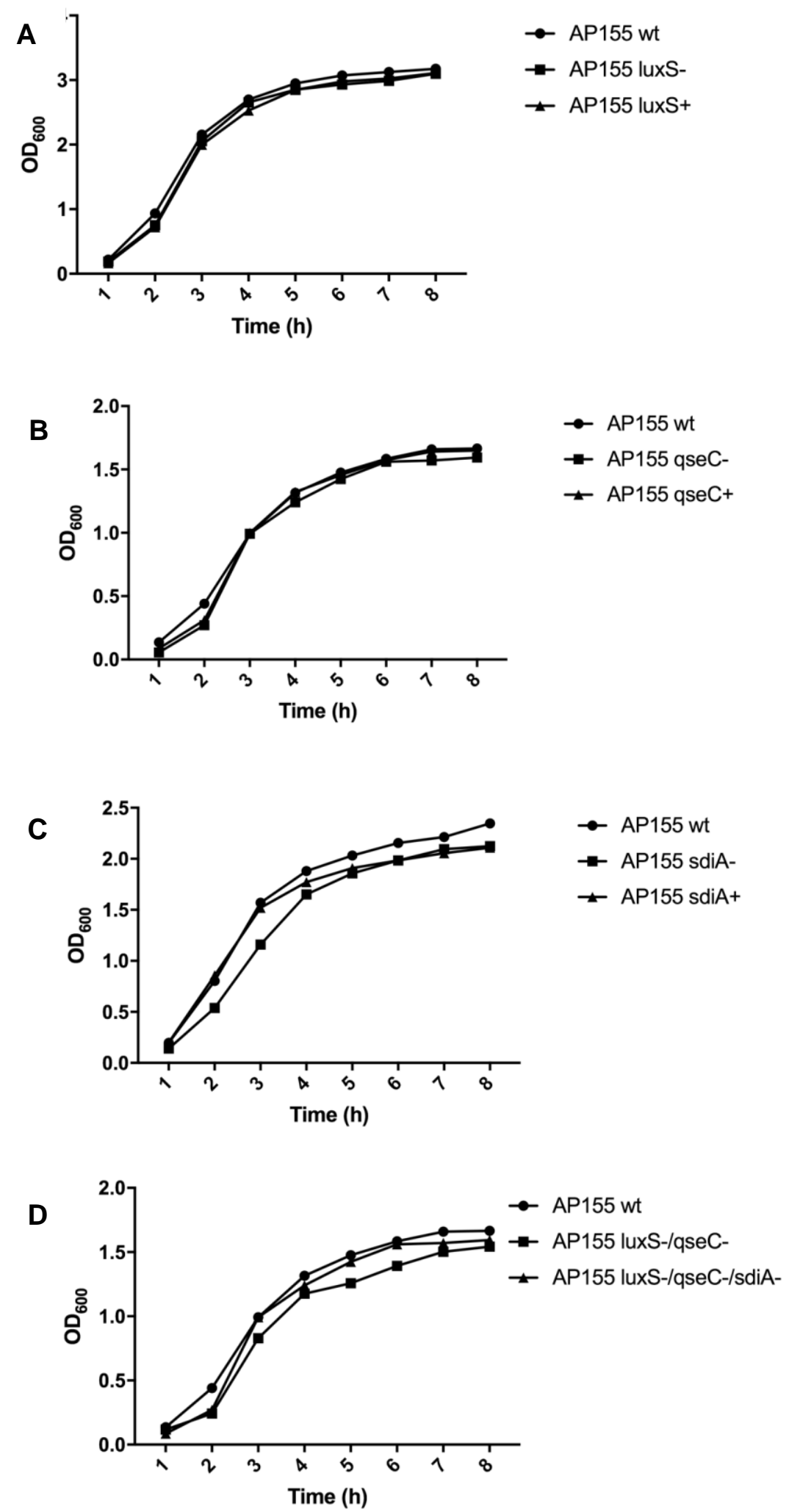

Figura 5 - Curva de crescimento em meio LB das amostras AP155 selvagem e mutantes. (A) AP155 WT, AP155 $\Delta / u x S$, AP155 $\Delta / u x S^{+}$; (B) AP155 WT, AP155 $\Delta q s e C$, Ap155 $\Delta q s e C^{+}$; (C) AP155 WT, AP155 $\Delta$ sdiA, AP155 $\Delta s d i A^{+}$; (D) AP155 WT, AP155 $\Delta q s e C / \Delta / u x S$, AP155 $\Delta q s e C / \Delta / u x S / \Delta s d i A$. 
A

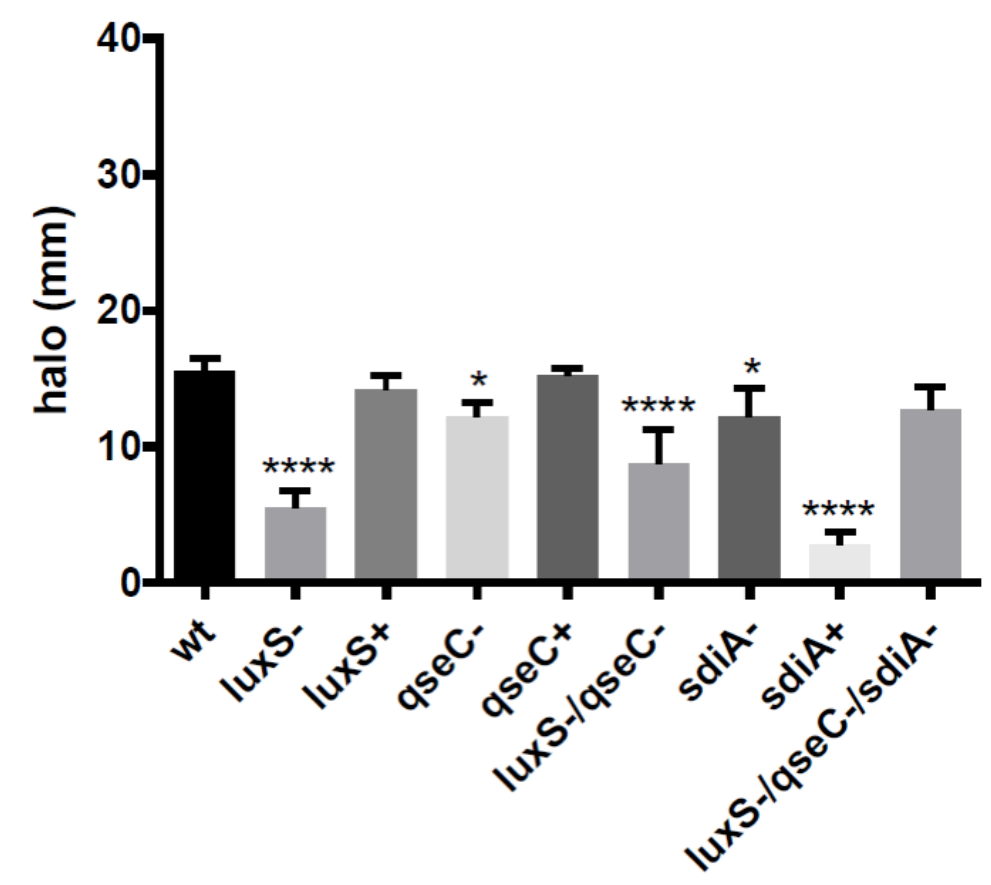

B

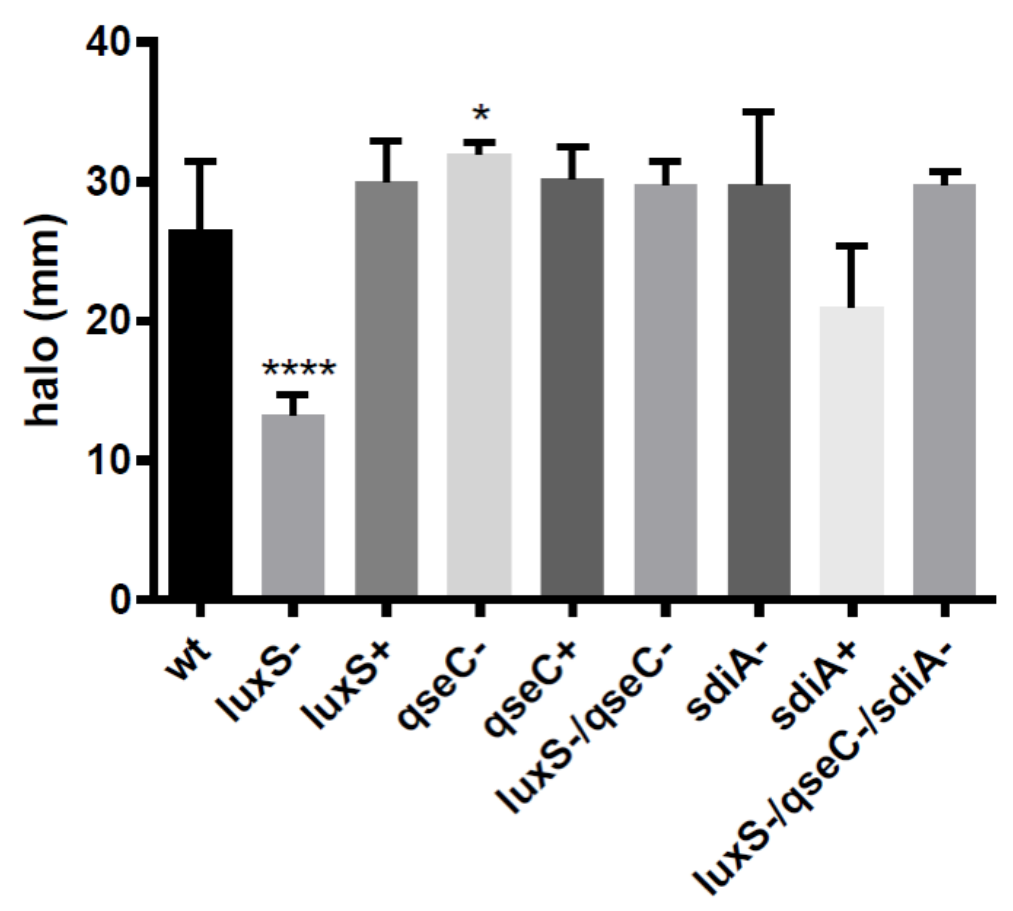

Figura 6 - Ensaio de motilidade em ágar semi-sólido (0,3\%) das amostras AP155 selvagem e mutantes, após incubação por $8 \mathrm{~h}$ a $(\mathbf{A}) 26^{\circ} \mathrm{C}$ e (B) $37^{\circ} \mathrm{C}$. Os valores correspondem à média de três triplicatas, mais ou menos o desvio padrão ( $\left.{ }^{*} p<0,05 ;{ }^{* * *} p<0,0001\right)$. 

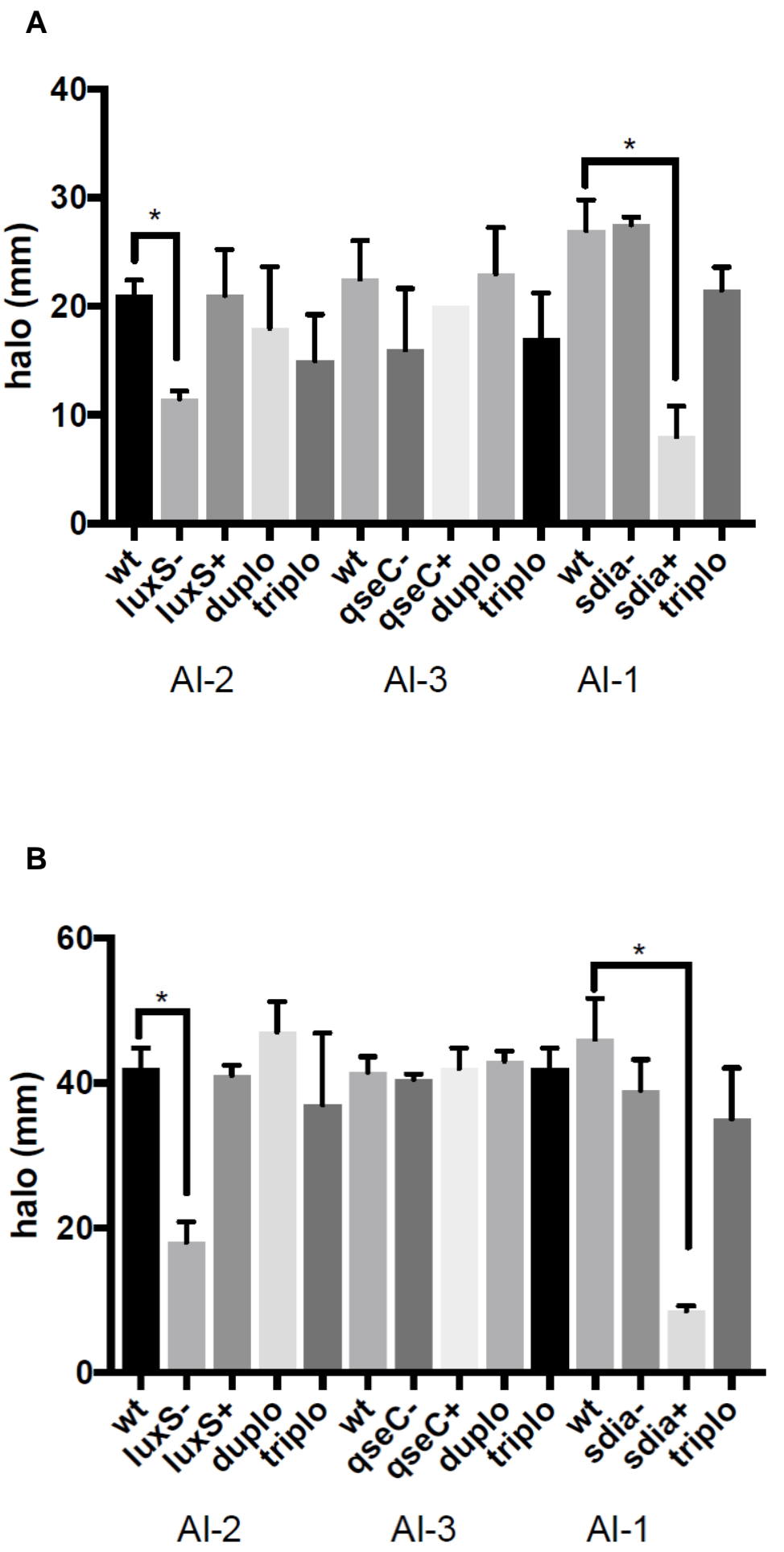

Figura 7 - Ensaio de motilidade em ágar semi-sólido (0,3\%) das amostras AP155 selvagem e mutantes, após incubação por $8 \mathrm{~h}$ a (A) $26^{\circ} \mathrm{C}$ e (B) $37^{\circ} \mathrm{C}$, na presença de moléculas autoindutoras. Os valores correspondem à média de três triplicatas, mais ou menos o desvio padrão $\left({ }^{*} p<0,05\right)$. 
motilidade de todas as amostras testadas, com exceção da amostra triplo mutante, que se comportou de maneira similar ao experimento sem adição de Al-2. A presença de $\mathrm{Al}-2$ exógeno resultou em dados similares entre a amostra mutante em luxS e amostra selvagem na ausência de Al-2 exógeno. Assim como a amostra AP155 $\Delta l u x S$, na presença de Al-2 exógeno as amostras mutante duplo e triplo demonstraram níveis de motilidade semelhantes à amostra selvagem na ausência de Al-2 no meio. A adição de epinefrina aumentou a motilidade das amostras selvagem, mutante em qseC, duplo e triplo mutantes. As amostras AP155 $\Delta s d i A$ e triplo mutante não sofreram alterações significativas na motilidade com a adição de Al-1 exógeno em comparação à amostra selvagem. A amostra complementada demonstrou menor motilidade em comparação às amostras selvagens e mutantes.

\subsection{Expressão de fímbria curli}

A fímbria curli foi descrita como uma importante estrutura do EPS, com funções na formação de biofilme e adesão a superfícies por E. coli, e sua expressão pode ser avaliada fenotipicamente pela capacidade desta estrutura se ligar ao corante Vermelho Congo (HAMMAR et al., 1995; ÓLSEN et al., 2002). Neste ensaio, colônias avermelhadas indicam expressão de fímbria curli, enquanto colônias brancas indicam a ausência falta de sua expressão.

Após 24 horas de crescimento a $26^{\circ} \mathrm{C}$, (Figura 8A-C) a amostra selvagem demonstrou coloração avermelhada, assim como as amostras mutante em luxS e mutante em sdiA, indicando expressão de fímbria curli. A coloração branca das amostras mutante em qseC e mutantes duplo e triplo indicam ausência de expressão de fímbria curli. Após 48 horas de crescimento (dados não mostrados) a maioria das colônias apresentou coloração mais avermelhada, mesmo as amostras carentes em expressão de curli. A única exceção foi a amostra AP155 $\Delta$ sdiA complementada, quel após 24 e 48 horas permaneceu com coloração branca.

Quando incubadas a $37^{\circ} \mathrm{C}$, após 24 horas de crescimento, (Figura 8B-D), as colônias apresentaram coloração similar à observada a $26{ }^{\circ} \mathrm{C}$, porém, levemente menos avermelhadas. As amostras incapazes de expressar curli a $26 \stackrel{\circ}{\circ}$ 
continuaram apresentando o mesmo fenótipo a $37^{\circ} \mathrm{C}$. Após 48 horas, as colônias não apresentaram diferenças notáveis na coloração, apesar da amostra mutante em qseC ter demonstrado uma coloração mais avermelhada.

\subsection{Produção de celulose}

Amostras produtoras de celulose como componente do EPS foram identificadas pela adição de calcofluor em ágar, que detecta as ligações glicosídicas $\beta-1,4$ de moléculas de celulose e permite a visualização desta estrutura sob fluorescência a 366nm (ZOGAJ et al., 2001). Após $24 \mathrm{~h}$ de incubação a $26{ }^{\circ} \mathrm{C}$ (Figura 9A) foi observada produção de celulose apenas pela amostra selvagem, evidenciada pela luminosidade emitida pelas colônias quando expostas à luz UV. As colônias incubadas a $37{ }^{\circ} \mathrm{C}$ (Figura 9B) foram todas positivas para produção de celulose.

\subsection{Formação de biofilme em superfície abiótica}

\subsubsection{Coloração por Cristal Violeta}

A formação de biofilme em placas de poliestireno foi avaliada no período de 24 horas sob temperatura de $26^{\circ} \mathrm{C}$ e/ou $37^{\circ} \mathrm{C}$. Na figura $10 \mathrm{~B}$ pode-se observar que a $37^{\circ} \mathrm{C}$ as amostras $\Delta / u x S, \Delta q s e C$ e triplo mutante aumentaram significativamente a produção de biofilme em relação a amostra selvagem. A amostra duplo mutante não demonstrou diferença significativa, gerando resultados mais próximos aos obtidos pela amostra mutante em qseC do que pela amostra mutante em luxS. A amostra mutante em sdiA foi praticamente incapaz de formar esta estrutura. Interessantemente, a amostra triplo mutante apresentou a maior formação de biofilme entre todas as amostras, com resultados mais próximos ao mutante em luxS do que os obtidos pelas amostras $\Delta q s e C$ e $\Delta s d i A$. 
A
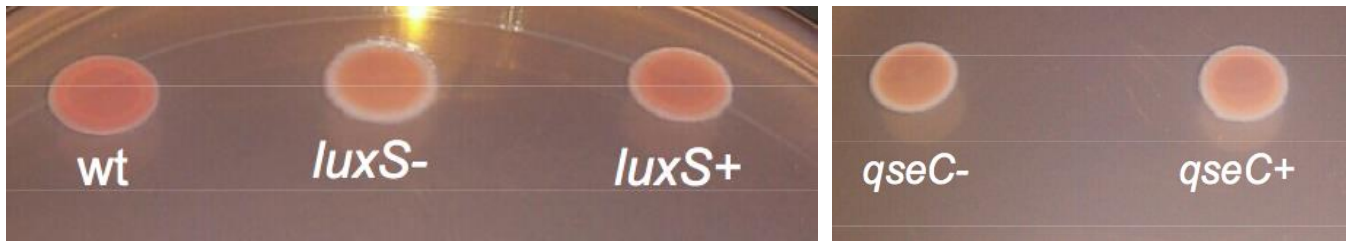

B
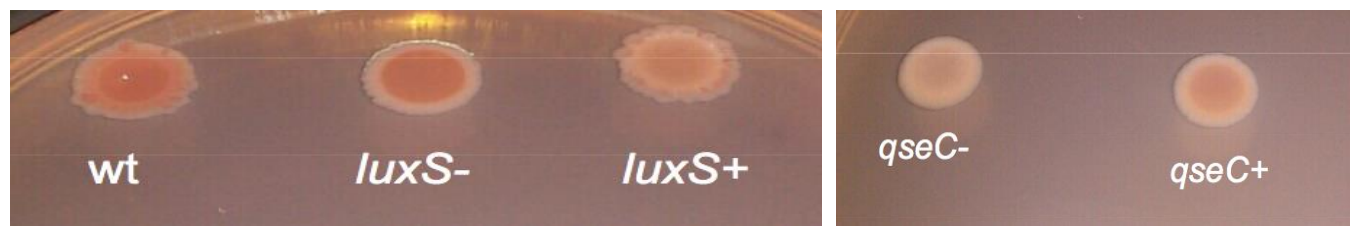

C
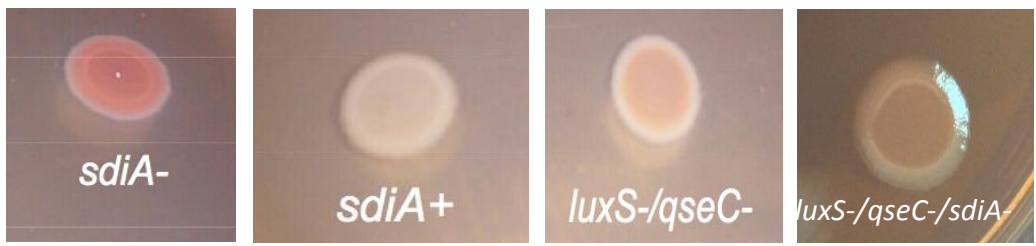

D
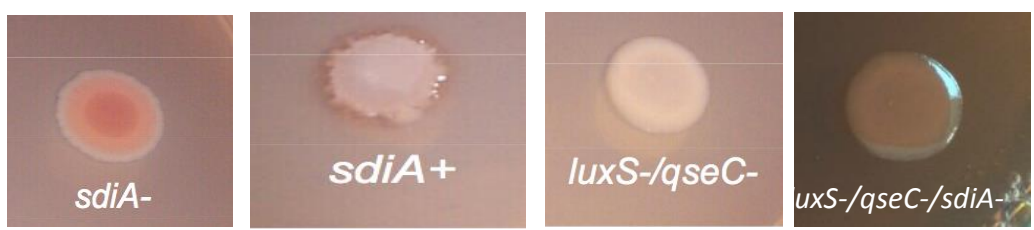

Figura 8 - Produção de fimbria curli em placas de Vermelho Congo das amostras AP155 selvagem e mutantes, após incubação por $24 \mathrm{~h}$ a $(\mathbf{A}, \mathbf{C}) 26^{\circ} \mathrm{C}$ e (B, D) $37^{\circ} \mathrm{C}$.

A

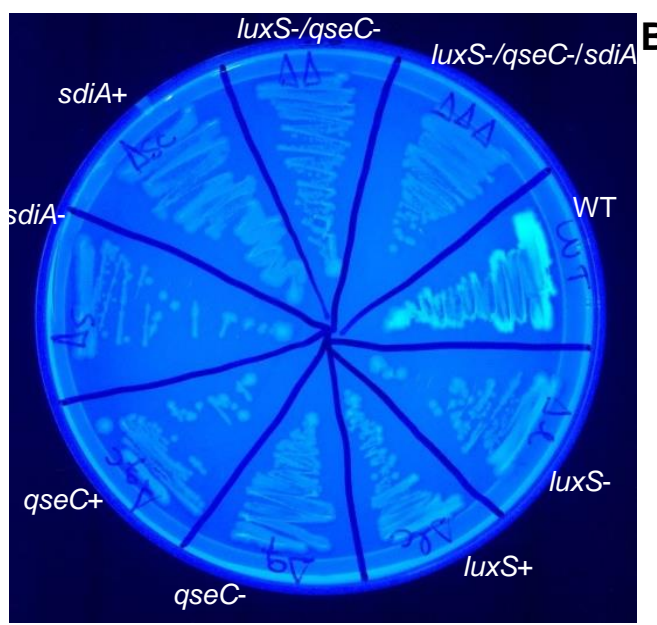

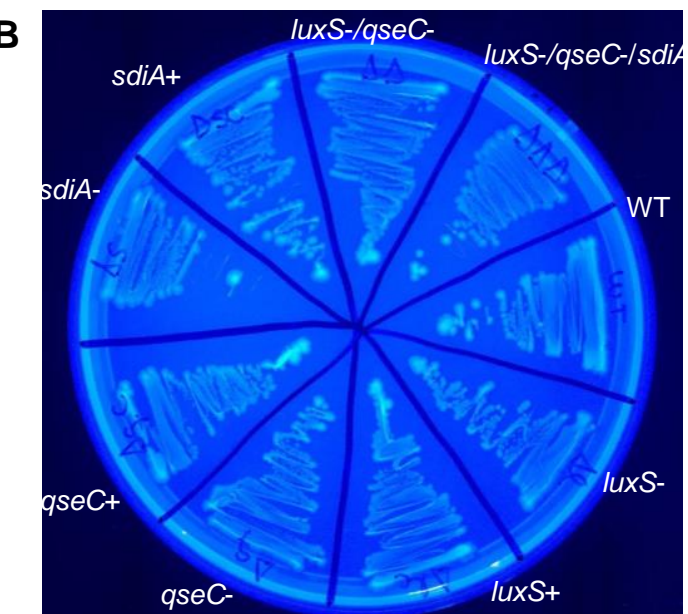

qseC

Figura 9 - Produção de celulose das amostras AP155 selvagem e mutantes, em placas contendo Calcofluor, após $24 \mathrm{~h}$ de incubação a $26^{\circ} \mathrm{C}$ (A) e $37^{\circ} \mathrm{C}$ (B). 
Todas as amostras que foram capazes de produzir biofilme a $37^{\circ} \mathrm{C}$ apresentaram maior produção desta estrutura a $26{ }^{\circ} \mathrm{C}$ (Figura 10A). A amostra mutante em qseC apresentou redução na formação de biofilme, se opondo ao resultado obtido a $37^{\circ} \mathrm{C}$. Já as amostras mutante em luxS e triplo mutante continuaram a apresentar as maiores formações de biofilme nesta temperatura e a amostra duplo mutante não foi capaz de formar biofilme. A amostra mutante em sdiA se comportou de maneira similar ao crescimento a $37^{\circ} \mathrm{C}$, apresentando um ligeiro aumento de biofilme porém significativamente menor do que o resultado obtido pela amostra selvagem. A amostra triplo mutante novamente se comportou de maneira similar a amostra mutante em luxS nesta temperatura.

Os efeitos da adição de Al-1 no meio de cultura (Figura 11) resultaram em diminuição da formação de biofilme pelas amostras selvagem e $\Delta s d i A^{+}$, com uma redução mais pronunciada sob temperatura de $26 \stackrel{\circ}{\circ}$. A presença de Al-2 exógeno no meio de cultura diminuiu a formação desta estrutura em ambas as temperaturas testadas. A amostra mutante em luxS obteve resultados parecidos à amostra selvagem, demonstrando que o Al-2 adicionado realizou uma possível restauração dos efeitos da deleção de luxS. A amostra triplo mutante apresentou formação de biofilme significativamente maior que a amostra selvagem. Foi possível observar ligeira redução da formação de biofilme em todas as amostras após a adição de epinefrina ao meio de cultura.

\subsubsection{Análise por microscopia confocal a laser}

A visualização da estrutura do biofilme através de microscopia confocal a laser permite que seja feita uma avaliação qualitativa da biomassa aderida à superfície da lamínula de vidro. Desta maneira, é possível verificar a arquitetura do biofilme formado e realizar uma análise comparativa entre a amostra selvagem e amostras mutantes. Os resultados estão apresentados nas figuras 12 a 17.

A amostra mutante em luxS apresentou uma camada de biofilme ligeiramente mais espessa do que a amostra selvagem sob temperatura de $26{ }^{\circ} \mathrm{C}$.A amostra mutante em qseC formou pouco biofilme, com bactérias esparsamente 
A

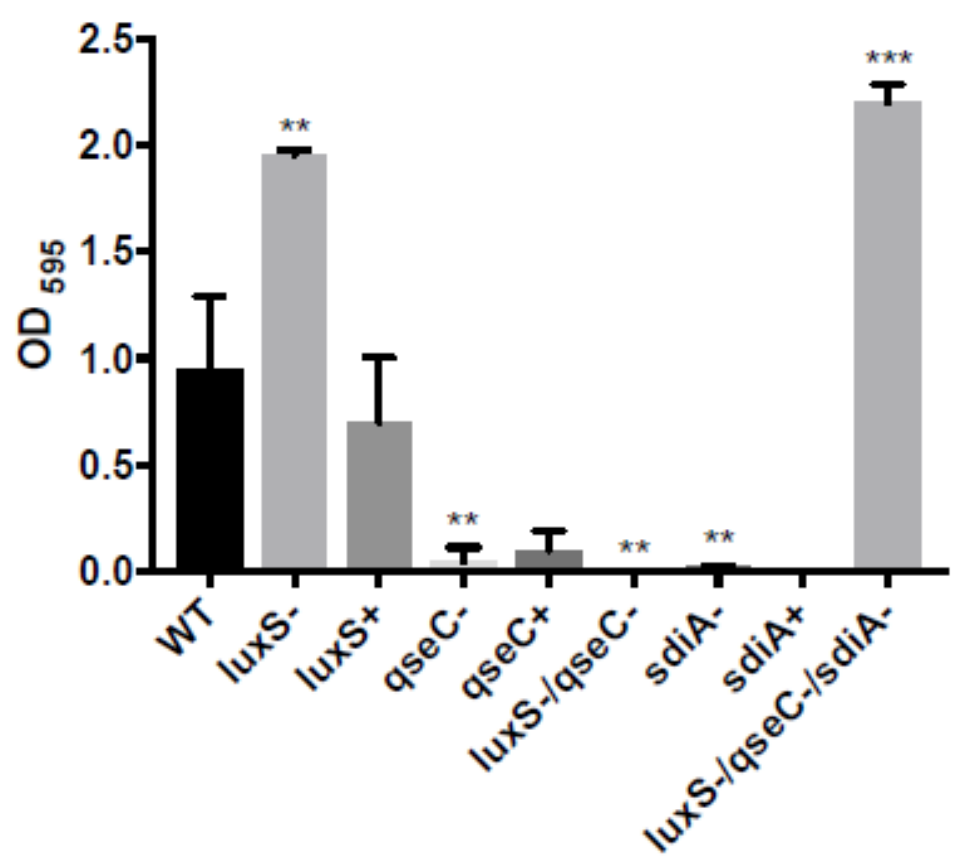

B

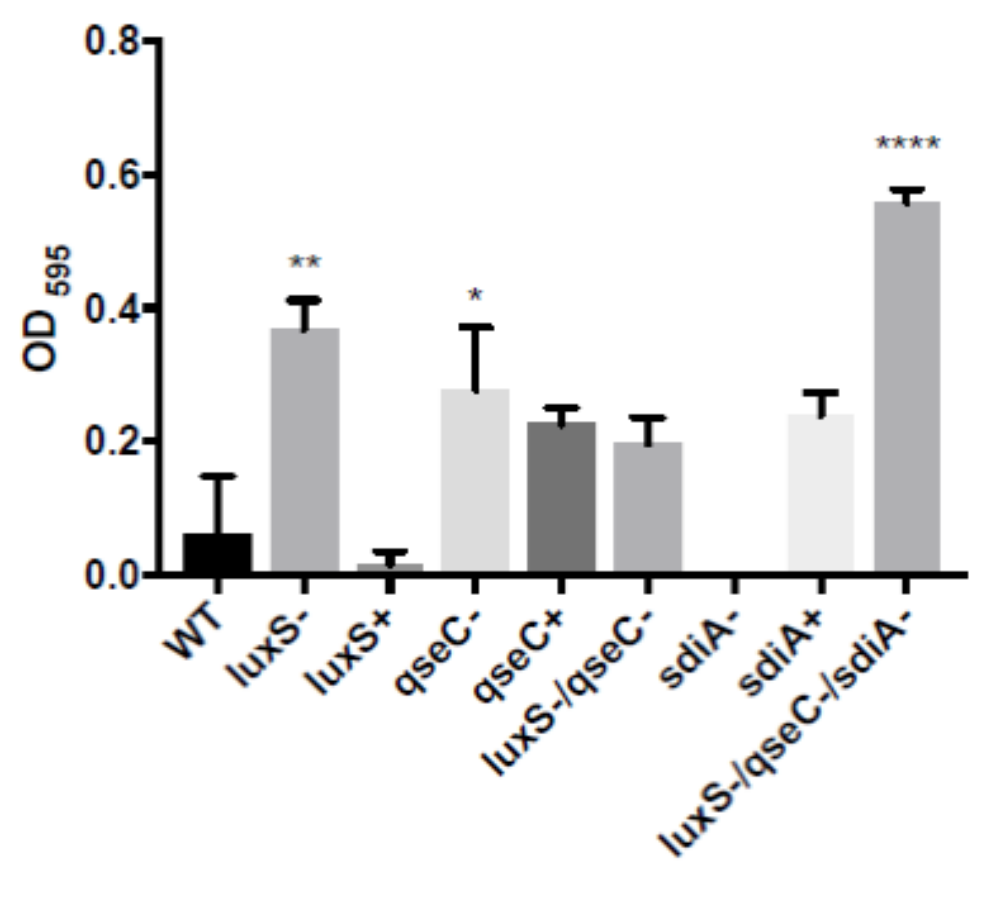

Figura 10 - Formação de biofilme em placas de poliestireno pelas amostras AP155 selvagem e mutantes, após $24 \mathrm{~h}$ de incubação em LB a $26{ }^{\circ} \mathrm{C}(\mathbf{A})$ e $37^{\circ} \mathrm{C}$ (B). Os valores correspondem à média de três triplicatas, mais ou menos o desvio padrão $\left({ }^{*} p<0,05\right.$; $\left.{ }^{* *} p<0,01 ;{ }^{* * *} p<0,001 ;{ }^{* * \star *} p<0,0001\right)$. 
A

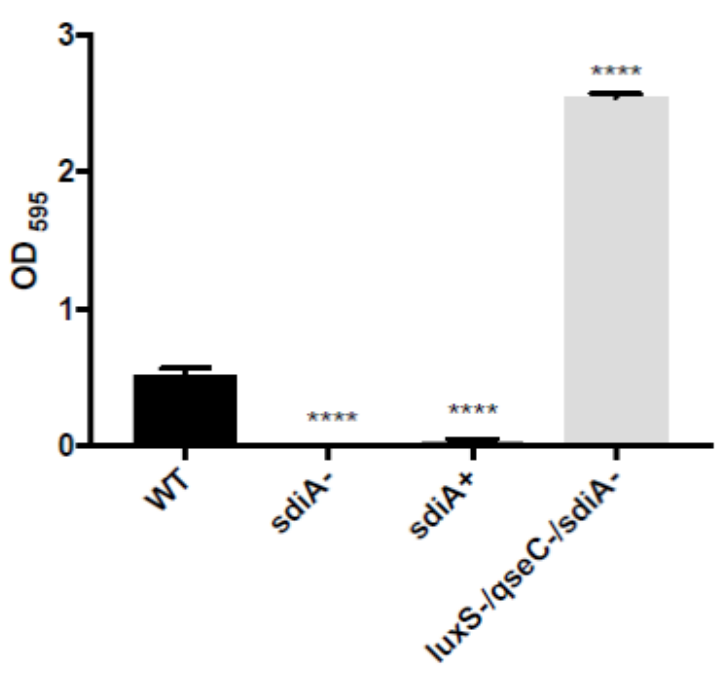

C

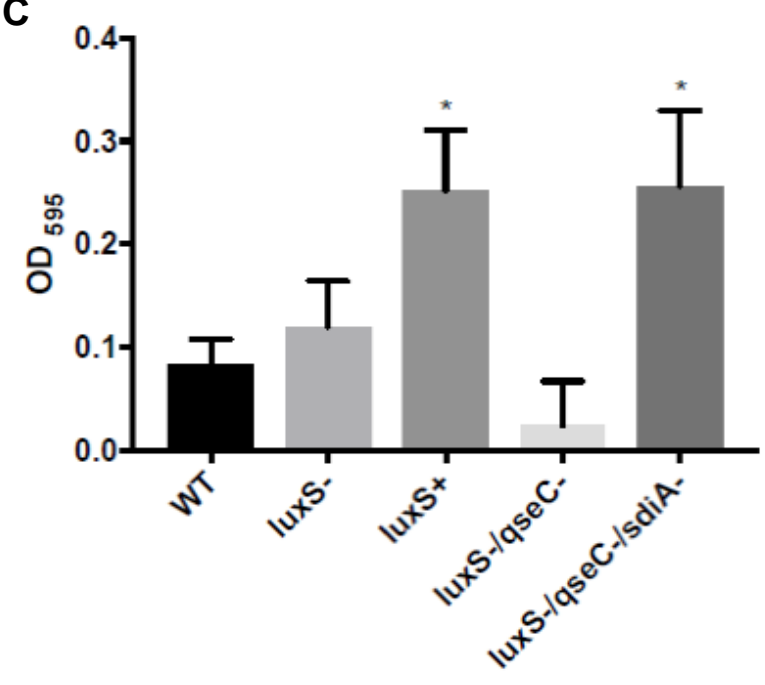

$\mathbf{E}$

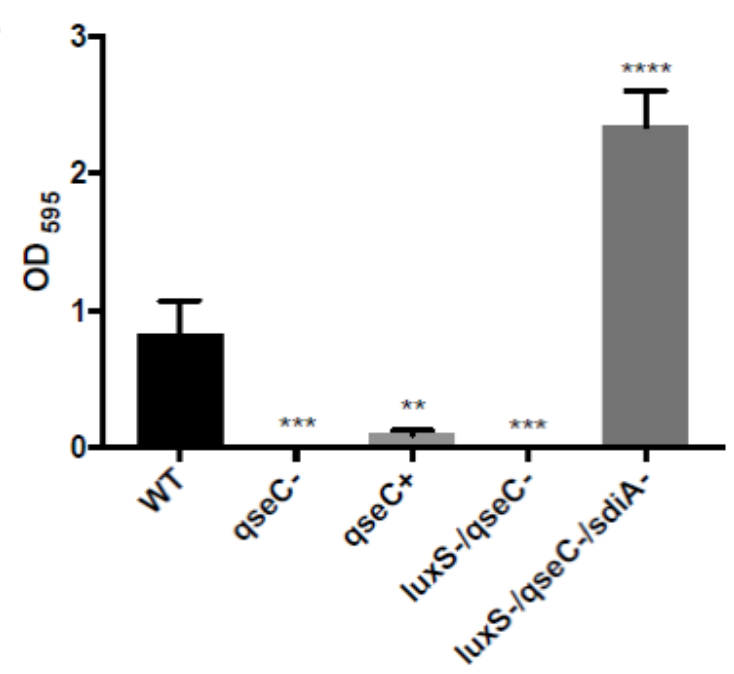

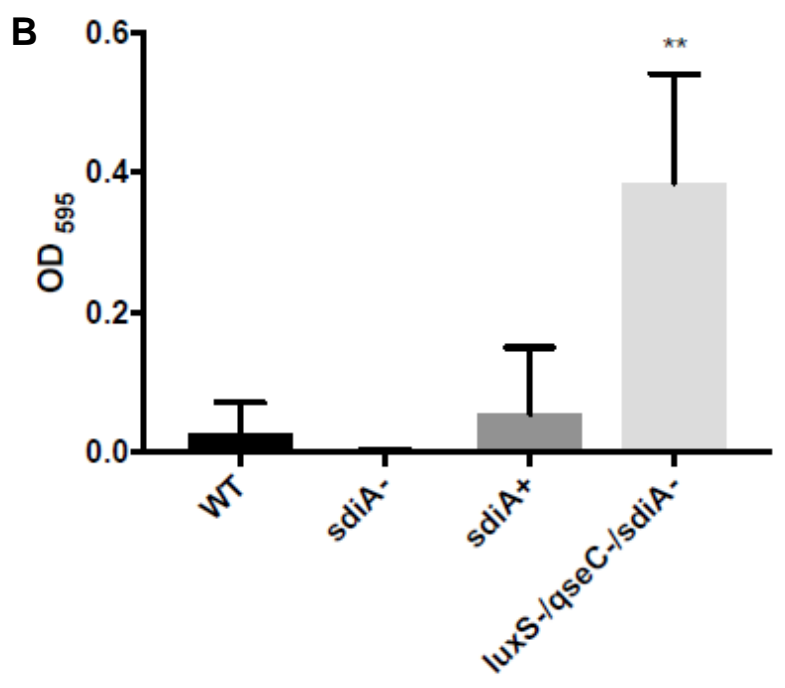

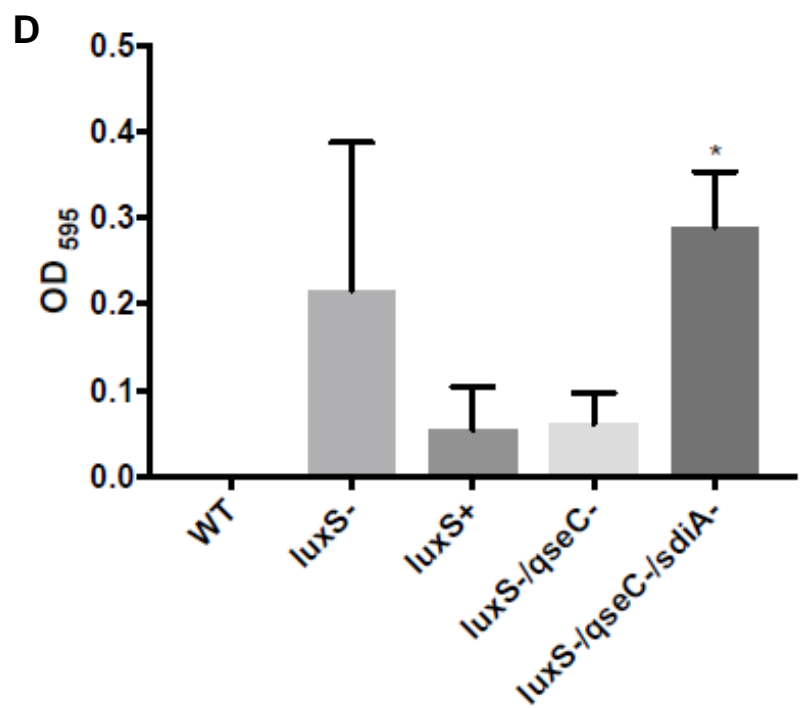

F

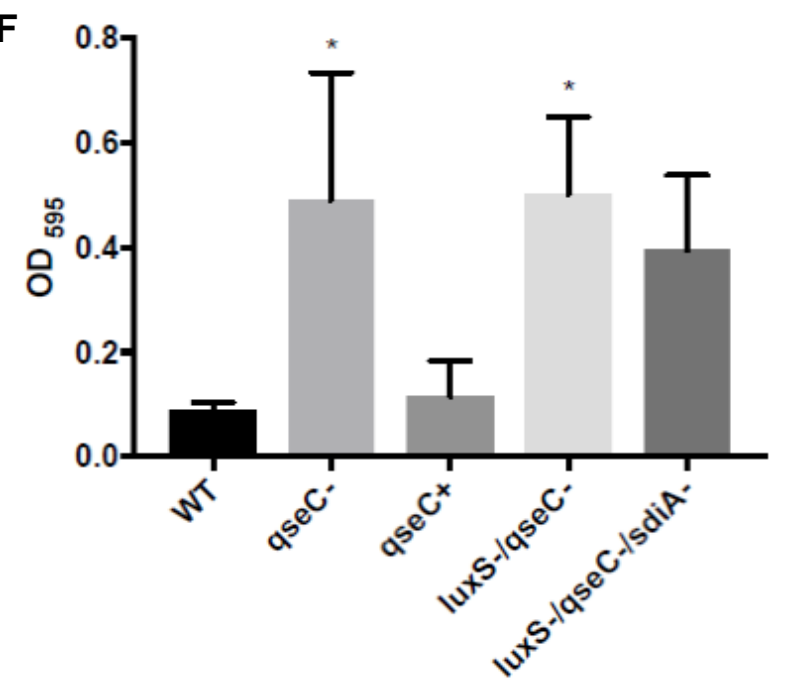

Figura 11 - Formação de biofilme em placas de poliestireno pelas amostras AP155 selvagem e mutantes, após $24 \mathrm{~h}$ de incubação em LB suplementado com moléculas autoindutoras, a $26{ }^{\circ} \mathrm{C}(\mathbf{A}, \mathbf{C}, \mathbf{E})$ e $37^{\circ} \mathrm{C}(\mathbf{B}, \mathbf{D}, \mathbf{F})$. Os valores correspondem à média de três triplicatas, mais ou menos o desvio padrão $\left({ }^{*} p<0,05 ;{ }^{* *} p<0,01 ;{ }^{* \star} p<0,001\right.$; $\left.{ }^{* * * *} p<0,0001\right)$. 
aderidas à lamínula de vidro. Um biofilme quase inexistente, com pequena quantidade de bactérias aderidas à superfície de contato, foi observado nas amostras mutante em sdiA e duplo mutante. A amostra triplo mutante produziu uma espessa camada, recobrindo toda a superfície de adesão com grandes aglomerados bacterianos.

Quando observada a $37^{\circ} \mathrm{C}$, a amostra mutante em luxS sofreu diminuição na produção de biofilme em comparação a amostra selvagem. Diferente do observado sob temperatura de $26{ }^{\circ} \mathrm{C}$, as amostras mutante em qseC e duplo mutante apresentaram um biofilme mais denso do que o observado pela amostra selvagem a $37 \stackrel{\circ}{ } \mathrm{C}$. Similar ao ocorrido com as amostras supracitadas, foi observado um incremento significativo na produção de biofilme do mutante em sdiA nesta temperatura. A amostra triplo mutante ainda foi capaz de formar uma camada de biofilme consistente, porém, menos densa do que a observada a $26{ }^{\circ} \mathrm{C}$.

Após a adição de Al-2 exógeno ao meio de cultura, foi possível observar a diminuição da produção de biofilme pelas amostras $\Delta / u x S$, duplo e triplo mutantes em ambas as temperaturas de crescimento, evidenciado por arquiteturas menos espessas e pela menor confluência entre bactérias aderidas à superfície. A presença de $\mathrm{Al}-1$ no meio de cultura, após incubação a $37^{\circ} \mathrm{C}$, resultou em maior produção de biofilme pela amostra selvagem e complementada em sdiA, e menor produção pelas amostras mutante em sdiA e triplo mutante. A adição deste $\mathrm{Al}$ ao meio de cultura após crescimento a $26 \stackrel{\circ}{\mathrm{C}}$ não alterou de forma expressiva a estrutura do biofilme das amostras testadas. A única exceção foi observada na amostra triplo mutante, que demonstrou uma leve redução no tapete de biofilme, mas ainda sendo capaz de formar um biofilme robusto. A adição de epinefrina ao meio de cultura teve uma influência negativa na formação de biofilme. As amostras selvagem e com deleções em qseC ( $\Delta q s e C$, duplo e triplo) apresentaram redução na formação dessa estrutura. Foi possível notar um maior efeito da epinefrina quando o crescimento bacteriano foi realizado sob temperatura de $37^{\circ} \mathrm{C}$. 


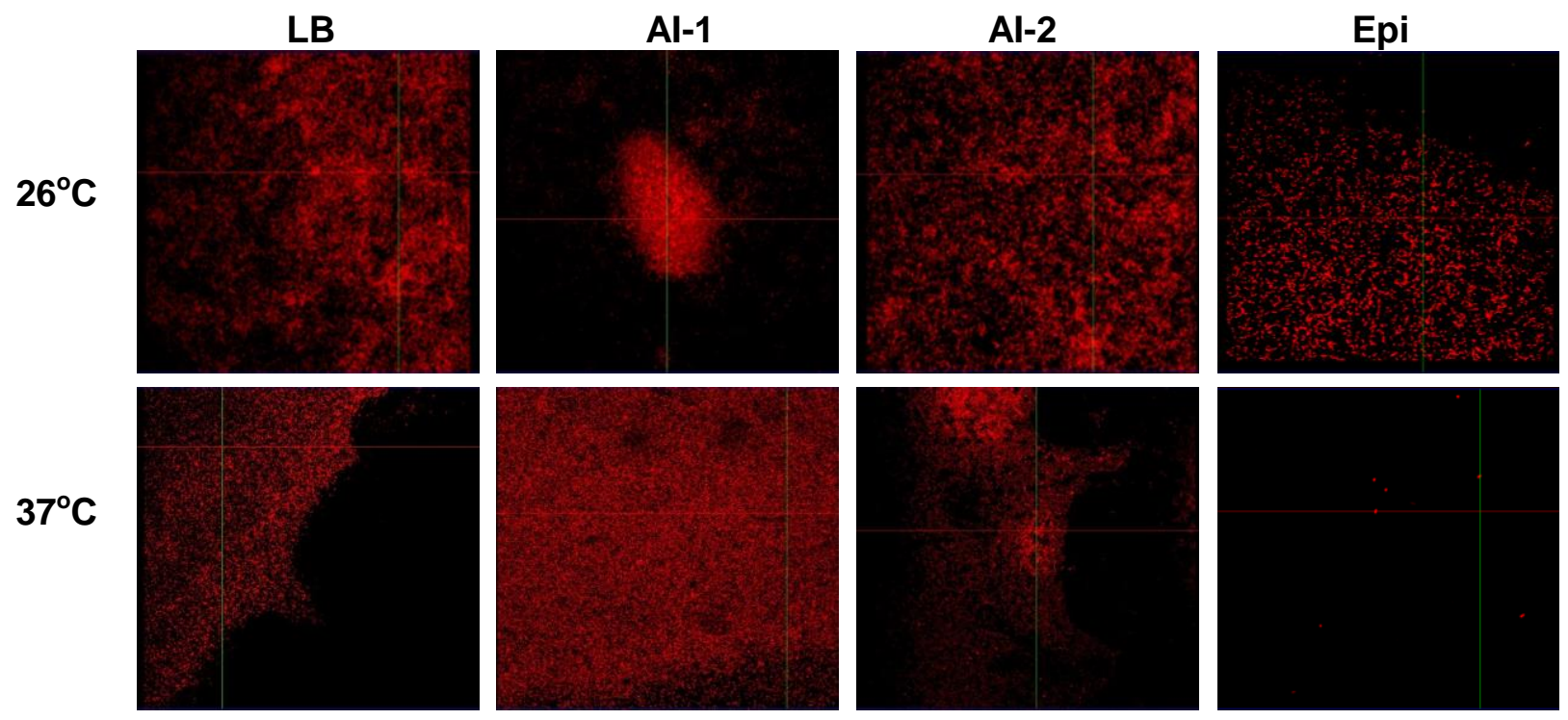

Figura 12 - Formação de biofilme em lamínulas de vidro pela amostra AP155 selvagem, após $24 \mathrm{~h}$ de incubação a $26{ }^{\circ} \mathrm{C}$ e $37^{\circ} \mathrm{C}$, na presença e ausência de moléculas autoindutoras.

A

LB
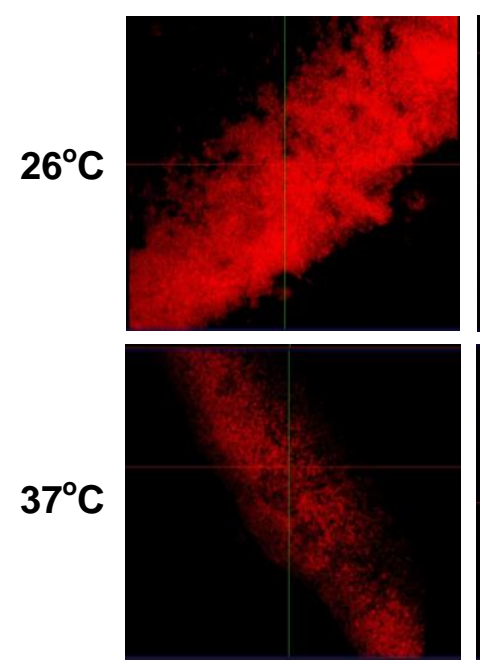

B

Al-2

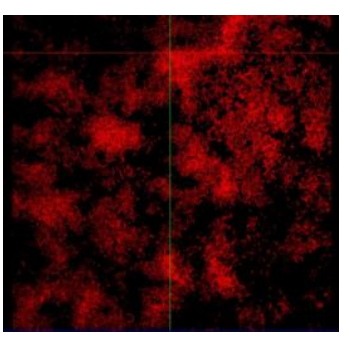

$26^{\circ} \mathrm{C}$
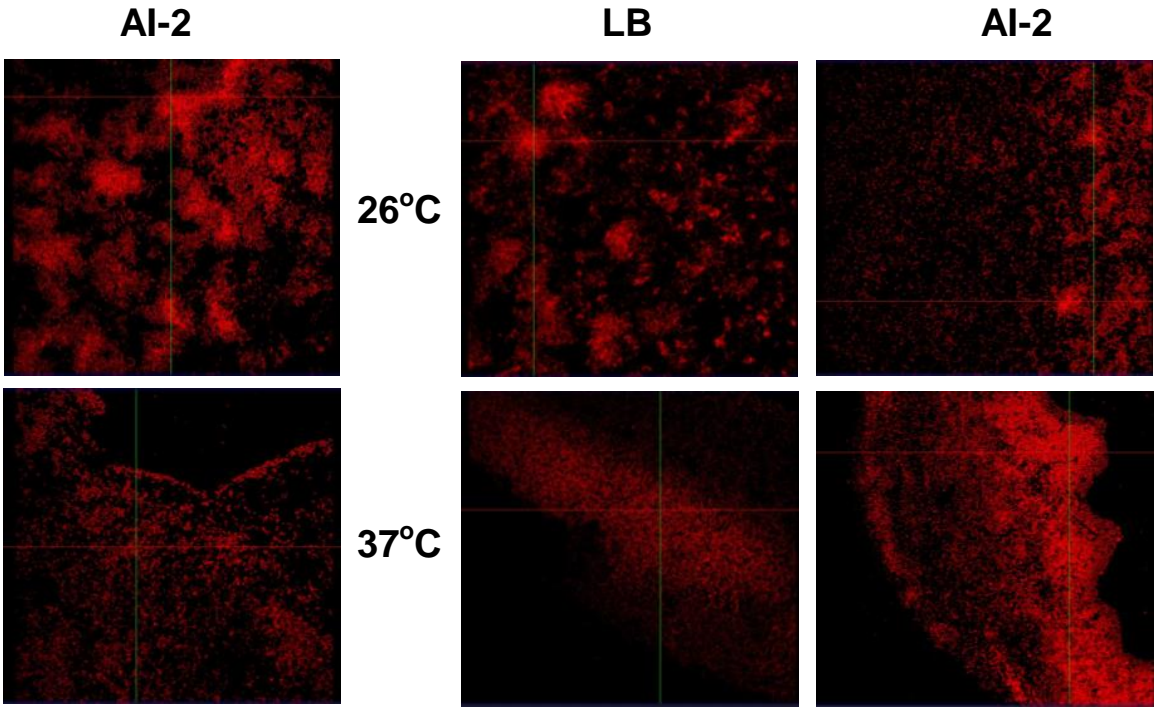

Figura 13 - Formação de biofilme em lamínulas de vidro pelas amostras AP155 $\Delta / u x S$ (A) e AP155 $\Delta / u x S+(B)$, após $24 \mathrm{~h}$ de incubação a $26{ }^{\circ} \mathrm{C}$ e $37^{\circ} \mathrm{C}$, na presença e ausência de moléculas autoindutoras. 
A

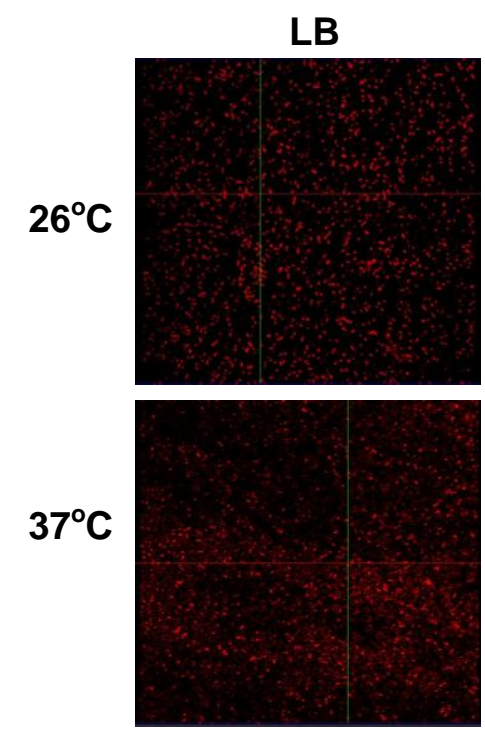

B
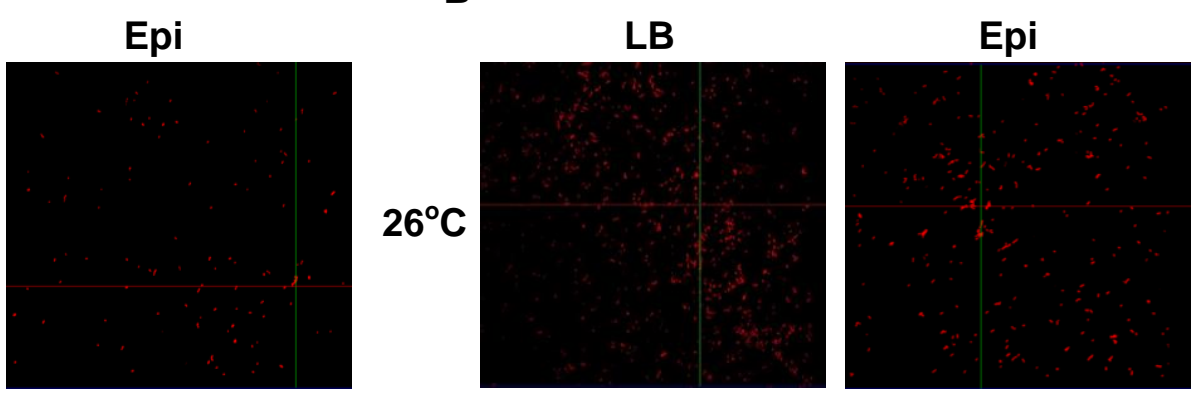

$37^{\circ} \mathrm{C}$
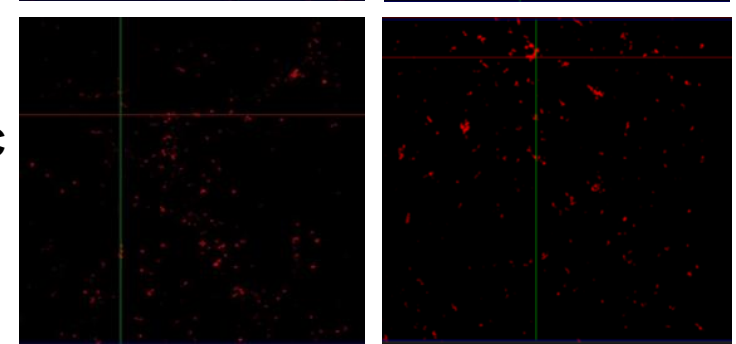

Figura 14 - Formação de biofilme em lamínulas de vidro pela amostra AP155 $\Delta q s e C(\mathrm{~A})$ e AP155 $\Delta q s e C+(B)$, após $24 \mathrm{~h}$ de incubação a $26^{\circ} \mathrm{C}$ e $37^{\circ} \mathrm{C}$, na presença e ausência de moléculas autoindutoras.

A
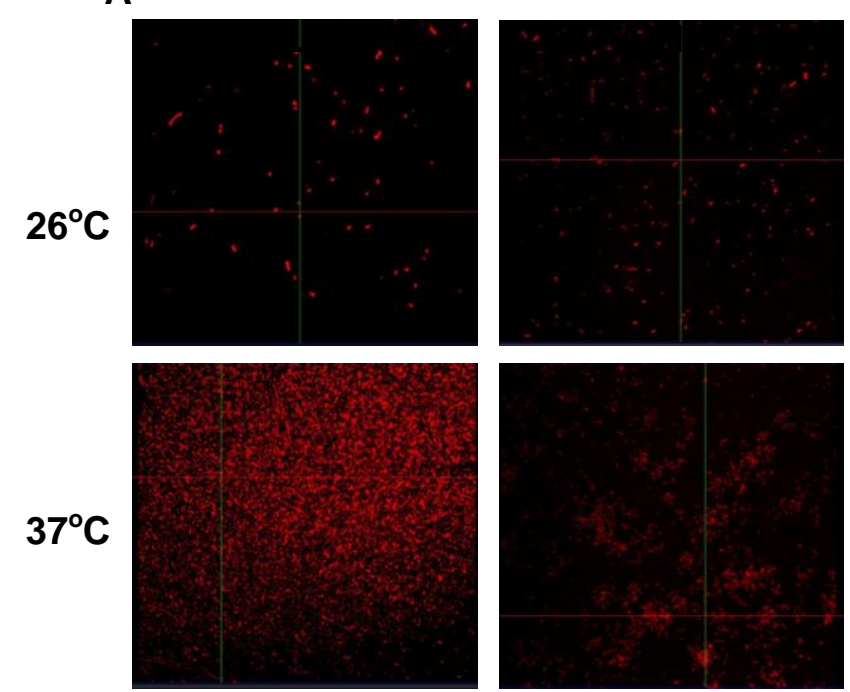

B

$26^{\circ} \mathrm{C}$
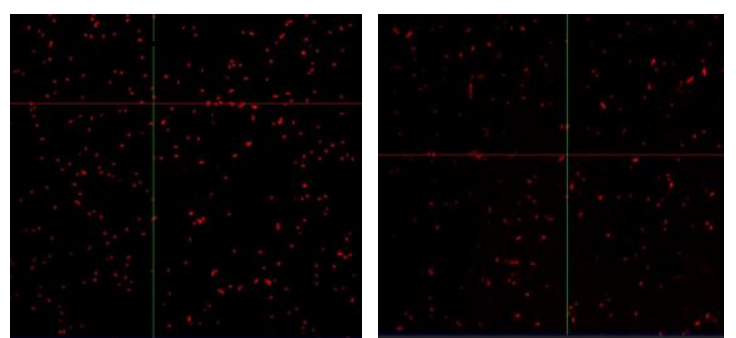

$37^{\circ} \mathrm{C}$
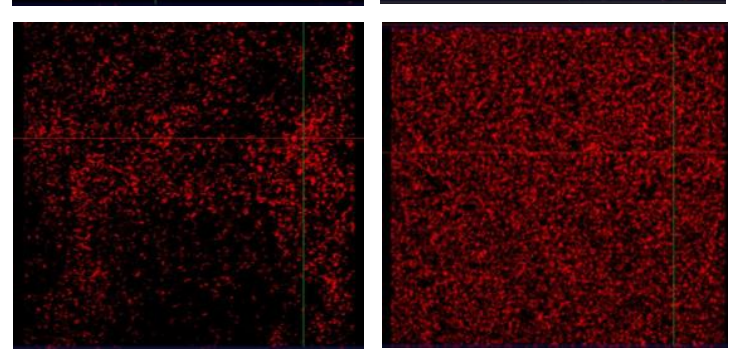

Figura 15 - Formação de biofilme em lamínulas de vidro pela amostra AP155 $\Delta s d i A(A)$ e AP155 $\Delta$ sdiA+ (B), após $24 \mathrm{~h}$ de incubação a $26{ }^{\circ} \mathrm{C}$ e $37^{\circ} \mathrm{C}$, na presença e ausência de moléculas autoindutoras. 


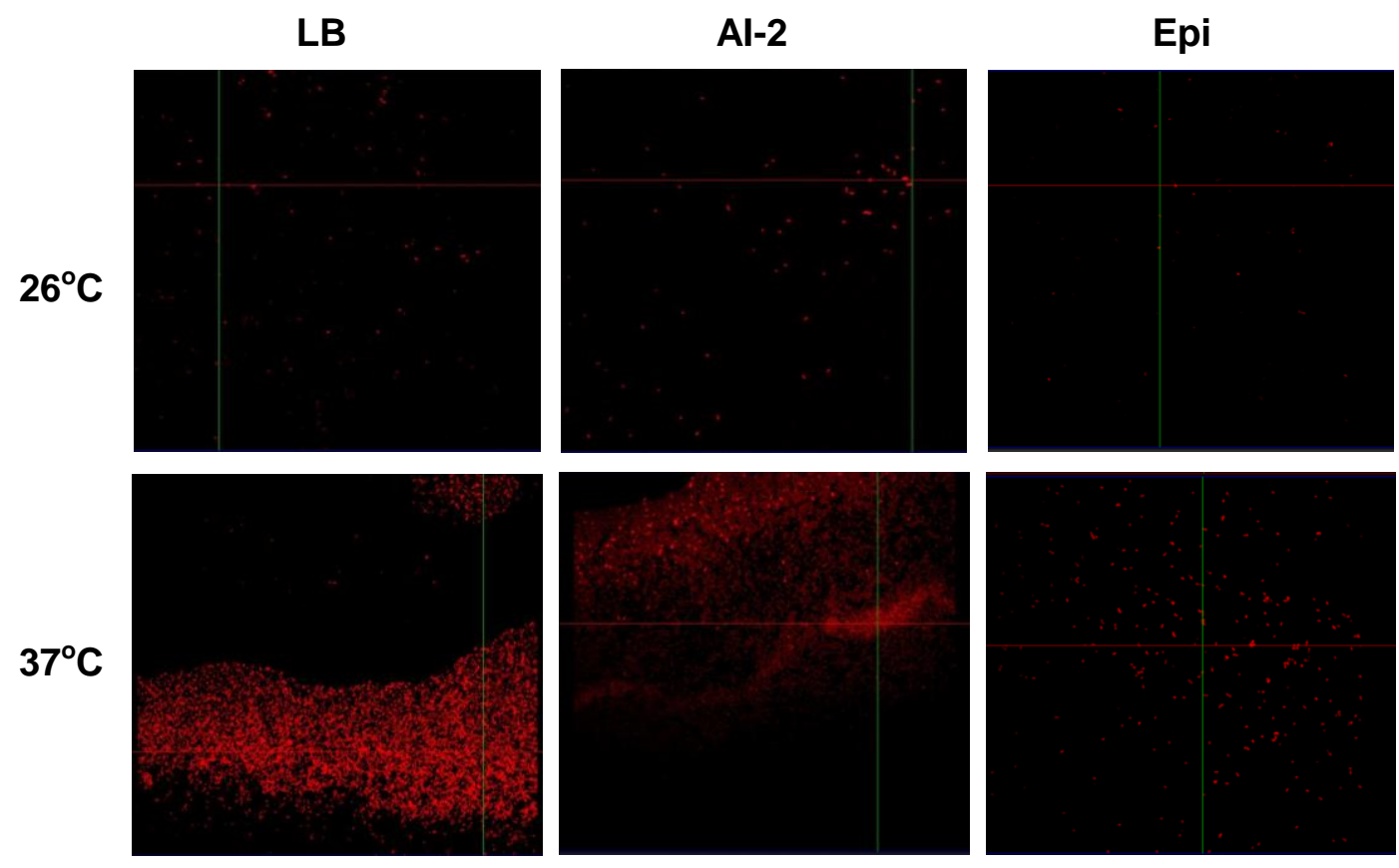

Figura 16 - Formação de biofilme em lamínulas de vidro pela amostra AP155 $\Delta /$ luxS/AqseC, após $24 \mathrm{~h}$ de incubação a $26{ }^{\circ} \mathrm{C}$ e $37^{\circ} \mathrm{C}$, na presença e ausência de moléculas autoindutoras.

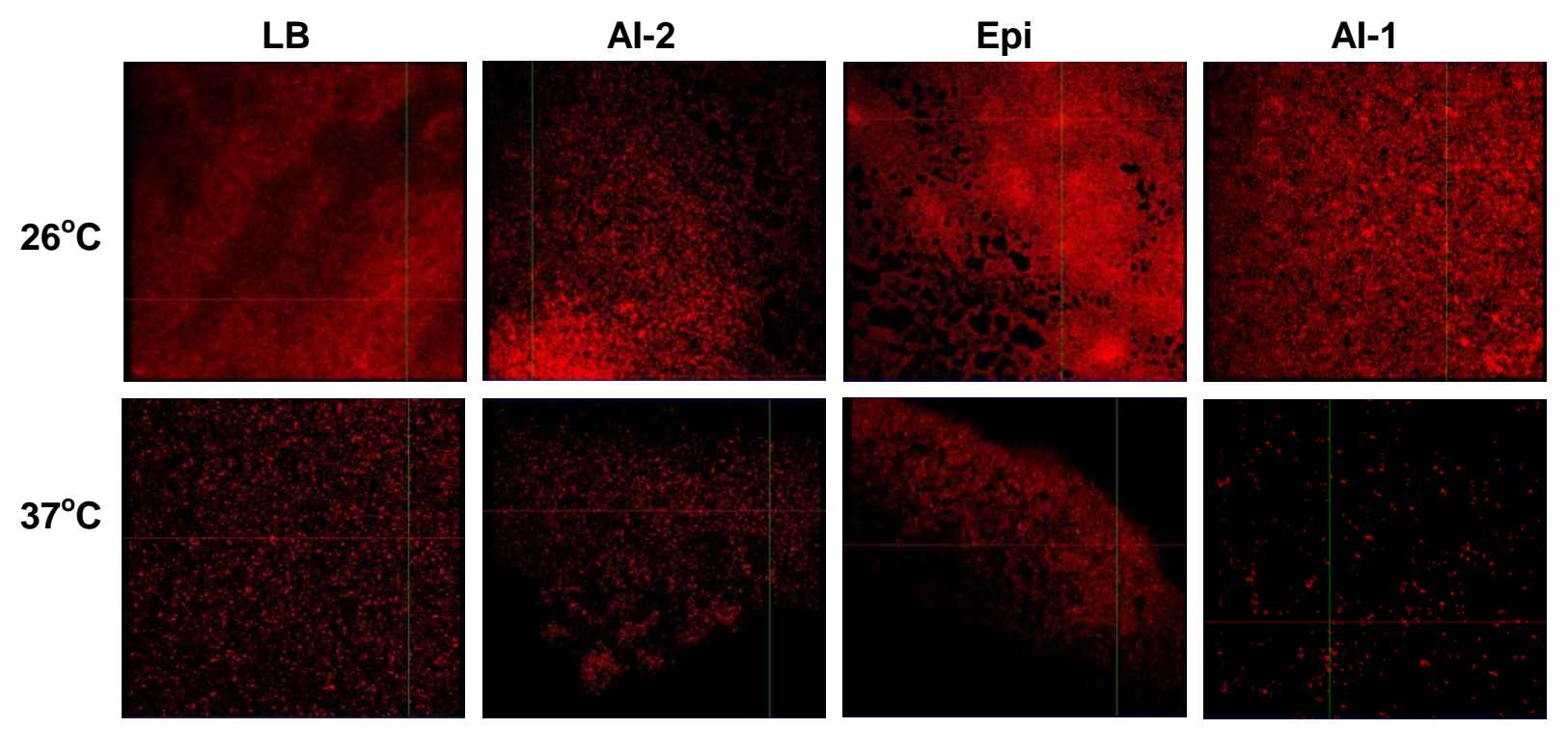

Figura 17 - Formação de biofilme em lamínulas de vidro pela amostra AP155 $\Delta / u x S / \Delta q s e C / \Delta s d i A+$, após $24 \mathrm{~h}$ de incubação a $26^{\circ} \mathrm{C}$ e $37^{\circ} \mathrm{C}$, na presença e ausência de moléculas autoindutoras. 


\subsection{Interação com células epiteliais HeLa}

5.8.1 Adesão bacteriana em células epiteliais

A adesão das amostras bacterianas em células epiteliais HeLa foi realizada através de células aderidas em lamínula de vidro (Figuras 18 a 25). Após o período de incubação de 6 horas, foi possível observar que a deleção em luxS resultou em aumento do número de bactérias aderidas tanto nas células epiteliais quanto na lamínula. Por outro lado, as amostras mutantes em qseC e sdiA demonstraram diminuição no número de bactérias aderidas em comparação com a amostra selvagem. As amostras duplo e triplo mutante também tiveram a sua capacidade de adesão comprometida, visto pela drástica diminuição de bactérias aderidas, com redução mais acentuada pela amostra triplo mutante.

A presença de Al-1 no meio de cultura resultou em aumento do número de bactérias aderidas nas células e na lamínula pela amostra selvagem. O Al-1 adicionado parece não ter surtido efeito notável na adesão da amostra mutante em sdiA. Interessantemente, a amostra triplo mutante apresentou número ligeiramente maior de bactérias aderidas às células do que a amostra $\Delta$ sdiA. $\mathrm{A}$ adição de $\mathrm{Al}-2$ exógeno diminuiu o número de bactérias aderidas pela amostra selvagem e pela amostra mutante em luxS. As amostras duplo e triplo mutante também demonstraram menor quantidade de bactérias aderidas na presença deste composto. Quando adicionada epinefrina ao meio de cultura, foi possível observar um ligeiro aumento no número de bactérias aderidas na lamínula e de microcolônias aderidas às células pela amostra selvagem. A presença deste hormônio também aumentou a adesão da amostra mutante em qseC e duplo mutante, porém, de maneira menos expressiva em comparação à amostra selvagem. Apesar de apresentar poucas bactérias aderidas às células epiteliais, a amostra triplo mutante aparentemente resultou em mais bactérias aderidas do que as outras duas ausentes em qseC.

A quantificação da adesão das amostras de estudo foi realizada através da contagem de células viáveis na forma de unidades formadoras de colônias (UFC) 
(Figuras 26 a 28). A deleção de luxS resultou em maior número de UFC em comparação a amostra selvagem. As deleções em qse $C$ e sdiA nas amostras $\triangle q s e C$ e $\Delta s d i A$, respectivamente, causaram grande redução no número de UFC. As amostras duplo e triplo mutante também sofreram grande redução na adesão. A adição de Al-1 ao meio de cultura causou aumento de UFC pela amostra selvagem, enquanto as outras amostras mutantes em sdiA não apresentaram efeitos para este Al. A adição de Al-2 resultou em redução de UFC em todas as amostras testadas com este composto. Ao adicionar Al-3 ao meio, foi possível observar aumento de UFC em todas as amostras testadas.

\subsubsection{Teste de FAS}

A avaliação da capacidade das amostras de estudo em polimerizar a actina da membrana celular eucariótica foi realizada de acordo com o teste de FAS descrito por Knutton e colaboradores (1989) (Figuras 29 a 34). A formação de pedestais de actina onde a bactéria se posiciona quando aderida à célula epitelial é característica do desenvolvimento da lesão A/E e indica positividade para este fenótipo.

A amostra selvagem apresentou capacidade moderada na formação de pedestais, enquanto a deleção em luxS parece aumentar a formação dessa estrutura pela amostra $\Delta l u x S$. A deleção de $q s e C$ e sdiA resultou em pouco número de bactérias formando pedestais, visto pela adesão realizada pelas amostras $\Delta q s e C$ e $\Delta s d i A$, respectivamente. As amostras duplo e triplo mutante geraram resultados similares, ambas as amostras demonstraram pouca formação de pedestais.

$\mathrm{Na}$ presença de Als, foi possível observar que a adição de Al-1 aumentou a formação de pedestais pelas amostras selvagem e $\Delta s d i A^{+}$, mas parece não ter surtido efeito nas amostras com deleção em $\operatorname{sdiA}(\Delta s d i A$ e triplo). De maneira oposta, o Al-2 adicionado ao meio de cultura diminuiu a formação de pedestais pelas amostras selvagem e com deleções em luxS ( $\Delta / u x S$, duplo e triplo). O efeito da epinefrina na formação de pedestais foi o de maior influência positiva entre os Als utilizados. Tanto amostras contendo o gene qseC (selvagem e $\Delta q s e C^{+}$) quanto amostras com deleções neste gene ( $\Delta q s e C$, duplo e triplo) apresentaram aumento no número de pedestais formados. 


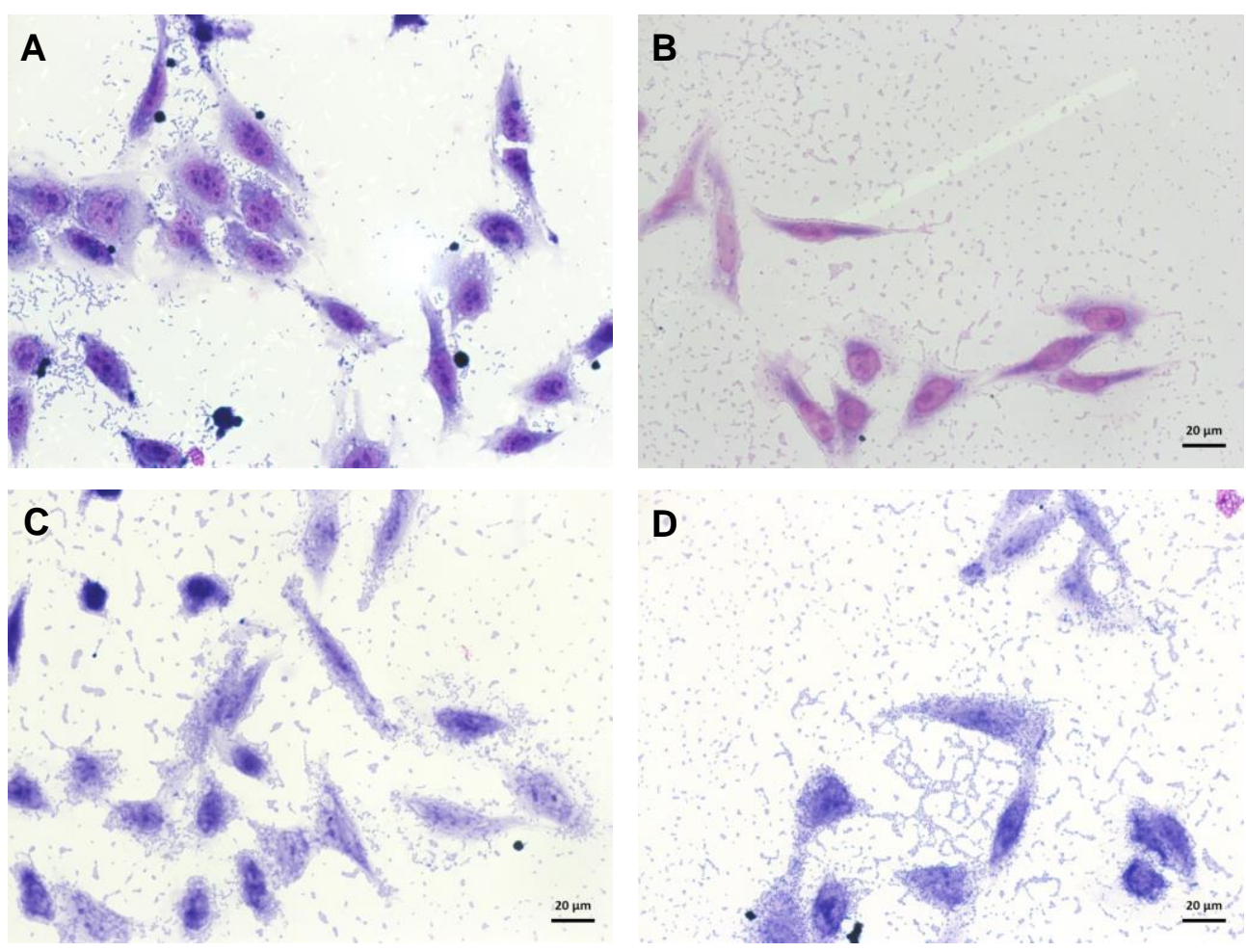

Figura 18 - Interação da amostra AP155 selvagem com células HeLa, na ausência (A) e presença de Al-2 (B), Al-1 (C) e Epi (D), em ensaios de $6 \mathrm{~h}$. As células foram fixadas com metanol, coradas com May-Grünwald $0,2 \%$ e Giemsa 1:3 e visualizadas através de microscopia óptica em aumento de 600X.
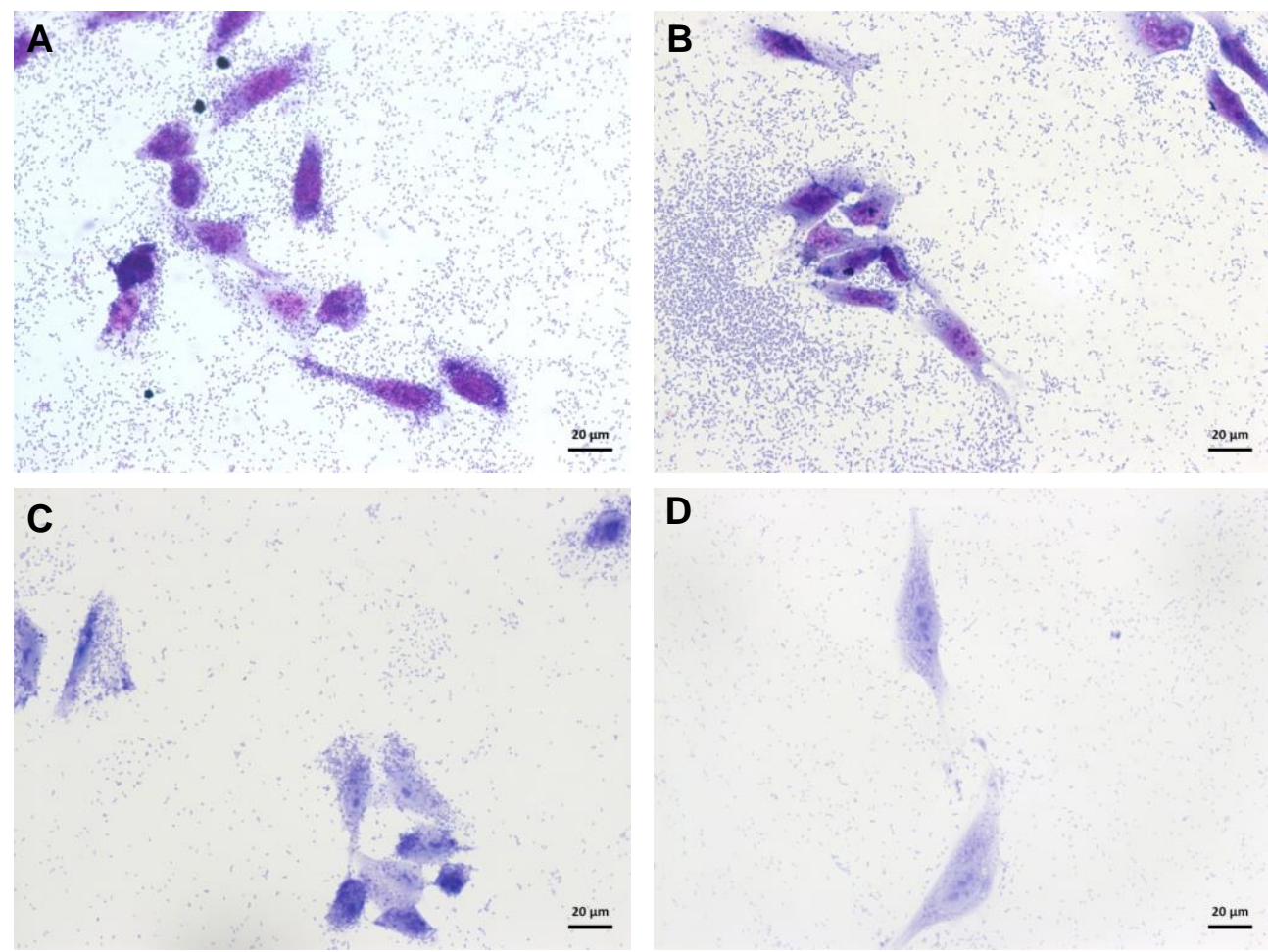

D

Figura 19 - Interação das amostras AP155 $\Delta / u x S$ (A, C) e AP155 $\Delta / u x S+$ (B, D) com células HeLa, na ausência (A, B) e presença de Al-2 (C, D), em ensaios de $6 \mathrm{~h}$. As células foram fixadas com metanol, coradas com May-Grünwald 0,2\% e Giemsa 1:3 e visualizadas através de microscopia óptica em aumento de $600 \mathrm{X}$. 


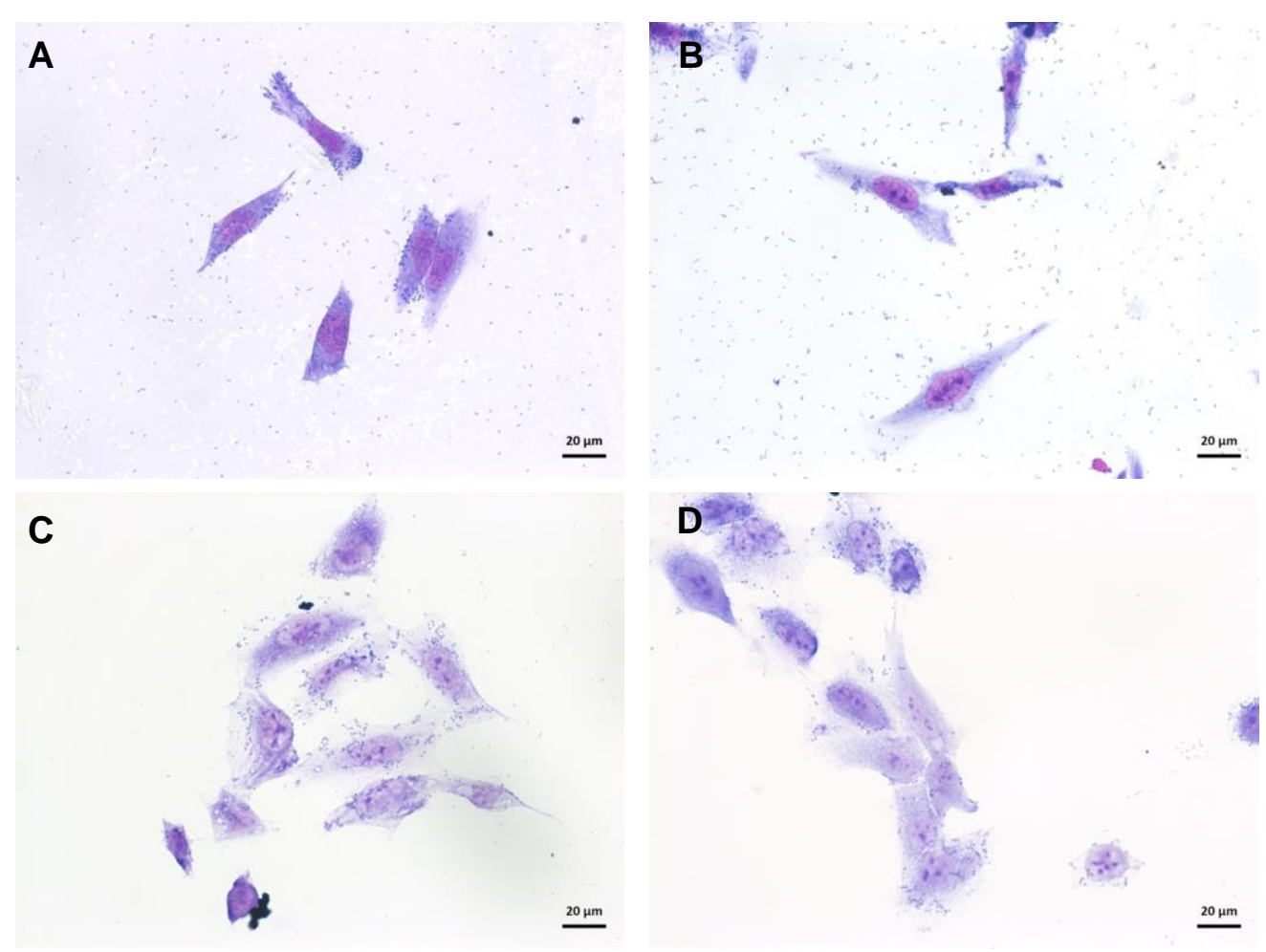

Figura 20 - Interação das amostras AP155 $\Delta$ qseC (A, C) e AP155 $\Delta q s e C+$ (B, D) com células HeLa, na ausência (A, B) e presença de Epi (C, D), em ensaios de $6 \mathrm{~h}$. As células foram fixadas com metanol, coradas com May-Grünwald 0,2\% e Giemsa 1:3 e visualizadas através de microscopia óptica em aumento de $600 \mathrm{X}$.

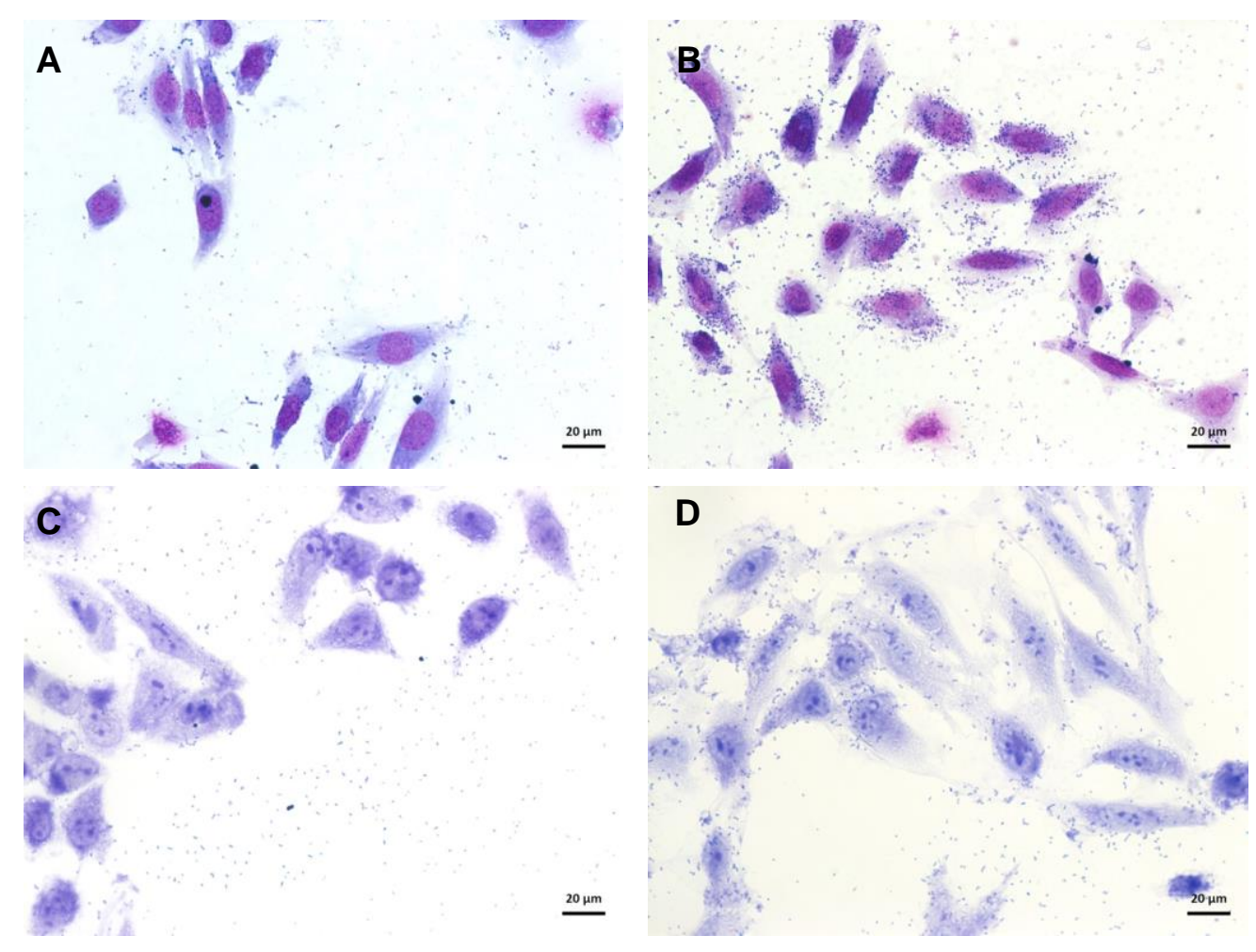

Figura 21 - Interação das amostras AP155 $\Delta$ sdiA (A, C) e AP155 $\Delta$ sdiA+ (B, D) com células HeLa, na ausência (A, B) e presença de Al-1 (C, D), em ensaios de $6 \mathrm{~h}$. As células foram fixadas com metanol, coradas com May-Grünwald 0,2\% e Giemsa 1:3 e visualizadas através de microscopia óptica em aumento de $600 \mathrm{X}$. 


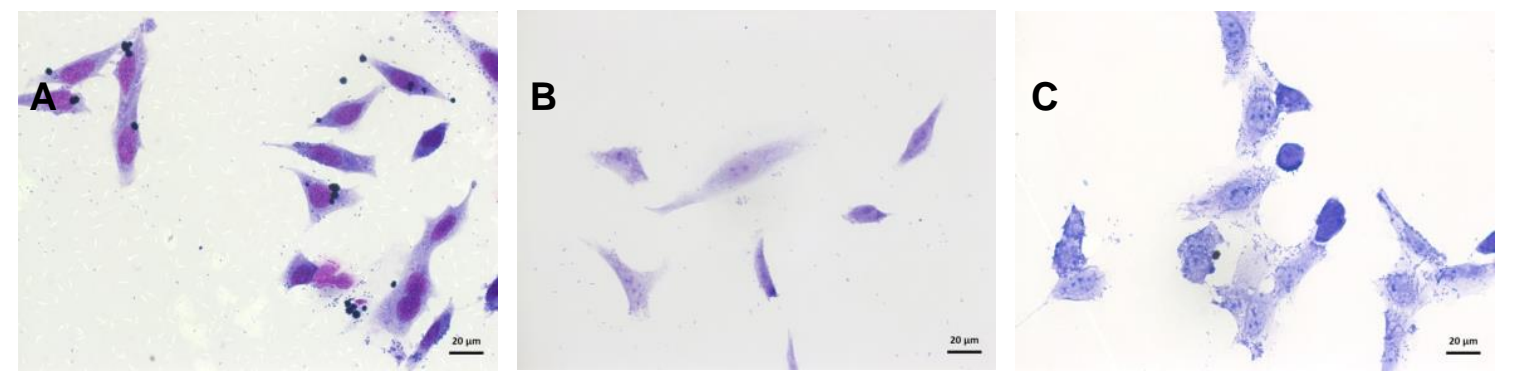

Figura 22 - Interação da amostra AP155 $\Delta l u x S / \Delta q s e C$ com células HeLa, na ausência (A) e presença de Al-2 (B) e Epi (C), em ensaios de $6 \mathrm{~h}$. As células foram fixadas com metanol, coradas com May-Grünwald $0,2 \%$ e Giemsa 1:3 e visualizadas através de microscopia óptica em aumento de $600 \mathrm{X}$.

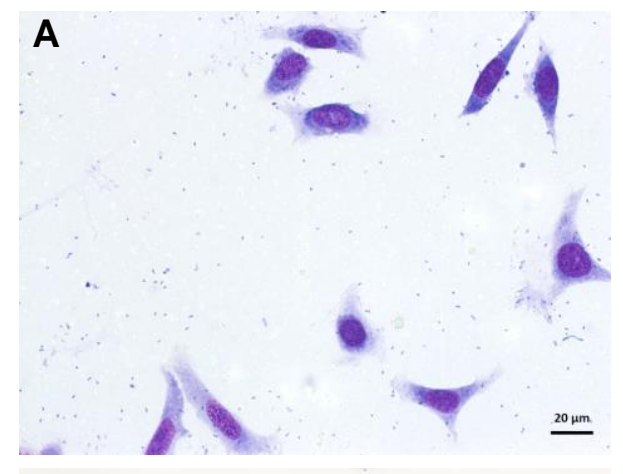

B

C
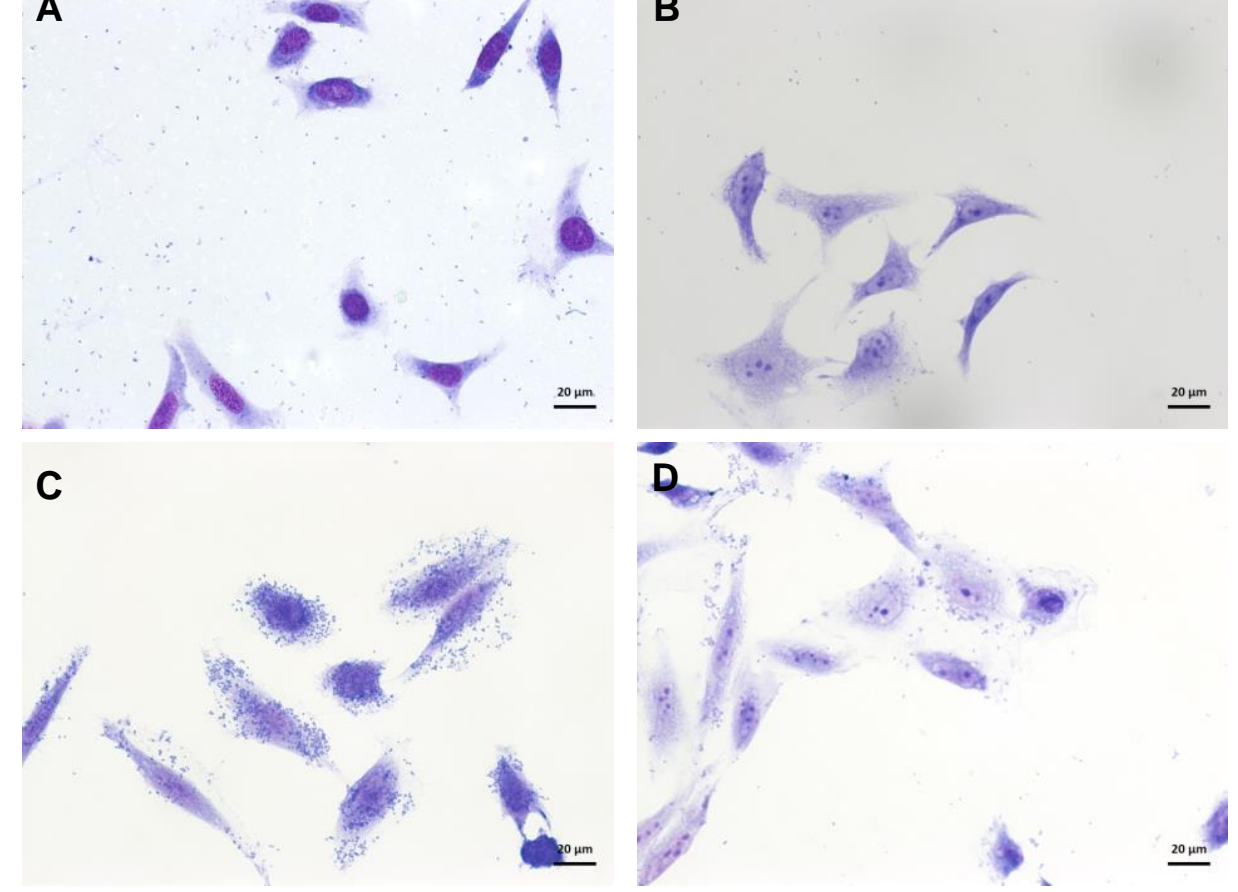

Figura 23 - Interação da amostra AP155 $\Delta / u x S / \Delta q s e C / \Delta s d i A$ com células HeLa, na ausência (A) e presença de Al-2 (B), Al-1 (C) e Epi (D), em ensaios de $6 \mathrm{~h}$. As células foram fixadas com metanol, coradas com May-Grünwald 0,2\% e Giemsa 1:3 e visualizadas através de microscopia óptica em aumento de $600 \mathrm{X}$. 


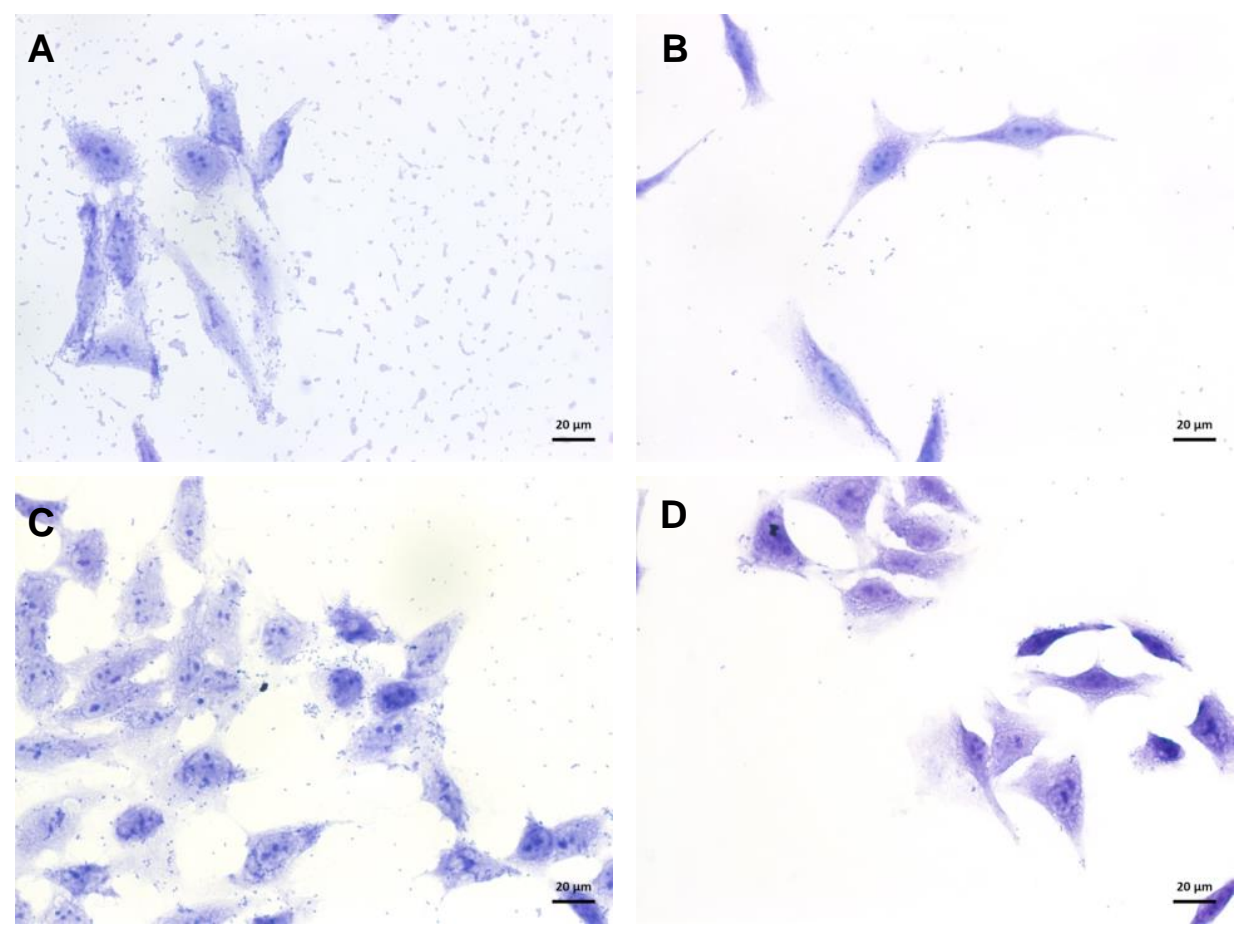

Figura 24 - Controles dos ensaios de interação com células HeLa, na presença de DMSO, em ensaios de $6 \mathrm{~h}$. AP155 selvagem (A), AP155 $\Delta s d i A$ (B), AP155 $\Delta s d i A+($ C) e Epi (D). As células foram fixadas com metanol, coradas com May-Grünwald 0,2\% e Giemsa 1:3 e visualizadas através de microscopia óptica em aumento de $600 \mathrm{X}$.

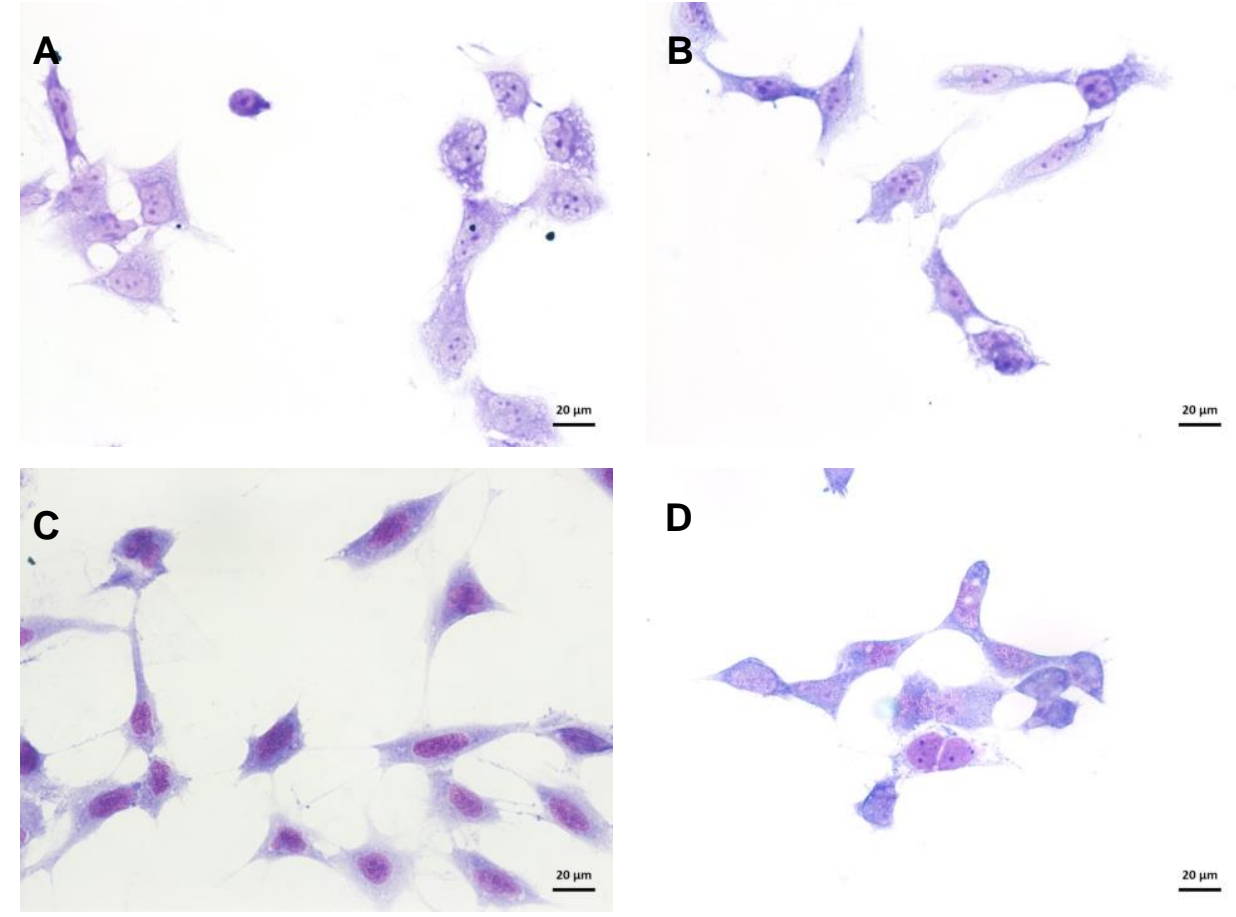

Figura 25 - Controles celulares dos ensaios de interação. DMEM (A), Al-2 (B), Al-1 (C) e AP155 $\Delta / u x S / \Delta q s e C / \Delta s d i A$ (D). As células foram fixadas com metanol, coradas com MayGrünwald $0,2 \%$ e Giemsa 1:3 e visualizadas através de microscopia óptica em aumento de $600 \mathrm{X}$. 


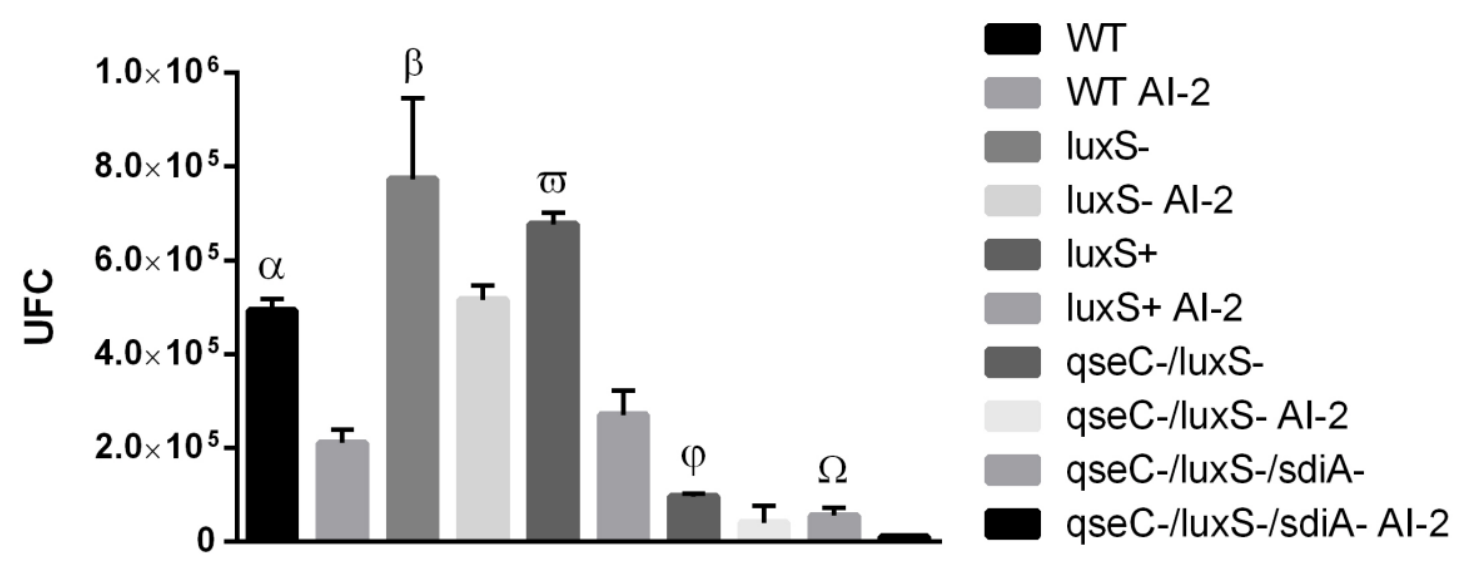

Figura 26 - Quantificação da adesão das amostras AP155 selvagem e mutantes com células HeLa, na ausência e presença de Al-2, em ensaios de $6 \mathrm{~h}$, através da determinação da UFC. Os valores correspondem à média de três triplicatas, mais ou menos o desvio padrão $(p<0,05)$.

$\alpha=$ WT $x$ WT Al-2, luxS-, qseC-/luxS-, qseC-/luxS-/sdiA-

$\beta=\operatorname{luxS}-x \operatorname{lu} x \mathrm{~S}-\mathrm{Al}-2$

$\varpi=\operatorname{luxS}+x \operatorname{luxS}+\mathrm{Al}-2$

$\varphi=$ qseC-/luxS- $x$ qseC-/luxS- Al-2

$\Omega=q s e C-/ l u x S-/ s d i A-x$ qseC-/luxS-/sdiA- Al-2

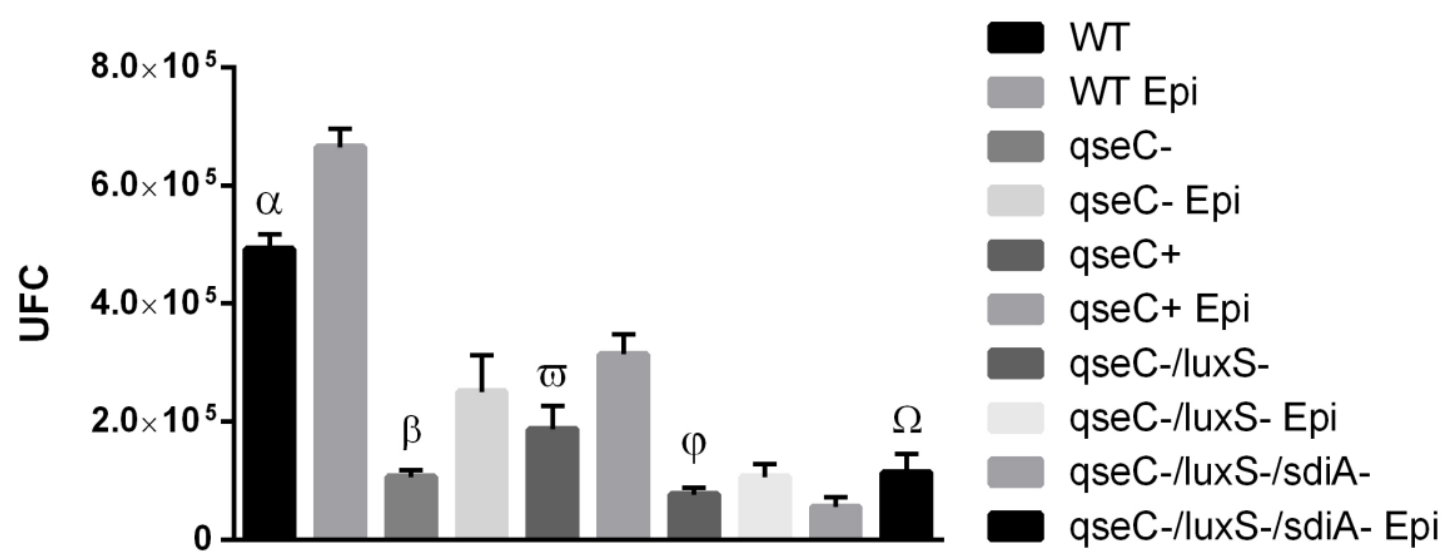

Figura 27 - Quantificação da adesão das amostras AP155 selvagem e mutantes com células HeLa, na ausência e presença de Epi, em ensaios de 6 h, através da determinação da UFC. Os valores correspondem à média de três triplicatas, mais ou menos o desvio padrão $(p<0,05)$.

$\alpha=$ WT x WT Epi, qseC-, qseC+, qseC-/luxS-, qseC-/luxS-/sdiA-

$\beta=$ qseC $-x$ qseC- Epi

$\varpi=q s e C+x q s e C+E p i$

$\varphi=$ qseC-/luxS- x qseC-/luxS- Epi

$\Omega=q s e C-/ l u x S-/ s d i A-x$ qseC-/luxS-/sdiA- Epi 


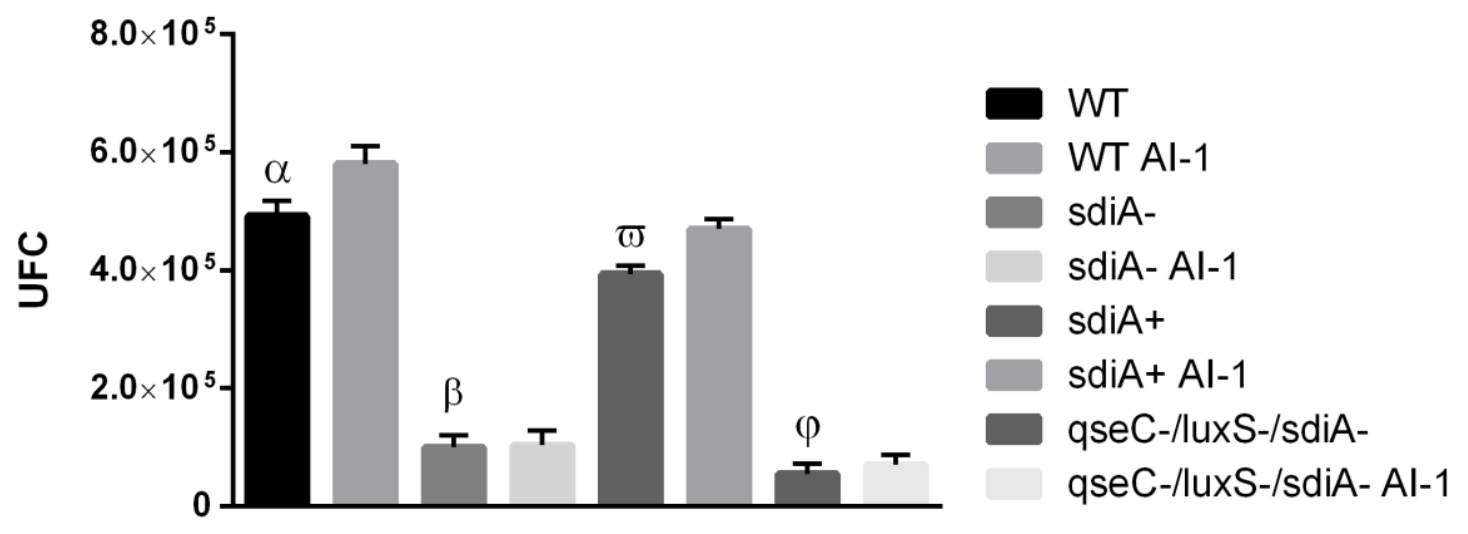

Figura 28 - Quantificação da adesão das amostras AP155 selvagem e mutantes com células HeLa, na ausência e presença de Al-1, em ensaios de $6 \mathrm{~h}$, através da determinação da UFC. Os valores correspondem à média de três triplicatas, mais ou menos o desvio padrão $(p<0,05)$.

$\alpha=$ WT $x$ WT Al-1, sdiA-, sdiA+, qseC-/luxS-/sdiA-

$\beta=\operatorname{sdi} A-x$ sdiA $-A l-1$

$\varpi=\operatorname{sdi} A+x \operatorname{sdi} A+A l-1$

$\varphi=$ qseC-/luxS-/sdiA- x qseC-/luxS-/sdiA- Al-1 

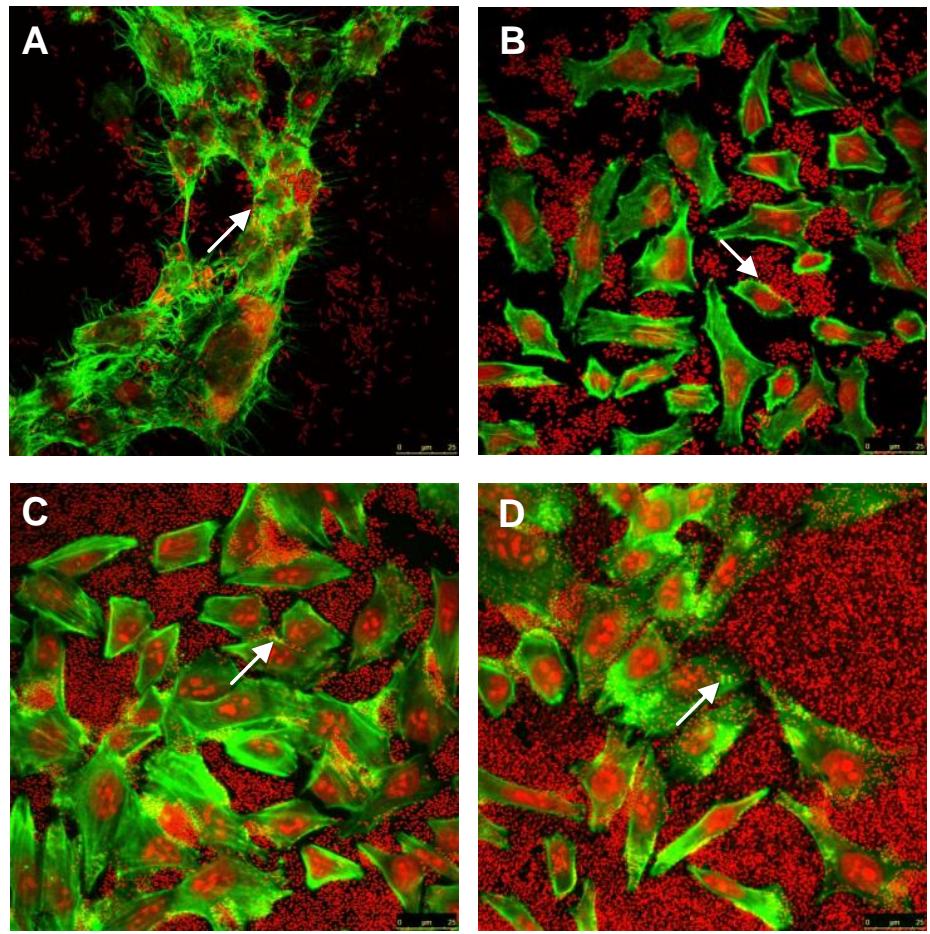

Figura 29 - Análise da formação da lesão A/E pela amostra AP155 selvagem em células HeLa, em ensaios de $6 \mathrm{~h}$, na ausência (A) e presença de Al-2 (B), Al-1 (C) e Epi (D). As células foram duplamente marcadas com FITC-faloidina $(5 \mu \mathrm{g} / \mathrm{mL})$ e lodeto de Propídio (1:1000) e visualizadas através de Microscopia Confocal de Fluorescência em aumento de $630 \mathrm{X}$.
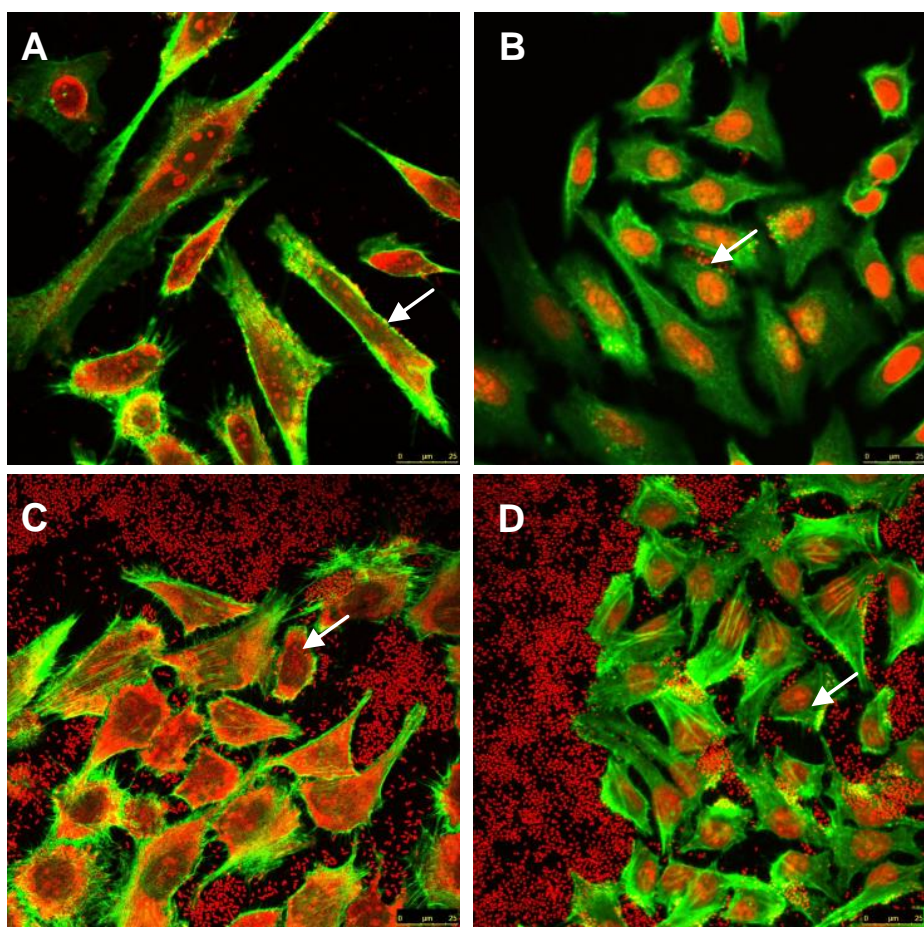

Figura 30 - Análise da formação da lesão A/E pelas amostras AP155 $\Delta / u x S(A, C)$ e AP155 $\Delta / u x S+(B, D)$ em células HeLa, em ensaios de $6 \mathrm{~h}$, na ausência $(\mathbf{A}, \mathbf{B})$ e presença de Al-2 (C, D). As células foram duplamente marcadas com FITC-faloidina $(5 \mu \mathrm{g} / \mathrm{mL})$ e lodeto de Propídio (1:1000) e visualizadas através de Microscopia Confocal de Fluorescência em aumento de $630 \mathrm{X}$. 

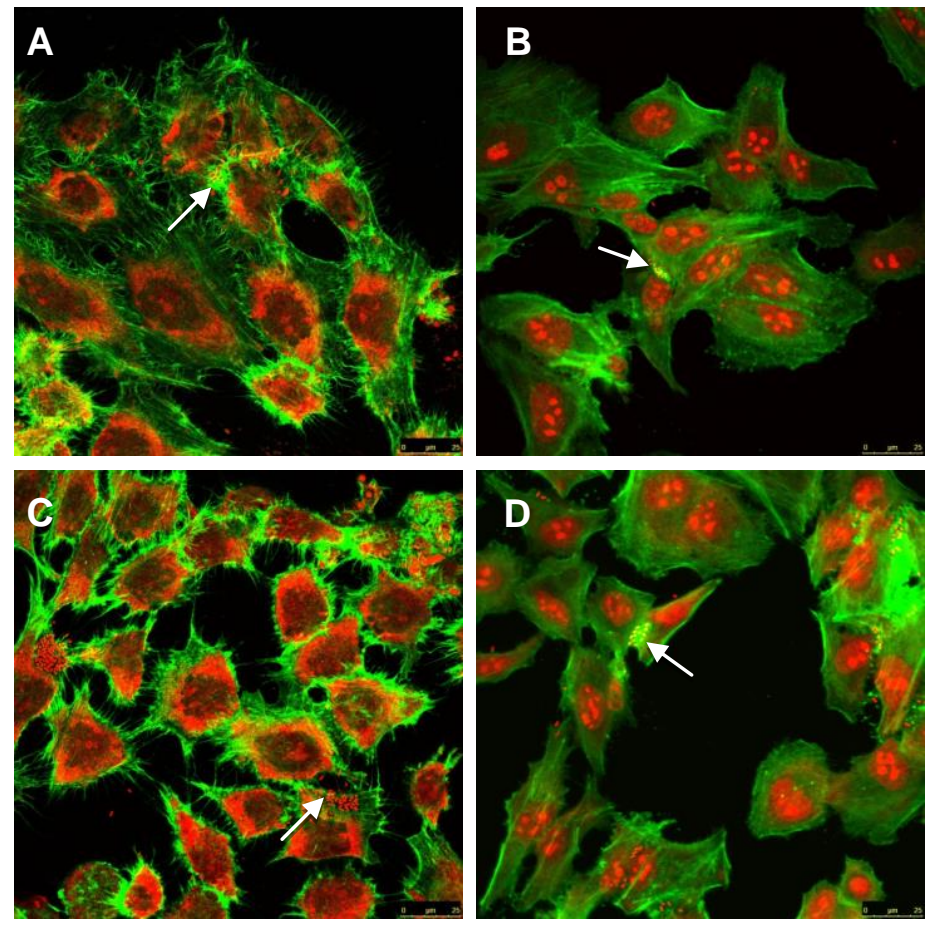

Figura 31 - Análise da formação da lesão A/E pelas amostras AP155 $\Delta$ qseC (A, C) e AP155 $\Delta q s e C+(B, D)$ em células HeLa, em ensaios de $6 \mathrm{~h}$, na ausência $(\mathbf{A}, \mathbf{B})$ e presença de Epi (C, D). As células foram duplamente marcadas com FITC-faloidina $(5 \mu \mathrm{g} / \mathrm{mL})$ e lodeto de Propídio (1:1000) e visualizadas através de Microscopia Confocal de Fluorescência em aumento de $630 \mathrm{X}$.
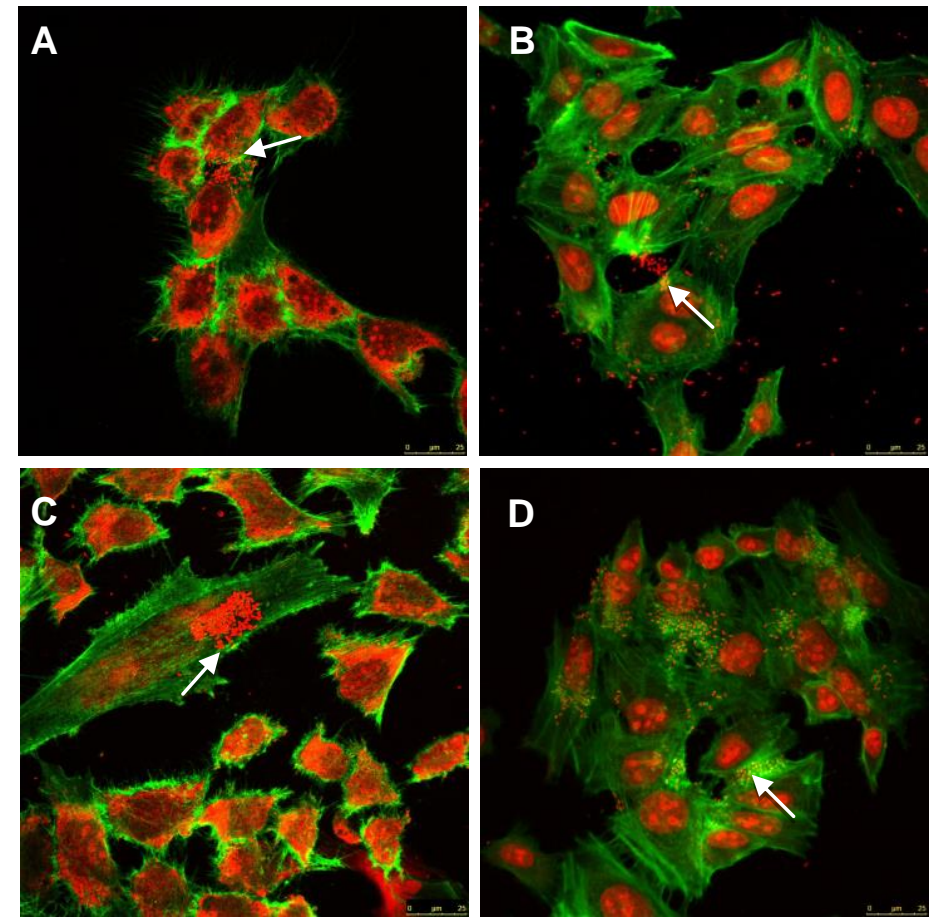

Figura 32 - Análise da formação da lesão A/E pelas amostras AP155 $\Delta$ sdiA (A, C) e AP155 $\Delta s d i A+(B, D)$ em células HeLa, em ensaios de $6 \mathrm{~h}$, na ausência (A, B) e presença de Al-1 (C, D). As células foram duplamente marcadas com FITC-faloidina $(5 \mu \mathrm{g} / \mathrm{mL})$ e lodeto de Propídio (1:1000) e visualizadas através de Microscopia Confocal de Fluorescência em aumento de $630 \mathrm{X}$. 

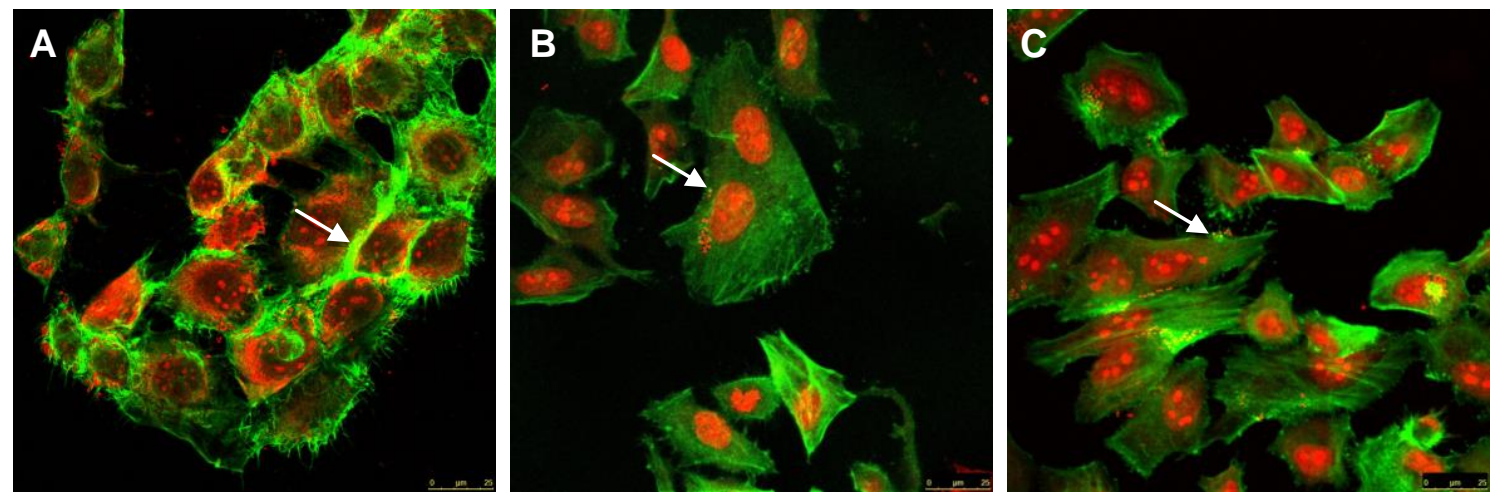

Figura 33 - Análise da formação da lesão A/E pela amostra AP155 $\Delta / u x S / \Delta q s e C$ em células HeLa, em ensaios de 6 h, na ausência (A) e presença de Al-2 (B) e Epi (C). As células foram duplamente marcadas com FITC-faloidina $(5 \mu \mathrm{g} / \mathrm{mL})$ e lodeto de Propídio (1:1000) e visualizadas através de Microscopia Confocal de Fluorescência em aumento de $630 \mathrm{X}$.
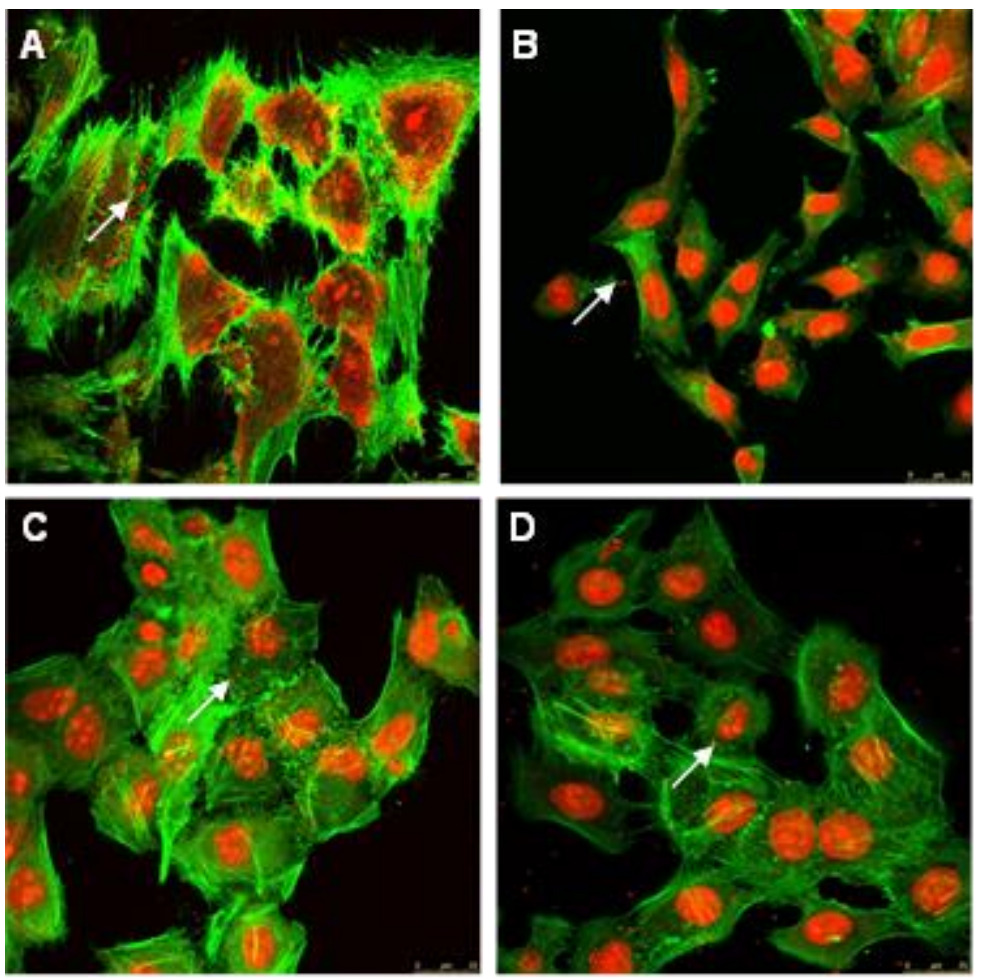

Figura 34 - Análise da formação da lesão A/E pela amostra AP155 $\Delta / u x S / \Delta q s e C / \Delta s d i A$ em células HeLa, em ensaios de $6 \mathrm{~h}$, na ausência (A) e presença de Al-2 (B), Epi (C) e Al-1 (D). As células foram duplamente marcadas com FITC-faloidina $(5 \mu \mathrm{g} / \mathrm{mL})$ e lodeto de Propídio $(1: 1000)$ e visualizadas através de Microscopia Confocal de Fluorescência em aumento de $630 \mathrm{X}$. 


\subsection{PCR em Tempo Real}

A quantificação da transcrição de genes de interesse foi realizada através da técnica de PCR em Tempo Real. O gene rpoA foi utilizado como controle de transcrição endógeno para normalizar as reações e a amostra selvagem foi utilizada como referência para quantificação relativa da transcrição.

Os genes fliC, bcs $A, \operatorname{csg} D$ e $\operatorname{csg} A$ estão envolvidos em processos celulares como movimentação flagelar, adesão à superfícies e produção de matriz extrapolimérica. Observa-se na figura 35 que todas as amostras mutantes sofreram redução na transcrição de $f l i C$, com $\Delta / u x S$ apresentando os menores níveis transcricionais e a amostra mutante duplo uma relação duas vezes menor do que os níveis obtidos pela amostra selvagem. A transcrição de bcs $A$ foi reduzida em todas amostras mutantes, com $\Delta s d i A$ e triplo mutante apresentando os menores níveis. $A$ análise da transcrição de $\operatorname{csg} D$ e $\operatorname{csg} A$ apresentaram resultados similares, demonstrando baixos níveis transcricionais para as amostras mutantes, principalmente para $\Delta q s e C$.

Os genes fimA, ler, eae e espA participam de processos de adesão e infecção em células do hospedeiro. É possível observar na figura 36 que as amostras mutantes não apresentaram níveis de transcrição para o gene $\operatorname{fim} A$. A transcrição do gene ler sofreu leve redução em todas as amostras mutantes, com a amostra $\Delta s d i A$ e triplo mutante apresentando os menores níveis transcricionais. O gene eae apresentou maiores níveis de transcrição na amostra mutante em luxS, e níveis menores na amostra mutante em sdiA. O restante de amostras mutantes não sofreu alterações significativas. A amostra mutante em luxS também apresentou níveis maiores de transcrição do gene espA, um resultado similar foi observado para o mutante duplo. O mutante em sdiA também sofreu redução nos níveis transcricionais deste gene, enquanto os outros mutantes não apresentaram alterações.

No intuito de avaliar se os genes luxS, qseC e sdiA exercem regulações cruzadas entre si, seus níveis transcricionais foram quantificados nas amostras mutantes (Figura 37). As amostras $\Delta q s e C$ e $\Delta s d i A$ apresentaram níveis superiores à amostra selvagem em relação à transcrição de luxS. Houve incremento da transcrição de qseC na amostra mutante em luxS e diminuição na amostra mutante em sdiA. Os níveis transcricionais de sdiA aumentaram nas amostras $\Delta / u x S$ e $\Delta q s e C$. A amostra duplo mutante apresentou o maior nível de transcrição de sdiA. 


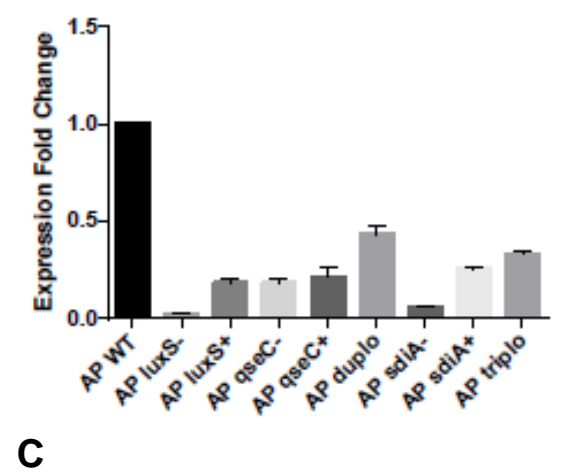

B
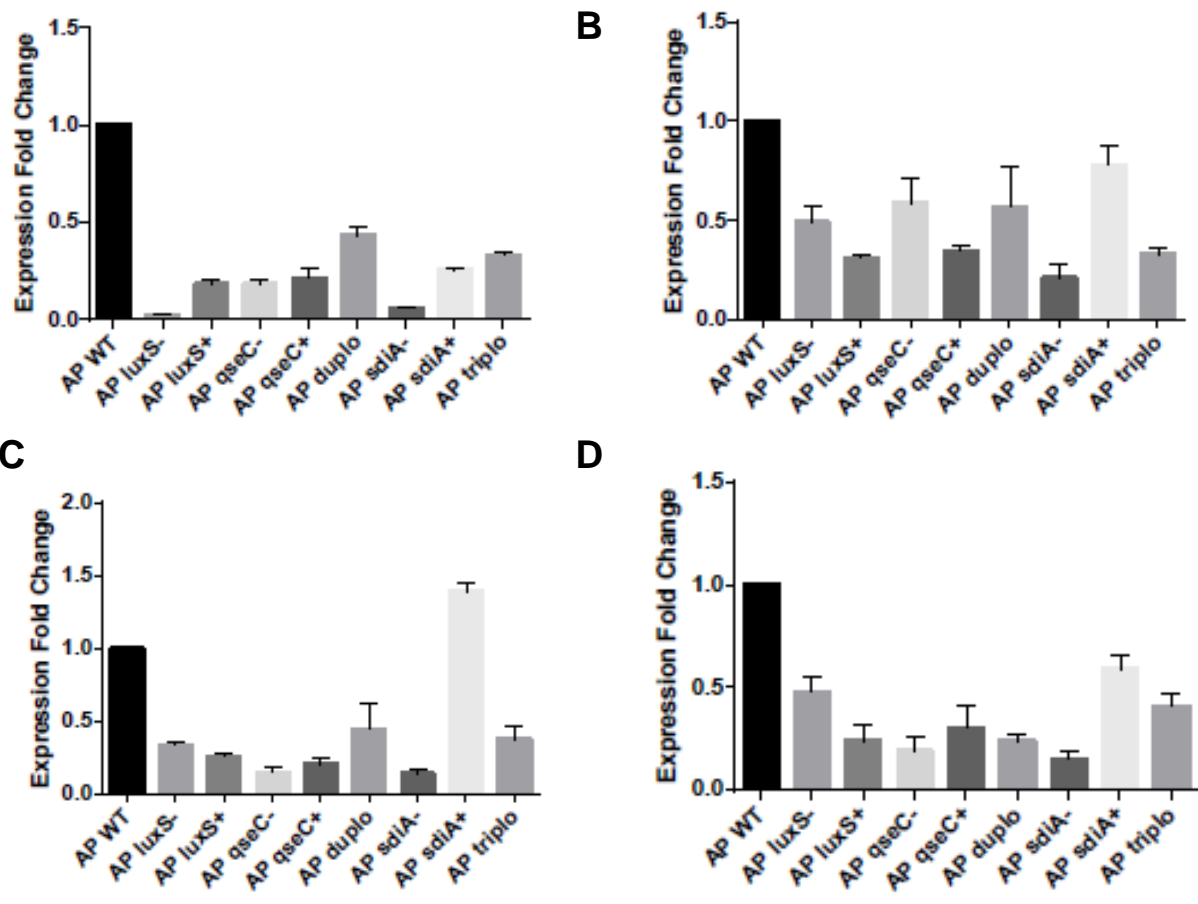

D

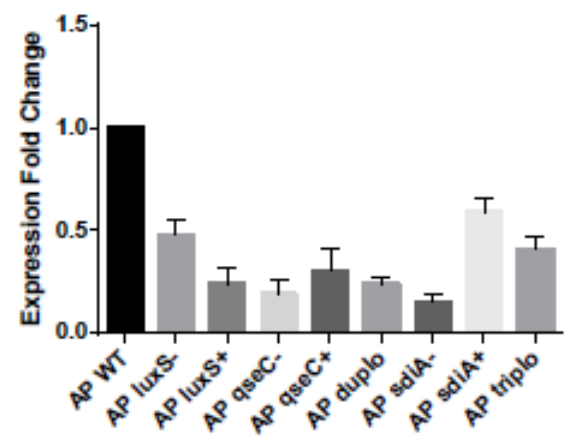

Figura 35 - Análise transcricional dos principais genes envolvidos na formação de biofilme. (A) flic, (B) $b \operatorname{cs} A,(\mathbf{C}) \operatorname{csg} D$ e (D) $\operatorname{csg} A$. Os valores correspondem à média de três triplicatas, mais ou menos o desvio padrão $(p<0,05)$.

A
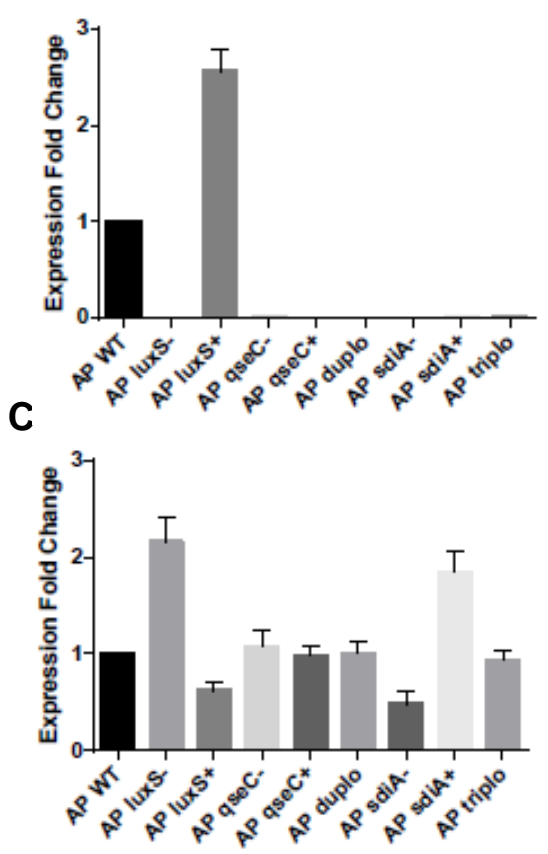

B
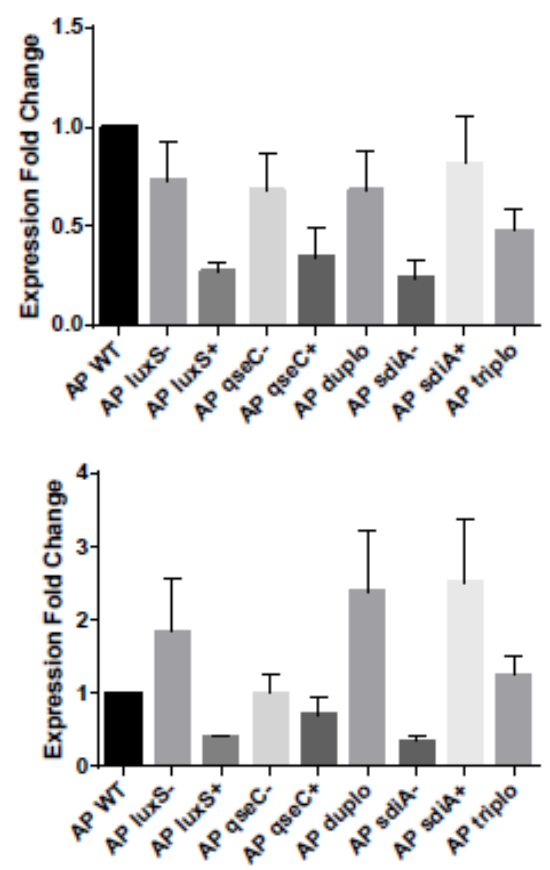

Figura 36 - Análise transcricional dos principais genes envolvidos na formação da lesão $\mathrm{A} / \mathrm{E}$. (A) fimA, (B) ler, (C) eae e (D) espA. Os valores correspondem à média de três triplicatas, mais ou menos o desvio padrão $(p<0,05)$. 
A

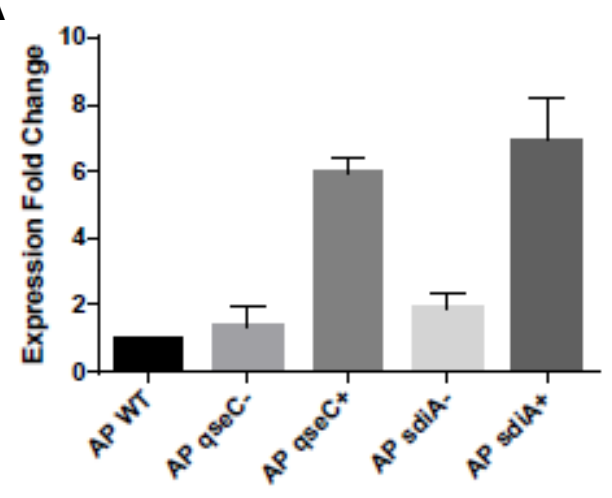

B

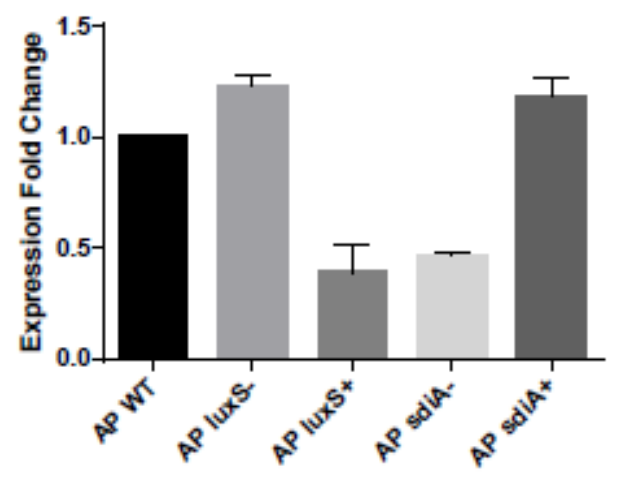

C

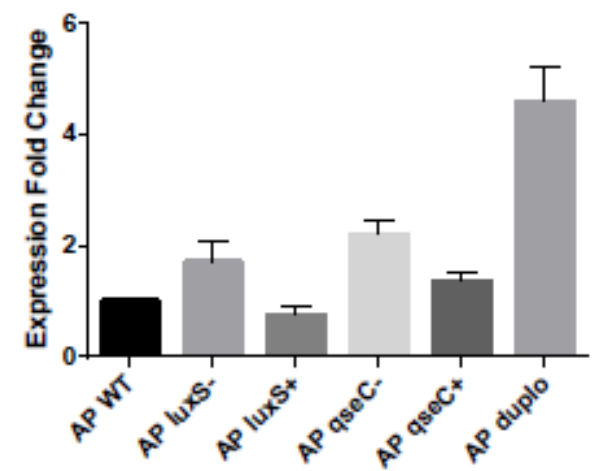

Figura 37 - Análise transcricional dos principais genes envolvidos na regulação por Quorum Sensing em E. coli. (A) luxS, (B) qseC e (C) sdiA. Os valores correspondem à média de três triplicatas, mais ou menos o desvio padrão $(p<0,05)$. 


\section{DISCUSSÃO}

O estudo dos mecanismos que governam os sistemas de Quorum Sensing de uma bactéria patogênica se faz necessário para entender as vias de comunicação utilizadas pelo patógeno. Esta comunicação auxilia na infecção do hospedeiro e na adaptação a novos ambientes, aumentando sua chance de sobrevivência e transmissão para um novo nicho. É comum encontrar mais de um sistema de Quorum Sensing funcional em uma espécie bacteriana, que utilizam mais de um Al para realizar a regulação de múltiplas características que devem ser controladas e moduladas simultaneamente.

A utilização de diversos sistemas de Quorum Sensing permite a integração de uma miríade de sinais de informação, conferindo uma plasticidade para a rede genética. Como toda rede regulatória, sistemas de Quorum Sensing apresentam uma escala hierárquica em que um sistema prioritário deve responder a um sinal, conferindo uma resposta que oferecerá benefícios à célula bacteriana. As hierarquias podem ser formadas em série ou paralelamente. A primeira forma permite que a regulação de genes seja feita de forma temporal definida. A outra atua em certos grupos de genes ou na convergência para a regulação dos mesmos genes (TAGA, BASSLER, 2003). Na maioria dos organismos em que a regulação por Quorum Sensing foi estudada, foi constatado que diversas moléculas sinalizadoras interagem de forma cruzada umas com as outras, de maneira sinérgica ou antagonista (DUNNY, LEONARD, 1997; LAZAZZERA, 2000). A utilização de amostras mutantes em genes relacionados a sistemas de Quorum Sensing, principalmente de amostras com deleções em mais de um sistema, deve ajudar a elucidar a hierarquia e importância deste sistema em fatores de virulência como motilidade, interação com células epiteliais e formação de biofilme.

A amostra de EPEC atípica de sorotipo O111:H25 (AP155) isolada de fezes de cão foi utilizada neste estudo como modelo bacteriano para investigar os efeitos do Quorum Sensing nos fatores de virulência envolvidos em sua patogênese e na adaptação para sobrevivência. Foram utilizadas amostras deletadas nos genes luxS, qseC e sdiA, através de recombinação homóloga mediada pelo Sistema $\lambda$ Red (DATSENKO, WANNER, 2000). A deleção dos genes luxS e qseC deve, em teoria, privar a bactéria de seus sistemas de Quorum Sensing, pela ausência da produção de Al-2 e pela falta do receptor para AI-3, epinefrina e norepinefrina. Apesar da 
incapacidade de E. coli sintetizar Al-1, a amostra mutante no gene sdiA foi gerada com o intuito de verificar se algum fenótipo demonstraria diferenças em relação à amostra selvagem, podendo indicar uma função ainda não descrita para SdiA neste patótipo. A amostra duplo mutante foi utilizada no sentido de verificar a atividade de uma bactéria carente em dois sistemas de Quorum Sensing, e a amostra triplo mutante representa uma bactéria desprovida de todos os sistemas de Quorum Sensing conhecidos nesta espécie.

A geração de amostras mutantes pode ocasionar perturbações metabólicas inesperadas, que podem mascarar outros fenótipos e alterar a taxa de crescimento bacteriano. Devido a este problema, curvas de crescimento bacteriano foram analisadas a fim de verificar se as deleções dos genes dos sistemas de Quorum Sensing afetariam o metabolismo celular, prejudicando a interpretação de outros fenótipos. Tanto amostras mutantes quanto complementadas não demonstraram diferenças no crescimento quando comparadas a amostras selvagens, confirmando que as mutações isogênicas não afetaram o crescimento bacteriano.

A motilidade bacteriana é um mecanismo celular que envolve a síntese e expressão do flagelo, uma estrutura extracelular que responde por quimiotaxia de moléculas atrativas ou repulsivas, temperatura, osmolaridade e moléculas sinalizadoras integrantes dos sistemas de Quorum Sensing. A expressão de flagelo está sob controle de um complexo regulon, com mais de 50 genes organizados em pelo menos 17 operons (CHILCOTT, HUGHES, 2005). O promotor flhDC codifica o regulador global de flagelo e motilidade e é responsável pela ativação de genes envolvidos na produção do fator sigma FliA ( $\sigma 28)$, entre outros. FliA é necessário para a RNA polimerase reconhecer o promotor dos genes flagelares e iniciar transcrição de proteínas relacionadas à motilidade (CHILCOTT, HUGHES, 2005). Os ensaios de motilidade realizados neste estudo indicam que luxS regula de forma positiva este fenótipo, evidenciado pela diminuição da motilidade em amostras mutantes em luxS. Confirmando este resultado, os níveis de transcrição do gene fliC diminuíram no mutante em luxS em comparação aos níveis encontrados na amostra selvagem.

Resultados similares foram obtidos por Sircili e colaboradores (2004) e por Haigh e colaboradores (2013) em ensaios com tEPEC E2348/69 mutante em luxS. Sperandio e colaboradores (2001), utilizando como modelo experimental uma amostra de EHEC, também puderam constatar a redução da atividade flagelar em 
mutantes luxS que exibiram diminuição na transcrição de flhDC. De maneira inversa, Ling e colaboradores (2010) observaram aumento da motilidade flagelar em amostra de E.coli K-12 mutante em luxS, com aumento da transcrição de flhDC. Os autores deste estudo levantaram a hipótese de que este incremento na motilidade pode estar relacionado a uma diminuição dos níveis de c-di-GMP, um mensageiro secundário importante na formação de biofilme. Krin e colaboradores (2006) relataram um efeito inibitório de LuxS na motilidade de Photorhabdus luminescens, enquanto outros autores não observaram efeitos de LuxS neste fenótipo em Listeria monocytogenes, Proteus mirabilis e V. vulnificus (SCHNEIDER et al., 2002; BELVAL et al., 2006; KIM et al., 2006).

A adição de Al-2 exógeno aumentou a motilidade do mutante em luxS a níveis similares à amostra selvagem, indicando uma restauração do fenótipo. $A$ presença de Al-2 exógeno no meio aumentou a motilidade de todas as amostras utilizadas neste estudo. González-Barrios e colaboradores (2006) também observaram aumento de motilidade em E. coli ATCC 25404 e MG1655 após a adição de Al-2 ao meio de cultura. Os autores relataram aumento da transcrição de qseB, que por sua vez aumenta a transcrição de $f l h D$, fliA, fliC e motA. O papel de Al-2 como um quimioatraente também foi descrito por Laganenka e colaboradores (2016), promovendo autoagregação entre células bacterianas em baixa densidade celular. Em E. coli comensal entérica, Al-2 funciona como um atraente, e em $H$. pylori funciona como repelente (ANDERSON et al., 2015).

O gene qse $C$ também demonstrou ter algum papel na motilidade da amostra de estudo, e a temperatura de crescimento parece afetar este fenótipo na ausência de qseC. Quando incubado a $37^{\circ} \mathrm{C}$, a motilidade do mutante em qseC aumentou em relação a amostra selvagem, enquanto o crescimento a $26^{\circ} \mathrm{C}$ indicou uma influência negativa na motilidade na ausência de qseC. A adição de epinefrina ao meio de cultura resultou em aumento da motilidade de todas as amostras, inclusive daquelas com deleção em qseC. É possível que isto tenha sido observado pela presença de QseE, outro sensor de epinefrina na célula bacteriana (CLARKE et al., 2006; READING et al., 2009). Bansal e colaboradores (2007) constataram que epinefrina atua como um composto atrativo em EHEC, aumentando a motilidade da amostra estudada.

A função de QseC na motilidade bacteriana já foi descrita por outros autores. Bearson e Bearson (2008) avaliaram uma amostra de S. typhimurium mutante em 
qseC que apresentou motilidade diminuída. Esta regulação negativa da motilidade em mutantes em qseC também foi observada em amostras de UPEC e EHEC (NJOROGE, SPERANDIO, 2012; GUCKES et al., 2013). Sperandio e colaboradores (2002) demonstraram que EHEC e E. coli K-12 mutantes em qseC tiveram transcrição de genes flagelares de classe 1, 2 e 3 diminuída. No presente trabalho, as análises transcricionais demonstraram menores níveis para fliC no mutante em qseC em comparação a amostra selvagem. $O$ aumento da motilidade sob temperatura de $37^{\circ} \mathrm{C}$ deve superar a baixa transcrição de fliC de alguma maneira. A regulação da motilidade mediada por QseC foi elucidada por Clarke e Sperandio, (2005). Neste trabalho, os autores identificaram sítios do promotor de flhDC como alvo de ligação do regulador de resposta QseB. A proteína QseC contém dois domínios, um domínio histidina quinase e um domínio ATPase. QseC promove a fosforilação de QseB transferindo um grupo fosfato proveniente de autofosforilação, QseB fosforilado por sua vez pode se ligar a duas regiões diferentes do promotor de flhDC. A transcrição de flhDC ocorre em resposta ao processo coordenado dependente da intensidade de sinal recebido por QseC. Se o sinal é baixo, QseB se liga de forma a reprimir a expressão do flagelo. Quando o sinal recebido por QseC é alto, QseB fosforilado se liga a regiões do promotor de $f l h D C$, ativando a expressão de flagelo. Esta ligação de QseB pode expor o promotor de fliA, permitindo que a RNA polimerase interaja com FliA dando início a transcrição de flhDC (CLARKE, SPERANDIO, 2005)

Os efeitos observados no presente trabalho e por diversos autores em relação à ausência de QseC parecem estar ligados ao estado de fosforilação de QseB. Kostakioti e colaboradores (2009) relataram a repressão da transcrição de genes devido a ação de QseB constantemente fosforilado. Em UPEC, a proteína sensora PmrB (polimixin resistant) é o doador de fosfato para QseB na ausência de QseC (GUCKES et al., 2013). Embora ocorra a fosforilação do regulador de resposta por uma proteína sensora não cognata, sua desfosforilação por proteína sensora não cognata é um evento raro e desfavorável (SIRYAPORN, GOULIAN, 2008). Deste modo, QseB pode se ligar diretamente a promotores de genes-alvo reprimindo a transcrição ou indiretamente pela regulação positiva de repressores destes genesalvo. Uma regulação correta exercida por QseB necessita da ação fosfatase empregada pelo domínio ATPase de QseC. Deste modo, QseC recebe sinais de acordo com a necessidade fisiológica da célula, e a maneira que transmite os sinais 
que sente é pela fosforilação de QseB e pela remoção do grupo fosfato. É possível que a deleção de $q s e C$ na amostra $\triangle q s e C$ resulte na ação direta ou indireta de QseB ativando a motilidade a $37^{\circ} \mathrm{C}$ e reprimindo-a a $26^{\circ} \mathrm{C}$.

Os sistemas de Quorum Sensing envolvendo Al-2 e Al-3 tem um papel na motilidade bacteriana, e as vias que atuam nestas regulações devem ser empregadas de acordo com a condição ambiental em que a bactéria está inserida. Os resultados obtidos com a amostra duplo mutante indicam a possibilidade de uma interação antagônica entre os genes qseC e luxS, visto que a motilidade desta amostra quando crescida a $26{ }^{\circ} \mathrm{C}$ foi similar à observada na amostra mutante em luxS, e quando crescida a $37{ }^{\circ} \mathrm{C}$ foi similar à amostra mutante em qseC. Interessantemente, a amostra duplo mutante apresentou a menor redução da transcrição de fliC entre as amostras mutantes.

Gonzalez-Barrios e colaboradores (2006) caracterizaram a proteína reguladora MqsR (motility quorum sensing regulator) como um mediador global da sinalização por Al-2 em E. coli. Em estudos feitos com amostras de E. coli K-12 foi relatado que Al-2 é reconhecido por MqsR, e este por sua vez regula positivamente de forma direta ou indireta $Q s e B$, promovendo ativação dos genes do operon flhDC. Como visto no presente trabalho, a adição de Al-2 exógeno aumentou a motilidade da amostra duplo e triplo mutantes, provavelmente via MqsR.

A variação na motilidade vista no duplo mutante em duas temperaturas estudadas possivelmente indica que a $26{ }^{\circ} \mathrm{C}$ a bactéria sofra maior influência na ativação do flagelo por QseB pela sinalização via Al-2. Se o crescimento bacteriano ocorre sob temperatura de $37^{\circ} \mathrm{C}$, QseB deve sofrer maior influência pela ação de seu sensor histidina quinase cognato QseC. A regulação coordenada da transcrição de fIhDC por diversos fatores celulares permite que a célula faça um controle preciso do gasto energético necessário para a montagem do flagelo (CLARKE, SPERANDIO, 2005).

A deleção de sdiA na amostra $\Delta$ sdiA demonstrou um papel positivo para este gene na motilidade em temperatura de $26^{\circ} \mathrm{C}$, indicado pelo halo de menor diâmetro formado por esta amostra em comparação à amostra selvagem. De maneira inversa, a $37^{\circ} \mathrm{C}$ houve um ligeiro aumento na motilidade, porém não significativo quando comparado à amostra selvagem. Lee e colaboradores (2007) e Culler e colaboradores (2018) obtiveram resultados similares ao analisar o aumento da motilidade em uma amostra de E. coli mutante em sdiA. No presente trabalho, a 
adição de Al-1 exógeno resultou em aumento da motilidade de todas as amostras. É possível que o Al-1 adicionado seja detectado por outro sensor na bactéria e estimule a atividade flagelar, visto que houve aumento de motilidade mesmo em bactérias deletadas em sdiA. O mutante triplo não apresentou diferença na motilidade em comparação à amostra selvagem em ambas as temperaturas testadas. A falta de sistemas de Quorum Sensing nesta amostra, inclusive a falta de interação cruzada entre os diferentes sistemas pode ter deixado a célula incapaz de responder aos sinais recebidos e controlados por Quorum Sensing.

A produção de biofilme é um processo comum e essencial para a vida microbiana. A vida em comunidade proporciona diversas vantagens adaptativas e competitivas. O nosso entendimento sobre o desenvolvimento, estrutura e funcionalidade do biofilme ainda é muito limitado, pois apenas recentemente o conceito de vida em comunidade em organismos unicelulares foi aceito. Utilizando abordagens que incluem a quantificação e a visualização da estrutura do biofilme através de microscopia confocal por laser, além da avaliação da produção de componentes da matriz extracelular, pudemos inferir a influência de sistemas de Quorum Sensing neste processo.

De um modo geral, as amostras apresentaram maior formação de biofilme quando crescidas a $26^{\circ} \mathrm{C}$ do que a $37^{\circ} \mathrm{C}$. A amostra selvagem formou um denso biofilme quando crescida a $26^{\circ} \mathrm{C}$, mas sua produção foi praticamente reprimida sob temperatura de $37^{\circ} \mathrm{C}$. Estes resultados corroboram com os encontrados por WeissMuskat e colaboradores (2010), que demonstraram uma grande capacidade de formação de biofilme em superfície abiótica por uma amostra de aEPEC do sorotipo 055:H7 apenas a $26^{\circ} \mathrm{C}$. A expressão de fímbria curli foi identificada como um processo importante para a obtenção desta vigorosa formação de biofilme. A produção desta estrutura mediante temperatura de crescimento já foi relatada por Bokranz e colaboradores (2005). Esses autores observaram que UPEC tipicamente expressa curli e celulose a $28{ }^{\circ} \mathrm{C}$, mas não a $37^{\circ} \mathrm{C}$, enquanto $E$. coli comensal expressa estas estruturas em ambas temperaturas. Ólsen e colaboradores (1989) descreveram a expressão ótima para fímbria curli em temperaturas abaixo de $30{ }^{\circ} \mathrm{C}$, sob baixa nutrição e osmolaridade, e durante a fase estacionária. Estas condições geralmente são encontradas por $E$. coli fora do hospedeiro, quando o crescimento e sobrevivência podem ser facilitados pela habilidade bacteriana de formar biofilme (PRIGENT-COMBARET et al., 2000). De fato, de acordo com os experimentos de 
expressão de fímbria curli em meio Vermelho Congo obtidos no presente trabalho, as amostras apresentaram maior produção desta estrutura a $26 \stackrel{\circ}{ } \mathrm{C}$.

A expressão de fímbria curli pela amostra mutante em qseC pode ter influenciado a sua capacidade de formação de biofilme. Sob temperatura de $26{ }^{\circ} \mathrm{C}$, houve uma redução significativa no biofilme formado por $\Delta q s e C$ em comparação à amostra selvagem, com perceptiva diminuição da expressão de fímbria curli e menor formação de biofilme em lamínula de vidro como visto em microscopia confocal. Os ensaios de formação de biofilme realizados sob temperatura de $37^{\circ} \mathrm{C}$ demonstraram aumento na formação de biofilme tanto em placa de poliestireno como em lamínula de vidro e uma repressão pronunciada da expressão de curli foi observada nesta temperatura de crescimento. Estes resultados indicam que o gene qseC e curli desempenham um papel negativo na formação de biofilme a $37^{\circ} \mathrm{C}$, e positivo a $26 \stackrel{\circ}{\circ}$. Hadjifrangiskou e colaboradores (2011) demonstraram que a deleção de qseC cessa a expressão de fímbria curli pelo aumento de RstA, repressor do regulador global de curli, CsgD. Também observamos que a transcrição dos genes $\operatorname{csg} D$ e $\operatorname{csg} A$ foi reduzida na amostra mutante em $q s e C$, podendo ser o motivo da falta de expressão de curli em ensaio Vermelho Congo.

A repressão de fímbria curli na falta de QseC também pode ser influenciada direta ou indiretamente pela ação de QseB constantemente fosforilado, visto que um mutante em QseB exibe expressão de fímbria curli parecida com a amostra selvagem (KOSTAKIOTI et al., 2009). A regulação da formação de biofilme pela epinefrina adicionada ao meio de cultura resultou em leve redução desta estrutura nas amostras selvagem e $\Delta q s e C^{+}$. Amostras com mutação em qseC sofreram pouca redução na formação de biofilme, provavelmente como um resultado da interação de QseE com epinefrina. A análise por microscopia confocal também indicou um efeito negativo pela adição de epinefrina em todas as amostras, sendo mais pronunciado após incubação em temperatura de $37^{\circ} \mathrm{C}$. Como observado no ensaio de formação de biofilme em placas de poliestireno, o gene qse $C$ exerce um papel negativo neste fenótipo nesta temperatura, e a interação entre este receptor e epinefrina deve reduzir o biofilme produzido pela amostra de estudo. Algo similar deve ocorrer na interação de epinefrina e o receptor QseE, devido ao efeito negativo do hormônio mesmo em amostras mutantes em qseC.

O biofilme formado pela amostra mutante em luxS aumentou em ambas as temperaturas testadas quando comparado com a amostra selvagem. A formação de 
microcolônias é uma etapa inicial na formação de biofilmes, e em EPEC, é mediada por diversas adesinas, incluindo Bfp e EspA (MOREIRA et al., 2006). O aumento da transcrição do gene espA na amostra mutante em luxS pode ter influenciado o incremento da formação de biofilme. A visualização da formação de biofilme da amostra $\Delta l u x S$ por microscopia confocal diferiu da quantificação em placa de poliestireno apenas para a temperatura de $37^{\circ} \mathrm{C}$, na qual foi observada a diminuição do biofilme em comparação à amostra selvagem. É possível que a mudança da superfície de adesão possa ter influenciado este resultado.

No ensaio com Vermelho Congo, a produção de fímbria curli pela amostra $\Delta$ luxS não demonstrou diferença em relação a amostra selvagem. Ambas as amostras foram capazes de expressar esta estrutura. No entanto, a transcrição dos genes $\operatorname{csg} D$ e $\operatorname{csg} A$ diminuiu na amostra mutante em luxS. González-Barrios e colaboradores (2006) observaram que MqsR induz a expressão de fímbria curli pelo aumento da transcrição de crl. Por MqsR ter sido relatado como um mediador da sinalização por Al-2 em processos celulares em $E$. coli, a falta deste sinal no mutante em luxS pode ter causado a diminuição da transcrição de curli de forma MqsR dependente. É possível que mesmo com a diminuição da transcrição de genes relacionados à curli, a amostra $\Delta / u x S$ seja capaz de expressar esta estrutura.

O aumento de biofilme em amostras mutantes em luxS também foi relatado nas espécies $H$. pylori, $L$. monocytogenes, Staphylococcus epidermidis e Streptococcus gordonii (BLEHERT et al., 2003; COLE et al., 2004; SELA et al., 2006; $\mathrm{XU}$ et al., 2006). Porém, resultados contraditórios também foram encontrados na literatura. González-Barrios e colaboradores (2006), em um ensaio de formação de biofilme em meio LB utilizando $E$. coli K-12 mutante em luxS, verificaram redução desta estrutura. Neste mesmo trabalho os autores relacionaram a baixa formação de biofilme com expressão ativa de flagelo. Amostras de S. typhimurium, B. subtilis, $C$. jejuni e K. pneumoniae mutantes em luxS também demonstraram menor formação de biofilme (BALESTRINO et al., 2005; De KEERSMAECKER et al., 2005; LOMBARDIA et al., 2006; REESER et al., 2007).

Anderson e colaboradores (2015) relataram diminuição na formação de biofilme pela adição de Al-2 no meio de cultura em experimentos utilizando como modelo a bactéria $H$. pylori, observando um número maior de células planctônicas na presença deste composto. Estes autores propuseram Al-2 como uma molécula quimioatrativa que estimula a dispersão de bactérias em biofilmes estabelecidos. 
Laganenka e colaboradores (2016) observaram redução da agregação bacteriana após a adição de DPD/AI-2 sintético em uma monocultura de E. coli. Pelos resultados observados em ensaios de motilidade no presente trabalho, é possível relacionar a mesma função para a sinalização por AI-2, pois na ausência deste sinal há diminuição da motilidade bacteriana e aumento significativo da formação de biofilme. De maneira inversa, com a adição de Al-2 exógeno, foi possível observar diminuição da produção de biofilme em todas as amostras testadas e aumento da motilidade.

O Al-2 exógeno adicionado diminuiu a quantidade de biofilme formado em placa de poliestireno e resultou em microcolônias mais esparsas e de menor espessura de acordo com a visualização por microscopia confocal. A maturação do biofilme em $E$. coli está relacionada com a repressão de genes envolvidos com motilidade e com a produção de ácido colânico (DANESE et al., 2000). Pode-se especular que a amostra mutante em luxS simule uma bactéria no processo de maturação de biofilme. Al-2 pode servir como um quimioatraente em baixa densidade populacional, realizando co-agregação entre células individuais móveis, aumentando a densidade local e, em seguida, ocorrendo adesão à superfície e formação de biofilme. À medida que a densidade populacional aumenta, consequentemente elevando os níveis de Al-2, a sinalização por essa molécula serve como dispersivo em um biofilme maduro.

Em ambas as temperaturas testadas, a amostra duplo mutante demonstrou características fenotípicas similares à $\Delta q s e C$ de acordo com a quantificação de biofilme em placa de poliestireno e microscopia confocal. Isto pode indicar a existência de uma escala hierárquica na regulação da formação de biofilme por Quorum Sensing, tendo qseC uma posição superior a luxS neste fenótipo. A falta de expressão de curli também foi identificada pela amostra duplo mutante, demonstrando mais uma vez a influência maior de qseC do que luxS.

A amostra mutante em sdiA demonstrou dificuldade na formação de biofilme em ambas as temperaturas testadas, sugerindo uma influência positiva do gene sdiA neste fenótipo. A visualização da estrutura do biofilme por microscopia confocal foi de acordo com o resultado obtido em placa de poliestireno, com exceção ao crescimento realizado em temperatura de $37^{\circ} \mathrm{C}$, em que $\Delta s d i A$ apresentou maior espessura em relação à amostra selvagem. Lee e colaboradores (2007) sugeriram uma regulação negativa exercida por SdiA na formação de biofilme. Os autores 
deste trabalho confirmaram este efeito em uma amostra $E$. coli K-12 mutante em sdiA, que demonstrou maior formação de biofilme em relação à amostra selvagem. Culler e colaboradores (2018) também relataram influência negativa exercida por SdiA na formação de biofilme em amostras de aEPEC mutantes em sdiA.

Smith e colaboradores (2017) observaram que a deleção de sdiA em uma amostra de E. coli BW25113 causa superprodução de curli em meio Vermelho Congo. Shankar e colaboradores (2012) relataram aumento da expressão de $\operatorname{csgBAC}$ e da produção de curli em uma amostra de Enterobacter com deleção em sdiA. A maior produção de biofilme também foi relacionada com o aumento de expressão de curli nesta amostra (SHANKAR et al., 2012). Segundo os autores deste estudo, o aumento de expressão de curli ocorreu pelo "alívio" da repressão de $\operatorname{csgBAC}$ exercido por SdiA. Ao contrário disso, no presente trabalho, a amostra AP155 $\Delta s d i A$ apresentou diminuição da transcrição dos genes $\operatorname{csg} A$ e $\operatorname{csg} D$, o que pode estar relacionado com a redução da formação de biofilme por esta amostra. Apesar da baixa transcrição destes genes, a amostra mutante em sdiA foi capaz de expressar curli em meio Vermelho Congo.

A adição de Al-1 exógeno ao meio de cultura resultou em redução da formação de biofilme pelas amostras selvagem e complementada em sdiA, e isto pode ser atribuído à presença de SdiA, visto que amostras deletadas neste gene ( $\Delta s d i A$ e triplo mutante) não apresentaram biofilme alterado na presença deste composto. A temperatura parece influenciar o reconhecimento de Al-1 por SdiA, devido a uma maior redução de biofilme sob crescimento a $26{ }^{\circ} \mathrm{C}$. A diminuição da formação de biofilme por AHL também foi descrita por Culler e colaboradores (2018) e Lee e colaboradores (2007). Van Houdt e colaboradores (2006) relataram anteriormente que SdiA integra estímulos externos à sua resposta, incluindo temperatura e $\mathrm{pH}$. Estes autores observaram maior reatividade de SdiA à $\mathrm{AHL}$ apenas em temperaturas mais baixas $\left(30^{\circ} \mathrm{C}\right)$ e não a $37^{\circ} \mathrm{C}$.

A observação da formação de biofilme por microscopia confocal na presença de Al-1 demonstrou resultados conflitantes com os obtidos em placa de poliestireno. A formação de biofilme das amostras selvagem e $\Delta s d i A^{+}$aumentou após adição de $\mathrm{AHL}$ ao meio. Como SdiA responde à estímulos ambientais, a mudança da superfície de adesão (plástico para vidro) pode ter influenciado a diferença na formação de biofilme. É ainda possível que SdiA seja capaz de interagir com outro composto que não seja $\mathrm{AHL}$, exercendo uma influência positiva na formação de 
biofilme na amostra AP155. Outros autores já relataram a atividade de SdiA em $E$. coli mesmo na ausência de AHL (DYSZEL et al., 2010; HUGHES et al., 2010; SPERANDIO, 2010). Os resultados conflitantes entre o presente trabalho e os encontrados na literatura ilustram a grande heterogeneidade entre amostras de $E$. coli, inclusive de amostras pertencentes ao mesmo patótipo como aEPEC.

A formação de biofilme pela amostra mutante triplo gerou resultados interessantes. Diferente da amostra $\Delta q s e C, \Delta s d i A$ e duplo mutante, e mais parecida a amostra $\Delta / u x S$, a deleção nos três genes relacionados a Quorum Sensing teve uma influência positiva neste fenótipo. A amostra $\Delta q s e C / \Delta / u x S / \Delta s d i A$ apresentou a maior formação de biofilme entre todas avaliadas, tanto em placa de poliestireno como em lamínula de vidro. Esta amostra também não demonstrou expressão de fímbria curli em meio Vermelho Congo, apresentando baixos níveis transcricionais dos genes $\operatorname{csg} D$ e $\operatorname{csg} A$. É possível que com a falta de sistemas de comunicação a bactéria ative processos celulares alternativos, formando um biofilme robusto como resposta à falta de sinalização por Quorum Sensing.

A produção de celulose pelas amostras estudadas foi avaliada sob duas temperaturas de crescimento diferentes em meio contendo Calcofluor. Quando incubadas a $37^{\circ} \mathrm{C}$, todas as amostras foram capazes de produzir celulose. Porém, a $26{ }^{\circ} \mathrm{C}$, apenas a amostra selvagem foi considerada positiva para este fenótipo. Através destes dados, é possível inferir que na temperatura de $26{ }^{\circ} \mathrm{C}$ os genes luxS, qseC e sdiA desempenham algum papel na produção de celulose. Quando o crescimento é realizado em temperatura de $37^{\circ} \mathrm{C}$, a falta destes genes parece ser compensada de outra forma pela célula, corroborado pela produção de celulose em todas as amostras mutantes. A transcrição do gene $b c s A$ sofreu redução em todos os mutantes utilizados neste estudo, podendo ser responsável pelo resultado negativo observado. CsgD também controla a produção de celulose através da transcrição do gene adrA, que está relacionado à formação de matriz extracelular (ROMLING et al., 2000). Como a transcrição de csgD também sofreu redução nas amostras mutantes, este pode ser outro motivo para a falta de produção de celulose sob temperatura de $26^{\circ} \mathrm{C}$. Além de AdrA e CsgD, o operon de bcs também é parcialmente regulado por AdfD, uma fímbria agregativa que aumenta a produção de celulose e curli (MU et al., 2005).

Weiss-Muszkat e colaboradores (2010) relataram a produção de celulose como um processo importante na composição de EPS em amostras de aEPEC. Por 
outro lado, Uhlich e colaboradores (2006) não identificaram celulose como um componente importante na formação de biofilme por EHEC. Estes resultados divergentes demonstram a existência de variações em amostras de $E$. coli geneticamente parecidas. A produção de celulose fora do hospedeiro deve ocorrer sob o controle de uma regulação mais precisa, e os genes relacionados ao Quorum Sensing devem desempenhar algum papel nestas condições. Quando se encontra dentro do hospedeiro, a produção de celulose deve ser regulada por outras vias, e estes genes atuam na regulação de outros processos, como fatores de virulência, necessários para colonização. A temperatura de $26{ }^{\circ} \mathrm{C}$ simularia o ambiente fora do hospedeiro, em que a bactéria deve coordenar seus processos fisiológicos de maneira correta a fim de superar as adversidades a que está submetida.

A adesão da bactéria ao epitélio é um dos primeiros passos para a colonização do hospedeiro, e diversos fatores contribuem para uma colonização bem-sucedida. Os ensaios de interação das amostras de estudo com células epiteliais HeLa demonstraram que a amostra mutante em luxS apresenta um número maior de bactérias aderidas em comparação à amostra selvagem. Este efeito da deleção de luxS pôde ser observado tanto pela visualização de bactérias aderidas à células epiteliais sob microscopia, como pela contagem de UFC após a interação da amostra bacteriana com a cultura celular. Este resultado sugere que a sinalização por AI-2 regula de maneira negativa a adesão bacteriana na amostra AP155. De fato, após a adição de Al-2 exógeno no meio de cultura, pode-se observar redução do número de bactérias aderidas e na contagem de UFC. Diferente do resultado observado no presente estudo, uma amostra de tEPEC (E2348/69) mutante em luxS se demonstrou deficiente em aderir à células epiteliais, formando microcolonias menores do que a amostra selvagem (SIRCILI et al., 2004). Em uma amostra $E$. coli $\mathrm{K}-12$, Al-2 também foi relacionado na regulação da adesão em células HeLa (BANSAL et al., 2008). Bactérias mutantes em luxS reduziram a patogenicidade em coelhos, o que foi associado à redução da adesão à mucosa intestinal, demonstrando que a sinalização por Al-2 pode ter um papel na colonização e patogênese de EPEC (ZHU et al., 2007).

Estudos anteriores sugerem que os genes da região LEE de EPEC são regulados por Quorum Sensing. A deleção do gene luxS causa a diminuição de proteínas secretadas pelo sistema de secreção tipo III, codificado em LEE (SPERANDIO et al., 1999; SIRCILI et al., 2004). No presente trabalho, a análise da 
transcrição dos genes espA e eae (intimina), ambos codificados em LEE, indicou aumento no número de transcritos após deleção em luxS, apesar da leve diminuição (não significativa) da transcrição de ler, considerado um regulador global de LEE. A transcrição de fimA, uma subunidade estrutural importante para a produção da fímbria tipo 1, foi abolida no mutante em luxS. Este apêndice tem um papel importante na adesão a superfícies bióticas pela ligação em resíduos de manose da célula mamífera pela subunidade FimH (BAORTO et al., 1997). Considerando que os ensaios de adesão foram realizados com a adição de manose no meio de cultura, bloqueando a ligação de $\mathrm{FimH}$, e a transcrição de fimA foi praticamente inexistente, é possível atribuir o aumento da adesão pela amostra $\Delta / u x S$ ao aumento da transcrição de espA e eae. Sharma e colaboradores (2016) relataram anteriormente a importância de espA na adesão de uma amostra EHEC 0157:H7 em células HEp2. A variedade de proteínas expressas na superfície celular de EPEC, como intimina e EspA, provavelmente fornecem uma estratégia de colonização versátil por EPEC, permitindo que se ligue ao enterócito do hospedeiro sob diferentes condições (HUMPHRIES, ARMSTRONG, 2010). A amostra $\Delta / \mathrm{l} x S$ apresentou maior capacidade de formar pedestais em comparação à amostra selvagem, como visto no ensaio de FAS. É possível que este resultado tenha sido observado devido ao aumento dos transcritos de espA e eae, genes importantes para o desenvolvimento da lesão A/E. A adição de Al-2 diminuiu a formação de pedestais pelas amostras testadas, mais uma vez indicando um papel negativo da sinalização por Al-2 na adesão bacteriana.

As amostras com deleção em qseC ( $\Delta q s e C, \Delta q s e C / l l u x S, \Delta q s e C / l u x S /$ sdiA), ao contrário da amostra mutante em luxS, tiveram sua capacidade de adesão comprometida, apresentando menos bactérias aderidas e menor contagem de UFC do que a amostra selvagem. A adição de epinefrina ao meio de cultura durante a interação bactéria-célula epitelial resultou em aumento da adesão pela amostra selvagem e amostras com deleção em qseC. Bansal e colaboradores (2007) também relataram aumento da adesão em células epiteliais por EHEC após a adição de epinefrina.

A formação de pedestais foi reduzida em amostras com deleção em qseC, e diversos autores já relataram a ação de QseC na regulação de LEE em níveis transcricionais e pós-transcricionais (HUGHES et al., 2009; NJOROGE et al., 2012; GRUBER, SPERANDIO, 2014). Apesar desse resultado, as análises transcricionais 
de genes relacionados à LEE como eae e espA não apresentaram diferenças significativas na amostra $\triangle q s e C$ e triplo mutante em comparação à amostra selvagem. A amostra duplo mutante apresentou grande aumento nos níveis transcricionais de espA, porém, não deve ter sido suficiente para aumentar sua capacidade de causar lesão A/E. Similaridades entre amostras deletadas em qseC foram observadas na redução de transcritos de ler, o que pode ter influenciado a diminuição da formação de pedestais. Njoroge e Sperandio (2012), trabalhando com uma amostra de EHEC mutante em qseC, também descreveram diminuição da formação de lesão A/E em células HeLa. Parker e colaboradores (2017) também relataram diminuição da transcrição de ler por EHEC mutante em qseC, além de níveis menores para espA. O regulador de resposta KdpE é capaz de ser fosforilado por QseC, atuando na ativação da expressão de ler, se ligando à seu promotor (MCDANIEL et al;. 1995; RASKO et al., 2008; HUGHES et al., 2009; NJOROGE et al., 2012). É possível que a deleção de qseC realize repressão indireta de ler pela falta de fosforilação de KdpE.

A diminuição da formação de pedestais em amostras deletadas em qseC pode ser relacionada à ausência da sinalização por Al-3 e Epinefrina/Norepinefrina, devido ao papel deste sistema de Quorum Sensing na ativação da lesão A/E (SPERANDIO et al., 2001). De acordo com Clarke e Sperandio (2005), epinefrina pode substituir Al-3 para ativar a transcrição de genes em LEE, promovendo a expressão de T3SS e lesão A/E. No presente trabalho, isso pôde ser observado pela adição de epinefrina ao meio de cultura, que resultou em aumento da formação de pedestais tanto por amostras contendo o receptor QseC (selvagem e $\Delta q s e C^{+}$) quanto por amostras deletadas em qseC ( $\triangle q s e C$, duplo e triplo mutantes). É possível que as amostras deletadas em qse $C$ sejam capazes de sentir epinefrina pelo receptor QseE, porém, foi possível notar um maior número de pedestais em amostras contendo ambos receptores deste hormônio. QseE transfere o sinal recebido para seu regulador de resposta cognato, QseF, que por sua vez ativa diretamente a expressão de $g \operatorname{lm} Y$, um sRNA que participa da regulação póstranscricional de LEE (REICHENBACH et al., 2009; GRUBER, SPERANDIO, 2014). A atividade de QseF na ausência de qseC deve resultar na regulação descoordenada de LEE pois QseC também tem influência na ativação de QseF. A regulação de LEE na presença deste hormônio deve ser mais eficaz quando QseC e QseE estão presentes e funcionais na célula bacteriana. A interação de AI-3 e 
epinefrina com mais de um sensor quinase constitui um mecanismo de "timing" para este sistema, uma característica desejável, pois seria ineficiente para o patógeno expressar LEE, T3SS e flagelo simultaneamente.

Não foi possível detectar níveis de transcrição de fimA nas amostras com deleção em qseC. Isso pode ser explicado pela influência que QseC exerce na expressão de fímbria tipo 1. Kostakioti e colaboradores (2012) descreveram capacidade reduzida na formação desta estrutura por um mutante em qseC, resultando em redução da virulência do patótipo estudado. A fímbria curli já foi descrita como um componente que participa da adesão de bactérias às células epiteliais (HUMPHRIES, ARMSTRONG, 2010). A falta de expressão de curli visto em ensaio Vermelho Congo pelas amostras $\Delta q s e C$, duplo e triplo mutantes pode ter influenciado a capacidade de adesão em células HeLa. Como descrito anteriormente, a deleção de qseC interrompe a expressão de curli pelo aumento da transcrição de rstA, um repressor de $\operatorname{csg} D$ (HADJIFRANGISKOU et al., 2011).

A amostra mutante em sdiA sofreu grande redução na adesão à células epiteliais, evidenciado pela visualização em microscopia e pela contagem de UFC. Sharma e colaboradores (2010) relataram anteriormente o aumento na adesão em células HEp-2 por EHEC mutante em sdiA. Os autores deste estudo observaram aumento da transcrição de genes relacionados à LEE (eae, ler, espA), porém, estatisticamente insignificante em relação à amostra selvagem. Estudos anteriores relataram a deficiência de EHEC mutante em sdiA na colonização do TGI de ovinos (DZIVA et al., 2014). A expressão de LEE e o desenvolvimento da lesão A/E são necessários para a colonização de EHEC na junção reto-anal de ovinos (SHENG et al., 2006). Hughes e colaboradores (2010) relataram SdiA como um repressor direto da expressão de LEE e um ativador indireto de gad (glutamato descarboxilase). Gad é um sistema que oferece resistência a altos níveis de acidez e foi previamente demonstrado como essencial para a sobrevivência e colonização de EHEC em ovinos (PRICE et al., 2004).

No presente trabalho, foi possível observar redução da transcrição de genes relacionados à LEE (eae, ler, espA) e à formação de fímbria tipo 1 (fimA) na amostra $\Delta s d i A$, mesmo na ausência de Al-1. O ensaio de FAS indica um papel positivo para sdiA na formação da lesão $\mathrm{A} / \mathrm{E}$, devido à redução de pedestais formados pela amostra mutante em sdiA. É possível que isto tenha ocorrido pela diminuição da transcrição de genes pertencentes à LEE. Quando Al-1 foi adicionado ao meio de 
cultura no ensaio de interação com células HeLa, as amostras selvagem e $\Delta s d i A^{+}$ apresentaram acréscimo na quantidade de bactérias aderidas e na formação de pedestais. As amostras mutante em sdiA e triplo mutante não demonstraram diferenças significativas na presença deste composto. De maneira oposta, Hughes e colaboradores (2010) descreveram a repressão de LEE por AHL via SdiA como um método para impedir a adesão de EHEC em ambientes hostis como o rúmen e conferir tolerância à altos níveis de acidez. Após passagem pelo rúmen, EHEC não entra em contato com grande quantidade de AHL na junção reto-anal, aliviando a repressão de LEE e promovendo adesão. Além disso, Shimada e colaboradores (2014) descreveram SdiA como um repressor da transcrição de fimA na presença de AHL. De maneira similar ao presente trabalho, Kanamaru e colaboradores (2000) não observaram a repressão de LEE na presença de AHL em uma amostra de EPEC. Os resultados apresentados no presente estudo indicam que é possível atribuir um papel na indução da adesão promovido por AHL, provavelmente via SdiA, na amostra AP155.

De maneira geral, os resultados apresentados no presente trabalho indicam que os três sistemas de Quorum Sensing estudados existem paralelamente e convergem para regular diversos fatores de virulência da bactéria. A possibilidade dos sistemas realizarem regulação entre si não pode ser descartada, pois a célula bacteriana deve estar em equilíbrio e ter versatilidade na regulação de seus processos celulares. Após analisar a transcrição dos genes envolvidos em Quorum Sensing nas amostras mutantes, foi possível observar que o gene luxS exerce influência negativa nos genes qse $C$ e sdiA. O gene sdiA influencia negativamente a transcrição do gene luxS, e positivamente qseC. Por outro lado, o gene qse $C$ tem uma influência negativa na transcrição de sdiA e luxS. A regulação negativa que luxS e qseC exercem em sdiA fica mais evidente observando a amostra duplo mutante, que teve um grande acréscimo de transcritos de sdiA. A redundância do controle da virulência por diversos sistemas de Quorum Sensing já foi descrita na bactéria $V$. cholerae, que possui pelo menos três sistemas de sinalização paralelos e fornecem um mecanismo elaborado e sofisticado para a manutenção da patogenicidade (MILLER et al., 2002).

Não obstante, não se pode destacar a existência de posições hierárquicas entre os sistemas de Quorum Sensing. Os ensaios utilizando a amostra duplo mutante indicam que para certos fatores de virulência como formação de biofilme, 
motilidade e adesão a células epiteliais, o gene qseC exerce maior influência do que o gene luxS. Porém, a integração de fatores ambientais como a temperatura pode reverter a hierarquia dos sistemas, como visto na motilidade da amostra duplo mutante sob temperatura de $26^{\circ} \mathrm{C}$, em que luxS parece tomar uma posição superior à qseC. Neste caso, sugere-se que luxS e qseC compõem uma interação antagônica, corroborando com a influência negativa da transcrição que exercem entre si.

Os resultados obtidos com a amostra triplo mutante ilustram como a regulação gênica é intricada e que ainda é preciso um estudo aprofundado dos processos celulares bacterianos. Apesar da dificuldade em aderir a células epiteliais, esta amostra foi capaz de formar o biofilme mais denso entre as amostras estudadas, e sua motilidade foi praticamente inalterada em comparação à amostra selvagem. Estes resultados foram surpreendentes, pois era esperado que uma bactéria desprovida de três sistemas de Quorum Sensing não fosse capaz de desenvolver processos celulares de maneira "normal". É possível atribuir este efeito ao conceito de robustez, definido como uma capacidade do sistema biológico de manter suas funções, independente de perturbações internas ou ambientais. As perturbações internas podem ocorrer, por exemplo, através de mutações deletérias ou por expressão gênica estocástica (KITANO, 2004; KOONIN, WOLF, 2010; FÉLIX, BARKOULAS, 2015). De acordo com a função biológica a ser mantida e o tipo de perturbação, a robustez pode surgir através de diferentes mecanismos moleculares. O organismo pode adquirir versatilidade na sua estratégia de forrageio, buscando fontes de nutrição alternativas (GUIEYSSE, WUERTZ, 2012). A robustez pode ocorrer também pela redundância genética, ou seja, pela ativação de vias regulatórias ou metabólicas alternativas para executar uma determinada tarefa e manter a homeostase da célula (LI et al., 2010; GU et al., 2003). Supõe-se que a produção de biofilme em excesso seja uma forma de se proteger de um ambiente em que não é possível responder a estímulos externos, desta forma a população bacteriana se abriga dentro do EPS do biofilme em uma tentativa de aumentar suas chances de sobrevivência.

Essa rede de sistemas de comunicação é complexa e interconectada, capaz de integrar tanto sinais ambientais como variações de temperatura e $\mathrm{pH}$, e sinais químicos como autoindutores e produtos de metabolismo bacteriano. Desse modo, estabelece um mecanismo de dispositivo "liga-desliga", ativando fatores de 
virulência em momentos oportunos e priorizando a sobrevivência da célula em situações adversas. É possível que determinados sistemas sejam empregados em certos momentos, e a regulação negativa de um sobre o outro, ou mesmo positiva, seja essencial para a bactéria.

Através dos resultados apresentados no presente trabalho, é possível especular um modelo de regulação da colonização pela amostra AP155. Como observado nos ensaios de motilidade e biofilme, a sinalização por Al-2 estimula a ação do motor flagelar e reprime a formação de biofilme. Se AP155 se encontra em um local normalmente habitado por comensais como o cólon e intestino grosso, receberia o sinal Al-2 produzido por estes residentes do trato gastro-intestinal como um aviso de um ambiente já colonizado e saturado. O Al-2 exógeno atua como um quimioatraente em baixa densidade populacional, estimulando a co-agregação de células individuais através de atividade flagelar, aumentando a densidade local e preparando a população local para a colonização de um ambiente adequado. $\mathrm{O}$ intestino delgado, local de colonização por EPEC, provavelmente apresenta uma baixa concentração de Al-2 extracelular por ser praticamente inabitado por bactérias comensais. Esta condição faria com que a expressão de flagelo fosse reprimida, dando lugar a formação de biofilme e adesão a células epiteliais pelo sistema Al2/LuxS. Quando E. coli coloniza uma nova área e a densidade celular local é baixa, há menor expressão de luxS. Deste modo, processos de adesão seriam estimulados, como visto no mutante em luxS. A produção de fímbrias pode facilitar a colonização de superfícies e outros aspectos no início da formação de biofilme por E. coli (PRATT, KOLTER, 1998; OTTOA et al., 1999; MOREIRA et al., 2003). Porém, visto que a transcrição de fimA sofreu grande redução na amostra $\triangle l u x S$, é provável que essa adesão seja realizada pela ativação da região LEE. O sistema Al3/Epinefrina/QseC teria um papel importante reconhecendo os hormônios epinefrina e norepinefrina, contribuindo na ativação de genes contidos em LEE. Quando este equilíbrio é atingido, a infecção por AP155 ocorre, com adesão a células epiteliais e desenvolvimento da lesão A/E. A dose infectante de EPEC já foi descrita como sendo de alta concentração (DONNENBERG et al., 1993; BIEBER et al., 1998). Ao atingir alta densidade, as bactérias começam a responder à sinalização abundante por Al-2, iniciando o processo de dispersão para a colonização de novos nichos. Isto serviria como uma resposta inteligente para evasão do sistema imune do hospedeiro, não sendo vantajoso para o patógeno permanecer em um ambiente já 
saturado e explorado.

O sistema Al-1/SdiA pode ter um papel na colonização do hospedeiro por AP155. Os ensaios realizados neste trabalho indicam em que o receptor SdiA regula fatores de virulência como a formação de biofilme, motilidade e adesão à célula epitelial. Apesar de SdiA ser descrito como um receptor de AHL, é possível que esta proteína seja funcional mesmo na ausência deste composto. A natureza cooperativa da comunicação por Quorum Sensing é suscetível à exploração de organismos que se beneficiam do sinal produzido por um organismo de outra espécie, sem apresentar um gasto metabólico para a produção deste sinal (SANDOZ et al., 2007; DIGGLE et al., 2007; SCHUSTER et al., 2013; POLLITT et al., 2013). A conservação de SdiA por E. coli pode ter sido mantida evolutivamente para explorar organismos produtores de $\mathrm{AHL}$, conferindo uma vantagem competitiva em interações interespecíficas. A atividade de SdiA independente deste sinal pode ter surgido estabelecendo um controle adicional para a regulação da virulência.

Embora o TGI de vertebrados seja um ambiente rico em espécies bacterianas, a detecção de organismos capazes de produzir AHL neste local se demonstrou praticamente inexistente (ERICKSON et al., 2002; JACOBI et al., 2003; SMITH et al., 2008; DYSZEL et al., 2010; EDRINGTON et al., 2009; SPERANDIO, 2010; HUGHES et al., 2010). Uma ressalva feita em relação aos estudos anteriores que visavam à existência de AHLs no intestino seria que estes foram baseados na utilização de amostras repórteres com uma capacidade limitada para a detecção de diferentes tipos de AHL. É possível que com a utilização de metodologias mais sofisticadas seja detectada a presença de alguma molécula de AHL no TGI. Um achado interessante foi de que com a infecção de um patógeno produtor de $A H L$, este Al se torna disponível para utilização por espécies capazes de sentir este sinal (DYSZEL et al., 2010). De acordo com os ensaios realizados no presente estudo, a amostra AP155 é capaz de responder a AHL exógeno, ativando adesão, lesão A/E e motilidade. Na presença de um patógeno produtor de AHL, AP155 pode sentir o Al e realizar adesão, explorando um nicho vulnerável. Outra possibilidade é pela ativação do flagelo em busca de um ambiente não colonizado e com maior disponibilidade de nutrientes.

Um mecanismo de virulência semelhante ao proposto para AP155 já foi descrito para a bactéria $V$. cholerae. Neste patógeno, a formação de biofilme é ativada em baixas concentrações celulares, e inibida em alta densidade. Desta 
maneira, $V$. cholerae permanece aderido ao hospedeiro em baixas concentrações celulares enquanto fatores de virulência são expressos. Em alta concentração celular, a repressão por Quorum Sensing do biofilme e de fatores de virulência facilita a dispersão para o ambiente. Esta estratégia permite que $V$. cholerae possa competir por nutrientes no hospedeiro em baixa concentração de células e otimizar sua habilidade em colonizar outros hospedeiros quando atinge alta densidade celular (NADELL, BASSLER, 2011). Devido à dose infectante ser alta, o hospedeiro serve como um incubador e, quando a quantidade celular é alta o bastante para assegurar uma infecção eficaz em um novo hospedeiro, a população se dispersa.

Nossos resultados reinforçam a idéia de que a formação de biofilme, a motilidade bacteriana e adesão ao epitélio do hospedeiro são fenótipos que devem ser regulados de forma precisa em resposta a sinais recebidos do ambiente, e diversos mecanismos regulatórios estão envolvidos nestes processos, inclusive Quorum Sensing. A grande heterogeneidade das comunidades microbianas naturais, especialmente da microbiota residente, estabelece um ambiente de intensa interatividade. Para continuarem estáveis, estas comunidades devem se adaptar a diversas mudanças no ambiente como: variações de temperatura, $\mathrm{pH}$, nutrientes disponíveis para consumo ou composição dos residentes da comunidade. Para isso, sistemas de comunicação sofisticados como Quorum Sensing surgiram e foram conservados evolutivamente. A possibilidade de avaliar a densidade populacional e seu estado nutricional através de sinais químicos oferece uma grande vantagem competitiva em ambientes adversos ou em ambientes ainda não explorados. Esta rede regulatória de sistemas de comunicação capta sinais externos e os traduz como respostas que tragam benefícios às bactérias.

O relato de que amostras bacterianas mutantes em genes relacionados a sistemas de Quorum Sensing apresentam virulência atenuada levou ao desenvolvimento de estratégias alternativas para o controle de doenças baseado em inibidores de Quorum Sensing (PIRHONEN et al., 1993; PEARSON et al., 2000; GREENBERG, 2003). Diversas moléculas com diferentes modos de ação foram descobertas desde então, atuando como antagonistas para o bloqueio de receptores, inibidores de sintases e ainda enzimas que degradam moléculas Als (GIVSKOV et al., 1996; DONG et al., 2001; HENTZER et al., 2003; LIN et al., 2003; ELIAS, TAWFIK, 2012; O'LOUGHLIN et al., 2013). Levando em conta que grande parte das vias regulatórias controladas por Quorum Sensing são conservadas entre 
diferentes espécies bacterianas, uma terapia única poderia ser direcionada para agir contra diversos patógenos. Mesmo com resultados promissores, alguns obstáculos ainda devem ser contornados para que este conceito de tratamento seja estabelecido de forma bem-sucedida. A falta de funcionalidade em modelos animais, um sistema de delivery eficiente, potencial toxicidade e um espectro de atividade restrito dificultam a aplicação de resultados observados in vitro em relação a testes clínicos. Além disso, levando em conta a interconectividade entre estes sistemas, é necessário evitar que a interferência de um sistema não aumente a patogenicidade da bactéria através da ativação de outro sistema. A ideia de que tratamentos antiQuorum Sensing agem contra a virulência de patógenos, ao contrário de antibacterianos convencionais, introduz a hipótese de que o surgimento de resistência microbiana seria reduzido ou inexistente (ALLEN et al., 2014). Avanços neste sentido ainda são necessários para determinar tratamentos anti-Quorum Sensing como um substituto a tratamentos convencionais baseados em antimicrobianos. De acordo com estimativas do governo Britânico, em aproximadamente 50 anos, mortes causadas por agentes microbianos resistentes poderão chegar a mais de 10 milhões por ano, acarretando em perdas no produto interno bruto (PIB) mundial de até 100 trilhões de dólares (O'NEILL, 2016). É possível que uma combinação das duas abordagens seja um caminho mais viável a se tomar no futuro. 


\section{CONCLUSÕES}

A sinalização por Al-2 e o gene luxS regulam de forma positiva a motilidade bacteriana e de forma negativa a formação de biofilme e adesão (lesão $A / E$ ) a células epiteliais na amostra aEPEC AP155.

A formação de biofilme é influenciada por QseC de diferentes maneiras dependendo da temperatura de crescimento. A expressão dos componentes da matriz extracelular fímbria curli e celulose desempenham um papel importante na formação desta estrutura. Estes mesmos componentes podem ter papel ativo no processo de adesão em células epiteliais via QseC.

O hormônio adrenérgico epinefrina aumenta a motilidade e a adesão (lesão $\mathrm{A} / \mathrm{E}$ ) às células epiteliais in vitro independente de QseC. Epinefrina diminui a formação de biofilme de maneira similar.

O gene sdiA regula positivamente a motilidade, a formação de biofilme e adesão às células epiteliais (lesão $\mathrm{A} / \mathrm{E}$ ). $\mathrm{O}$ composto $\mathrm{N}$-(3-Oxohexanoyl)-DLhomoserina lactona (3o-C6-DL-HSL) aumenta a motilidade independente de SdiA, diminui a formação de biofilme e aumenta adesão às células epiteliais de forma SdiA dependente.

$O$ gene qseC é hierarquicamente superior a luxS, os dois genes parecem interagir antagonicamente e exercer regulação negativa entre si.

A deleção de genes pertencentes aos três sistemas de Quorum Sensing aumenta a produção de biofilme de forma robusta. 


\section{REFERÊNCIAS*}

ABBA, K.; SINFIELD, R.; HART, C. A.; GARNER, P. Pathogens associated with persistent diarrhoea in children in low and middle income countries: systematic review. BMC Infect Dis v. 9, p. 15, 2009.

ABE, C.M.; TRABULSI, L.R.; BLANCO, J.; BLANCO, M.; DAHBI, G.; BLANCO, J. E.; MORA, A.; FRANZOLIN, M.R.; TADDEI, C. R.; MARTINEZ, M. B.; PIAZZA, R. M.; ELIAS, W. P. Virulence features of atypical enteropathogenic Escherichia coli identified by the eae(+) EAFnegative stx(-) genetic profile. Diagn Microbiol Infect Dis v. 64, p. 357-365, 2009.

AHMER, B. M. M. Cell-to-cell signalling in Escherichia coli and Salmonella enterica. Mol Microbiol v. 52, p. 933-945, 2004.

AIDAR, L.; PENTEADO, A. S.; TRABULSI, L. R.; BLANCO, J. E.; BLANCO, M.; BLANCO, J.; PESTANA DE CASTRO, A. F. Subtypes Of Intimin Among Non-Toxigenic Escherichia Coli From Diarrheic Calves In Brazil. Canad J Of Vet Res v. 64, N. 1, p. 15-20, 2000.

AIRES, Margarida de Mello. Fisiologia. In: Fisiologia. 2012.

AKTAN, I.; SPRIGINGS, K. A.; LA RAGIONE, R. M.; FAULKNER, L. M.; PAIBA, G. A.; WOODWARD, M. J. Characterization of attaching-effacing Escherichia coli isolated from animals at slaughter in England and Wales. Vet Microb v. 102, p. 43-53, 2004.

ALBERT, M. J. Epidemiology of enteropathogenic Escherichia coli infection in Bangladesh. Rev Microbiol v. 7, p. 17-20, 1996.

ALBERT, M. J.; FARUQUE, S.M.; FARUQUE, A.S.G.; NEOGI, P.K.B.; ANSARUZZAMAN, M.; BHUIYAN, N.A.; ALAM, K.; AKBAR, M.S. Controlled study of Escherichia coli diarrheal infections in Bangladeshi children. J Clin Microbiol v. 33, p. 973-977, 1995.

ALLEN, R. C.; POPAT, R.; DIGGLE, S. P.; BROWN, S. P. Targeting virulence: can we make evolution-proof drugs? Nat Rev Microbiol v. 12, p. 300-308, 2014.

AMARA, N.; KROM, B. P.; KAUFMANN, G. F.; MEIJLER, M. M. Macromolecular inhibition of quorum sensing: enzymes, antibodies, and beyond. Chem Rev v. 111, p. 195-208, 2011.

ANDERSON, G. G.; MOREAU-MARQUIS, S.; STANTON, B. A.; O'TOOLE, G. A. In vitro analysis of tobramycin-treated Pseudomonas aeruginosa biofilms on cystic fibrosis-derived airway epithelial cells. Infect Immun v. 76, p. 1423-1433, 2008.

ANDERSON, J. K.; HUANG, J. Y.; WREDEN, C.; SWEENEY, E. G.; GOERS, J.; REMINGTON, S. J.; GUILLEMIN, K. Chemorepulsion from the quorum signal autoinducer-2 promotes Helicobacter pylori biofilm dispersal. MBio v. 6, e00379-15, 2015.

ANNOUS, B. A.; FRATAMICO, P. M.; SMITH, J. L. Quorum Sensing in biofilms: why bacteria behave the way they do. J Food Sci v. 74, p. 24-37, 2009.

ANNOUS, B. A.; SAPERS, G. M.; JONES, D. M.; BURKE, A. Improved Recovered Procedure for Evaluation of Sanitizer Efficacy in Disinfecting Contaminated Cantaloupes. $\mathbf{J}$ Food Sci v. 70, p. 242-247, 2005. 
ARAUJO, J. M.; TABARELLI, G. F.; ARANDA, K. R. S.; FABBRICOTI, S. H.; FAGUNDESNETO, U.; MENDES, C. M. F.; SCALETSKY, I. C. A. Typical enteroaggregative and atypical enteropathogenic types of Escherichia coli are the most prevalent diarrhea-associated pathotypes among brazilian children. J Clin Microbiol v. 45, p. 3396-3399, 2007.

ARENAS-HERNÁNDEZ, M. M. P.; MARTÍNEZ-LAGUNA, Y.; TORRES, A. G. Clinical implications of enteroadherent Escherichia coli. Curr Gastroent Rep v. 14, p. 386-394, 2012.

ARNQVIST, A.; OLSÉN, A.; NORMARK, S. oS-dependent growth-phase induction of the csgBA promoter in Escherichia coli can be achieved in vivo by $\sigma 70$ in the absence of the nucleoid-associated protein H-NS. Mol Microbiol v. 13, p. 1021-1032, 1994.

ASSIS, F. E. A.; WOLF, S.; SUREK, M.; TONI, F. D.; SOUZA, E. M.; PEDROSA, F. O.; FARAH, S. M. S. S.; PICHETH, G.; FADEL-PICHETH, C. M. T. Impact of Aeromonas and diarrheagenic Escherichia coli screening in patients with diarrhea in Paraná, Southern Brazil. J Infect Dev Ctries v. 8, p. 1609-1614, 2014.

ATKINSON, S.; WILLIAMS, P. Quorum sensing and social networking in the microbial world. J Royal Soc Interf rsif20090203, 2009.

BACKHED, F.; LEY, R. E.; SONNENBURG, J. L.; PETERSON, D. A.; GORDON, J. I. Hostbacterial mutualism in the human intestine. Science v. 307, p. 1915-1920, 2005.

BALDINI, M. M.; KAPER, J. B.; LEVINE, M. M.; CANDY, D. C.; MOON, H. W. Plasmidmediated adhesion in enteropathogenic Escherichia coli. J Pediatr Gastroenterol Nutr v. 2, p. 534-539, 1983.

BALESTRINO, D.; HAAGENSEN, J. A.; RICH, C.; FORESTIER, C. Characterization of type 2 quorum sensing in Klebsiella pneumoniae and relationship with biofilm formation. $\mathbf{J}$ Bacteriol v. 187, p. 2870-2880, 2005.

BANIN, E.; VASIL, M. L.; GREENBERG, E. P. Iron and Pseudomonas aeruginosa biofilm formation. Proc Natl Acad Sci v. 102, p. 11076-11081, 2005.

BANSAL, T.; JESUDHASAN, P.; PILLAI, S.; WOOD, T.K.; JAYARAMAN, A. Temporal regulation of enterohemorrhagic Escherichia coli virulence mediated by autoinducer-2. Appl Microbiol Biotechnol v. 78, p. 811-819, 2008.

BANSAL, T.; ENGLERT, D.; LEE, J.; HEGDE, M.; WOOD, T. K.; JAYARAMAN, A. Differential effects of epinephrine, norepinephrine, and indole on Escherichia coli O157:H7 chemotaxis, colonization, and gene expression. Infect Immun v. 75, p. 4597-4607, 2007.

BAORTO, D. M.; GAO, Z.; MALAVIYA, R.; DUSTIN, M. L.; VAN DER MERWE, A.; LUBLIN, D. M.; ABRAHAM, S. N. Survival of FimH-expressing enterobacteria in macrophages relies on glycolipid traffic. Nature v. 389, p. 636-639, 1997.

BARRAUD, N.; HASSETT, D. J.; HWANG, S. H.; RICE, S. A.; KJELLEBERG, S.; WEBB, J. S. Involvement of nitric oxide in biofilm dispersal of Pseudomonas aeruginosa. $\mathbf{J}$ Bacteriol v.188, p. 7344-7353, 2006.

BARROS, S. F.; ABE, C. M.; ROCHA, S. P. D.; RUIZ, R. M.; BEUTIN, L.; TRABULSI, L. R.; ELIAS, W. P. Escherichia coli O125ac:H6 encompasses atypical enteropathogenic E. coli spp. that display the aggregative adherence pattern. J Clin Microbiol v. 46, p. 4052-4055, 2008. 
BASSLER, B. L.; LOSICK, R. Bacterially speaking. Cell v. 125, p. 237-246, 2006.

BASSLER, B. L. How bacteria talk to each other: regulation of gene expression by quorum sensing. Curr Opin Microbiol v. 2, p. 582-587, 1999.

BASSLER, B. L.; WRIGHT, M.; SILVERMAN, M. R. Multiple signalling systems controlling expression of luminescence in Vibrio harveyi: sequence and function of genes encoding a second sensory pathway. Mol Microbiol v. 13, 273-286, 1994.

BEARSON, B. L, BEARSON SMD. The role of the QseC quorum-sensing sensor kinase in colonization and norepinephrine-enhanced motility of Salmonella enterica serovar Typhimurium. Microb Pathogen v. 44, p. 271-278, 2008.

BEAUDRY, M.; ZHU, C.; FAIRBROTHER, J. M.; HAREL, J. Genotypic and phenotypic characterization of Escherichia coli isolates from dogs manifesting attaching and effacing lesions. J Clin Microbiol v. 34, p. 144-148, 1996.

BELAS, R. Biofilms, flagella, and mechanosensing of surfaces by bacteria. Trends Microbiol v. 22, p. 517-527, 2014.

BELAS, R. When the swimming gets tough, the tough form a biofilm. Mol Microbiol v. 90, p. $1-5,2013$.

BELOIN, C.; VALLE, J.; LATOUR-LAMBERT, P.; FAURE, P.; KZREMINSKI, M.; BALESTRINO, D.; HAAGENSEN, J.A.; MOLIN, S.; PRENSIER, G.; ARBEILLE, B.; GHIGO, J.M. Global Impact of Mature Biofilm Lifestyle on Escherichia coli K-12 Gene Expression. Mol Microbiol v. 51, p. 659-674, 2004.

BELVAL, S. C.; GAL, L.; MARGIEWES, S.; GARMYN, D.; PIVETEAU, P.; \& GUZZO, J. Assessment of the roles of LuxS, S-ribosyl homocysteine, and autoinducer 2 in cell attachment during biofilm formation by Listeria monocytogenes EGD-e. Appl Environ Microbiol v. 72, p. 2644-2650, 2006.

BENTANCOR, A.; VILTE, D. A.; RUMI, M. V.; CARBONARI, C. C.; CHINEN, I.; LARZABAL, M.; CATALDI, A.; MERCADO, E. C. Characterization of non-Shiga-toxin-producing Escherichia coli 0157 strains isolated from dogs. Rev Argent Microbiol v. 42, p.46-48, 2010.

BERG, R.D. The indigenous gastrointestinal microflora. Trends Microbiol v.4, p. 430-435, 1996.

BIEBER, D.; RAMER, S. W.; WU, C. Y.; MURRAY, W. J.; TOBE, T.; FERNANDEZ, R.; SCHOOLNIK, G. K. Type IV pili, transient bacterial aggregates, and virulence of enteropathogenic Escherichia coli. Science v. 280, p. 2114-2118, 1998.

BLEHERT, D. S.; PALMER, R. J.; XAVIER, J. B.; ALMEIDA, J. S.; KOLENBRANDER, P. E. Autoinducer 2 production by Streptococcus gordonii DL1 and the biofilm phenotype of a luxS mutant are influenced by nutritional conditions. J Bacteriol v. 185, p. 4851-4860, 2003.

BOEHM, A.; KAISER, M.; LI, H.; SPANGLER, C.; KASPER, C. A.; ACKERMANN, M.; KAEVER, V.; SOURJIK, V.; ROTH, V.; JENAL, U. Second messenger-mediated adjustment of bacterial swimming velocity. Cell v. 141, p. 107-116, 2010.

BOKRANZ, W.; WANG, X.; TSCHAPE, H.; ROMLING, U. Expression of cellulose and curli fimbriae by Escherichia coli isolated from the gastrointestinal tract. $\mathbf{J}$ Med Microbiol v. 54, p. 1171-1182, 2005. 
BORTOLINI, M.R.; TRABULSI, L.R.; KELLER, R.; FRANKEL, G.; SPERANDIO, V. Lack of expression of bundle-forming pili in some clinical isolates of enteropathogenic Escherichia coli (EPEC) is due to a conserved large deletion in the bfp operon. FEMS Microbiol Lett $v$. 179, p. 169-174, 1999.

BOYD, A.; CHAKRABARTY, A. M. Role of alginate lyase in cell detachment of Pseudomonas aeruginosa. Appl Environ Microbiol v. 60, p. 2355-2359, 1994.

BRAY, J. Strains of Bact. coli. Br Med J v. 2, p. 386, 1949.

BRAY, J. Isolation of antigenically homogeneous strains of Bact. coli neapolitanum from summer diarrhea of infants. J Pathol Bacteriol v. 57, p. 239-247, 1945.

BRITO, P. H.; ROCHA, E. P.; XAVIER, K. B.; GORDO, I. Natural genome diversity of Al-2 quorum sensing in Escherichia coli: conserved signal production but labile signal reception. Genome Biol Evol v. 5, p. 16-30, 2012.

BROMBACHER, E.; BARATTO, A.; DOREL, C.; LANDINI, P. Gene Expression Regulation by the Curli Activator CsgD Protein: Modulation of Cellulose Biosynthesis and Control of Negative Determinants for Microbial. Adhes J Bacteriol v.188, p. 2027-2037, 2006.

BUERIS, V.; HUERTA-CANTILLO, J.; NAVARRO-GARCIA, F.; RUIZ, R. M.; CIANCIARULLO, A. M.; ELIAS, W. P. Late establishment of the attaching and effacing lesion caused by atypical enteropathogenic Escherichia coli depends on protein expression regulated by Per. Infect Immun v. 83, p. 379-388, 2015.

BUERIS, V.; SIRCILI, M. P.; TADDEI C. R.; SANTOS, M. F.; FRANZOLIN M. R.; MARTINEZ M. B.; FERRER, S. R.; BARRETO, M. L.; TRABULSI, L. R. Detection of diarrheagenic Escherichia coli from children with and without diarrhea in Salvador, Bahia, Brazil. Mem I Oswaldo Cruz v. 102, p. 839-844, 2007.

BURTON, C. L.; CHHABRA, S. R.; SWIFT, S.; BALDWIN, T. J.; WITHERS, H.; HILL, S. J.; WILLIAMS, P. The growth response of Escherichia coli to neurotransmitters and related catecholamine drugs requires a functional enterobactin biosynthesis and uptake system. Infect Immun v. 70, p. 5913-5923, 2002.

BUSTAMANTE, V. H.; VILLALBA, M. I.; GARCIA-ÂNGULO, V. A.; VAZQUEZ, A.; MARTINEZ, L. C.; JIMENEZ, R.; PUENTE, J. L. PerC and GrIA independently regulate Ler expression in enteropathogenic Escherichia coli. Mol Microbiol v. 82, p. 398-415, 2011.

CARVALHO, V. M.; GYLES, C. L.; ZIEBELL, K.; RIBEIRO, M. A.; CATÃO-DIAS, I. L. S.; OTMAN, J.; KELLER, R.; TRABULSI, L. R.; CASTRO, A. F. P. Characterization of Monkey enteropathogenic Escherichia coli (EPEC) and human typical and atypical EPEC serotype isolates from neotropical nonhuman primates. $\mathbf{J}$ of Clin Microb v. 41, N. 3, p. 1225-1234, 2003.

CERI, H.; OLSON, M. E.; STREMICK, C.; READ, R. R.; MORCK, D.; BURET, A. The Calgary Biofilm Device: new technology for rapid determination of antibiotic susceptibilities of bacterial biofilms. J Clin Microbiol v. 37, p. 1771-1776, 1999.

CHANDRA, B. K.; SINGH, G.; TANEJA, N.; PAHIL, S.; SINGHI, S.; SHARMA, M. Diarrhoeagenic Escherichia coli as a predominant cause of paediatric nosocomial diarrhea in India. J Med Microb v. 61, p. 830-836, 2012.

CHEN, C. Y.; WU, K. M.; CHANG, Y. C.; CHANG, C. H.; TSAI, H. C.; LIAO, T. L.; LIU, Y. M.; 
CHEN, H. J.; SHEN, A. B. T.; LI, J. C.; SU, T. L.; SHAO, C. P.; LEE, C. T.; HOR, L. I.; TSAI, $\mathrm{S}$. F. Comparative genome analysis of Vibrio vulnificus, a marine pathogen. Genome Res v. 13, 2577-2587, 2003.

CHEN, G.; SWEM, L. R.; SWEM, D. L.; STAUFF, D. L.; O'LOUGHLIN, C. T.; JEFFREY, P. D.; BASSLER, B. L.; HUGHSON, F. M. A strategy for antagonizing quorum sensing. Mol Cell v. 42, p. 199-209, 2011.

CHEN, G.; JEFFREY, P. D.; FUQUA, C.; SHI, Y.; CHEN, L. Structural basis for antiactivation in bacterial quorum sensing. Proceed Nat Acad Sci v. 104, p. 16474-16479, 2007.

CHEN, J.; LEE, S. M.; MAO, Y. Protective Effect of Exopolysaccharide Colanic Acid of Escherichia coli O157:H7 to Osmotic and Oxidative Stress. Int J Food Microbiol, v. 93, p. 281-286, 2004.

CHEN, X.; SCHAUDER, S.; POTIER, N.; VAN DORSSELAER, A.; PELCZER, I.; BASSLER, B. L.; HUGHSON, F. M. Structural identification of a bacterial quorum-sensing signal containing boron. Nature v. 415, p. 545, 2002.

CHILCOTT, G. S.; HUGHES, K. T. Coupling of Flagellar Gene Expression to Flagellar Assembly in Salmonella enterica Serovar Typhimurium and Escherichia coli. Microbiol Mol Biol Reviews v. 64, p. 694-708, 2000.

CHRISTENSEN, G. D.; SIMPSON, W. A.; YOUNGER, J. J.; BADDOUR, L. M.; BARRETT, F. F.; MELTON, D. M.; BEACHEY, E. H. Adherence of coagulase-negative Staphylococci to plastic tissue culture plates: a quantitative model for the adherence of Staphylococci to medical devices. J Clin Microbiol v. 22, p. 996-1006, 1985.

CHRISTENSEN, G. D.; SIMPSON, W. A.; BISNO, A. L.; BEACHEY, E. H. Phenotypic variation of Staphylococcus epidermidis slime production in vitro and in vivo. Infect Immun v. 55, p. 622-628, 1982.

CLARKE, M. B.; HUGHES, D. T.; ZHU, C.; BOEDEKER, E. C.; SPERANDIO, V. The QseC sensor kinase: a bacterial adrenergic receptor. Proceed Nat Acad Sci v. 103, p. 1042010425, 2006.

CLARKE, M. B.; SPERANDIO, V. Transcriptional regulation of flhDC by QseBC and $\sigma 28$ (FliA) in enterohaemorrhagic Escherichia coli. Mol Microbiol v. 57, p. 1734-1749, 2005.

COLE, S. P.; HARWOOD, J.; LEE, R.; SHE, R.; GUINEY, D. G. Characterization of monospecies biofilm formation by Helicobacter pylori. J Bacteriol v. 186, 3124-3132, 2004.

CONNELL, I.; AGACE, W.; KLEMM, P.; SCHEMBRI, M.; MĂRILD, S.; SVANBORG, C. Type 1 fimbrial expression enhances Escherichia coli virulence for the urinary tract. Proc Natl Acad Sci v. 93, p. 9827-9832, 1996.

CONTRERAS, C. A.; OCHOA, T. J.; RUIZ, J.; LACHER, D. W.; DURAND, D.; DEBROY, C.; CLEARY, T. G. Genetic diversity of locus of enterocyte effacement genes of enteropathogenic Escherichia coli isolated from Peruvian children. J Med Microbiol v. 61, p. 1114-1120, 2012.

COOKSON, A. L.; COOLEY, W. A.; WOODWARD, M.J. The role of type 1 and curli fimbriae of Shiga toxin-producing Escherichia coli in adherence to abiotic surfaces. Int $\mathbf{J}$ Med Microbiol v. 292, p. 195-205, 2002. 
COSTERTON, J. W.; STEWART, P. S.; GREENBERG, E. P. Bacterial biofilms: a common cause of persistent infections. Science v. 284, p. 1318-1322, 1999.

COSTERTON, J. W.; LEWANDOWSKI, Z.; CALDWELL, D. E.; KORBER, D. R.; LAPPINSCOTT, H. M. Microbial biofilms. Ann Rev Microbiol v. 49, p. 711-745, 1995.

COSTERTON, J. W.; CHENG, K. J.; GEESEY, G. G.; LADD, T. I.; NICKEL, J. C.; DASGUPTA, M.; MARRIE, T. J. Bacterial biofilms in nature and disease. Ann Rev Microbiol v. 41 , p. $435-464,1987$.

CROXEN, M. A.; LAW, R. J.; SCHOLZ, R.; KEENEY, K.M.; WLODARSKA, M.; FINLAY, B. $B$. Recent advances in understanding enteric pathogenic Escherichia coli. Clin Microbiol Rev v. 26, p. 822-880, 2013.

CULLER, H. F.; COUTO, S. C.; HIGA, J. S.; RUIZ, R. M.; YANG, M. J.; BUERIS, V.; FRANZOLIN, M. R.; SIRCILI, M. P. Role of SdiA on Biofilm Formation by Atypical Enteropathogenic Escherichia coli. Genes v. 9, p. 253, 2018.

CULLER, H. F. Envolvimento dos genes qseC e sdiA na formação de biofilme por Escherichia coli enteropatogênica atípica. 20-01-2015. 135 p. Tese - Universidade Estadual de Campinas, Campinas.

CULLER, H. F.; MOTA, C. M.; ABE, C. M.; ELIAS, W. P.; SIRCILI, M. P.; FRANZOLIN, M. R. Atypical enteropathogenic Escherichia coli strains form biofilm on abiotic surfaces regardless of their adherence pattern on cultured epithelial cells. BioMed Res Intern 2014.

DAHLBERG, C.; BERGSTROM, M.; HERMANSSON, M. In situ detection of high levels of hor izontal plasmid transfer in marine bacterial communities. Appl Environ Microbiol v. 64, p.2670-2675, 1998.

DALY, B.; BETTS, W. B.; BROWN, A. P.; O'NEILL, J. G. Bacterial loss from biofilms exposed to free chlorine. Microbios v. 96, p. 7-21, 1998.

DANESE, P. N.; PRATT, L. A.; KOLTER, R. Exopolysaccharide Production Is Required for Development of Escherichia coli K-12 Biofilm Architecture. J Bacteriol v. 182, p. 3593-3596, 2000.

DATSENKO, K. A.; WANNER, B. L. One-step inactivation of chromosomal genes in Escherichia coli K-12 using PCR products. Proc Natl Acad Sci USA v. 97, p. 6640-6645, 2000.

DAVEY, M. E.; O'TOOLE, G. Microbial biofilms: from ecology to molecular genetics. Microbiol Mol Biol Rev v. 64, p. 847-867, 2000.

DAVIES, D. G.; PARSEK, M. R.; PEARSON, J. P.; IGLEWSKI, B. H.; COSTERTON, J. W.; GREENBERG, E. P. The involvement of cell-to-cell signals in the development of a bacterial biofilm. Science v. 280, p. 295-298, 1998.

DAY, W. A.; MAURELLI, A. T. Shigella flexneri LuxS quorum-sensing system modulates virB expression but is not essential for virulence. Infect Immun v. 69, p. 15-23, 2001.

DE ALMEIDA, P. M. P.; ARAIS, L. R.; ANDRADE, J. R. C.; PRADO, E. H. R. B.; IRINO, K.; CERQUEIRA, A. D. M. F. Characterization of atypical Enteropathogenic Escherichia coli (aEPEC) isolated from dogs. Vet Microbiol v. 158, p. 420-424, 2012. 
DE KEERSMAECKER, S. C.; VARSZEGI, C.; VAN BOXEL, N.; HABEL, L. W.; METZGER, K.; DANIELS, R.; MACHAL, K.; DE VOS, D.; VANDERLEYDEN, J. Chemical synthesis of (S)-4, 5-dihydroxy-2, 3-pentanedione, a bacterial signal molecule precursor, and validation of its activity in Salmonella typhimurium. J Biol Chem v. 280, p. 19563-19568, 2005.

DE WULF, P.; MCGUIRE, A.M.; LIU, X.; LIN, E.C. Genome-Wide Profiling of Promoter Recognition by the Two-Component Response Regulator CpxR-P in Escherichia coli. J Biol Chem v. 277, p. 26652-26661, 2002.

DEEP, A.; CHAUDHARY, U.; GUPTA, V. Quorum sensing and bacterial pathogenicity: from molecules to disease. J Lab Phys v. 3, p. 4, 2011.

DENG, W.; PUENTE, J.L.; GRUENHEID, S.; LI, Y.; VALLANCE, B. A.; VÁZQUEZ, A.; BARBA, J.; IBARRA, J. A.; O'DONNELL, P.; METALNIKOV, P.; ASHMAN, K.; LEE, S.; GOODE, D.; PAWSON, T.; FINLAY, B. B. Dissecting virulence: systematic and functional analyses of a pathogenicity island. Proc Natl Acad Sci v. 101, p. 3597-3602, 2004.

DENG, Y.; WU, J.; TAO, F.; ZHANG, L. H. Listening to a new language: DSF-based quorum sensing in Gram-negative bacteria. Chem Rev v. 111, p. 160-173, 2011.

DESJARDIM, J. A.; FALAGAS, M. E.; RUTHAZER, R.; GRIFFITH, J.; WAWROSE, D.; SCHENKEIN, D.; MILLER, K.; SNYDMAN, D. R. Clinical utility of blood cultures drawn from indwelling central venous catheres in hospitalized patients with cancer. Ann Intern Med v. 131, p. 641-647, 1999.

DIAS, R. C. B.; SANTOS, B. C. D.; SANTOS, L. F. D.; VIEIRA, M. A.; YAMATOGI, R. S.; MONDELLI, A. L.; SADATSUNE, T.; SFORCIN, J. M.; GOMES, T. A. T.; HERNANDES, R. T. Diarrheagenic Escherichia coli pathotypes investigation revealed atypical enteropathogenic E. coli as putative emerging diarrheal agents in children living in Botucatu, São Paulo State, Brazil. APMIS v. 124, p. 299-308, 2016.

DIGGLE, S. P.; GRIFFIN, A. S.; CAMPBELL, G. S.; WEST, S. A. Cooperation and conflict in quorum-sensing bacterial populations. Nature v. 45, p. 411, 2007.

DiMANGO, E.; ZAR, H. J.; BRYAN, R.; PRINCE, A. Diverse Pseudomonas aeruginosa gene products stimulate respiratory epithelial cells to produce interleukin-8. J Clin Inv v. 96, p. 2204-2210, 1995.

DO VALLE, G. R.; GOMES, T. A. T.; IRINO, K.; TRABULSI, L. R. The traditional enteropathogenic Escherichia coli (EPEC) serogroup 0125 comprises serotypes which are mainly associated with the category of enteroaggregative E. coli. FEMS Microbiol Letters v. 152, p. 95-100, 1997.

DOMKA, J.; LEE, J.; WOOD, T. K. YliH (BssR) and YceP (BssS) regulate Escherichia coli K12 biofilm formation by influencing cell signaling. Appl Environ Microbiol v. 72, p. 24492459, 2006.

DONG, Y. H.; WANG, L. H.; XU, J. L.; ZHANG, H. B.; ZHANG, X. F.; ZHANG, L. H. Quenching quorum-sensing-dependent bacterial infection by an $\mathrm{N}$-acyl homoserine lactonase. Nature v. 411, p. 813, 2001.

DONLAN, R. M. Biofilms: microbial life on surfaces. Emerg Infect Dis v. 8, p. 881-90, 2002.

DONLAN, R. M.; COSTERTON J. W. Biofilms: survival mechanisms of clinically relevant microorganisms. Clin Microbiol Rev v. 15, p. 167-193, 2002. 
DONNENBERG, M. S.; TACKET, C. O.; JAMES, S. P.; LOSONSKY, G.; NATARO, J. P.; WASSERMAN, S. S.; KAPER, J. B.; LEVINE, M. M. Role of the eaeA gene in experimental enteropathogenic Escherichia coli infection. J Clin Investig v. 92, p.1412-1417, 1993.

DOREL, C.; VIDAL, O.; PRIGENT-COMBARET, C.; VALLET, I.; LEJEUNE, P. Involvement of the Cpx signal transduction pathway of $E$. coli in biofilm formation. FEMS Microbiol Letters v. 178, p. 169-175, 1999.

DUDIN, O.; GEISELMANN, J.; OGASAWARA, H.; ISHIHAMA, A.; LACOUR, S. Repression of flagellar genes in exponential phase by CsgD and CpxR, two crucial modulators of Escherichia coli biofilm formation. J Bacteriol v. 196, p. 707-715, 2014.

DUNNE, W. M. Bacterial adhesion: Seen any good biofilms lately? Clin Microbiol Ver v. 15, p. 155-166, 2002.

DUNNY, G. M.; LEONARD, B. A. Cell-cell communication in Gram-positive bacteria. Ann Rev Microbiol v. 51, p. 527-564, 1997.

DYSZEL, J. L.; SMITH, J. N.; LUCAS, D. E.; SOARES, J. A.; SWEARINGEN, M. C.; VROSS, M. A.; YOUNG, G. M.; AHMER, B. M. M. Salmonella enterica serovar Typhimurium can detect acyl homoserine lactone production by Yersinia enterocolitica in mice. J Bacteriol v. 192, p. $29-37,2010$.

DYSZEL, J. L.; SOARES, J. A.; SWEARINGEN, M. C.; LINDSAY, A.; SMITH, J. N.; AHMER, M. M. E.coli K-12 and EHEC genes regulated by SdiA. PLoS ONE v. 5, e8946, 2010.

DZIVA, F.; VAN DIEMEN, P. M.; STEVENS, M. P.; SMITH, A. J.; WALLIS, T. S. Identification of Escherichia coli O157:H7 genes influencing colonization of the bovine gastrointestinal tract using signature-tagged mutagenesis. Microbiol v. 150, p. 3631-3645, 2004.

ECKBURG, P.B.; BIK, E. M.; BERNSTEIN, C. N.; PURDOM, E.; DETHLEFSEN, L.; SARGENT, M.; GILL, S. R.; NELSON, K. E.; RELMAN, D. A. Diversity of the human intestinal microbial flora. Science v. 308, p. 1635-1638, 2005.

EDRINGTON, T. S.; FARROW, R. L.; SPERANDIO, V.; HUGHES, D. T.; LAWRENCE, T. E.; CALLAWAY, T. R.; ANDERSON, R. C.; NISBET, D. J. Acyl-homoserine-lactone autoinducer in the gastrointestinal tract of feedlot cattle and correlation to season, E. coli O157:H7 prevalence, and diet. Curr Microbiol v. 58, p. 227-232, 2009.

ELIAS, M.; TAWFIK, D. S. Divergence and convergence in enzyme evolution: parallel evolution of paraoxonases from quorum-quenching lactonases. J Biol Chem v. 287, p. 1120, 2012.

ELLIOTT, S. J.; SPERANDIO, V.; GIRÓN, J. A.; SHIN, S.; MELLIES, J. L.; WAINWRIGHT, L.; HUTCHESON, S. W.; MCDANIEL, T. K.; KAPER, J. B. The locus of enterocyte effacement (LEE)- encoded regulator controls expression of both LEE- and non-LEEencoded virulence factors in enteropathogenic and enterohemorrhagic Escherichia coli. Infect Immun v. 68, p. 6115-6126, 2000.

ELLIOTT, S. J.; WAINWRIGHT, L.; MCDANIEL, T. K.; MCNAMARA, B. P.; DONNENBERG, M. S.; KAPER, J. B. The complete sequence of locus of enterocyte effacement (LEE) from enteropathogenic Escherichia coli E2348/69. Mol Microbiol v. 28, p. 1-4, 1998.

ENG, R. H.; PADBERG, F. T.; SMITH, S. M.; TAN, E. N.; CHERUBIN, C. E. Bactericidal effects of antibiotics on slowly growing and nongrowing bacteria. Antimicrob Agen Chem v. 
35, p. 1824-1828, 1991.

ENGEBRECHT, J.; NEALSON, K.; SILVERMAN, M. Bacterial bioluminescence: isolation and genetic analysis of functions from Vibrio fischeri. Cell v. 32, p. 773-781, 1983.

ERICKSON, D. L.; NSEREKO, V. L.; MORGAVI, D. P.; SELINGER, L. B.; RODE, L. M.; BEAUCHEMIN, K. A. Evidence of quorum sensing in the rumen ecosystem: detection of $\mathrm{N}$ acyl homoserine lactone autoinducers in ruminal contents. Can $\mathbf{J}$ Microbiol v. 48, p. $374-$ 378, 2002.

EWING, W.H. Edwards and Ewing's Identification of the Enterobacteriaceae. Int J Syst Evo Microbiol v. 36, p. 581-582, 1986.

FAILLE, C.; JULLIEN, C.; FONTAINE, F.; BELLON-FONTAINE, M. N.; SLOMIANNY, C.; BENEZECH, T. Adhesion of Bacillus spores and Escherichia coli cells to inert surfaces: role of surface hydrophrobicity. Can J Microbiol v. 48, p. 728-38, 2002.

FANNING, S.; HALL, L. J.; CRONIN, M.; ZOMER, A.; MACSHARRY, J.; GOULDING, D.; MOTHERWAY, M. O.; SHANAHAN, F.; NALLY, K.; DOUGAN, G.; Van SINDEREN, D. Bifidobacterial surface-exopolysaccharide facilitates commensal-host interaction through immune modulation and pathogen protection. Proceed Nat Acad Sci v. 109, p. 2108-2113, 2012.

FEDERLE, M. J. Autoinducer-2-based chemical communication in bacteria: complexities of interspecies signaling. Bact Sens Signal v. 16, p. 18-32, 2009.

FEDERLE, M. J.; BASSLER, B. L. Interspecies communication in bacteria. J Clin Inv v. 112, p. 1291-1299, 2003.

FÉLIX, M. A.; BARKOULAS, M. Pervasive robustness in biological systems. Nat Rev Gen v. 16 , p. 483, 2015.

FERRIÈRES, L.; HANCOCK, V.; KLEMM, P. Specific selection for virulent urinary tract infectious Escherichia coli strains during catheter-associated biofilm formation. FEMS Immun Med Microbiol v. 51, p. 212-219, 2007.

FEY, P. D. Modality of bacterial growth presents unique targets: how do we treat biofilmmediated infections? Curr Opin Microbiol v. 13, p. 610-615, 2010.

FINLAY, B. B.; ROSENSHINE, I.; DONNENBERG, M. S.; KAPER, J. B. Cytoskeletal composition of attaching and effacing lesions associated with enteropathogenic Escherichia coli adherence to HeLa cells. Infect Immun v. 60, p. 2541-2543, 1992.

FLEMMING, H.; WINGENDER, J. The biofilm matrix. Nature Rev Microbiol v. 8, n. 9, p. 623, 2010.

FLEMMING, H. C.; LEIS, A. In: Encyclopedia of Environmental Microbiology Ed. Bitton, p. 2958-2967 Wiley, New York, 2002.

FOSTER, M. A.; IQBAL, J.; ZHANG, C.; MCHENRY, R.; CLEVELAND, B. E.; ROMEROHERAZO, Y.; FONNESBECK, C.; PAYNE, D. C.; CHAPPELL, J. D.; HALASA, N.; GÓMEZDUARTE, O. G. Enteropathogenic and enteroaggregative $E$. coli in stools of children with acute gastroenteritis in Davidson County, Tennessee. Diagn Microbiol Infect Dis v. 83, p. 319-324, 2015. 
FOXMAN, B. The epidemiology of urinary tract infection. Nature Rev Urol v. 7, p. 653, 2010.

FOXMAN, B.; BROWN, P. Epidemiology of urinary tract infections: transmission and risk factors, incidence, and costs. Infect Dis Clin N Ame v. 17, p. 227-241, 2003.

FRANZOLIN, M. R.; ALVES, R. C. B.; KELLER, R.; GOMES, T. A. T.; BEUTIN, L.; BARRETO, M. L.; MILROY, C.; STRINA, A.; RIBEIRO, H.; TRABULSI, L. R. Prevalence of diarrheagenic Escherichia coli in children with diarrhea in Salvador, Bahia, Brazil. Mem Inst Oswaldo Cruz v. 100, p. 359-363, 2005.

FRATAMICO, P. M.; DEBROY, C.; LIU, Y.; NEEDLEMAN, D. S.; BARANZONI, G. M.; FENG, P. Advances in Molecular Serotyping and Subtyping of Escherichia coli. Frontiers Microbiol v. 7, Art. 644, p. 1-8, 2016.

FREESTONE, P. P.; HAIGH, R. D.; WILLIAMS, P. H.; LYTE, M. Involvement of enterobactin in norepinephrine-mediated iron supply from transferrin to enterohaemorrhagic. FEMS Microbiol Letters v. 222, p. 39-43, 2003.

FUKUDA, S.; TOH, H.; HASE, K.; OSHIMA, K.; NAKANISHI, Y.; YOSHIMURA, K.; TOBE, T.; CLARKE, J. M.; TOPPING, D. L.; SUZUKI, T.; TAYLOR, T. D.; ITOH, K.; KIKUCHI, J.; MORITA, H.; HATTORI, M.; OHNO, H. (2011). Bifidobacteria can protect from enteropathogenic infection through production of acetate. Nature v. 469, p. 543, 2011.

FUQUA, C.; GREENBERG, E. P. Self perception in bacteria: quorum sensing with acylated homoserine lactones. Curr Opin Microbiol v. 1, p. 183-189, 1998.

FUQUA, W. C.; WINANS, S. C.; GREENBERG, E. P. 1994. Quorum sensing in bacteria: the LuxR-Luxl family of cell density-responsive transcriptional regulators. J Bacteriol v. 176, p. 269-275, 1994.

GALLOWAY, W. R.; HODGKINSON, J. T.; BOWDEN, S. D.; WELCH, M.; SPRING, D. R. Quorum sensing in Gram-negative bacteria: small-molecule modulation of $\mathrm{AHL}$ and $\mathrm{Al}-2$ quorum sensing pathways. Chem Rev v. 111, p. 28-67, 2010.

GALPERIN, M. Y.;GOMELSKY, M. Bacterial signal transduction modules: from genomics to biology. ASM News v. 71, p. 326, 2005.

GERSTEL, U.; ROMLING, U. The $\operatorname{csg} D$ promoter, a control unit for biofilm formation in Salmonella typhimurium. Res Microb v. 154, p. 659-667, 2003.

GERSTEL, U.; RÖMLING, U. Oxygen tension and nutrient starvation are major signals that regulate agfD promoter activity and expression of the multicellular morphotype in Salmonella typhimurium. Environ Microbiol v. 3, p. 638-648, 2001.

GILBERT, P.; ALLISON, D. G.; MCBAIN, A. J. Biofilms in vitro and in vivo: do singular mechanisms imply cross-resistance? J Appl Microbiol v. 92, p. S98-S110, 2002.

GIRÓN, J. A.; HO, A. S. Y.; SCHOOLNIK, G.K. An inducible bundle-froming pilus of enteropathogenic Escherichia coli. Science v. 254, p. 710-713, 1991.

GIVSKOV, M.; DE NYS, R.; MANEFIELD, M.; GRAM, L.; MAXIMILIEN, R. I. A.; EBERL, L. E. O.; MOLIN, S.; STEINBERG, P. D.; KJELLEBERG, S. Eukaryotic interference with homoserine lactone-mediated prokaryotic signalling. J Bacteriol v. 178, p. 6618-6622, 1996.

GODE-POTRATZ, C. J.; KUSTUSCH, R. J.; BREHENY, P. J.; WEISS, D. S.; MCCARTER, 
L. L. Surface sensing in Vibrio parahaemolyticus triggers a programme of gene expression that promotes colonization and virulence. Mol Microbiol v. 79, p. 240-263, 2011.

GOFFAUX, F.; CHINA, B.; JANSSEN, L.; MAINIL, J. Genotypic characterization of enteropathogenic Escherichia coli (EPEC) isolated in Belgium from dogs and cats. Res In Microb v. 151, p. 865-871, 2000.

GOMES, T. A. T.; HERNANDES, R.T.; TORRES, A. G.; SALVADOR, F. A.; GUTH, B. E. C.; VAZ, T. M. I.; IRINO, K.; SILVA, R. M.; VIEIRA, M. A. M. Adhesin-encoding genes from Shiga toxin producing Escherichia coli are more prevalent in atypical than in typical enteropathogenic E. coli . J Clin Microbiol v. 49, p. 3334-3337, 2011.

GOMES, T. A. T.; IRINO, K.; GIRÃO, D. M.; GIRÃO, V. B. C.; GUTH, B. E. C.; VAZ, T. M.; MOREIRA, F. C.; CHINARELLI, S. H.; VIEIRA, M. A. M. Emerging enteropathogenic Escherichia coli strains? Emerg Infect Dis v. 10, p. 1851-1855, 2004.

GONZÁLEZ, J. F.; VENTURI, V. A novel widespread interkingdom signaling circuit. Trends Plant Sci v. 18, p. 167-174, 2013.

GONZALEZ-BARRIOS A.F.; ZUO R.; HASHIMOTO Y.; YANG L.; BENTLEY W. E.; WOOD T. K. Autoinducer 2 controls biofilm formation in Escherichia coli through a novel motility quorum-sensing regulator. J Bacteriol v.188, p. 305-316, 2006.

GOVAN, J. R.; DERETIC, V. Microbial pathogenesis in cystic fibrosis: mucoid Pseudomonas aeruginosa and Burkholderia cepacia. Microbiol Rev v. 60, p. 539-574, 1996.

GRAY, K. M.; GAREY, J. R. The evolution of bacterial Luxl and LuxR quorum sensing regulators. Microbiol v. 147, p. 2379-2387, 2001.

GREENBERG, E. P. Bacterial communication and group behavior. J Clin Invest v. 112, p. 1288-1290, 2003.

GREENBERG, E.; HASTINGS, J.; ULITZER, S. Induction of luciferase synthesis in Beneckea harveyi by other marine bacteria. Arch Microbiol v. 120, p. 87-91, 1979.

GRIMM, V.; WESTERMANN, C.; RIEDEL, C. U. Bifidobacteria-host interactions-an update on colonisation factors. BioMed Res Intern, 2014.

GRUBER, C. C.; SPERANDIO, V. Posttranscriptional control of microbe-induced rearrangement of host cell actin. MBio v. 5, e01025-13, 2014.

GU, Z.; STEINMETZ, L. M.; GU, X.; SCHARFE, C.; DAVIS, R. W.; LI, W. H. Role of duplicate genes in genetic robustness against null mutations. Nature v. 421, p. 63, 2003.

GUARNER, F.; MALAGELADA, J. R. Gut flora in health and disease. Lancet v. 361, p. 512519, 2003.

GUCKES, K.R.; KOSTAKIOTI, M.; BRELAND, E. J.; GU, A. P.; SHAFFER, C. L.; MARTINEZ, C. R.; HULTGREN, S. J.; HADJIFRANGISKOU, M. Strong cross-system interactions drive the activation of the $Q$ seB response regulator in the absence of its cognate sensor. P Natl Acad Sci USA v. 110, p. 16592-16597, 2013

GUIEYSSE, B.; WUERTZ, S. Metabolically versatile large-genome prokaryotes. Curr Opin Biotech v. 23, p. 467-473, 2012.

GULLAR, F. Toda Poesia (1950-1980). 2 ed. Rio de Janeiro: Civilização Brasileira v. 300, 
444 p. 1981.

GUTTENPLAN, S. B.; KEARNS, D. B. Regulation of flagellar motility during biofilm formation. FEMS Microbiol Rev v. 37, p. 849-871, 2013.

HADJIFRANGISKOU, M.; KOSTAKIOTI, M.; CHEN, S. L.; HENDERSON, J. P.; GREENE, S. E.; HULTGREN, S. J. A central metabolic circuit controlled by QseC in pathogenic Escherichia coli. Mol Microbiol v.80, p. 1516-1529, 2011.

HAIGH, R.; KUMAR, B.; SANDRINI, S.; FREESTONE, P. Mutation design and strain background influence the phenotype of $E$ scherichia coli luxS mutants. Mol Microbiology v. 88, p. 951-969, 2013.

HAMMAR, M.; ARNQVIST, A.; BIAN, Z.; OLSÉN, A.; NORMARK, S. Expression of two csg operons is required for production of fibronectin and Congo red binding curli polymers in Escherichia coli K-12. Mol Microbiol v. 18, p. 661-670, 1995.

HANCOCK, V.; KLEMM, P. Global gene expression profiling of asymptomatic bacteriuria Escherichia coli during biofilm growth in human urine. Infect Immun v. 75, p. 966-76, 2007.

HEIL, M. Nectar: generation, regulation and ecological functions. Trends Plant Sci v. 16, p. 191-199, 2011.

HENTZER, M.; WU, H.; ANDERSEN, J. B.; RIEDEL, K.; RASMUSSEN, T. B.; BAGGE, N.; KUMAR, N.; SCHEMBRI, M. A.; SONG, Z.; KRISTOFFERSEN, P.; MANEFIELD, M.; COSTERTON, J. W.; MOLIN, S.; EBERL, L.; STEINBERG, P.; KJELLEBERG,, S.; HOIBY, N.; GIVSKOV, M. Attenuation of Pseudomonas aeruginosa virulence by quorum sensing inhibitors. EMBO J v. 22, p. 3803-3815, 2003.

HERZBERG, M.; KAYE, I. K.; PETI, W.; WOOD, T. K. YdgG (TqsA) controls biofilm formation in Escherichia coli K-12 through autoinducer 2 transport. $\mathbf{J}$ Bacteriol v. 188, p. 587-598, 2006.

HINTON, N. A.; MACGREGOR, R. R. A study of infections due to pathogenic serogroups of Escherichia coli. Canad Maj v. 79, p. 359-364, 1958.

HOOPER, L.V.; GORDON, J. I. Commensal host-bacterial relationships in the gut. Science v. 292, p. 1115-1118, 2001.

HSIAO, A.; AHMED, A. S.; SUBRAMANIAN, S.; GRIFFIN, N. W.; DREWRY, L. L.; PETRI, W. A.; HAQUE, R.; AHMED, T.; GORDON, J. I. Members of the human gut microbiota involved in recovery from Vibrio cholerae infection. Nature p. 515, p. 423, 2014.

HU, J.; TORRES, A. G. Enteropathogenic Escherichia coli: foe or innocent bystander? Clin Microbiol Infect v. 21, p. 729-734, 2015.

HUGHES, D. T.; TEREKHOVA, D. A.; LIOU, L.; HOVDE, C. J.; SAHL, J. W.; PATANKAR, A. V.; GONZALEZ, J. E.; EDRINGTON, T. S.; RASKO, D. A.; SPERANDIO, V. Chemical sensing in mammalian host-bacterial commensal associations. Proceed Nat Acad Sci v. 107, p. 9831-9836, 2010.

HUGHES, D. T.; CLARKE, M. B.; YAMAMOTO, K.; RASKO, D. A.; SPERANDIO, V. The QseC adrenergic signaling cascade in enterohemorrhagic $E$. coli (EHEC). PLOS Pathogens v. 5, e1000553, 2009. 
HUGHES, D. T.; SPERANDIO, V. Inter-kingdom signalling: communication between bacteria and their hosts. Nature Rev Microbiol v. 6, p. 111, 2008.

HULL, R. A.; GILL, R. E.; HSU, P.; MINSHEW, B. H.; FALKOW, S. Construction and expression of recombinant plasmids encoding type I or D-Mannose-Resistant pili from a urinary tract infection Escherichia coli isolate. Infect Immun v. 33, p. 933-938, 1981.

HUMPHRIES, R. M.; ARMSTRONG, G. D. Sticky situation: localized adherence of enteropathogenic Escherichia coli to the small intestine epithelium. Fut Microbiol v. 5, p. 1645-1661, 2010.

HYMAN, M.; MANN, L. T. The nitrite reaction as an indicator of urinary infection. $\mathbf{J}$ Urol $\mathrm{p}$. 521-526, 1929.

ISHII, S.; MEYER, K. P.; SADOWSKY, M. J. Relationship between Phylogenetic Groups, Genotypic Clusters, and Virulence Gene Profiles of Escherichia coli Strains from Diverse Human and Animal Sources. Appl Environ Microbiol v. 73, p. 5703-5710, 2007.

ISMAIL, A. S.; VALASTYAN, J. S.; BASSLER, B. L. A host-produced autoinducer-2 mimic activates bacterial quorum sensing. Cell Host Microbe v. 19, p. 470-480, 2016.

ITO, A.; TANIUCHI, A.; MAY, T.; KAWATA, K.; OKABE, S. Increased antibiotic resistance of Escherichia coli in mature biofilms. Appl Environ Microbiol v.75, p. 4093-4100, 2009.

JACOBI, C. A.; BACH, A.; EBERL, L.; STEIDLE, A.; HEESEMANN, J. Detection of $N$-(3oxohexanoyl)-L-homoserine lactone in mice infected with Yersinia enterocolitica serotype O8. Infect Immun v. 71, p. 6624-6626, 2003.

JACOBSEN, S. Á.; STICKLER, D. J.; MOBLEY, H. L. T.; SHIRTLIFF, M. E. Complicated catheter-associated urinary tract infections due to Escherichia coli and Proteus mirabilis. Clin Microbiol Rev v. 21, p. 26-59, 2008.

JAMES, D.; SHAO, H.; LAMONT, R. J.; DEMUTH, D. R. The Actinobacillus actinomycetemcomitans ribose binding protein $\mathrm{RbsB}$ interacts with cognate and heterologous autoinducer 2 signals. Infect Immun v. 74, p. 4021-4029, 2006.

JIMÉNEZ AMADOR, H.; CASAN CLARÀ, P. Bacterial communication and human communication: what can we learn from quorum sensing? Arch Bronconeum (English Edition) v. 48, p. 305-307, 2012.

JOHNSON, M. R.; MONTERO, C. I.; CONNERS, S. B.; SHOCKLEY, K. R.; BRIDGER, S. L.; KELLY, R. M. Population density-dependent regulation of exopolysaccharide formation in the hyperthermophilic bacterium Thermotoga maritima. Mol Microbiol v. 55, p. 664-674, 2005.

JUÁREZ-RODRÍGUEZ, M. D.; TORRES-ESCOBAR, A.; DEMUTH, D. R. Transcriptional regulation of the Aggregatibacter actinomycetemcomitans ygiW-qseBC operon by QseB and integration host factor proteins. Microbiol v. 160, p. 2583-2594, 2014.

JURETSCHKO, S.; LOY, A.; LEHNER, A.; WAGNER, M. The microbial community composition of a nitrifying-denitrifying activated sludge from na industrial sewage treatment plant analyzed by the full-cycle rRNA approach. Syst Appl Microbiol v. 25, p. 84-99, 2002.

KAHN, D.; DITTA, G. Modular structure of FixJ: homology of the transcriptional activator domain with the -35 binding domain of sigma factors. Mol Microbiol v. 5, p. 987-997, 1991.

KANAMARU, K.; KANAMARU, K.; TATSUNO, I.; TOBE, T.; SASAKAWA, C. SdiA, an 
Escherichia coli homologue of quorum-sensing regulators, controls the expression of virulence factors in enterohaemorrhagic Escherichia coli O157: H7. Mol Microbiol v. 38, p. 805-816, 2000.

KAPER, J. B.; NATARO, J. P.; MOBLEY, H. L. T. Pathogenic Escherichia coli. Nat Rev Microbiol v. 2, p. 123-138, 2004.

KAPER, J. B. Defining enteropathogenic Escherichia coli. Rev Microbiol v. 27, p. 130-133, 1996.

KASAI, S. Freshwater bioluminescence in Vibrio albensis (Vibrio cholerae biovar albensis) NCIMB 41 is caused by a two-nucleotide deletion in luxO. J Biochem v. 139, p. 471-482, 2006.

KELLY, R. C.; BOLITHO, M. E.; HIGGINS, D. A.; LU, W.; NG, W. L.; JEFFREY, P. D.; RABINOWITZ, J. D.; SEMMELHACK, M. F.; HUGHSON, F. M.; BASSLER, B. L. The Vibrio cholerae quorum-sensing autoinducer CAl-1: Analysis of the biosynthetic enzyme CqsA. Nat Chem Biol v. 5, p. 891-895, 2009.

KENDALL, M. M.; RASKO, D. A.; SPERANDIO, V. Global effects of the cell-to-cell signaling molecules autoinducer-2, autoinducer-3, and epinephrine in a luxS mutant of enterohemorrhagic Escherichia coli. Infect Immun v. 75, p. 4875-4884, 2007.

KIM, M. Y.; PARK, R. Y.; CHOI, M. H.; SUN, H. Y.; KIM, C. M.; KIM, S. Y.; SHIN, S. H. Swarming differentiation of Vibrio vulnificus downregulates the expression of the $v v h B A$ hemolysin gene via the LuxS quorum-sensing system. J Microbiol v. 44, p. 226-232, 2006.

KITANO, H. Biological robustness. Nat Rev Gen v. 5, p. 826, 2004.

KJELLEBERG, S.; MOLIN, S. Is there a role for quorum sensing signals in bacterial biofilms? Curr Opin Microbiol v. 5, p. 254-258, 2002.

KLAUSEN, M.; HEYDORN, A.; RAGAS, P.; LAMBERTSEN, L.; AAES-JORGENSEN, A.; MOLIN, S.; TOLKER-NIELSEN, T. Biofilm formation by Pseudomonas aeruginosa wild type, flagella and type IV pili mutants. Mol Microbiol v. 48, p. 1511-1524, 2003.

KNUTTON, S.; DALDWIN, T.; WILLIAMS, P. H.; McNEISH, A. S. Actin accumulation at sites of bacterial adhesion to tissue culture cells: basis of a new dianostic test for enteropathogenic and enterohaemorragic Escherichia coli. Infect Immun v. 57, p. 12901298, 1989.

KNUTTON, S.; BALDINI, M. M.; KAPER, J. B.; MCNEISH, A. S. Role of plasmid encoded factors in adhesion of enteropathogenic Escherichia coli to HEp-2 cells. Infect Immum v. 55, p. 78-85, 1987.

KOCH, C.; HOIBY, N. Pathogenesis of cystic fibrosis. Lancet v. 341, p. 1065-1069, 1993.

KOLENDA, R.; BURDUKIEWICZ, M.; SCHIERACK, P. A systematic review and metaanalysis of the epidemiology of pathogenic Escherichia coli of calves and the role of calves as reservoirs for human pathogenic E. coli. Front Cell Infect Microbiol v. 5, p. 23, 2015.

KOONIN, E. V.; WOLF, Y. I. Constraints and plasticity in genome and molecular-phenome evolution. Nat Rev Gen v. 11, p. 487, 2010.

KOSTAKIOTI, M.; HADJIFRANGISKOU, M.; CUSUMANO, C. K.; HANNAN, T. J.; JANETKA, 
J. W.; HULTGREN, S. J. Distinguishing the contribution of type 1 pili from that of other QseBmisregulated factors when $\mathrm{QseC}$ is absent during urinary tract infection. Infect Immun IAI00283, 2012.

KOSTAKIOTI, M.; HADJIFRANGISKOU, M.; PINKNER, J. S.; HULTGREN, S. J. QseCmediated dephosphorylation of QseB is required for expression of genes associated with virulence in uropathogenic Escherichia coli. Mol Microbiol v. 73, p. 1020-1031, 2009.

KRAUSE, G.; ZIMMERMANN, S.; BEUTIN, L. Investigation of domestic animals and pets as a reservoir for intimin- (eae) gene positive Escherichia coli types. Vet Microbiol v. 106, p. 87-95, 2005.

KRIN, E.; CHAKROUN, N.; TURLIN, E.; GIVAUDAN, A.; GABORIAU, F.; BONNE, I.; MARISA, L. Pleiotropic role of quorum-sensing autoinducer 2 in Photorhabdus luminescens. Appl Environ Microbiol v. 72, p. 6439-6451, 2006.

KURAMITSU, H. K.; WANG, B. Y. The whole is greater than the sum of its parts: dental plaque bacterial interactions can affect the virulence properties of cariogenic Streptococcus mutans. Am J Dent v. 24, p. 153-154, 2011.

LABBATE, M.; QUECK, S. Y.; KOH, K. S.; RICE, S. A.; GIVSKOV, M.; KJELLEBERG, S. Quorum sensing-controlled biofilm development in Serratia liquefaciens MG1. J Bacteriol v. 186, p. 692-698, 2004.

LAGANENKA, L.; COLIN, R.; SOURJIK, V. Chemotaxis towards autoinducer 2 mediates autoaggregation in Escherichia coli. Nat Commun v. 7, p. 12984, 2016.

LAZAZZERA, B. A. Quorum sensing and starvation: signals for entry into stationary phase. Curr Opin Microbiol v. 3, p. 177-182, 2000.

LEBARON, P.; BAUDE, P.; LETT, M. C.; DUVAL-IFLAH, Y.; SIMONET, P.; JACQ, E.; FRANK, N.; ROUX, B.; BALEUX, B.; FAURIE, G.; HUBERT, J. C.; NORMAND, P.; PRIEUR, D.; SCHMIDT, S.; BLOCK, J. C. Recombinant plasmid mobilization between E. coli strains in seven sterile microcosms. Can J Microbiol v. 43, p. 534-40, 1997.

LEE, J.; MAEDA, T.; HONG, S. H.; WOOD, T. K. Reconfiguring the Quorum-Sensing regulator SdiA of Escherichia coli to control biofilm formation via indole and $\mathrm{n}$ acylhomoserine lactones. Appl Environ Microb v. 75, p. 1703-1716, 2009.

LEE, J.; ZHANG, X. S.; HEGDE, M. W.; BENTLEY, E.; JAYARAMAN, A.; WOOD, T. K. Indole cell signaling occurs primarily at low temperatures in Escherichia coli. ISME $\mathbf{J}$ v. 2, p.1007-1023, 2008.

LEE, J.; JAYARAMAN, A.; WOOD, T. K. Indole is an inter-species biofilm signal mediated by SdiA. BMC Microbiol v. 7, p. 42, 2007.

LEE, S. F.; LI, Y. H.; BOWDEN, G. H. Detachment of Streptococcus mutans biofilm cells by an endogenous enzymatic activity. Infect Immun v. 64, p. 1035-1038, 1996.

LEJEUNE, P. Contamination of abiotic surfaces: what a colonizing bacterium sees and how to blur it. Trends Microbiol v. 11, p. 179-184, 2003.

LEMON, K. P.; HIGGINS, D. E.; KOLTER, R. Flagellar motility is critical for Lysteria monocytogenes biofilm formation. J Bacteriol v. 489, p. 4418-4424, 2007.

LENZ, D. H.; MILLER, M. B.; ZHU, J.; KULKARNI, R. V.; BASSLER, B. L. CsrA and three 
redundant small RNAs regulate quorum sensing in Vibrio cholerae. Mol Microbiol v. 58, p. 1186-1202, 2005.

LEOMIL, L.; CASTRO, A. F. P.; KRAUSE, G.; SCHMIDT, H.; BEUTIN, L. Characterization of two major groups of diarrheagenic Escherichia coli O26 strains which are globally spread in human patients and domestic animals of different species. FEMS Microb Letters v. 249, p. 335-342, 2005.

LEVINE, M.M.; EDELMAN, R. Enteropathogenic Escherichia coli of classic serotypes associated with infant diarrhea: epidemiology and pathogenesis. Epidemiol Rev v. 6, p. 31$51,1984$.

LI, J.; YUAN, Z.; ZHANG, Z. The cellular robustness by genetic redundancy in budding yeast. PLoS Gen v. 6, e1001187, 2010.

LI, Y. H.; TIAN, X. Quorum sensing and bacterial social interactions in biofilms. Sensors v. 12, p. 2519-2538, 2012.

LICHT, T. R.; CHRISTENSEN, B. B.; KROGFELT, K. A.; MOLIN, S. Plasmid transfer in the animal intestine and other dynamic bacterial populations: the role of community structure and environment. Microbiol v. 145, p. 2615-2622, 1999.

LIN, Y. H.; XU, J. L.; HU, J.; WANG, L. H.; ONG, S. L.; LEADBETTER, J. R.; ZHANG, L. H. Acyl-homoserine lactone acylase from Ralstonia strain XJ12B represents a novel and potent class of quorum-quenching enzymes. Mol Microbiol v. 47, p. 849-860, 2003.

LING, H.; KANG, A.; TAN, M. H.; QI, X.; CHANG, M. W. The absence of the luxS gene increases swimming motility and flagella synthesis in Escherichia coli K12. Biochem Biophys Res Commun v. 401, p. 521-526, 2010.

LINTZ, M. J.; OINUMA, K. I.; WYSOCZYNSKI, C. L.; GREENBERG, E. P.; CHURCHILL, M. E. Crystal structure of QscR, a Pseudomonas aeruginosa quorum sensing signal receptor. Proceed Nat Acad Sci, 2011.

LOMBARdíA, E.; ROVETtO, A. J.; ARABOLAZA, A. L.; GRAU, R. R. A LuxS-dependent cell-to-cell language regulates social behavior and development in Bacillus subtilis. $\mathbf{J}$ Bacteriol v. 188, p. 4442-4452, 2006.

LOZER, D. M.; SOUZA, T. B.; MONFARDINI, M. V.; VICENTINI, F.; KITAGAWA, S. S.; SCALETSKY, I. C. A.; SPANO, L. C. Genotypic and phenotypic analysis of diarrheagenic Escherichia coli strains isolated from brazilian children living in low socioeconomic level communities. BMC Infect Dis v. 13, N. 1, p. 418, 2013.

LOZER, D.; SOUZA, T. Genotypic and phenotypic analysis of diarrheagenic Escherichia coli strains isolated from Brazilian children living in low socioeconomic level communities. BMC Infect Dis v. 13, p. 418, 2013.

LUKÁŠ, F.; GORENC, G.; KOPEČNÝ, J. Detection of possible Al-2-mediated quorum sensing system in commensal intestinal bacteria. Folia Microbiol v. 53, p. 221-224, 2008.

LYAUTEY, E.; JACKSON, C. R.; CAYROU, J.; ROLS, J. L.; GARABETIAN, F. Bacterial community succession in natural river biofilm assemblages. Microb Ecol v. 50, p. 589-601, 2005.

LYON, W. R.; MADDEN, J. C.; LEVIN, J. C.; STEIN, J. L.; CAPARON, M. G. Mutation of luXS 
affects growth and virulence factor expression in Streptococcus pyogenes. Mol Microbiol v. 42 , p. 145-157, 2001.

LYTE, M.; ERICKSON, A. K.; ARULANANDAM, B. P.; FRANK, C. D.; CRAWFORD, M. A.; FRANCIS, D. H. Norepinephrine-induced expression of the K99 pilus adhesin of enterotoxigenic Escherichia coli. Biochem Biophys Res Commun v. 232, p. 682-686, 1997.

LYTE, M.; ERNST, S. Alpha and beta adrenergic receptor involvement in catecholamineinduced growth of Gram-negative bacteria. Biochem Biophys Res Commun v. 190, p. 447452, 1993.

LYTE, M. The role of microbial endocrinology in infectious disease. J Endocrin v. 137, p. 343-345, 1993.

LYTE, M. The role of catecholamines in Gram-negative sepsis. Med Hypotheses v. 37, p. 255-258, 1992.

MACFARLANE, G. T.; MACFARLANE, S. Human colonic microbiota: ecology, physiology and metabolic potential of intestinal bacteria. Scand J Gastroenterol Suppl v. 222, p. 3-9, 1997.

MAH, T. F.; O'TOOLE, G. A. Mechanisms of biofilm resistance to antimicrobial agents. Trends Microbiol v. 9, p. 34-39, 2001.

MAKINO, K.; OSHIMA, K.; KUROKAWA, K.; YOKOYAMA, K.; UDA, T.; TAGOMORI, K.; LIJIMA, Y.; NAJIMA, M.; NAKANO, M.; YAMASHITA, A.; KUBOTA, Y.; KIMURA, S.; YASUNAGA, T.; HONDA, T.; SHINAGAWA, H.; HATTORI, M.; LIDA, T. Genome sequence of Vibrio parahaemolyticus: a pathogenic mechanism distinct from that of $V$. cholerae. Lancet, v. 361, 743-749, 2003.

MARANHÃO, H. S.; MEDEIROS, M. C. C.; SCALETSKY, I. C. A.; FAGUNDES-NETO, U.; MORAIS, M. B. The epidemiological and clinical characteristics and nutritional development of infants with acute diarrhea, in northeastern Brazil. Ann Trop Med Parasitol v. 102, p. 357-365, 2008.

MAROUNI, M. J.; SELA, S. The luxS gene of Streptococcus pyogenes regulates expression of genes that affect internalization by epithelial cells. Infect Immun v. 71, p. 5633-5639, 2003.

MARQUES, M. do V. Biologia Molecular e Genética Bacteriana. 1 ed. Ribeirão Preto: Sociedade Brasileira de Genética, 348 p. 2012.

MARRIE, T. J.; NELLIGAN, J.; COSTERTON, J. W. A scanning and transmission electron microscopic study of and infected endocardial pacemaker lead. Circulation v. 66, p. 13391341, 1982.

MCDANIEL, T. K.; JARVIS, K. G.; DONNENBERG, M. S.; KAPER, J. B. A genetic locus of enterocyte effacement conserved among diverse enterobacterial pathogens. Proceed Nat Acad Sci v. 92, p. 1664-1668, 1995.

MELLIES, J. L.; BARRON, A. M.; CARMONA, A. M. Enteropathogenic and enterohemorrhagic Escherichia coli virulence gene regulation. Infect Immun v. 75, p. 4199210, 2007.

MICHAEL, B.; SMITH, J. N.; SWIFT, S.; HEFFRON, F.; AHMER, B. M. SdiA of Salmonella enterica is a LuxR homolog that detects mixed microbial communities. J Bacteriol v. 183, p. 
5733-5742, 2011.

MILLER, S. T.; XAVIER, K. B.; CAMPAGNA, S. R.; TAGA, M. E.; SEMMELHACK, M. F.; BASSLER, B. L.; HUGHSON, F. M. Salmonella typhimurium recognizes a chemically distinct form of the bacterial quorum-sensing signal Al-2. Mol Cell v. 15, p. 677-687, 2004.

MILLER, M. B.; SKORUPSKI, K.; LENZ, D. H.; TAYLOR, R. K.; BASSLER, B. L. Parallel quorum sensing systems converge to regulate virulence in Vibrio cholerae. Cell v. 110, p. 303-314, 2002.

MIYAMOTO, C. M.; LIN, Y. H.; MEIGHEN, E. A. Control of bioluminescence in Vibrio fischeri by the LuxO signal response regulator. Mol Microbiol v. 36, 594-607, 2000.

MOLINA, P. E. Endocrine physiology. M. H. Education Ed: Lange Medical Books/McGraw-Hill, 305 p, 2006.

MOON, H. W.; WHIPP, S. C.; ARGENZIO, R. A.; LEVINE, M. M.; GIANNELLA, R. A. Attaching and effacing activities of rabbit and human enteropathogenic Escherichia coli in pig and rabbit intestines. Infect Immun v. 41, p. 1340-1351, 1983.

MORATO, E. P.; LEOMIL, L.; BEUTIN, L.; KRAUSE, G.; MOURA, R. A.; PESTANA DE CASTRO, A. F. Domestic cats constitute a natural reservoir of human enteropathogenic Escherichia coli types. Zoonoses Public Health v. 56, p. 229-237, 2009.

MOREIRA, C. G.; PALMER, K.; WHITELEY, M.; SIRCILI, M. P.; TRABULSI, L. R.; CASTRO, A. F.; SPERANDIO, V. Bundle-forming pili and EspA are involved in biofilm formation by enteropathogenic Escherichia coli. J Bacteriol v. 188, 3952-3961, 2006.

MOREIRA, C. G.; CARNEIRO, S. M.; NATARO, J. P.; TRABULSI, L. R.; ELIAS, W. P. Role of type I fimbriae in the aggregative adhesion pattern of enteroaggregative Escherichia coli. FEMS Microbiol Lett v. 226, p. 79-85, 2003.

MORENO, A. C.; FILHO, A. F.; GOMES, T. A.; RAMOS, S. T.; MONTEMOR, L. P.; TAVARES, V. C.; FILHO, L. S.; IRINO, K.; MARTINEZ, M. B. Etiology of childhood diarrhea in the northeast of Brazil: significant emergent diarrheal pathogens. Diagn Microbiol Infect Dis v. 66, p. 50-57, 2010.

MORGAN, R.; KOHN, S.; HWANG, S. H.; HASSETT, D. J.; SAUER, K. BdIA, a chemotaxis regulator essential for biofilm dispersion in Pseudomonas aeruginosa. $\mathbf{J}$ bacteriol v. 188, $\mathrm{p}$. 7335-7343, 2006.

MOSBERG, J. A.; LAJOIE, M. J.; CHURCH, G. M. Lambda Red Recombineering in Escherichia coli Occurs Through a Fully Single-Stranded Intermediate. Genetics v. 186, p. 791-799, 2010.

MU, X. Q.; JIANG, Z. G.; BULLITT, E. Localization of a critical interface for helical rod formation of bacterial adhesion P-pili. J Mol Biol v. 346, p. 13-20, 2005.

NADELL, C. D.; BASSLER, B. L. A fitness trade-off between local competition and dispersal in Vibrio cholerae biofilms. Proceed Nat Acad Sci USA v. 108, p. 14181-14185, 2011.

NAKAZATO, G.; GYLES, C.; ZIEBELL, K.; KELLER, R.; TRABULSI, L.R.; GOMES, T.A.T.; IRINO, K.; SILVEIRA, W. D.; PESTANA DE CASTRO, A. F. Attaching and effacing Escherichia coli isolates from dogs in Brazil: characteristics and serotypic relationship to human Enteropathogenic E. coli (EPEC). Vet Microbiol v.101, p. 269-277, 2004. 
NAKHJAVANI, F. A.; EMANEINI, M.; HOSSEINI, H.; IMAN-EINI, H.; ALIGHOLI, M.; JABALAMELI, F.; HAGHI-ASHTIANI, M. T.; TAHERIKALANI, M.; MIRSALEHIAN. Molecular analysis of typical and atypical enteropathogenic Escherichia coli (EPEC) isolated from children with diarrhea. J Med Microb v. 62, p. 191-195, 2013.

NATARO, J. P.; KAPER, J. B. Diarrheagenic Escherichia coli. Clin Microbiol Rev v. 11, p. 142-201, 1998.

NAVES, P.; PRADO, G.; HUELVES, L.; GRACIA, M.; RUIZ, V.; BLANCO, J.; DAHBI, G.; BLANCO, M.; PONTE, M. C.; SORIANO, F. Correlation between virulence factors and in vitro biofilm formation by Escherichia coli strains. Microb Patho v. 45, p. 86-91, 2008.

NEALSON, K. H.; PLATT, T.; HASTINGS, J. W. Cellular control of the synthesis and activity of the bacterial luminescence system. J Bacteriol v. 104, p. 313-322, 1970.

NETER, E.; WEBB, C. R.; SHUMWAY, C. N.; MURDOCK, M. R. Study on Etiology, Epidemiology, and Antibiotic Therapy of Infantile Diarrhea, with Particular Reference to Certain Serotypes of Escherichia coli. American J Public Health v. 41, p. 1490-1496, 1951.

NIU, C.; ROBBINS, C. M.; PITTMAN, K. J.; OSBORN, J. L.; STUBBLEFIELD, B. A.; SIMMONS, R. B.; GILBERT, E. S. LuxS influences Escherichia coli biofilm formation through autoinducer-2-dependent and autoinducer-2-independent modalities. FEMS Microbiol Ecol v. 83, p. 778-791, 2013.

NG, W. L.; BASSLER, B. L. Bacterial quorum-sensing network architectures. Ann Rev Gen v. 43, p. 197-222, 2009.

NJOROGE, J. W.; NGUYEN, Y.; CURTIS, M. M.; MOREIRA, C. G.; SPERANDIO, V. Virulence meets metabolism: Cra and $\mathrm{KdpE}$ gene regulation in enterohemorrhagic Escherichia coli. MBio v. 3, e00280-12, 2012.

NJOROGE, J.; SPERANDIO, V. Enterohemorrhagic Escherichia coli virulence regulation by two bacterial adrenergic kinases, QseC and QseE. Infect Immun. v.80, p. 688-703, 2012.

NOVAK, E. A.; SHAO, H.; DAEP, C. A.; DEMUTH, D. R. Autoinducer-2 and QseC control biofilm formation and in vivo virulence of Aggregatibacter actinomycetemcomitans. Infect Immun v. 78, p. 2919-2926, 2010.

NUNES, M do R. C. M.; MAGALHÃES, P. P.; MACÊDO, SILVA, A. da. Attaching and effacing Escherichia coli and Shiga toxin-producing E. coli in children with acute diarrhoea and controls in Teresina/ PI, Brazil. Trans R Soc Trop Med Hyg v. 106, p. 43-47, 2012.

O'LOUGHLIN, C. T.; MILLER, L. C.; SIRYAPORN, A.; DRESCHER, K.; SEMMELHACK, M. F.; BASSLER, B. L. A quorum-sensing inhibitor blocks Pseudomonas aeruginosa virulence and biofilm formation. Proceed Nat Acad Sci v. 110, p. 17981-17986, 2013.

O'NEILL, J. Tackling Drug-Resistant Infections Globally: Final Report and Recommendations. The Review on Microbial Resistance, 2016.

O'TOOLE, G. A.; KOLTER, R. Flagellar and twitching motility are necessary for Pseudomonas aeruginosa biofilm development. Mol Microbiol v. 30, p. 295-304, 1998.

OCHOA, T. J.; ECKER, L.; BARLETTA, F.; MISPIRETA, M. L.; GIL, A. L.; CONTERAS, C.; MOLINA, M.; AMEMIYA, I.; VERASTEGUI, H.; HALL, E. R.; CLEARY, T. G.; LANATA, C. F. Age-related susceptibility to infection with diarrheagenic Escherichia coli among infants from 
periurban areas in Lima, Peru. Clin Infect Dis v. 49, p. 1694-1702, 2009.

OCHOA, T. J.; BARLETTA, F.; CONTRERAS, C.; MERCADO, E. New insights into the epidemiology of enteropathogenic Escherichia coli infection. Trans R Soc Trop Med Hyg v. 102, p. 852-856, 2008.

OLSÉN, A.; HERWALD, H.; WIKSTRÖM, M.; PERSSON, K.; MATTSON, E.; BJÖRCK, L. Identification of two protein-binding and functional regions of curli, a surface organelle and virulence determinant of Escherichia coli. J Biol Chem v. 227, p. 34568-34572, 2002.

OLSÉN, A.; ARNQVIST, A.; HAMMAR, M. R.; SUKUPOLVI, S.; NORMARK, S. The RpoS sigma factor relieves $\mathrm{H}-\mathrm{NS}$-mediated transcriptional repression of $\operatorname{csg} A$, the subunit gene of fibronectin-binding curli in Escherichia coli. Mol Microbiol v. 7, p. 523-536, 1993.

OLSEN, A.; ARNQVIST, A.; HAMMAR, M.; NORMARK, S. Environmental regulation of curli production in Escherichia coli. Infect Agen Dis v. 2, p. 272-274, 1993.

ÓLSEN, A.; JONSSON, A.; NORMARK, S. Fibronectin binding mediated by a novel class of surface organelles on Escherichia coli. Nature v. 338, p. 652-655, 1989.

ORLANDI, P. P.; MAGALHÃES, G. F.; MATOS, N. B.; SILVA, T.; PENATTI, M.; NOGUEIRA, P. A.; PEREIRA DA SILVA, L. H. Etiology of diarrheal infections in children of Porto Velho (Rondonia, Western Amazon region, Brazil). Brazil J Med Biol Res v. 39, p. 507-517, 2006.

ØRSKOV, F.; ØRSKOV, I. Serotyping of Escherichia coli. Methods Microbiol v. 14, p. 43$112,1984$.

OTERO, V.; RODRÍGUEZ-CALLEJA, J. M.; OTERO, A.; GARCÍA-LOPEZ, M. L.; SANTOS, J. A. Genetic characterization of atypical enteropathogenic Escherichia coli isolates from ewes' milk, sheep farm environments, and humans by multilocus sequence typing and pulsed-field gel electrophoresis. Appl Environ Microbiol v. 79, p. 5864-5869, 2013.

O'TOOLE, G. A.; GIBBS, K. A.; HAGER, P. W.; PHIBBS, P. V.; KOLTER, R. The global carbon metabolism regulator $\mathrm{Crc}$ is a component of a signal transduction pathway required for biofilm development by Pseudomonas aeruginosa. J Bacteriol v. 182, p. 425-431, 2000.

O'TOOLE, G. A.; KOLTER, R. Initiation of biofilm formation in Pseudomonas fluorescens WCS365 proceeds via multiple, convergent signalling pathways: a genetic analysis. Mol Microbiol v. 28, p. 449-461, 1998.

OTTOA, K.; ELWING, H.; HERMANSSON, M. The role of type 1 fimbriae in adhesion of Escherichia coli to hydrophilic and hydrophobic surfaces. Coll Surfaces B: Bioint v. 15, p. 99-111, 1999.

PACHECO, A. R.; SPERANDIO, V. Inter-kingdom signaling: chemical language between bacteria and host. Curr Opin Microbiol v. 12, p. 192-198, 2009.

PARKER, C. T.; SPERANDIO, V. Cell-to-cell signalling during pathogenesis. Cell Microbiol v. 11, p. 363-369, 2009.

PARSEK, M. R.; VAL, D. L.; HANZELKA, B. L.; CRONAN, J. E.; GREENBERG, E. P. Acyl homoserine-lactone quorum-sensing signal generation. Proceed Nat Acad Sci v. 96, p. 4360-4365, 1999.

PEARSON, J. P.; FELDMAN, M.; IGLEWSKI, B. H.; PRINCE, A. Pseudomonas aeruginosa cell-to-cell signaling is required for virulence in a model of acute pulmonary infection. Infect 
Immun v. 68, p. 4331-4334, 2000.

PELAYO, J. S.; SCALETSKY, I. C.; PEDROSO, M. Z.; SPERANDIO, V.; GIRÓN, J. A.; FRANKEL, G.; TRABULSI, L. R. Virulence properties of atypical EPEC strains. J Med Microbiol v. 48, p. 41-49, 1999.

PEREIRA, C. S.; THOMPSON, J. A.; XAVIER, K. B. Al-2-mediated signalling in bacteria. FEMS Microbiol Rev v. 37, p. 156-181, 2013.

PEREIRA, C. S.; DE REGT, A. K.; BRITO, P. H.; MILLER, S. T.; XAVIER, K. B. Identification of functional LsrB-like autoinducer-2 receptors. J Bacteriol v. 191, p. 6975-6987, 2009.

PEREIRA, C. S.; MCAULEY, J. R.; TAGA, M. E.; XAVIER, K. B.; MILLER, S. T. Sinorhizobium meliloti, a bacterium lacking the autoinducer-2 (Al-2) synthase, responds to Al-2 supplied by other bacteria. Mol Microbiol v. 70, p. 1223-1235, 2008.

PESCI, E. C.; MILBANK, J. B.; PEARSON, J. P.; MCKNIGHT, S.; KENDE, A. S.; GREENBERG, E. P.; IGLEWSKI, B. H. Quinolone signaling in the cell-to-cell communication system of Pseudomonas aeruginosa. Proc Natl Acad Sci v. 96, p. 11229-11234, 1999.

PETERS, G.; LOCCI, R.; PULVERER, G. Microbial colonization of prosthetic devices. II. Scanning electron microscopy of naturally infected intravenous catheters. Zentralb Bacteriol Mikrobiol Hyg v. 173, p. 293-299, 1981.

PETROVA, O. E.; SAUER, K. Sticky situations: key components that control bacterial surface attachment. J Bacteriol v. 194, p. 2413-2425, 2012.

PIRHONEN, M.; FLEGO, D.; HEIKINHEIMO, R.; PALVA, E. T. A small diffusible signal molecule is responsible for the global control of virulence and exoenzyme production in the plant pathogen Erwinia carotovora. EMBO J v. 12, p. 2467-2476, 1993.

PITONDO-SILVA, A.; NAKAZATO, G.; FALCÃO, J. P.; IRINO, K.; MARTINEZ, R.; DARINI, A. L. C.; HERNANDES, R. T. Phenotypic and genetic features of enteropathogenic Escherichia coli isolates from diarrheal children in the Ribeirão Preto metropolitan area, São Paulo State, Brazil. Apmis v. 123, p. 128-135, 2015.

POLLITT, E. J.; WEST, S. A.; CRUSZ, S. A.; BURTON-CHELLEW, M. N.; DIGGLE, S. P. Cooperation, quorum sensing and the evolution of virulence in Staphylococcus aureus. Infect Immun IAI-01216, 2013.

POVOLOTSKY, T. L.; HENGGE, R. 'Life-style' control networks in Escherichia coli: signaling by the second Messenger c-di-GMP. J Biotechnol v. 160, p. 10-16, 2012.

PRATT, L. A.; KOLTER, R. Genetic analysis of Escherichia coli biofilm formation: roles of flagella, motility, chemotaxis and type I pili. Mol Microbiol v. 30, p. 285-293, 1998.

PRICE, S. B.; WRIGHT, J. C.; DEGRAVES, F. J.; CASTANIE-CORNET, M. P.; FOSTER, J. W. Acid resistance systems required for survival of Escherichia coli O157:H7 in the bovine gastrointestinal tract and in apple cider are different. Appl Environ Microbiol v. 70, p. 47924799, 2004.

PRIGENT-COMBARET, C.; BROMBACHER, E.; VIDAL, O.; AMBERT, A.; LEJEUNE, P.; LANDINI, P.; DOREL, C. Complex regulatory network controls initial adhesion and biofilm formation in Escherichia coli via regulation of the $\operatorname{csg} D$ gene. J Bacteriol v. 183, p. 72137223, 2001. 
PRIGENT-COMBARET, C.; PRENSIER, G.; LETHI, T. T.; VIDAL, O.; LEJEUNE, P.; DOREL, C. Developmental pathway for biofilm formation in curli-producing Escherichia coli strains: role of flagella, curli and colanic acid. Environ Microbiol v. 2, p. 450-464, 2000.

PRIGENT-COMBARET, C.; VIDAL, O.; DOREL, C.; LEJEUNE, P. Abiotic Surface Sensing and Biofilm-Dependent Regulation of Gene Expression in Escherichia coli. J Bacteriol v. 181, p. 5993-6002, 1999.

RAHMATI, S.; YANG, S.; DAVIDSON, A. L.; ZECHIEDRICH, E. L. Control of the AcrAB multidrug efflux pump by quorum-sensing regulator SdiA. Mol Microbiol v. 43, p. 677-685, 2002.

RAMPERSAUD, A.; HARLOCKER, S.L.; INOUYE, M. The OmpR Protein of Escherichia coli Binds to Sites in the ompF Promoter Region in a Hierarchical Manner Determined by its Degree of Phosphorylation. J Biol Chem v. 269, p. 12559-12566, 1994.

RAPPAPORT, F.; HENIG, E. Media for the isolation and differenciation of pathogenic Escherichia coli (serotypes O111 and O55). J Clin Pathol v. 5, p. 361-362, 1952.

RASKO, D. A.; MOREIRA, C. G.; LI, D. R.; READING, N. C.; RITCHIE, J. M.; WALDOR, M. K.; WILLIAMS, N.; TAUSSIG, R.; WEI, S.; ROTH, M.; HUGHES, D. T.; HUNTLEY, J. F.; FINA, M. W.; FALCK, J. R.; HUGHES, D. T. Targeting QseC signaling and virulence for antibiotic development. Science v. 321, p. 1078-1080, 2008.

RASMUSSEN, B. Filamentous microfossils in a 3,235-million-year-old volcanogenic massive sulphide deposit. Nature v. 405, p. 676-679, 2000.

READING, N. C.; RASKO, D. A.; TORRES, A. G.; SPERANDIO, V. The two-component system QseEF and the membrane protein QseG link adrenergic and stress sensing to bacterial pathogenesis. Proceed Nat Acad Sci v. 106, p. 5889-5894, 2009.

REESER, R. J.; MEDLER, R. T.; BILLINGTON, S. J.; JOST, B. H.; JOENS, L. A. Characterization of Campylobacter jejuni biofilms under defined growth conditions. Appl Environ Microbiol v. 73, p. 1908-1913, 2007.

REICHENBACH, B.; GÖPEL, Y.; GÖRKE, B. Dual control by perfectly overlapping 654 -and $\sigma 70$-promoters adjusts small RNA GImY expression to different environmental signals. Mol Microbiol v. 74, p. 1054-1070, 2009.

REYSENBACH, A. L.; CADY, S. L. Microbiology of ancient and modern hydrothermal systems. Trends Microbiol v. 9, p. 79-86, 2001.

REZZONICO, F.; DUFFY, B. Lack of genomic evidence of Al-2 receptors suggests a nonquorum sensing role for luxS in most bacteria. BMC Microbiol v. 8, 154, 2008.

ROBINS-BROWNE R. M. Traditional enteropathogenic Escherichia coli of infantile diarrhoea. Rev Infect Dis v. 9, p. 28-53, 1987.

RODRIGUES, J.; THOMAZINI, C. M.; LOPES, C. A. M.; DANTAS, L. O. Concurrent Infection in a Dog and Colonization in a Child with a Human Enteropathogenic Escherichia coli Clone. J Clin Microbiol v. 42, p. 1388-1389, 2004.

RODRIGUES, J.; SCALETSKY, I. C. A.; CAMPOS, L. C.; GOMES, T. A. T.; WHITTAM, T. S.; TRABULSI, L. R. Clonal structure and virulence factors in strains of Escherichia coli of 
the classic serogroup O55. Infect Immun v.64, p. 2680-2686, 1996.

ROE, A. J.; TYSALL, L.; DRANSFIELD, T.; WANG, D.; FRASER-PITT, D.; MAHAJAN, A.; CONSTANDINOU, C.; INGLIS, N.; DOWNING, A.; TALBOT, R.; SMITH, D. G.; GALLY, D. L. Analysis of the expression, regulation and export of NleA-E in Escherichia coli O157:H7. Microbiol v. 153, p.1350-1360, 2007.

ROLLET, C.; GAL, L.; GUZZO, J. Biofilm-detached cells, a transition from a sessile to a planktonic phenotype: a comparative study of adhesion and physiological characteristics in Pseudomonas aeruginosa. FEMS Microbiol Letters v. 290, p. 135-142, 2008.

ROMLING, U. Molecular biology of cellulose production in bacteria. Res Microbiol v. 153, p. 205-212, 2002.

RÖMLING, U.; ROHDE, M.; OLSÉN, A.; NORMARK, S.; REINKÖSTER, J. AgfD, the checkpoint of multicellular and aggregative behaviour in Salmonella typhimurium regulates at least two independent pathways. Mol microbiol v. 36, p. 10-23, 2000.

RÖMLING, U.; SIERRALTA, W. D.; ERIKSSON, K.; NORMARK, S. Multicellular and aggregative behaviour of Salmonella typhimurium strains is controlled by mutations in the agfD promoter. Mol Microbiol v.28, p. 249-264, 1998.

ROTHBAUM, R.; MCADAMS, A. J.; GIANNELLA, R.; PARTIN, J. C. A clinicopathologic study of enterocyte-adherent Escherichia coli: a cause of protracted diarrhea in infants. Gastroenterol v. 83, p. 441-54, 1982.

SABAG-DAIGLE, A.; SOARES, J. A.; SMITH, J. N.; ELMASRY, M. E.; AHMER, B. M. The acyl homoserine lactone receptor, SdiA, of Escherichia coli and Salmonella enterica serovar Typhimurium does not respond to indole. Appl Environ Microbiol v. 78, p. 5424-5431, 2012.

SALTA, M.; WHARTON, J. A.; BLACHE, Y.; STOKES, K. R.; BRIAND, J. F. Marine biofilms on artificial surfaces: structure and dynamics. Environ Microbiol v. 15, p. 2879-2893, 2013.

SAMBROOK, J.; FRITSCH, E. F.; MANIATIS, T. Molecular Cloning: a Laboratory Manual. 2 ed; p. 1659, 1989.

SÁNCHEZ-SANMARTÍN, C.; BUSTAMANTE, V. H.; CALVA, E.; PUENTE, J. L. Transcriptional regulation of the orf19 gene and the tir-cesT-eae operon of enteropathogenic Escherichia coli. J Bacteriol v. 183, p. 2823-33, 2001.

SANDOZ, K. M.; MITZIMBERG, S. M.; SCHUSTER, M. Social cheating in Pseudomonas aeruginosa quorum sensing. Proceed Nat Acad Sci v. 104, p. 15876-15881, 2007.

SAUER, K. The genomics and proteomics of biofilm formation. Genome Biol v. 4, 219 p.; 2003.

SAUER, K.; CAMPER, A. K.; EHRLICH, G. D.; COSTERTON, J. W.; DAVIES, D.G. Pseudomonas aeruginosa displays multiple phenotypes during development as a biofilm. $\mathbf{J}$ Bacteriol v. 184, p. 1140-1154, 2002.

SCALETSKY, I. C. A.; ARANDA, K. R. S.; SOUZA, T. B.; SILVA, N. P.; MORAIS, M. B. Evidence of pathogenic subgroups among atypical enteropathogenic Escherichia coli strains. J Clin Microbiol v. 47, p. 3756-3759, 2009. 
SCALETSKY, I. C.; PEDROSO, M. Z.; OLIVA, C. A.; CARVALHO, R. L.; MORAIS, M. B.; FAGUNDES-NETO, U. A localized adherence-like pattern as a second pattern of adherence of classic enteropathogenic Escherichia coli to HEp-2 cells that is associated with infantile diarrhea. Infect Immun v. 67, p. 3410-3415, 1999.

SCALETSKY, I. C. A.; SILVA, M. L. M.; TRABULSI, L. R. Distinctive patterns of adherence of enteropathogenic Escherichia coli to HeLa cells. Infect Immun v. 45, p. 534-536, 1984.

SCHAUDER, S.; BASSLER, B. L. The languages of bacteria. Genes Dev v. 15, p. 14681480, 2001.

SCHAUDER, S.; SHOKAT, K.; SURETTE, M. G.; BASSLER, B. L. The LuxS family of bacterial autoinducers: biosynthesis of a novel quorum-sensing signal molecule. Mol Microbiol v. 41, p. 463-476, 2001.

SCHEUTZ, F.; CHEASTY, T.; WOODWARD, D.; SMITH, H. R. Designation of 0174 and O175 to temporary $\mathrm{O}$ groups $\mathrm{OX} 3$ and $\mathrm{OX7}$, and six new E. coli $\mathrm{O}$ groups that include verocytotoxin-producing E. coli (VTEC): O176, O177, O178, O179, O180 and O181. APMIS p. 569-584, 2004.

SCHNEIDER, R.; LOCKATELL, C. V.; JOHNSON, D.; BELAS, R. Detection and mutation of a luxS-encoded autoinducer in Proteus mirabilis. Microbiol v. 148, p. 773-782, 2002.

SCHUSTER, M.; JOSEPH SEXTON, D.; DIGGLE, S. P.; PETER GREENBERG, E. Acylhomoserine lactone quorum sensing: from evolution to application. Ann Rev Microbiol v. 67, p. 43-63, 2013.

SELA, S.; FRANK, S.; BELAUSOV, E.; PINTO, R. A mutation in the luxS gene influences Listeria monocytogenes biofilm formation. Appl Environ Microbiol v. 72, p. 5653-5658, 2006.

SHANKAR, M.; PONRAJ, P.; ILLAKKIAM, D.; RAJENDHRAN, J.; GUNASEKARAN, P. Inactivation of the transcriptional regulator-encoding gene sdiA enhances rice root colonization and biofilm formation in Enterobacter cloacae GS1. J Bacteriol v. 195, p. 3945, 2012.

SHAO, H.; LAMONT, R. J.; DEMUTH, D. R. Autoinducer 2 is required for biofilm growth of Aggregatibacter (Actinobacillus) actinomycetemcomitans. Infect Immun v. 75, p. 4211-4218, 2007.

SHARMA, V. K.; KUDVA, I. T.; BEARSON, B. L.; STASKO, J. A. Contributions of EspA filaments and Curli Fimbriae in cellular adherence and biofilm formation of enterohemorrhagic Escherichia coli O157:H7. PloS One v. 11, e0149745, 2016.

SHARMA, V. K.; BEARSON, S. M. D.; BEARSON, B. L. Evaluation of the effects of sdiA, a luxR homologue, on adherence and motility of Escherichia coli O157:H7. Microbiol v. $156 \mathrm{p}$. 1303-12, 2010.

SHEIKH, J.; HICKS, S.; DALL'AGNOL, M.; PHILLIPS, A. D.; NATARO, K. Roles for Fis and YafK in biofilm formation by enteroaggregative Escherichia coli. Mol Microbiol v. 41, p. 98397, 2001.

SHENG, H.; LIM, J. Y.; KNECHT, H. J.; LI, J.; HOVDE, C. J. Role of Escherichia coli O157:H7 virulence factors in colonization at the bovine terminal rectal mucosa. Infect Immun v. 74, p. 4685-4693, 2006. 
SHIMADA, T.; SHIMADA, K.; MATSUI, M.; KITAI, Y.; IGARASHI, J.; SUGA, H.; ISHIHAMA, A. Roles of cell division control factor SdiA: recognition of quorum sensing signals and modulation of transcription regulation targets. Genes Cells v. 19, p. 405-418, 2014.

SHROUT, J. D.; TOLKER-NIELSEN, T.; GIVSKOV, M.; PARSEK, M. R. The contribution of cell-cell signaling and motility to bacterial biofilm formation. MSR Bull v. 36, p. 367-373, 2011.

SIRCILI, M. P.; WALTERS, M.; TRABULSI, L. R.; SPERANDIO, V. Modulation of Enteropathogenic Escherichia coli Virulence by Quorum Sensing. Infect Immun v.72, p. 2329-2337, 2004.

SIRYAPORN, A.; GOULIAN, M. Cross-talk Suppression between the CpxA-CpxR and EnvZOmpR Two-Component Systems in E. coli. Mol0 Microbiol v. 70, p. 494-506, 2008.

SITNIKOV, D. M.; SCHINELLER, J. B.; BALDWIN, T. O. Control of cell division in Escherichia coli: regulation of transcription of ftsQA involves both rpoS and SdiA-mediated autoinduction. Proceed Nat Acad Sci v. 93, p. 336-341, 1996.

SMITH, D. R.; PRICE, J. E.; BURBY, P. E.; BLANCO, L. P.; CHAMBERLAIN, J.; CHAPMAN, M. R. The Production of Curli Amyloid Fibers Is Deeply Integrated into the Biology of Escherichia coli. Biomolecules v. 7, p. 75, 2017.

SMITH, D.; WANG, J. H.; SWATTON, J. E.; DAVENPORT, P.; PRICE, B.; MIKKELSEN, H.; WELCH, M. Variations on a theme: diverse $\mathrm{N}$-acyl homoserine lactone-mediated quorum sensing mechanisms in Gram-negative bacteria. Sci Progress v. 89, p. 167-211, 2006.

SMITH, J. N.; DYSZEL, J. L.; SOARES, J. A.; ELLERMEIER, C. D.; ALTIER, C.; LAWHON, S. D.; ADAMS, L. G.; KONJUFCA, V.; CURTISS, R.; SLAUCH, J. M.; AHMER, B. M. M. SdiA, an $\mathrm{N}$-acylhomoserine lactone receptor, becomes active during the transit of Salmonella enterica through the gastrointestinal tract of turtles. PLoS One v. 3, e2826, 2008.

SMITH, J. N.; AHMER, B. M. M. Detection of Other Microbial Species by Salmonella: Expression of the SdiA Regulon. J Bacteriol v. 185, p. 1357-1366, 2003.

SOUTHEY-PILLIG, C. J.; DAVIES, D. G.; SAUER, K. Characterization of temporal protein production in Pseudomonas aeruginosa biofilms. J Bacteriol v. 187, p. 8114-8126, 2005.

SPANO, L. C.; SADOVSKY, A. D. I.; SEGUI, P. N.; SAICK, K. W.; KITAGAWA, S. M. S.; PEREIRA, F. E. L.; FAGUNDES-NETO, U.; SCALETSKY, I. C. A. Age-specific prevalence of diffusely adherent Escherichia coli in Brazilian children with acute diarrhoea. $\mathbf{J}$ Med Microbiol v. 57, p. 359-363, 2008.

SPERANDIO, V. SdiA sensing of acyl-homoserine lactones by enterohemorrhagic E. coli (EHEC) serotype O157:H7 in the bovine rumen. Gut Microbes v. 1, p. 432-435, 2010.

SPERANDIO, V.; TORRES, A. G.; JARVIS, B.; NATARO, J. P.; KAPER, J. B. Bacteria-host communication: the language of hormones. Proceed Nat Acad Sci v. 100, p. 8951-8956, 2003.

SPERANDIO, V.; TORRES, A. G.; KAPER, J. B. Quorum sensing Escherichia coli regulators $B$ and $C$ (QseBC): a novel two-component regulatory system involved in the regulation of flagella and motility by quorum sensing in E. coli. Mol Microbiol v. 43, p. 809-821, 2002.

SPERANDIO, V.; TORRES, A. G.; GIRÓN, J. A.; KAPER, J. B. Quorum sensing is a global 
regulatory mechanism in enterohemorrhagic Escherichia coli O157: H7. J Bacteriol v. 183, p. 5187-5197, 2001.

SPERANDIO, V.; MELLIES, J. L.; NGUYEN, W.; SHIN, S.; KAPER, J. B. Quorum sensing controls expression of the type III secretion gene transcription and protein secretion in enterohemorrhagic and enteropathogenic Escherichia coli. Proc Natl Acad Sciv v. 96, p. 15196-15201, 1999.

STEVENS, A. M.; DOLAN, K. M.; GREENBERG, E. P. Synergistic binding of the Vibrio fischeri LuxR transcriptional activator domain and RNA polymerase to the lux promoter region. Proceed Nat Acad Sci v. 91, p. 12619-12623, 1994.

STEWART, P. S.; COSTERTON, J. W. Antibiotic resistance of bacteria in biofilms. Lancet v. 358, p. 135-138, 2001.

STEWART, G. S.; WILLIAMS, P. Lux genes and the applications of bacterial bioluminescence. Microbiol v. 138, p. 1289-1300, 1992.

STOODLEY, P.; SAUER, K.; DAVIES, D. G.; COSTERTON, J. W. Biofilms as complex differentiated communities. Annu Rev Microbiol v. 56, p. 187-209, 2002.

STOODLEY, P.; WILSON, S.; HALL-STOODLEY, L.; BOYLE, J. D.; LAPPIN-SCOTT, H. M.; COSTERTON, J. W. Growth and detachment of cell clusters from mature mixed-species biofilms. Appl Environ Microbiol v.67, p. 5608-5613, 2001.

SUN, J.; DANIEL, R.; WAGNER-DÖBLER, I.; ZENG, A. P. Is autoinducer-2 a universal signal for interspecies communication: a comparative genomic and phylogenetic analysis of the synthesis and signal transduction pathways. BMC Evol Biol v. 4, p. 36, 2004.

SURETTE, M. G.; MILLER, M. B.; BASSLER, B. L. Quorum sensing in Escherichia coli, Salmonella typhimurium, and Vibrio harveyi: a new family of genes responsible for autoinducer production. Proceed Nat Acad Sci v. 96, p. 1639-1644, 1999.

SWEM, L. R.; SWEM, D. L.; O'LOUGHLIN, C. T.; GATMAITAN, R.; ZHAO, B.; ULRICH, S. M.; BASSLER, B. L. A quorum-sensing antagonist targets both membrane-bound and cytoplasmic receptors and controls bacterial pathogenicity. Mol Cell v. 35, p. 143-153, 2009.

TAGA, M. E.; MILLER, S. T.; BASSLER, B. L. Lsr-mediated transport and processing of Al-2 in Salmonella typhimurium. Mol Microbiol v. 50, p. 1411-1427, 2003.

TAGA, M. E.; SEMMELHACK, J. L.; BASSLER, B. L. The LuxS-dependent autoinducer Al-2 controls the expression of an $A B C$ transporter that functions in Al-2 uptake in Salmonella typhimurium. Mol Microbiol v. 42, p. 777-793, 2001.

TAYLOR, M. W.; SCHUPP, P. J.; DAHLLOF, I.; KJELLEBERG, S.; STEINBERG, P. D. Host specificity in marine sponge-associated bacteria, and potential implications for marine microbial density. Environ Microbiol v. 6, p. 121-130, 2004.

TAYLOR, C. D.; WIRSEN, C. O.; GAILL, F. Rapid microbial production of filamentous sulfur mats at hydrothermal vents. Appl Environ Microbiol v. 65, p. 2253-2255, 1999.

TEIXEIRA, N. B.; ROJAS, T. C. G.; DA SILVEIRA, W. D.; MATHEUS-GUIMARÃES, C.; SILVA, N. P.; SCALETSKY, I. C. Genetic analysis of enteropathogenic Escherichia coli (EPEC) adherence factor (EAF) plasmid reveals a new deletion within the EAF probe sequence among O119 typical EPEC strains. BMC Microbiol v. 15, 2015. 
TELFORD, G.; WHEELER, D.; WILLIAMS, P.; TOMKINS, P. T.; APPLEBY, P.; SEWELL, H.; STEWART, G. S. A. B.; BYCROFT, B. W.; PRITCHARD, D. I. The Pseudomonas aeruginosa quorum-sensing signal molecule $\mathrm{N}$-(3-Oxododecanoyl)-I-Homoserine Lactone has immunomodulatory activity. Infect Immun v. 66, p. 36-42, 1998.

THOMPSON, J. A.; OLIVEIRA, R. A.; DJUKOVIC, A.; UBEDA, C.; XAVIER, K. B. Manipulation of the quorum sensing signal Al-2 affects the antibiotic-treated gut microbiota. Cell Reports v. 10, p. 1861-1871, 2015.

TOLKER-NIELSEN, T.; BRINCH, U. C.; RAGAS, P. C.; ANDERSEN, J. B.; JACOBSEN, C. S.; MOLIN, S. Development and dynamics of Pseudomonas sp. biofilms. J bacteriol v. 182, p. 6482-6489, 2000.

TOMASZ, A.; HOTCHKISS, R. D. Regulation of the transformability of pneumococcal cultures by macromolecular cell products. Proceed Nat Acad Sci v. 51, p. 480-487, 1964.

TORRES, A. G.; LÓPEZ-SÁNCHEZ, G. N.; MILFLORES-FLORES, L.; PATEL, S. D.; ROJAS-LÓPEZ, M.; MARTÍNEZ DE LA PEÑA, C. F.; ARENAS-HERNÁNDEZ, M. M.; MARTÍNEZ-LAGUNA, Y. Ler and H-NS, regulators controlling expression of the long polar fimbriae of Escherichia coli O157:H7. J Bacteriol v. 189, p. 5916-5928, 2007.

TORRES, A. G.; ZHOU, X.; KAPER, J. B. Adherence of diarrheagenic Escherichia coli strains to epithelial cells. Infect Immun v. 73, p. 18-29, 2005.

TRABULSI, L. R.; KELLER, R.; GOMES, T.A.T. Typical and atypical enteropathogenic Escherichia coli. Emerg Infect Dis v. 8, p. 508-513, 2002.

TUJULA, N. A.; HOLMSTROM, C.; MUSSMANN, M.; AMANN , R.; KJELLEBERG, S.; CROCETTI, G. R. A card-fish protocol for the identification and enumeration of epiphytic bacteria on marine algae. J Microbiol Methods v. 65, p. 604-607, 2006.

UDE, S.; ARNOLD, D. L.; MOON, C. D.; TIMMS-WILSON, T.; SPIERS, A. J. Biofilm formation and cellulose expression among diverse environmental Pseudomonas isolates. Environ Microbiol v. 8, p. 1997-2011, 2006.

UHLICH, G. A.; COOKE, P. H.; SOLOMON, E. B. Analyses of the Red-Dry-Roughphenotype of an Escherichia coli O157:H7 strain and its role in biofilm formation and resistance to antibacterial agents. Appl Environ Microb v. 72, p. 2564-2572, 2006.

VAL, D. L.; CRONAN, J. E. In vivo evidence that S-adenosylmethionine and fatty acid synthesis intermediates are the substrates for the Luxl family of autoinducer synthases. $\mathbf{J}$ Bacteriol v. 180, p. 2644-2651, 1998.

VAN HOUDT, R.; AERTSEN, A.; MOONS, P.; VANOIRBEEK, K.; MICHIELS, C. W. N-acylL-homoserine lactone signal interception by Escherichia coli. FEMS Microbiol Letters v. 256, p. 83-89, 2006.

VENDITTI, M.; BIAVASCO, F.; VARALDO, P. E.; MACCHIARELLI, A.; DE BIASE, L.; MARINO, B.; SERRA, P. Catheter-related endocarditis due to glycopeptide-resistant Enterococcus faecalis in a transplanted heart. Clin Infectious Dis v. 17, p. 524-525, 1993.

VENTER, J. C.; REMINGTON, K.; HEIDELBERG, J. F.; HALPERN, A. L.; RUSCH, D.; EISEN, J. A.; WU, D.; PAULSEN, I.; NELSON, K. E.; NELSON, W.; FOUTS, D. E.; LEVY, S.; KNAP, A. H.; LOMAS, M.W.; NEALSON, K.; WHITE, O.; PETERSON, J.; HOFFMAN, J.; PARSONS, R.; BADEN-TILLSON, H.; PFANNKOCH, C.; ROGERS, Y. H.; SMITH, H. O. 
Environmental genome shotgun sequencing of the Sargasso Sea. Science v. 304, p. 66-74, 2004.

VIDAL, O.; LONGIN, R.; PRIGENT-COMBARET, C.; DOREL, C.; HOOREMAN, M.; LEJEUNE, P. Isolation of an Escherichia coli K-12 mutant strain able to form biofilms on inert surfaces: involvement of a new ompR allele that increases curli expression. $\mathbf{J}$ Bacteriol $\mathbf{v}$. 180, p. 2442-2449, 1998.

VIEIRA, M.A.; ANDRADE, J.R.; TRABULSI, L.R.; ROSA, A.C.; DIAS, A.M.; RAMOS, S.R.; FRANKEL, G.; GOMES, T.A. Phenotypic and genotypic characteristics of Escherichia coli strains of non-enteropathogenic E. coli (EPEC) serogroups that carry EAE and lack the EPEC adherence factor and Shiga toxin DNA probe sequences. J Infect Dis v. 183, p. 76272, 2001.

Von BODMAN, S. B.; WILLEY, J. M.; DIGGLE, S. P. Cell-cell communication in bacteria: united we stand. J Bacteriol v. 190, p. 4377-4391, 2008.

VUONG, C.; VOYICH, J. M.; FISCHER, E.R.; BRAUGHTON, K. R.; WHITNEY, A. R.; DELEO, F. R.; OTTO, M. Polysaccharide intercellular adhesin (PIA) protects Staphylococcus epidermidis against major components of the human innate immune system. Cell Microbiol v. 6, p. 269-75, 2004.

WALTERS, M.; SIRCILI, M. P.; SPERANDIO, V. AI-3 synthesis is not dependent on luxS in Escherichia coli. J Bacteriol v. 188, p. 5668-5681, 2006.

WALTERS, M.; SPERANDIO, V. Quorum sensing in Escherichia coli and Salmonella. Intern J Med Microbiol v. 296, p. 125-131, 2006.

WANG, X.; ROCHON, M.; LAMPROKOSTOPOULOU, A.; LÜNSDORF, H.; NIMTZ, M.; RÖMLING, U. (2006). Impact of biofilm matrix components on interaction of commensal Escherichia coli with the gastrointestinal cell line HT-29. Cell Mol Life Sci, v. 63, p. 23522363, 2006.

WANG, X. D.; DE BOER, P. A.; ROTHFIELD, L. I. A factor that positively regulates cell division by activating transcription of the major cluster of essential cell division genes of Escherichia coli. EMBO J v. 10, p. 3363-3372, 1991.

WATNICK, P. I.; KOLTER, R. Steps in the development of a Vibrio cholerae El Tor Biofilm. Mol Microbiol v. 34, p. 586-595, 1999.

WEI, Y.; LEE, J. M.; SMULSKI, D. R.; LAROSSA, R. A. Global impact of sdiA amplification revealed by comprehensive gene expression profiling of Escherichia coli. J Bacteriol v. 183, p. 2265-2272, 2001.

WEISS-MUSZKAT, M.; SHAKH, D.; ZHOU, Y.; PINTO, R.; BELAUSOV, E.; CHAPMAN, M. R.; SELA, S. Biofilm Formation by and Multicellular Behavior of Escherichia coli O55:H7, an Atypical Enteropathogenic Strain. Appl Environ Microb v. 76, p. 1545-1554, 2010.

WESTALL, F.; DE WIT, M. J.; DANN, J.; VAN DER GAAST, S.; DE RONDE, C. E.; GERNEKE, D. Early archean fossil bacteria and biofilms in hydrothermally-influenced sediments from the Barbeton greenstone belt, South Africa. Precambrian Res v. 106, p. 93116, 2001.

WHITELEY, M.; LEE, K. M.; GREENBERG, E. P. Identification of genes controlled by quorum sensing in Pseudomonas aeruginosa. Proc Nat Acad Sci v. 96, p. 13904-13909, 1999. 
WILEY, R. H. The evolution of communication: information and manipulation. Anim Behav v.. 2, p. 156-189, 1983.

WILLIAMS, S. C.; PATTERSON, E. K.; CARTY, N. L.; GRISWOLD, J. A.; HAMOOD, A. N.; \& RUMBAUGH, K. P. Pseudomonas aeruginosa autoinducer enters and functions in mammalian cells. J Bacteriol v. 186, p. 2281-2287, 2004.

WINZER, K.; HARDIE, K. R.; BURGESS, N.; DOHERTY, N.; KIRKE, D.; HOLDEN, M. T.; LINFORTH, R.; CORNELL, K. A.; TAYLOR, A. J.; HILL, P. J.; WILLIAMS, P. LuXS: its role in central metabolism and the in vitro synthesis of 4-hydroxy-5-methyl-3 (2H)furanone. Microbiol v. 148, p. 909-922, 2002.

WINZER, K.; HARDIE, K. R.; WILLIAMS, P. Bacterial cell-to-cell communication: sorry, can't talk now-gone to lunch! Curr Opin Microbiol v. 5, p. 216-222, 2002.

WOLFE, A. J.; VISICK, K.L. Get the message out: cyclic-di-GMP regulates multiple levels of flagellum-based motility. J Bacteriol v. 190, p. 463-475, 2008.

WONG, A. R. C.; PEARSON, J. S.; BRIGHT, M. D.; MULNERA, D.; ROBINSON, K. S.; LEE, S. F.; FRANKEL, G.; HARTLAND, E. L. Enteropathogenic and enterohaemorrhagic Escherichia coli: even more subversive elements. Mol Microbiol v. 80, p. 1420-1438, 2011.

WORLD HEALTH ORGANIZATION. Antimicrobial Resistance: Global Report on surveillance. WHO GENEVA, 2014.

WORLD HEALTH ORGANIZATION. Diarrhoea: why children are still dying and what can be done. UNICEF/ World Health Organization, 58 p. 2009.

WORLD HEALTH ORGANIZATION. Program for control of diarrhoeal diseases. In: Manual for laboratory investigations of acute enteric infections. Genebra, World Health Organization, p. 113, 1987.

WU, Y.; OUTTEN, F. W. IscR controls iron-dependent biofilm formation in Escherichia coli by regulating type I fimbria expression. J Bacteriol v. 191, p. 1248-1257, 2009.

XAVIER, K. B.; BASSLER, B. L. Regulation of uptake and processing of the quorum-sensing autoinducer Al-2 in Escherichia coli. J Bacteriol v. 187, p. 238-248, 2005.

XAVIER, K. B.; BASSLER, B. L. LuxS quorum sensing: more than just a numbers game. Curr Opin Microbiol v. 6, p. 191-197, 2003.

XU, L.; LI, H.; VUONG, C.; VADYVALOO, V.; WANG, J.; YAO, Y.; OTTO, M.; GAO, Q. Role of the luxS quorum-sensing system in biofilm formation and virulence of Staphylococcus epidermidis. Infect Immun v. 74, 488-496, 2006.

XU, J.; GORDON, J. I. Inaugural article: honor thy symbionts. Proc Natl Acad Sci USA v. 100, p. 10452-10459, 2003.

XU, K. D.; MCFETERS, G. A.; STEWART, P. S. Biofilm resistance to antimicrobial agents. Microbiol v. 146, p. 547-549, 2000.

YERUSHALMI, G.; LITVAK, Y.; GUR-ARIE, L.; ROSENSHINE, I. Dynamics of expression and maturation of the type III secretion system of enteropathogenic Escherichia coli. $\mathbf{J}$ Bacteriol v. 196, p. 2798-2806, 2014. 
ZHANG, R. G.; PAPPAS, K. M.; BRACE, J. L.; MILLER, P. C.; OULMASSOV, T.; MOLYNEAUX, J. M.; JOACHIMIAK, A. Structure of a bacterial quorum-sensing transcription factor complexed with pheromone and DNA. Nature v. 417, p. 971, 2002.

ZHAO, K.; LIU, M.; BURGESS, R. R. Adaptation in Bacterial Flagellar and Motility Systems: From Regulon Members to Foraging-Like Behavior in E. coli. Nucl Acids Res v. 35, p. 4441-4452, 2007.

ZHU, C.; FENG, S.; SPERANDIO, V.; YANG, Z.; THATE, T. E.; KAPER, J. B.; BOEDEKER, E. C. The possible influence of LuxS in the in vivo virulence of rabbit enteropathogenic Escherichia coli. Vet Microbiol v. 125, p. 313-322, 2007.

ZOGAJ, X.; BOKRANZ, W.; NIMTZ, M.; RÖMLING, U. Production of Cellulose and Curli Fimbriae by Members of the Family Enterobacteriaceae Isolated from the Human Gastrointestinal Tract. Infect Immun v.71, p. 4151-4158, 2003.

ZOGAJ, X.; NIMTZ, M.; ROHDE, M.; BOKRANZ, W.; RÖMLING, U. The multicellular morphotypes of Salmonella typhimurium and Escherichia coli produce cellulose as the second component of the extracellular matrix. Mol Microbiol v. 39, p. 1452-1463, 2001. 